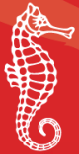

YEAR 14, No. 1, JUNE 2021, ISSN 2335-4194

\section{Academica Turistica}

Tourism \& Innovation Journal Revija za turizem in inovativnost

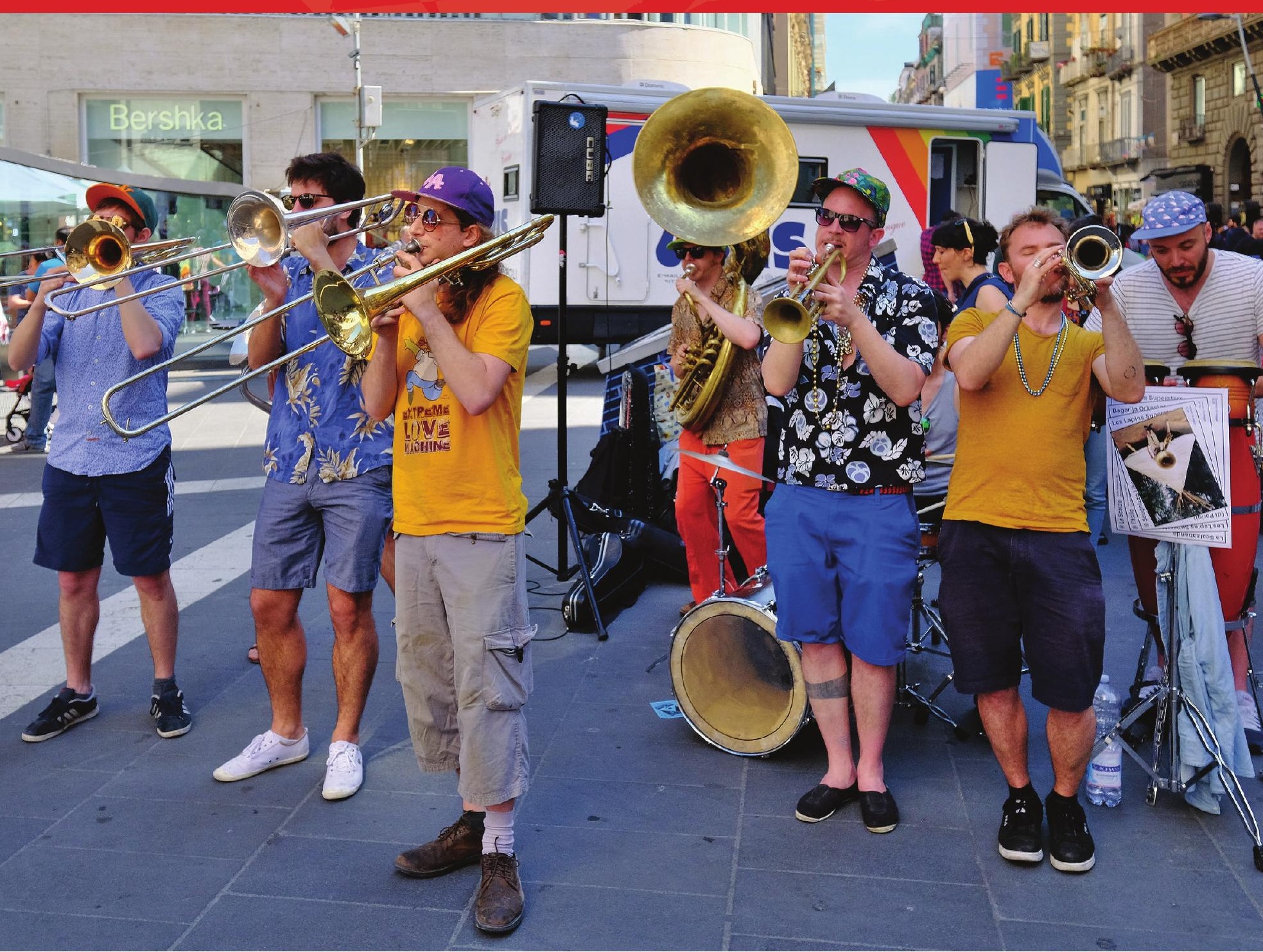





\section{Academica Turistica}

Tourism \& Innovation Journal - Revija za turizem in inovativnost

YEAR 14, No. 1, JUNE 2021, ISSN 2335-4194

https://doi.org/10.26493/2335-4194.14_1

3 Sustainable Tourism: Introduction to the Thematic Block

Ksenija Vodeb and Helena Nemec Rudež

7 Community Participation in Sustainable Valorisation of Cultural Heritage:

The Case of the Municipality of Vrsar

Kristina Afrić Rakitovac, Nataša Urošević, and Nikola Vojnović

23 Sustainable Development of an Island Tourist Destination: Example of the Island of Pag

Aleksandra Krajnović, Ivica Zdrilić, and Nikolina Miletić

39 A Destination's Social Sustainability: Linking Tourism Development

to Residents' Quality of Life

Emil Juvan, Eva Podovšovnik, Miha Lesjak, and Jasmina Jurgec

53 Managers' Perspectives about the Relationship between Tourism and Climate Change:

Case of the Republic of Croatia

Aleksandar Racz, Dora Smolčić Jurdana, and Zvonimira Šverko Grdić

71 A Study of Barriers to Environmentally Sustainable Practices in Hotel Businesses

in Punjab, India: Preliminary Findings

Baljit Kaur

87 Quality of a Rural Destination: Visitor and Resident Approach

Kateřina Mlejnková, Tomáš Dania, and Ida Rašovská

101 Willingness to Pay More: The Quest for Superstar Museums

Nuria Recuero Virto, María Francisca Blasco López, and Juan Antonio Mondejar

115 Abstracts in Slovene - Povzetki v slovenščini

119 Instructions for Authors

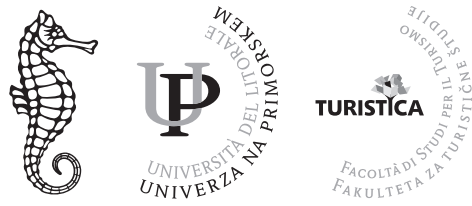

UNIVERSITY OF PRIMORSKA PRESS 
Executive Editor Marijana Sikošek

Editor-in-Chief Gorazd Sedmak

Associate Editors Metod Šuligoj, Emil Juvan, Helena Nemec Rudež, and Mitja Gorenak

Technical Editors Mariana Rodela and Peter Kopić

Production Editor Alen Ježovnik

\section{Editorial Board}

Rodolfo Baggio, University di Bocconi, Italy

Štefan Bojnec, University of Primorska, Slovenia

Dušan Borovčanin, Singidunum University, Serbia

Dimitrios Buhalis, Bournemouth University, UK

Célio Gonçalo Cardoso Marques, Polytechnic Institute of Tomar, Portugal

Frederic Dimanche, Ryerson University, Canada

Johan R. Edelheim, Hokkaido University, Japan

Doris Gomezelj Omerzel, University of Primorska, Slovenia

Sotiris Hji-Avgoustis, Ball State University, USA

Jafar Jafari, University of Wisconsin-Stout, USA,

University of Algarve, Portugal

Sandra Jankovič, University of Rijeka, Croatia

Sonja Sibila Lebe, University of Maribor, Slovenia

Sari Lenggogeni, Andalas University, Indonesia

Mara Manente, Ca' Foscari University of Venice, Italy

Yoel Mansfeld, University of Haifa, Israel

Tanja Mihalič, University of Ljubljana, Slovenia

Jasna Potočnik Topler, University of Maribor, Slovenia

Ljudevit Pranić, University of Split, Croatia

Hiroaki Saito, Ritsumeikan Asia Pacific University, Japan

Vinod Sasidharan, San Diego State University, USA

Marianna Sigala, University of South Australia

Marios Sotiriadis, Ningbo University, China

Mislav Šimunić, University of Rijeka, Croatia

Andreja Trdina, University of Maribor, Slovenia

Miroslav Vujičić, University of Novi Sad, Serbia

Suosheng Wang, Indiana University-Purdue

University Indianapolis, USA
Indexed in Scopus, Erih Plus, С A B Abstracts, CIRET, EBSCO, and EconPapers.

Published by University of Primorska Press University of Primorska

Titov trg 4, SI-60oo Koper

E-mail: zalozba@upr.si

Web: http://www.hippocampus.si

Editorial Office Academica Turistica

Faculty of Tourism Studies - Turistica

Obala 11a, sI-632o Portorož, Slovenia

E-mail: academica@turistica.si

Web: http://academica.turistica.si

Subscriptions The journal is distributed free of charge. For information about postage and packaging prices, please contact us at academica@turistica.si.

Copy Editor Terry Troy Jackson and Susan Cook Cover Design Mateja Oblak

Cover Photo Alen Ježovnik

Printed in Slovenia by Grafika 300o, Dob

Print Run 100 copies

Academica Turistica - Revija za turizem in inovativnost je znanstvena revija, namenjena mednarodni znanstveni in strokovni javnosti; izhaja $v$ angleščini s povzetki v slovenščini. Izid publikacije je finančno podprla Agencija za raziskovalno dejavnost Republike Slovenije iz sredstev državnega proračuna iz naslova razpisa za sofinanciranje domačih znanstvenih periodičnih publikacij.

IS SN 1855-3303 (printed)

ISSN 2335-4194 (online)

\section{(cc) BY-SA}




\title{
Sustainable Tourism: Introduction to the Thematic Block
}

\author{
Ksenija Vodeb \\ Guest Editor \\ University of Primorska, Faculty of Tourism Studies - Turistica, Slovenia \\ ksenija.vodeb@fts.upr.si \\ Helena Nemec Rudež \\ Guest Editor \\ University of Primorska, Faculty of Tourism Studies - Turistica, Slovenia \\ helena.nemec@fts.upr.si \\ (cc)BY-SA https://doi.org/10.26493/2335-4194.14.3-5
}

Despite three decades of active and intense discussion of tourism sustainability in academia and in tourism practice, recent references have shown that there is still much room for progress in this research area. At this very moment of a new milestone for tourism and society as a whole, new circumstances have arisen that change our understanding and suggest new choices that shift the concept of sustainable tourism as we have known it. The pandemic can be seen as one of the challenges, and it offers an opportunity to rethink our understanding of sustainable tourism (PerssonFischer \& Liu, 2021). But, even before the pandemic, it was clear that sustainable tourism, as a fluid and complex paradigm, urgently requires a systematic shift in comprehension. It therefore seems timely to review the progress of this tourism development concept and explore its possible future directions (Nunkoo \& Seetanah, 2019).

Sustainable tourism is now considered the dominant development paradigm in tourism research $(\mathrm{Ru}-$ hanen et al., 2015; Bramwell \& Lane, 2012), but it is rather inconstant and dynamic, which requires a precise, continuous and appropriate approach. Indeed, there is a plethora of relevant academic papers on this topic, providing valuable knowledge and understanding of the concept, as well as strategies and instruments for sustainable tourism implementation. An example of sustainable tourism indicators, designed by the World Economic Forum, is the Global Sustainable Competitiveness Index (GSCI), which was developed in 2012 as a subsection of the earlier well known and acknowledged Tourism and Travel Competitiveness Index ( $\mathrm{T} \mathrm{TCI}$ ). On the other hand, there still persists a critical gap between the theory and practice of sustainability in tourism. Moreover, the prevailing economic indicators used by the United Nations World Travel Organization (UNWTO) and many other tourism organisations (national, regional, and local), professionals and decision makers with a mindset that sustainability is merely an environmental issue, show how incomplete our knowledge and awareness of sustainable tourism is. Furthermore, recent social and technological changes in our society pose a great challenge and open new questions that need to be addressed and answered.

Ruhanen et al. (2019) investigated how research on sustainable tourism has evolved in the more than thirty years since the publication of the Brundtland report. They show that the field of research has matured over the past five years to the point where emphasis on climate change, modelling, values, behaviour and theoretical advancement in sustainable tourism have become important. Budeanu et al. (2015) pointed out the problem of low or even lack of criticality in sustainable tourism research and suggested the need for research contributions to improve adaptability to 
respond to and manage change under unpredictable circumstances. In a nutshell, they believe that the research conducted on this topic needs to be more effective in the future, and provide tourism practitioners with concrete solutions and tools. Additionally, they assigned to tourism sustainability the transformative power of the wider society due to its interrelationships with other spheres of human life and the economic sectors. They concluded that (p. 16) the academic world of tourism is a relatively small community and certainly one that is disproportionately tiny in relation to the size of the sector and its impacts. It would be necessary to bring additional academic capacity to the subject in order to achieve a strong outcome that could help to develop a solid ground for its development and progress.

Sharpley (2020) is very critical towards tourism and argues that its developmental role, unequal accessibility, degree of dependency, overconsumption and overproduction are the biggest challenges at the global level. The only solution he sees to reduce the use of fossil fuel in tourism in the future is to reduce air travel. Zhang and Chan (2020) problematised the vague conceptualisation of sustainable tourism and pointed it out as the reason for its ineffectiveness and underperformance in practice. They believe that sustainable development is a resource-concerned ethic, which should be concerned with resources and human needs in each specific context. Conversely, Streimikiene et al. (2021, p. 265) sound much more optimistic by concluding that competitiveness, environmental and social issues of sustainable tourism development can be addressed together by implementing innovations and fostering sustainable consumption principles. Providing innovative tourism services to tourists, achieving a competitive advantage by contributing to welfare, satisfying the needs of local communities, and addressing sustainable development priorities of tourism destinations are achievable goals.

Whether this shift in the current comprehension of sustainable development lies in the responsible behaviour and actions of stakeholders, or in the balanced performance of these actions and collaboration between stakeholders, sustainable tourism as it was defined and understood three decades ago is no longer relevant due to the maturation of the concept.

The collection of papers in this thematic block inspired by the above discussion brings together selected papers presented at the International Tourism Conference Encuentros 2020 - Sustainable Destinations: Walking the Sustainable Talk. To ensure an even more diverse selection of articles on sustainable tourism, the call for papers was disseminated to the wider research community after the conference. Afterwards, many interesting manuscripts were submitted for publication consideration, but the guest editors had to limit the number of papers selected in order to proceed with the publication process for the most theoretically and empirically high-quality papers.

This thematic block contains six articles authored by scholars from diverse geographic and research backgrounds addressing key issues in sustainable tourism: community participation, resident quality of life, ICM principles of an island destination, climate change, environmentally sustainable practices in hospitality and sustainable tourism competitiveness.

The first research paper, 'Community Participation in Sustainable Valorisation of Cultural Heritage: The Case of the Municipality of Vrsar' by Kristina Afrić Rakitovac, Nataša Urošević and Nikola Vojnović, illustrates the role of community participation as an essential principle of sustainable tourism. It explores the perspective of the local community in relation to the sustainable valorisation of cultural and archaeological heritage and finds that local stakeholders are interested in the sustainable development of cultural tourism that opposes the mass tourism that currently prevails. Furthermore, it confirms the aspiration of the community to be actively involved and informed in participatory models of heritage management. The findings of the research point to the need for knowledge capacity building and awareness raising among stakeholders and destination management in order to optimise the sustainable valorisation of heritage resources.

The example of sustainable development of an island destination based on IQM principles by Aleksandra Krajnović, Ivica Zdrilić and Nikolina Miletić explores its extent and factors influencing it on the Island of Pag among key tourism stakeholders. The research 
findings show unsatisfactory conditions of sustainable development due to mass tourism, extreme seasonality, excessive tourism construction and unbalanced development. The situation urgently calls for professional destination management.

The article titled 'A Destination's Social Sustainability: Linking Tourism Development to Residents' Quality of Life' by colleagues from Turistica, namely Emil Juvan, Eva Podovšovnik, Miha Lesjak and Jasmina Jurgec, examines residents' quality of life as a fundamental aspect of sustainable tourism development. The results show that interaction with tourists can play a more important role in life satisfaction than the level of tourism development. Besides this, the results indicate that neither the level of tourism development nor the interactions with tourists predict the life satisfaction of hosts and their emotional well-being. The authors highlight that achieving social sustainability is significantly context dependent and suggest a mixed methodological approach for further research, combining a quantitative and qualitative approach.

Tourism management beliefs and attitudes towards climate change are addressed by Aleksandar Racz, Dora Smolčić Jurdana and Zvonimira Šverko Grdić, colleagues from Croatia. They point out that significant change in sustainable development is possible by understanding attitudes and beliefs of managers in order to manage the risks and opportunities for change in unsustainable practices. The research findings have shown stronger pro-ecological attitudes and higher levels of ecological awareness regarding climate change among female managers, with tertiary education, greater professional experience and environmentally active individuals.

From the other side of the world comes 'A Study of Barriers of Environmentally Sustainable Practices in the Hotel Businesses in Punjab, India: Preliminary Findings' by Baljit Kaur, with the aim of exploring the barriers of environmentally sustainable practices (ESPS) in the area of hotel business. The issue of sustainability examined from the perspective of the hotel industry points to the need for information sharing and environmental awareness between policy makers and managers, changing conventional work practices, developing positive environmental attitudes, strict en- vironmental legislation, and involving top management in implementation strategies.

\section{References}

Bramwell, B., \& Lane, B. (2012). Towards innovation in sustainable tourism research? Journal of Sustainable Tourism, $20(1), 1-7$.

Budeanu, A., Miller, G., Moscardo, G., \& Ooi, C.-S. (2015). Sustainable tourism, progress, challenges and opportunities: Introduction. Journal of Cleaner Production, 111 (B), 285-540.

Nunkoo, R., \& Seetanah, B. (2019). Innovation in sustainable tourism. Tourism Review, 74(2), 129-292.

Persson-Fischer, U., \& Liu, S. (2021). The impact of a global crisis on areas and topics of tourism research. Sustainability, 13(2), 906. https://doi.org/10.339o/su13020906

Ruhanen, L., Weiler, B., Moyle, B. D., \& McLennan, C. J. (2015). Trends and patterns in sustainable tourism research: A 25-year bibliometric analysis. Journal of Sustainable Tourism, 23(4), 517-535.

Ruhanen, L., Moyle, C.-L., \& Moyle, B. (2019). New directions in sustainable tourism research. Tourism Review, $74(2), 138-149$.

Sharpley, R. (2020). Tourism, sustainable development and the theoretical divide: 20 years on, Journal of Sustainable Tourism, 28(11), 1932-1946.

Streimikiene, D., Svagzdiene, B., Jasinskas, E., \& Simanavicius, A. (2021). Sustainable tourism development and competitiveness: The systematic literature review. Sustainable Development, 29, 259-271.

Zhang, S., \& Chan, E. S. W. (2020). A modernism-based interpretation of sustainable tourism. International Journal of Tourism Research, 22, 223-237. 



\section{Community Participation in Sustainable Valorisation of Cultural Heritage: The Case of the Municipality of Vrsar}

\author{
Kristina Afrić Rakitovac \\ Juraj Dobrila University of Pula, \\ Croatia \\ kafric@unipu.hr \\ Nataša Urošević \\ Juraj Dobrila University of Pula, \\ Croatia \\ natasa.urosevic@unipu.hr
}

\author{
Nikola Vojnović \\ Juraj Dobrila University of Pula, \\ Croatia \\ nvojnov@unipu.hr
}

Sustainable tourism, as tourism that respects both residents and visitors, cultural heritage and the environment, can offer appropriate models for sustainable cultural heritage management and local economy development. Community participation is one of the fundamental principles of sustainable tourism. It was introduced in tourism studies more than three decades ago and elaborated through different methodological approaches and research. The purpose of this paper is to elaborate the local community perspectives regarding sustainable valorisation of cultural and archaeological heritage. The research was realised within the framework of ArchaeoCulTour, a recent scientific project whose main goal is to analyse the development potential of archaeological heritage through sustainable tourism in Istria County, Croatia. The research has considered the Municipality of Vrsar in Western Istria, a typical Mediterranean tourist destination, characterised by mass tourism and high seasonality, as a case study. The research has shown that the residents in the Municipality of Vrsar partially support the current tourism development model, faced with different sustainability challenges and many infrastructural problems. Residents are interested in being better informed and more involved in the tourism planning process and the participatory heritage management models. They agree that the main sustainability issues could be improved through sustainable valorisation of local cultural and natural resources by creating innovative tourism experiences, and they are interested to participate in this co-creating process.

Keywords: tourism destinations, cultural heritage, sustainable cultural tourism, community participation

(cc) BY-SA https://doi.org/10.26493/2335-4194.14.7-22

\section{Introduction}

Tourism destinations, as places with complex economic, urban and residential functions, are not passive locations for tourism activities, but dynamic systems and products of interactions between places and peo- ple, whose transformations depend on a combination of economic, social, political, cultural, historical and ecological factors. Therefore, tourism development planning and destination dynamics should consider all sustainability dimensions and involve all key stake- 
holders. The analysis of dynamic relationships that influence tourism development should explore tourism destinations as relational, intersectoral, collaborative, networked, hybrid, transnational and multiscalar systems.

The main goal of proper destination governance should be sustainable local development, the quality of life for the local community and a high-quality experience for tourists through networking and coordinating all key stakeholders. In order for a destination to be developed successfully, key stakeholders (public and private sectors, local community and tourists) should communicate, learn together, coordinate their development visions and share responsibility. The most challenging part of integrating all key stakeholders in destination governance is their active involvement in the planning process and implementation (Čorak, 2011). In this paper, the authors elaborate destination dynamics in heritage tourism through the participatory management model as one of the key principles of sustainable tourism. The concept is based on the four mutually interdependent pillars of sustainability: the social, economic, environmental and cultural pillars. Sustainable tourism should involve all relevant stakeholders in a tourism destination to recognise and valorise its specific, distinctive characteristics.

The dynamics between tourism destinations, natural and cultural resources and local stakeholders is the most important issue in sustainable tourism development. Since sustainable tourism is focused to benefit local residents, respect local culture, valorise local resources and educate tourists, as well as local residents, all activities and practices of sustainable tourism are directly connected to the four pillars of sustainable development. According to the UN World Tourism Organization (2016), tourism can be a powerful tool for community development and for reducing inequalities if it engages local populations and all key stakeholders in its development, in the framework of the 17 Sustainable Development Goals (SDG) of the 2030 Agenda for Sustainable Development. The local community should benefit from tourism and be actively involved in the tourism planning and heritage management process. Effective participation of local communities in heritage management, both in consultation and decision-making, is the main topic of some key strategic recommendations and conventions, such as the Faro Convention and the European Cultural Heritage Strategy for the 21st century, which work together as guides to social involvement, community collaboration and awareness-raising to ensure 'heritage for all' (Picard, 2017, p. 83).

Destination communities have also come together to resist, negotiate and/or co-create knowledge of their heritage tourism worlds. Heritage tourism knowledge production and distribution have increasingly been considered as collaborative, networked, political, transnational and multiscalar processes (Hollinshead, 1999; Ong et al., 2014; Winter, 2015).

The purpose of this paper is to present changing dynamics in a typical Mediterranean destination, with an emphasis on the role and attitudes of the local community in the collaborative processes of co-creating knowledge of the local cultural heritage. The research presented in this paper was conducted in the framework of the current scientific project 'The Archaeological Landscape in Sustainable Development of Cultural Tourism in Vrsar Municipality - ArchaeoCulTour.' The project is based on the collection, analysis and systematization of data on archaeological sites, and their use in strategic development of cultural tourism in the Municipality of Vrsar. Its objectives include the identification and analysis of archaeological heritage on the basis of field research, analysis of cartography, and aerial photographs; the preservation of archaeological heritage and landscape by continuous monitoring; the valorisation of archaeological heritage in the sustainable development context; an opinion survey among local residents, professionals and tourists on cultural, and in particular archaeological, heritage; the dissemination of the results for raising awareness of cultural tourism by creating new ways of presenting heritage; and the preparation of selected sites for presentation. The main aim of the project is to develop a successful strategy for sustainable growth of cultural tourism in Istria as the most developed Croatian tourist region, characterised by an abundance of archaeological sites, which are unfortunately still not adequately presented, interpreted and valorised.

The authors analysed the situation and the poten- 
tials for the sustainable valorisation of cultural and archaeological heritage in the Municipality of Vrsar in Western Istria, a typical Mediterranean tourist destination characterised by high seasonality, mass tourism concentrated on the coast, and inadequately valorised cultural heritage which is still not recognised as an important and valuable tourism resource. The authors combined qualitative and quantitative methodology which have involved all interested stakeholders (experts, the local community and visitors). The research was organised in three phases. The first phase, conducted in March 2018, included interviews and focus groups with 15 experts, with the aim of defining key issues and collecting information for situational analysis. The local community survey was conducted from March to May 2018, involving 200 inhabitants of Vrsar (with 182 properly completed questionnaires). The third phase of the research, conducted from May to September 2018, involved 820 tourists. In this paper, the authors present the results of the second phase related to attitudes and expectations of the local community regarding valorisation of local cultural heritage through sustainable cultural tourism.

In the next section, the authors elaborate the theoretical framework and literature review concerning the importance of community participation in sustainable valorisation of local cultural heritage. This is followed by a presentation of the results of empirical research related to the attitudes and expectations of the residents of the Municipality of Vrsar regarding the potentials of sustainable valorisation of local cultural heritage. The results are discussed in the concluding part of the paper.

\section{Conceptual Framework and Literature Review}

Sustainable tourism, as tourism that respects both local residents and visitors, the cultural heritage and the environment, can offer appropriate models for sustainable management of cultural heritage and local economy development at the same time. As Goodwin (2011) argues, there is not a unique blueprint for sustainable tourism. The challenges, priorities and solutions vary from place to place, depending on the level of economic development, social conditions, local culture and cultural heritage, environmental factors, nat- ural heritage, etc. From a destination perspective, the planning and implementation of sustainable tourism should involve and respect the long-term interests of all relevant stakeholders.

As Richards and Hall (2003) noted, sustaining local communities has become an essential element of sustainable tourism. If the resources of the host community are not managed in a responsible way, tourism development cannot be expected to be sustainable. On the other hand, sustainability of heritage resources cannot be achieved without the direct involvement of the local community: if heritage is respected, used and managed by the locals, it has better chances to be properly valorised. The rationale of sustainable tourism usually rests on providing long-term economic, social and cultural benefits to the community and its environment. A holistic approach to sustainability requires the continuing/improved social, cultural and economic well-being of human communities to be an integral component of environmental renewal. The balance between tourism development, sustainable valorisation of unique and valuable local resources and community well-being becomes a challenge in the modern world.

The concept of community participation was introduced to tourism studies more than three decades ago (Murphy, 1985 in Šegota et al., 2017). Informed stakeholders' participation and cooperation are some of the most important requirements for the implementation of sustainable tourism development (Mihalic, 2014). The advocates of participatory governance suggest that community participation can increase reliance and public consensus, lead to tourism strategies that correspond to local needs and contribute to destination sustainability (Byrd, Bosley and Dronberer, 2009; Currie, Seaton and Wesley, 2009). According to Gunn (1994) and supported by several studies (Ioannides, 1995; Robson \& Robson, 1996 in Šegota et al., 2017), sustainable tourism development cannot be successful without the support of citizens.

In this paper, the authors assumed that sustainable tourism, as tourism that respects both local residents and their visitors, the cultural heritage and the environment, could offer appropriate models for the sustainable management of cultural heritage and commu- 
nity development at the same time. It is supposed that cultural tourism, which 'cares for the culture it consumes while culturing the consumer' (Richards, 2007, p. 1), as a sustainable alternative to mass tourism, could strengthen the identity and economy of the local community, create new jobs, and increase the quality of life of local residents and a visitor's enjoyment, preserving the natural environment at the same time (Afrić Rakitovac \& Urošević, 2017).

Community participation in the development of sustainable cultural tourism is the main topic of many studies in the tourism field, which focus on the dynamics between tourism development, (un)sustainable use of key resources and local communities' reactions to its consequences (Zolfani et al., 2015). Terzić et al. (2014) have presented a methodology of cultural tourism sustainability indicators (including 30 indicators related to sustainability of heritage resource conservation, sustainability of tourism and tourismrelated sustainability of local community), elaborating studies (Xiang and Wall, 2005) which examined residents' attitudes towards tourism and the impacts tourism can have on a community (Perdue, Long and Allen, 1990; Ap, 1992; Lankford, 1994; Andereck \& Vogt, 2000; Gursoy, Jurowski and Uysal, 2002; McGehee \& Andereck, 2004; Andereck et al., 2005; Dyer et al., 2007; Wang \& Pfister, 2008; Anderleck \& Nyaupane, 2011). According to these authors, opinions and attitudes of local residents on the key values of cultural heritage and their tourist valorisation are important since they create a local perspective for evaluating possibilities to involve geographically limited territories into wider social, cultural and tourism flows.

Models of sustainable tourism development consider not only the aspects of the natural (physical) environment and economic impacts, but the sociocultural dimensions of destinations as well. The most important sociocultural effects of sustainable tourism are the mutual influences and impacts between local residents (community) and the broadest spectrum of tourism activities of a destination. There are numerous positive impacts in that relationship, such as increased local participation in destination activities and events, the strengthening of community values and the revival of traditions, greater security presence, the creation of new community space, exposure to new ideas through globalisation and transnationalism, etc. On the other hand, there are negative impacts such as changes in community structure, loss of authenticity, exceeding social carrying capacity, increases in criminal activity, etc. (Wall \& Mathieson, 2005; Hall \& Page, 2006; Hall, 2007). Despite the positive sociocultural effects of tourism development, the role of the local community in the sustainable tourism of destinations is neglected (Klarin, 2018). Furthermore, the satisfaction of local inhabitants with tourism development is associated with their involvement in tourism planning (Nunkoo \& Ramkissoon, 2010; Choi \& Murray, 2010).

Although scholars suggest and use various terms and phrases in order to explain participatory development strategies, in this research we used the concept of community participation in the tourism development process (СРTDP) which is defined as an adaptive and categorical (flexible) paradigm that allows local communities in various tourist destinations at different levels of development to participate in the decision-making process of tourism development, including sharing the benefits of tourism development, and determining the type and scale of tourism development in their localities (Tosun, 2000; 2005).

According to the analysed literature (Richards \& Munsters, 2010), the most appropriate methodological tools of scientific research of the CP TDP are questionnaires, participatory observation, focus groups and interviews. Recognising the geographical, developmental and economic specificities of the destination of Vrsar during the situational analysis at the beginning of the research, and the results of previous researches, the authors decided to use survey (questionnaire) methods to measure specific local destination dynamics. In scientific and professional publications in Croatia and abroad, there are numerous researches on local residents-tourism relationships and connections. The most important are those in which surveys, participatory observation, focus groups and interviews were used in order to consider the interconnections between local populations, including participatory models and the broadest aspects of tourism activities, especially in regions similar to the $\mathrm{Mu}$ nicipality of Vrsar. Such researches consider the so- 
cioeconomic and sociocultural impacts and transformations of tourism regions: Cape Cod (USA), Costa Blanca (Spain), Crete (Greece), Arizona (u s A), Victoria (Australia), the Slovenian Coast (Slovenia), Inland Istria, and the cities of Pula, Bjelovar and Čakovec (Croatia).

Among the earliest research on the interconnection of the local population and tourism activities and development was a study conducted in an attempt to empirically examine the existence of negative impacts of tourism. The local residents and the entrepreneurs of Cape Cod, Massachusetts, were interviewed to measure their perception of how tourism impacts the different domains of livelihood. Comparisons were made between the respondents' attitudes towards tourism and their dependence on tourism for a livelihood (Pizam, 1978). Research by Selwyn (1992) was to identify some of the reasons why tourism needs to be taken seriously by those concerned with community development both in the Third World and in Europe. The local political-economic issues and questions of tourism and the sociocultural change of destinations were considered.

Numerous researchers and scholars of tourism in the last two decades have considered the short- and long-term viability of the tourism business in receptive tourist regions. Rebollo and Baidal (2003) use an operative definition of sustainable tourism development that makes possible the effective application of its principles. From this basis, a system of sustainability indicators is developed that can be applied to Torrevieja, a Spanish Mediterranean destination that is notable for the size of its tourism industry and for its supply of holiday homes. The territorial and socioeconomic transformations that have resulted from Torrevieja's tourism development, along with the new local policies in response to these transformations, highlight both the contradictions and the chances of reconciling economic growth with sustainable development. A similar research by Andriotis and Vaughan (2007) focused on the identification and explanation of the attitudes of a sample of urban residents toward tourism development on Crete and their grouping with respect to these attitudes. Education and employment in tourism were found to be the major single factors af- fecting the attitudes of residents of the island of Crete. Andereck et al. (2007) investigated the differences between Hispanic and Anglo residents of the State of Arizona (USA) with respect to their perceptions of tourism and quality of life in terms of their ethnicity, framed with the context of ethnicity marginality theory.

A valuable contribution in terms of spatial planning of tourism activities of a destination was provided by the study in which researchers compare attitudes of locals towards tourism development in the Otways region of Victoria, Australia, using traditional survey research questions and a contemporary method for measuring spatial preferences for development (Raymond \& Brown, 2007). The results from the survey data showed conditional support for tourism growth and development in the Otway Hinterland and along the Otway Coast, irrespective of residence geographical distance from the centre of tourist activities.

Scientific research in the neighbouring regions similar to the Municipality of Vrsar are significant, too. Nemec Rudež and Vodeb (2010) considered the Slovenian coastal destinations of Koper and Piran using a questionnaire. The findings reveal that the residents' perceptions of tourism differ between municipalities which have different tourism concentrations. In fact, residents in the municipality with the higher tourism concentration perceive more negative tourism impacts, whilst, on the other hand, they do not perceive more positive tourism impacts. Vojnović (2013) examined the selected sociocultural characteristics of sustainable tourism in the nearest vicinity of Vrsar: inland Istria. The following sociocultural indicators of sustainable tourism were selected: the density of the registered and protected cultural and historical heritage relative to area size of towns and villages, the proportion of tourists who understand the language of the local population, the overall security measured as the ratio of criminal conducts and offenses of disturbing public order committed by tourists against the total number of such violations, the attitudes of the local population and accommodation owners towards tourism, as well as the attitudes of the municipal representatives. The attitudes of the local population and accommodation owners towards tourism were examined by adminis- 
tering the questionnaire which showed that tourism is an acceptable and desirable activity. In her analysis of the cultural tourism development potential of the city of Pula, Urošević (2012) analysed the perceptions and attitudes of the key stakeholders, including local residents, related to sustainable valorisation of the key local cultural resources, using questionnaires and interviews. The focus of Marković and FuerstBjelišs research (2015) is the identification of an individual with the spatial identity of a region and investigation of the effects on the sustainable development of tourism, based on a case study of the cities of Bjelovar and Čakovec in the Croatian Hinterland. The effects of tourism on the local community's quality of life are significant, which depends on the quality of a destination itself and on its sustainable development.

Šegota et al. (2017) considered the impact of residents' informedness and involvement on perception of tourism impact, taking the case of the destination Bled. The main research instrument was a selfadministered questionnaire. The finding of their study has shown that highly informed and highly involved residents had better perceptions of tourism's positive impacts than all other groups, whereas those residents who are poorly informed and weakly involved had more negative perceptions of tourism impacts than others.

The sustainability aspects which concern the local community, and which could be analysed include: decent livelihood opportunities; the number of tourism businesses owned and operated by the locals; local communities' share of profits from tourism; training of locals to acquire the competencies and skills for participating in heritage tourism; respect for local intellectual property; locals' accessibility to heritage as a tourism resource and use of tourism facilities; and the local community's participation in decision-making in relation to tourism development of heritage resource (involvement in the planning, research and decisionmaking process, community satisfaction with tourism practice and heritage conservation, etc.) (Xiang and Wall, 2005; Terzić at al., 2014).

In the next section, the authors present the results of empirical research related to the attitudes and expectations of the residents of the Municipality of Vrsar regarding the potentials of sustainable valorisation of local cultural heritage.

\section{Analysis of Local Population Attitudes and Expectations}

Research Methodology

Destination dynamics of Istria County, as Croatia's most developed tourist region, and the Municipality of Vrsar, as a typical Mediterranean destination, including a comparative analysis of the European and Croatian best practices regarding archaeological tourism, as well as the analysis of the first phase of the research which involved 15 experts through focus groups and interviews, are elaborated in previous research (Afrić Rakitovac et al., 2018).

The aim of the second phase of the conducted empirical research was to analyse the attitudes of the local population in the Municipality of Vrsar regarding sustainable valorisation of cultural and archaeological heritage.

The research involved the local community and was carried out on a sample of 182 inhabitants, i.e. 8.5\% of the total population in Vrsar (in 2015, there were 2,149 inhabitants). The research instrument was a questionnaire consisting of 15 questions, out of which three were closed questions, while twelve were openended questions. The questionnaire was previously tested on a sample of 30 inhabitants involved in a workshop organised as part of the project in April 2018. The final sample has embraced different groups of inhabitants from the local community (persons employed in the public sector and private companies, and members of civil organisations). The respondents' answers were collected by students as part of their practical education. The students were trained by the authors. The research was conducted in May 2018.

The research hypotheses of the empirical research were: (1): the local population supports tourism development in the Municipality of Vrsar; (2): the local population recognises potentials of cultural tourism development as a sustainable alternative to the current model of mass tourism; (3): the local population is not well informed about the archaeological heritage in the municipality as a potential for sustainable development or cultural tourism. 
Table 1 Sample Structure by Gender, Age, Level of Education, and Actual Position in the Labour Market

\begin{tabular}{|c|c|c|c|}
\hline Category & Item & $f$ & $f(\%)$ \\
\hline \multirow[t]{3}{*}{ Gender } & Male & 109 & 59.9 \\
\hline & Female & 73 & 40.1 \\
\hline & Total & 182 & 100.0 \\
\hline \multirow[t]{6}{*}{ Age } & $18-29$ & 21 & 11.5 \\
\hline & $30-39$ & 53 & 29.1 \\
\hline & $40-49$ & 62 & 34.1 \\
\hline & $50-59$ & 34 & 18.7 \\
\hline & $>60$ & 12 & 6.6 \\
\hline & Total & 182 & 100.0 \\
\hline \multirow[t]{5}{*}{ Level of education } & Elementary school & 3 & 1.6 \\
\hline & Secondary school & 90 & 49.5 \\
\hline & University & 71 & 39.0 \\
\hline & Master study & 18 & 9.9 \\
\hline & Total & 182 & 100.0 \\
\hline \multirow{6}{*}{$\begin{array}{l}\text { Actual position in } \\
\text { the labour market }\end{array}$} & Employed & 127 & 69.8 \\
\hline & Entrepreneur & 31 & 17.0 \\
\hline & Student & 3 & 1.6 \\
\hline & Retiree & 9 & 4.9 \\
\hline & Unemployed & 12 & 6.6 \\
\hline & Total & 182 & 100.0 \\
\hline
\end{tabular}

The paper presents selected questions and answers. The data have been analysed by methods of descriptive analysis and the one-way ANOVA analysis, processed by means of the SPSS programme 24.0.

\section{Sample Characteristics}

The characteristics of the sample are presented in Tables 1 and 2. There were $59.9 \%$ male and $40.1 \%$ female participants. Concerning the age structure, the largest was the age group from $40-49$, followed by those from 30-39, and the age group from 50-59. Regarding the levels of education, the largest group of respondents were those with a secondary school degree, followed by those with a university degree; together they comprise $88.5 \%$ of the sample. Concerning the actual position in the labour market, the majority of respondents (69.8\%) are currently employed, $17 \%$
Table 2 Sample Structure ba the Impact of Tourism Earnings on Household Income

\begin{tabular}{lrr}
\hline Options & $f$ & $f(\%)$ \\
\hline $\begin{array}{l}\text { Larger part of the household income is } \\
\text { realised through tourism-related activities }\end{array}$ & 102 & 56.0 \\
$\begin{array}{l}\text { Smaller part of the household income is } \\
\text { realised through tourism-related activities }\end{array}$ & 52 & 28.6 \\
$\begin{array}{l}\text { Household income is independent of } \\
\text { tourism-related activities }\end{array}$ & 28 & 15.4 \\
\hline Total & 182 & 100.0 \\
\hline
\end{tabular}

are entrepreneurs, $6.6 \%$ are unemployed, $4.9 \%$ are retired and $1.6 \%$ are students. Regarding the impact of tourism earnings on the respondents' household income, the majority of them (56.0\%) report that a large part of their household income is related to tourism activities, for $28.6 \%$ of them such impact is small, while for $15.4 \%$ of respondents their household income is not affected by tourism activities. We can conclude that the majority of the local population is engaged in tourism and dependent on tourism-related activities.

\section{Research Results}

The first part of the questionnaire explored the local population's attitudes towards the proposed statements related to the impacts of tourism on the local community. As indicated in Table 3, the local population was mainly satisfied with tourism development in the municipality (arithmetic mean on Likert's scale higher than 4). The respondents expressed the highest levels of agreement with the following statements: tourists are welcome regardless of their country of origin (4.68), tourism contributes to higher levels of employment in the Municipality of Vrsar (4.59), tourism is the most important economic activity in the municipality (4.47), tourism development benefits the majority of the population in Vrsar (4.47), and tourists' language(s) are not a barrier for communication (4.14). The respondents expressed the lowest levels of agreement regarding the possibilities of active participation of the local population in the tourism planning process (3.32), the contribution of tourism to environmental protection (3.45), and levels of satisfaction with cultural attractiveness in the municipality (3.24). 
Table 3 Local Population's Attitudes Regarding the Proposed Statements

\begin{tabular}{|c|c|c|c|c|c|c|c|c|}
\hline \multirow[t]{2}{*}{ Statements } & \multicolumn{5}{|c|}{ Frequencies } & \multirow[t]{2}{*}{ (1) } & \multirow[t]{2}{*}{ (2) } & \multirow[t]{2}{*}{ (3) } \\
\hline & 1 & 2 & 3 & 4 & 5 & & & \\
\hline Tourism contributes to higher employment in Vrsar & 1 & 4 & 5 & 49 & 123 & 4.59 & 0.706 & -2.177 \\
\hline Tourism is the most important economic activity in Vrsar & 1 & 3 & 11 & 62 & 105 & 4.47 & 0.733 & -1.586 \\
\hline Tourism develop. benefits the majority of the population in Vrsar & 1 & 7 & 8 & 56 & 110 & 4.47 & 0.798 & -1.770 \\
\hline Tourists do not hinder daily life and work in Vrsar & 8 & 23 & 50 & 55 & 46 & 3.59 & 1.127 & -0.434 \\
\hline I actively participate in the tourism planning process in Vrsar & 19 & 29 & 49 & 45 & 40 & $3 \cdot 32$ & 1.269 & -0.275 \\
\hline Tourism contributes to environmental protection in Vrsar & 9 & 22 & 64 & 52 & 35 & 3.45 & 1.085 & -0.291 \\
\hline Tourists' language(s) are not a barrier for communication & 2 & 9 & 20 & 81 & 70 & 4.14 & 0.880 & -1.119 \\
\hline Tourists are welcome regardless of the country of origin & 1 & 2 & 5 & 38 & 136 & 4.68 & 0.637 & -2.586 \\
\hline Tourists contribute to the pres. of customs and cult. heritage & 1 & 11 & 42 & 65 & 63 & 3.98 & 0.934 & -0.573 \\
\hline Estimate the level of satisfaction with the cultural offer in Vrsar & 13 & 36 & 59 & 43 & 31 & 3.24 & 1.163 & -0.089 \\
\hline
\end{tabular}

Notes Column headings are as follows: (1) arithmetic mean, (2) standard deviation, (3) skewness.

Table 4 Statistical Differences Related to the Local Population's Attitudes Regarding the Proposed Statements: Gender and Age (Mean Values)

\begin{tabular}{|c|c|c|c|c|c|c|c|c|c|c|c|}
\hline \multirow[t]{2}{*}{ Statements } & \multicolumn{4}{|c|}{ Gender } & \multicolumn{6}{|c|}{ Age } & \multirow[b]{2}{*}{$p$} \\
\hline & (1) & (2) & $P$ & $p$ & $18-29$ & $30-39$ & $40-49$ & $50-59$ & $>60$ & $P$ & \\
\hline $\begin{array}{l}\text { Tourism contributes to higher } \\
\text { employment in Vrsar }\end{array}$ & 4.62 & 4.53 & 0.704 & 0.403 & $4 \cdot 38$ & 4.53 & 4.56 & 4.79 & 4.75 & 1.463 & 0.216 \\
\hline $\begin{array}{l}\text { Tourism is the most important } \\
\text { economic activity in Vrsar }\end{array}$ & 4.42 & 4.53 & 1.024 & 0.313 & 4.48 & 4.19 & 4.56 & 4.74 & 4.42 & 3.523 & 0.009 \\
\hline $\begin{array}{l}\text { Tourism development benefits the } \\
\text { majority of the population } \\
\text { in Vrsar }\end{array}$ & 4.41 & 4.55 & 1.254 & 0.264 & 4.52 & 4.28 & 4.42 & 4.71 & 4.75 & 1.966 & 0.106 \\
\hline $\begin{array}{l}\text { Tourists do not hinder daily life } \\
\text { and work in Vrsar }\end{array}$ & 3.61 & 3.58 & 0.031 & 0.860 & 3.38 & $3 \cdot 34$ & 3.65 & 3.97 & 3.75 & 1.940 & 0.106 \\
\hline $\begin{array}{l}\text { I actively participate in the tourism } \\
\text { planning process in Vrsar }\end{array}$ & 3.17 & 3.53 & 3.567 & 0.061 & 2.76 & 3.21 & 3.45 & 3.59 & $3 \cdot 33$ & 1.691 & 0.154 \\
\hline $\begin{array}{l}\text { Tourism contributes to environ- } \\
\text { mental protection in Vrsar }\end{array}$ & 3.42 & 3.49 & 0.187 & 0.666 & 3.19 & 3.13 & 3.40 & 3.97 & 4.08 & 4.822 & 0.001 \\
\hline $\begin{array}{l}\text { Tourists' languages are not a bar- } \\
\text { rier for communication }\end{array}$ & 4.15 & 4.14 & 0.005 & 0.942 & 4.00 & 3.89 & 4.23 & 4.47 & 4.17 & 2.672 & 0.034 \\
\hline $\begin{array}{l}\text { Tourists are welcome regardless of } \\
\text { the country of origin }\end{array}$ & 4.68 & 4.68 & 0.004 & 0.950 & 4.81 & 4.53 & 4.60 & 4.88 & 5.00 & 2.969 & 0.021 \\
\hline $\begin{array}{l}\text { Tourists contribute to the preser- } \\
\text { vation of customs and cultural } \\
\text { heritage }\end{array}$ & 4.02 & 3.92 & 0.505 & 0.478 & 3.76 & 3.74 & 4.0 & 4.24 & 4.58 & 3.238 & 0.014 \\
\hline $\begin{array}{l}\text { Estimate the level of satisfaction } \\
\text { with the cultural offer in Vrsar }\end{array}$ & 3.17 & $3 \cdot 34$ & 1.016 & 0.315 & 3.05 & 3.06 & 3.24 & 3.41 & 3.83 & 1.534 & 0.218 \\
\hline
\end{tabular}

Notes Column headings are as follows: (1) female, (2) male. Tested by one-way A NovA. 
Table 5 Statistical Differences Related to the Local Population's Attitudes Regarding the Proposed Statements: Level of Education and Impact on Household Income (Mean Values)

\begin{tabular}{|c|c|c|c|c|c|c|c|c|c|c|c|}
\hline \multirow[t]{2}{*}{ Statements } & \multicolumn{6}{|c|}{ Level of education } & \multicolumn{5}{|c|}{ Impact on household income } \\
\hline & (1) & (2) & (3) & (4) & $P$ & $p$ & Large & Small & No & $P$ & $p$ \\
\hline $\begin{array}{l}\text { Tourism contributes to higher } \\
\text { employment in Vrsar }\end{array}$ & 2.67 & 4.64 & 4.58 & 4.67 & 8.665 & 0.000 & 4.73 & 4.62 & 4.04 & 11.817 & 0.000 \\
\hline $\begin{array}{l}\text { Tourism is the most important } \\
\text { economic activity in Vrsar }\end{array}$ & 2.67 & 4.57 & 4.45 & 4.33 & 7.530 & 0.000 & 4.60 & $4 \cdot 37$ & 4.18 & 4.459 & 0.013 \\
\hline $\begin{array}{l}\text { Tourism development benefits the } \\
\text { majority of the population } \\
\text { in Vrsar }\end{array}$ & 2.67 & 4.49 & 4.55 & 4.33 & 5.988 & 0.001 & 4.59 & 4.40 & 4.14 & 3.760 & 0.025 \\
\hline $\begin{array}{l}\text { Tourists do not hinder daily life } \\
\text { and work in Vrsar }\end{array}$ & 2.67 & 3.61 & 3.76 & 3.00 & 2.961 & 0.034 & 3.75 & 3.48 & 3.25 & 2.525 & 0.083 \\
\hline $\begin{array}{l}\text { I actively participate in the tourism } \\
\text { planning process in Vrsar }\end{array}$ & 3.00 & 3.29 & 3.46 & 2.94 & 0.914 & 0.436 & 3.62 & 2.92 & 2.96 & 6.866 & 0.001 \\
\hline $\begin{array}{l}\text { Tourism contributes to environ- } \\
\text { mental protection in Vrsar }\end{array}$ & 3.33 & 3.46 & 3.58 & 2.94 & 1.660 & 0.177 & 3.52 & 3.54 & 3.04 & 2.463 & 0.088 \\
\hline $\begin{array}{l}\text { Tourists' languages are not a bar- } \\
\text { rier for communication }\end{array}$ & 3.00 & 4.16 & 4.21 & 4.00 & 2.026 & 0.112 & 4.27 & 4.02 & 3.89 & 2.839 & 0.061 \\
\hline $\begin{array}{l}\text { Tourists are welcome regardless of } \\
\text { the country of origin }\end{array}$ & 2.67 & 4.77 & 4.72 & 4.44 & 13.882 & 0.000 & 4.73 & 4.69 & 4.50 & 1.392 & 0.251 \\
\hline $\begin{array}{l}\text { Tourists contribute to the preser- } \\
\text { vation of customs and cultural } \\
\text { heritage }\end{array}$ & 3.33 & 3.16 & 3.35 & 3.17 & 2.292 & 0.080 & 4.04 & 4.00 & 3.71 & 1.355 & 0.261 \\
\hline $\begin{array}{l}\text { Estimate the level of satisfaction } \\
\text { with the cultural offer in Vrsar }\end{array}$ & 2.67 & 3.94 & 4.04 & 4.11 & 0.404 & 0.751 & $3 \cdot 36$ & 3.19 & 2.86 & 2.155 & 0.119 \\
\hline
\end{tabular}

Notes Column headings are as follows: (1) elementary, (2) secondary, (3) university, (4) master. Tested by one-way A Nova.

The results presented in Table 3 were further analysed using the one-way ANOva analysis, as presented in Tables 4 and 5 . As indicated in Table 4, it can be concluded that there were not statistically significant differences in the respondents' answers according to gender, since all levels of significance are higher than $5 \%$ $(p<0.05)$. However, there were statistically significant differences according to the respondents' ages found for five statements: regarding tourism contribution to environmental protection $(p=0.001<0.05)$, regarding tourism as the most important economic activity in the municipality $(p=0.009<0.05)$, regarding the statement that tourists are welcome regardless of the country of origin $(p=0.021<0.05)$ and regarding tourists' language(s) not representing a barrier for communication $(p=0.034<0.05)$. Younger respon- dents are more sceptical regarding the positive impact of tourism on environmental protection and the impact of tourism on preservation of customs and cultural heritage.

As indicated in Table 5, there were statistically significant differences in relation to the respondents' levels of education found for five statements: regarding the contribution of tourism to higher employment rates in the municipality $(p<0.0,05)$, regarding tourism as the most important economic activity in $\operatorname{Vrsar}(p<0,05)$, regarding the statement that tourists are welcome regardless of the country of origin $(p<$ $0.05)$, regarding the statement that tourism development benefits the majority of the population $(p=0.001$ $<0.05$ ), and regarding the statement that tourists do not hinder daily life and work in the municipality. It 
Table 6 The Importance of Proposed Attractions of Vrsar as a Tourism Destination

\begin{tabular}{|c|c|c|c|c|c|c|c|c|}
\hline \multirow[t]{2}{*}{ Statements } & \multicolumn{5}{|c|}{ Frequencies } & \multirow[t]{2}{*}{ (1) } & \multirow[t]{2}{*}{ (2) } & \multirow[t]{2}{*}{ (3) } \\
\hline & 1 & 2 & 3 & 4 & 5 & & & \\
\hline The vicinity of the Adriatic sea & 1 & 1 & 10 & 50 & 120 & 4.58 & 0.675 & -1.865 \\
\hline The weather and the climate & o & 2 & 9 & 58 & 113 & 4.55 & 0.644 & -1.379 \\
\hline The coast and islands & 3 & 1 & 8 & 47 & 123 & 4.57 & 0.753 & -2.407 \\
\hline Natural and rare land cover type & 1 & 5 & 26 & 64 & 86 & 4.26 & 0.844 & -1.023 \\
\hline The Lim Channel & 1 & 3 & 8 & 56 & 114 & 4.53 & 0.710 & -1.848 \\
\hline Parks & 2 & 3 & 23 & 68 & 86 & 4.28 & 0.830 & -1.210 \\
\hline The Kontija Forest & 2 & 4 & 27 & 62 & 87 & 4.25 & 0.868 & -1.130 \\
\hline St. Michael's church & 2 & 10 & 50 & 60 & 60 & 3.91 & 0.959 & -0.506 \\
\hline Monte Ricco archaeological site & 5 & 9 & 43 & 68 & 57 & 3.90 & 0.995 & -0.777 \\
\hline Vrsar's mosaics & 5 & 15 & 44 & 51 & 67 & 3.88 & 1.086 & -0.674 \\
\hline St. Mary's of the Sea church & 1 & 5 & 34 & 70 & 72 & 4.14 & 0.853 & -0.754 \\
\hline Vrsar's old city centre & 2 & 3 & 22 & 55 & 100 & $4 \cdot 36$ & 0.841 & -1.389 \\
\hline Dušan Džamonja’s Park of Sculptures & 1 & 5 & 29 & 68 & 79 & 4.20 & 0.846 & -.0900 \\
\hline The culinary tradition & 4 & 7 & 35 & 69 & 67 & 4.03 & 0.957 & -0.946 \\
\hline Cultural, sports and entertainment manifestations & 6 & 9 & 30 & 63 & 74 & 4.04 & 1.034 & -1.088 \\
\hline
\end{tabular}

Notes Column headings are as follows: (1) arithmetic mean, (2) standard deviation, (3) skewness.

can be observed that the respondents with a higher level of education valuated tourism as an important economic and social phenomenon more frequently than those with a lower level of education.

As indicated in the same table, there were statistically significant differences regarding the impact of tourism on household income for four statements: regarding tourism contribution to higher employment rates in the Vrsar municipality $(p<0.0,05)$, regarding tourism as the most important economic activity in $\operatorname{Vrsar}(p<0,05)$, regarding the statement that tourism development benefits the majority of the population in $\operatorname{Vrsar}(p=0.001<0.05)$ and regarding active participation in the tourism planning process in Vrsar. It can be observed that tourism is considered as more important for respondents who have a larger impact of tourism on their household income. Consequently, those respondents are more interested in active participation in the tourism planning process.

Table 6 indicates the local population's perceptions of the proposed attractions of Vrsar as a tourism destination. As expected, considering the arithmetic mean scores on Likert's scale higher than 4, the local population has recognised the following as the most significant attributes: the Adriatic coast and nearby islands, the pleasant weather and climate, the Lim Channel, Vrsar's old city centre, etc. The local population considers the following as less attractive: Vrsar's mosaics, St. Michael's Church and the Monte Ricco archaeological site.

The following question was related to the perception of the local population about the most common tourist activities of tourists when visiting Vrsar (Table 7). As expected, considering the arithmetic mean scores on Likert's scale higher than 4 , the local population has recognised swimming and other seaside activities, visiting restaurants, walking trails and cycling as the most attractive activities for tourists. Less recognised were participation in the local community's activities, acquiring new experiences, visiting cultural and historical monuments, visiting cultural manifestations, visiting protected nature areas, and participation in sports and entertainment manifestations.

We can conclude that, according to the local popu- 
Table 7 Local Population's Perception of the Most Frequent Activities of Tourists Visiting Vrsar

\begin{tabular}{lrrrrrrrr}
\hline Statements & \multicolumn{3}{c}{ Frequencies } & & $(1)$ & $(2)$ & $(3)$ \\
\cline { 2 - 5 } & & 1 & 2 & 3 & 4 & 5 & & \\
\hline Swimming and other seaside activities & 1 & 2 & 21 & 61 & 97 & 4.38 & 0.775 & -1.206 \\
Visiting protected nature areas & 0 & 9 & 55 & 77 & 41 & 3.82 & 0.836 & -0.176 \\
Cycling & 1 & 2 & 33 & 90 & 56 & 4.09 & 0.760 & -0.607 \\
Visiting restaurants & 0 & 2 & 27 & 80 & 73 & 4.23 & 0.723 & -0.562 \\
Visiting cultural and historical monuments & 4 & 12 & 59 & 79 & 28 & 3.63 & 0.899 & -0.494 \\
Visiting cultural manifestations & & 10 & 58 & 73 & 41 & 3.80 & 0.852 & -0.138 \\
Participation in sports and entertainment manifestations & 2 & 5 & 48 & 78 & 49 & 3.92 & 0.860 & -0.526 \\
Participation in the local community's activities & 8 & 24 & 79 & 49 & 22 & 3.29 & 0.990 & -0.130 \\
Walking trails & 1 & 3 & 37 & 83 & 58 & 4.07 & 0.798 & -0.581 \\
New experiences & 6 & 17 & 69 & 56 & 34 & 3.52 & 1.007 & -0.274 \\
\hline
\end{tabular}

Notes Column headings are as follows: (1) arithmetic mean, (2) standard deviation, (3) skewness.

lation attitudes, tourists still perceive Vrsar as the sunand-sea destination for relaxing active holidays, complemented with enjoying the local food and recreation (swimming, cycling, walking) in beautiful nature.

The second part of the questionnaire consisted of ten open-ended questions aimed to determine the respondents' attitudes regarding the unique features and development potentials of Vrsar as a cultural tourism destination, as well as its greatest advantages and disadvantages. The respondents were asked about the most attractive cultural attractions and manifestations and about their habits when it comes to visiting cultural attractions and manifestations. They were also asked to propose ways for improving presentation of cultural and archaeological attractions, as well as the cultural tourism offer in general. In conclusion, they were asked about the results of the previous cultural tourism projects and expected results of the project ArchaeoCulTour. The results are presented in the swot matrix (Table 8).

When asked about the most recognisable and unique characteristics/attractions of Vrsar, the respondents emphasized the beauty of nature/archipelago/ sea ( $24.7 \%$ of respondents), and the unique cultural heritage symbolised by the romantic/picturesque old city core $(10.9 \%)$, as well as the importance of the first and biggest naturist camp in Europe - Koversada (10.9\%). The participants also mentioned the
Montraker quarry/sculpture school (5.5\%), the famous lover, Giacomo Casanova, who visited Vrsar twice (5.5\%), and the Lim Fjord (5.5\%) as important local brands.

The most frequent answers, regarding the five most attractive cultural and archaeological sites in the area of Vrsar, were: churches - St. Mary's (35.7\%), Dušan Džamonja's Park (27.4\%), the old castle with the city core (24.7\%), the Montraker quarry (16,5\%), Monte Ricco (10.9\%), the mosaics (8.2\%), etc.

The most frequent answers, regarding the five most attractive cultural and tourist manifestations in Vrsar, were: the fishermen fest (33.5\%) Casanovafest (26.4\%), the Old Fair (stari samanj) (19.8\%), concerts (16.5\%), the guitar festival (11.5\%), and the Montraker sculpture school (8.2\%).

When asked how Vrsar could present its cultural and archaeological attractions in a better way, the respondents offered the following answers: through mass media promotion/advertising/online marketing (16.5\%), manifestations (9.9\%), innovative interpretation models/guided tours (8.2\%), investment in infrastructure, founding a new cultural institution, and educating citizens $(2.7 \%)$, presentation through storytelling and themed products/routes (5.5\%), interactive interpretation centres $(2.7 \%)$, cooperation/inclusion of the local community $(8.2 \%)$, destination branding (2.7\%), etc. 
Table 8 swот Matrix on the Sustainable Development Potential of Cultural Heritage in the Municipality of Vrsar: Local Community Perspective

\section{Strengths}

- Favourable geographical position

- Proximity to emitive markets

- Favourable micro-climate

- Small, safe and quiet place

- Beautiful and preserved nature and environment

- Clean sea and nice beaches

- Best auto camps

- Proximity of the lime channel (protected natural area) and islands

- Preserved and rich cultural heritage (old city centre, churches, mosaics, sculpture garden, traditional gastronomy, archaeological sites, etc.)

- Active tourism (bikes, trail and trekking, climbing, kayaking, diving)

- Proximity of Marina Vrsar, one of the best nautical ports in croatia

Opportunities

- Connecting/networking the existing attractions into new routes and cultural itineraries

- Adequate presentation and interpretation of the rich cultural heritage

- Adequate presentation and interpretation of the rich cultural heritage

- Investment in the key cultural and natural resources (the old city core, Kontija, infrastructure), new festivals and manifestations

- Gastronomy

- Some specific cultural resources such as the mosaics

- Monterico, the Montraker quarry

- Džamonja's park and museum

- Churches

- New museums and interpretation centres, creative workshops, open-air theatre (Montraker),

- Diving at archaeological sites
Weakness

- Sun and sea tourism model

- Insufficient involvement of the local community in tourism planning and realisation of projects

- Insufficient valorisation of cultural heritage

- Cultural heritage is not recognised as a motive for choosing Vrsar as a tourism destination

- Lack of an institution for cultural and natural heritage management

- Insufficient sport facilities

- Insufficient entertainment facilities

Threats

- Competition of neighbouring tourism destinations with similar tourism concept based on sun and sea

- Decreased interest from tourists for the sea and sun tourism development model

- Climate changes
Regarding their usual visiting of cultural manifestations in Vrsar, 50\% of participants answered negatively, while another 50\% said they visit the following manifestations: the fishermen fest (15.9\%), the Old Fair (stari samanj) (12.6\%), Casanovafest (12.6\%), concerts (12.1\%), the guitar festival (4.9\%), the sculpture school (3.3\%), etc.

When asked if they have suggestions for improving the cultural tourism offer in Vrsar, the respondents mentioned the following: providing better information and promotion, reducing fishermen fests and creating events related to the most specific elements of the local identity, open-air museums, investing in the most important cultural resources (the old city core), improving signalisation and interpretation, as well as the quality of the cultural tourism offer, creating new cultural itineraries, educating tourist guides about local attractions, networking with similar European destinations, involving the local community in heritage valorisation and interpretation, applying for the $\mathrm{EU}$ projects and funds, etc.

Regarding their awareness about past cultural tourism projects in Vrsar, most of our respondents answered negatively, while only $20.9 \%$ of them mentioned some recent projects related to the new cycling routes, workshops and manifestations. As positive effects of such projects, they mentioned investments and better valorisation of cultural resources, a better image of Vrsar as a cultural tourism destination, raising awareness of local citizens about their heritage, the 
preservation of monuments and old traditions, extended tourist season, new segments of tourists, etc.

Concerning their awareness about the ArchaeoCulTour project, only $22.5 \%$ of respondents answered positively, while most of them were uninformed. What they expect from the project is better networking and coordination of key stakeholders, better media coverage, more satisfied tourists, better quality of cultural tourism offer, the preservation of cultural, natural and archaeological heritage, better presentation and innovative interpretation, extended tourist season, etc.

When asked if they had further suggestions, there were only 17 (9.3\%) positive answers, mostly related to innovations in the cultural tourism offer (new and more inclusive manifestations; new cultural infrastructure, suggestions related to the local infrastructure, signalisation and the role of the municipality in the project, giving a chance to young people and experts, etc).

\section{Discussion}

The research has shown that the local population in Vrsar is partially satisfied with the development of tourism in the municipality. The respondents have recognised the importance of tourism for the development of the local economy and increasing the living standards of the majority of the population. The research has shown that younger respondents are more sceptical regarding the positive impact of tourism on environmental protection and the impact of tourism on preservation of customs and cultural heritage. The respondents with a higher level of education valuated tourism as an important economic and social phenomenon more frequently than those with a lower level of education. In addition, tourism is considered as more important for respondents who have a larger impact of tourism on their household income. Although most of the local population is professionally engaged in tourism, they are not satisfied with the level of inclusion of residents in tourism planning and in heritage management.

According to local population attitudes, tourists still perceive Vrsar as the sun-and-sea destination for relaxing active holidays, complemented with enjoying the local food and recreation (swimming, cycling, walking) in beautiful nature. Although aware of the unique characteristics of the local natural and cultural heritage, as well as the good geographical position and proximity to emissive markets as the most valuable attractiveness factors, the respondents emphasized the neglect of the infrastructure, lack of quality cultural manifestations (which also explains the fact that only half of respondents visit the manifestations organised mostly during the summer season) and the need for better presented and interpreted cultural attractions as the main problems in the planning of sustainable cultural tourism. The research has shown that local residents are well informed about the main cultural resources and the possibilities of their sustainable valorisation through innovative interpretation models, such as cultural routes, living history, workshops which would include the local community, and interpretation centres. However, only a fifth of them were familiar with past cultural tourism projects implemented in the community, which indicates the need for better visibility and more active participation of the community in existing and future projects.

The results of the community survey are in line with the results of interviews and focus groups with experts organised in the first phase of the research. The authors expect the results of the tourist survey in the next stage would confirm some of the most important issues related to heritage management and sustainable cultural tourism development, as well as the need of capacity building and awareness raising about the local cultural heritage in the process of knowledge (co)creation.

\section{Conclusion}

The conducted research confirmed the main hypotheses: (1) the local population supports tourism development in the Municipality of Vrsar; (2) the local population recognises potentials of cultural tourism development as a sustainable alternative to the current model of mass tourism; (3) the local population is not well informed about the archaeological heritage in the Municipality as a potential for sustainable cultural tourism development.

Although the majority of the local residents (56\% of the sample) are directly employed in tourism, which 
would imply they mostly support tourism development, it is obvious that the community is saturated with the still prevailing model of mass sun-and-sea summer tourism, and that they are looking for a more sustainable model which would involve the locals in the tourism development and heritage management processes. The local residents are also very interested in presenting their local culture, traditions and heritage to their visitors, and they are actively engaged in proposing certain innovative models of sustainable preservation, valorisation and interpretation of the most recognizable cultural resources, such as heritage interpretation training.

Unlike the most recognisable cultural resources in the Municipality of Vrsar, the local community is still not aware of and adequately informed about the value of the local archaeological heritage and its potential for tourism valorisation, which indicates the need for innovative campaigns of awareness raising and capacity building. On the other hand, when asked, they suggested organising educative interactive workshops for the local community, networking and connecting heritage sites through cultural routes and educational paths, and interpretation centres for visitors. They also emphasized the lack of cultural manifestations and entertainment facilities, both for the locals and their visitors, as well as the need for investments in the cultural infrastructure.

The conducted research indicated that the local stakeholders are very interested in the sustainable development of cultural tourism as a sustainable alternative to the current model of mass tourism, and that they want to be involved in the tourism planning process, better informed and included in the participatory heritage management models. They agree that the main sustainability issues in the Municipality of Vrsar: high seasonality, mass tourism and infrastructure problems, could be resolved through sustainable valorisation of local cultural and natural resources by creating innovative tourism experiences, and they are interested in participating in this co-creating process.

The authors are aware of some limitations of the chosen methodology, which could not include or measure all dimensions of sustainability of cultural and tourism development. The comparative perspective would also be useful. Therefore, the authors expect that the results of the third and last phase of the research - the tourist survey, would allow a better insight into destination dynamics and more concrete proposals for innovations in the cultural tourism offer, and an adequate presentation and interpretation of the neglected archaeological heritage.

Since Vrsar represents the model of a typical coastal tourist destination in the Mediterranean, characterised by mass tourism and a remarkable seasonality, as well as huge potential for sustainable cultural tourism development through community involvement, the authors believe the final results and recommendations will be useful and applicable in the broader Euro-Mediterranean context. Research results confirm the need for capacity building and awareness raising among the key stakeholders about the local cultural heritage in the process of knowledge (co)creation and distribution in documented dynamic destination changes.

\section{Acknowledgments}

This work has been supported in part by the Croatian Science Foundation under the project PAR-2017-02-1.

\section{References}

Afrić Rakitovac, K., \& Urošević, N. (Eds.). (2017). Models of valorisation of cultural heritage in sustainable tourism. Juraj Dobrila University of Pula.

Afrić Rakitovac, K., Urošević, N., \& Vojnović, N. (2018). Project ArchaeoCulTour: Innovative valorization of archaeological heritage in Istria County through sustainable cultural and creative tourism. In V. Katsoni \& M. Segarra-Oña (Eds.), Smart tourism as a driver for culture and sustainability (pp. 61-77). Springer.

Andereck, K., \& Nyaupane, G. (2011). Exploring the nature of tourism and quality of life perceptions among residents. Journal of Travel Research, 50(3), 248-26o.

Andereck, K., \& Vogt, C. (200o). The relationship between residents' attitudes toward tourism and tourism development options. Journal of Travel Research, 39(August), 27-36.

Andereck, K., Valentine, K., Knopf, R., \& Vogt, C. (2005). Residents' perceptions of community tourism impacts. Annals of Tourism Research, 32(4), 1056-1076.

Andereck, K., Valentine, K., Vogt, C., \& Knopf, R. (2007). A cross-cultural analysis of tourism and quality of life 
perceptions. Journal of Sustainable Tourism, 15(5), 483502.

Andriotis, K., \& Vaughan, R. (2003). Urban residents' attitudes toward tourism development: The case of Crete. Journal of Travel Research, 42(2), 172-185.

Ap, J. (1992). Residents' perceptions of tourism impacts. Annals of Tourism Research, 19(4), 665-690.

Byrd, E. T., Bosley, H. E., \& Dronberger, M. G. (2009). Comparison of stakeholder perceptions of tourism in rural eastern North Carolina. Tourism Management, 30(5), 693-703.

Choi, H. C., \& Murray, I. (2010). Resident attitudes toward sustainable community tourism. Journal of Sustainable Tourism 18(4), 575-594.

Currie, R. R., Seaton, S., \& Wesley, F. (2009). Determining stakeholders for feasibility analysis. Annals of Tourism Research, 36(1), 41-63.

Čorak, S. (Ed.). (2011). Izazovi upravljanja turizmom. Institute for Tourism.

Dyer, P., Gursoy, D., Sharma, B., \& Carter, J. (2007). Structural modelling of resident perceptions of tourism and associated development on the Sunshine Coast, Australia. Tourism Management, 28(2), 409-422.

Goodwin, H. (2011). Taking responsibility for tourism. Goodfellow Publishers.

Gunn, C. A. (1994). Tourism planning: Basics, concepts, cases (3rd ed.). Taylor \& Francis.

Gursoy, D., Jurowski, C., \& Uysal, M. (2002). Resident attitudes: A structural modelling approach. Annals of Tourism Research, 29(1), 79-105.

Hall, C. M. (2007). Tourism planning: Policies, processes and relationships. Pearson Prentice Hall.

Hall, C. M., \& Page, S. (2006). The geography of tourism and recreation: Space, place and environment. Routledge.

Hollinshead, K. (1999). Surveillance of the worlds of tourism: Foucault and the eye-of-power. Tourism Management, 2o(1), 7-23.

Ioannides, D. (1995). A flawed implementation of sustainable tourism: The experience of Akamas, Cyprus. Tourism Management, 16(8), 583-592.

Klarin, T. (2018). Assumptions for a successful implementation of the concept of sustainable tourism development: Example of urban destinations of the Republic of Croatia. Acta Turistica, 30(1), 43-85.

Lankford, S. V. (1994). Attitudes and perceptions toward tourism and rural regional development. Journal of Travel Research, 32(2), 35-43.

Marković, I., \& Fuerst-Bjeliš, B. (2015). Spatial identity as a driving force in tourism development: Comparative analysis of the Bjelovar and Čakovec regions. Hrvatski geografski glasnik, 77(1), 71-80.

McGehee, N. G., \& Andereck, K. L. (2004). Factors predicting rural residents' support of tourism. Journal of Travel Research, 43(2), 131-140.

Mihalic, T. (2014). Sustainable-responsible tourism discourse: Towards 'response-sustainable' tourism. Journal of Cleaner Production, 111(Part B), 461-470.

Murphy, P. E. (1985). Tourism: A community approach. Methuen.

Nemec Rudež, H., \& Vodeb, K. (2010). Perceived tourism impacts in municipalities with different tourism concentration. Turizam, 58(2), 161-172.

Nunkoo, R., \& Ramkissoon, H. (2010). Small island urban tourism: A residents' perspective. Current Issues in Tourism, 13(1), 37-6o.

Ong, C. E., Ryan, C., \& McIntosh, A. (2014). Power-knowledge and tour-guide training: Capitalistic domination, utopian visions and the creation of UNESCo's HomoTurismos in Macao. Annals of Tourism Research, 48, 221234.

Perdue, R. R., Long, P. T., \& Allen, L. (1990). Resident support for tourism development. Annals of Tourism Research, 17(4), 586-599.

Picard, R. (2017). Heritage for all: The Council of Europe approach. Cartaditalia 1(2018 European Year of Cultural Heritage), 71-9o.

Pizam, A. (1978). Tourism's impacts: The social costs to the destination community as perceived by its residents. Journal of Travel Research, 16(8), 8-12.

Raymond, C., \& Brown, G. (2007). A spatial method for assessing resident and visitor attitudes towards tourism growth and development. Journal of Sustainable Tourism, 15(5), 520-540.

Rebollo, J. F. V., \& Baidal, J. A. I. (2003). Measuring sustainability in a mass tourist destination: Pressures, perceptions and policy responses in Torrevieja, Spain. Journal of Sustainable Tourism, 11(2-3), 181-203.

Richards, G. (Ed.) (2007). Cultural tourism: Global and local perspectives. The Haworth Hospitality Press.

Richards, G., \& Hall, D. (Eds.). (2003). Tourism and sustainable community development. Routledge.

Richards, G., \& Munster, W. (Eds.). (2010). Cultural tourism research methods. СА B $\mathrm{I}$.

Robson, J., \& Robson, I. (1996). From shareholders to stakeholders: Critical issues for tourism marketers. Tourism Management, 17(7), 533-540.

Selwyn, T. (1992). Tourism society and development. Community Development Journal, 27(4), 353-36o. 
Šegota, T., Mihalič, T., \& Kǔšcer, K. (2017). The impact of residents' informedness and involvement on perceptions of tourism impacts: The case of the destination Bled. Journal of Destination Marketing and Management, 6(3), 196206.

Terzić, A., Jovičić, A., \& Simeunović-Bajić, N. (2014). Community role in heritage management and sustainable tourism development: Case study of the Danube Region in Serbia. Transylvanian Review of Administrative Sciences (Special Issue), 183-201.

Tosun, C. (2000). Limits to community participation in the tourism development process in developing countries. Tourism Management, 21(6), 613-633.

Tosun, C. (2005). Stages in the emergence of a participatory tourism development approach in the developing world. Geoforum, 36(3), 333-352.

Urošević, N. (2012). Cultural identity and cultural tourism: Between the local and the global (A case study of Pula, Croatia). Singidunum Journal, 9(1), 67-76.

Vojnović, N. (2013). Socio-cultural characteristics of sustainable tourism in inland Istria. Socijalna ekologija, 22(2), 85-106.
Wall, G., \& Mathieson, A. (2005). Tourism: Change, impacts, opportunities. Pearson Education.

Wang, Y. A., \& Pfister, R. E. (2008). Residents' attitudes toward tourism and perceived personal benefits in a rural community. Journal of Travel Research, 47(1), 84-93.

Winter, T. (2015). Heritage diplomacy. International Journal of Heritage Studies, 21(10), 997-1015.

World Tourism Organization. (2016). A road map for celebrating together [Brochure].

Xiang, Y., \& Wall, G. (2005, August). Heritage conservation and local communities: Pressing issues in the developing countries [Paper presentation]. 3rd Sino-Korea International Tourism Conference, Weihai, China.

Zolfani, S., Sedaghat, M., Maknoon, R., \& Zavadskas, E. (2015). Sustainable tourism: A comprehensive literature review on frameworks and applications. Economic Research-Ekonomska istraživanja, 28(1), 1-30. 


\section{Sustainable Development of an Island Tourist Destination: Example of the Island of Pag}

\author{
Aleksandra Krajnović \\ University of Zadar, Department \\ of Economics, Croatia \\ akrajnov@unizd.hr
}

Ivica Zdrilić

University of Zadar, Department

of Economics, Croatia

izdrilic@unizd.hr

\author{
Nikolina Miletić \\ University of Zadar, Department \\ of Economics, Croatia \\ nikolina.miletic94@gmail.com
}

The purpose of this paper is to explore the issue of sustainable development of tourism in island destinations through the example of the island of Pag in Croatia. This paper aimed to find out the extent of sustainable tourism development on the island of Pag and to discover the factors influencing it. The primary research sought to determine what are the opinions and views of key tourism stakeholders about sustainable tourism on the island of Pag. The key research question in the paper is: Which model of tourism development is optimal for the sustainable development of the island of Pag as a tourist destination? The method of qualitative analysis was used, as well as primary research that combined interviews with experts and surveys. Furthermore, a comparative analysis of the research results has been performed using interviews and survey results. The research took place during 2019 on the island of Pag. Key stakeholders of tourism on the island of Pag were interviewed, as well as an employee of the Tourist Board of the City of Pag. According to the empirical research, it was found that sustainable tourism is developing poorly on the island of Pag. Sustainable tourism development implies responsible management of the area, with an emphasis on natural and cultural heritage, and aims to meet the needs of tourists and needs of current and future local communities. Sustainability and sustainable development of tourism, especially in the islands as extremely fragile geographical, economic, and socio-cultural entities, are of particular importance. In doing so, it is necessary to apply an integrated approach.

Keywords: sustainable tourism, mass tourism, sustainable tourist destination, seasonability, sustainable tourism on islands, the island of Pag

(cc)BY-SA https://doi.org/10.26493/2335-4194.14.23-37

\section{Introduction}

Sustainable tourism presents one of the major challenges when it comes to the social-economic and sociocultural development of each country and region focused on the development of tourism. However, this term, so often mentioned in real life and presented in strategic development plans, often remains at the level of the formal principle, since its application encounters numerous difficulties. Sunara et al. (2013, p. 83) considered that 'although sustainability is one of 
the most common concepts in tourism, a problem occurs when it is applied in real life.' The same authors state that the concept of sustainable development is based on meeting the needs not only of the present but also the future generation. 'It is important for a tourist destination to come up with a unique tourist offer that will meet the needs of tourists, without producing any negative impact on the environment, but rather govern the protection and sustainability of all tourism resources' (Sunara et al., 2013, p. 84).

The main sustainability challenges occur precisely at the local level, where different, often conflicting, interests arise when it comes to a tourist destination. Therefore, in this paper, the island of Pag in Croatia was taken as a specific example of a rapidly developing tourist destination on which to test the sustainability, or, respectively. sustainable development of tourism.

The purpose of this paper is to explore the issue of sustainability and sustainable development of tourism in island destinations. The primary research sought to determine what are the opinions and views of key tourism stakeholders about tourism on the island of Pag and about the level reached and key problems in the development of island tourism on Pag. The research questions posed in this paper are: What is sustainable tourism, and what is its significance in the development of tourism on islands? What are the goals of sustainable tourism, and how are they related to strategic planning in a tourist destination, based on the principles of an integrated approach to management? What are the geographical characteristics of the island of Pag, and what are the specifics of the development of tourism on the island? To what extent does the island of Pag care about the sustainable development of tourism? Which of the three key principles of sustainability - economic, socio-cultural, and environmental - do tourism stakeholders value the most when it comes to sustainable tourism? How important is it for the development of sustainable tourism to unite the brand of the island as a recognizable tourist destination?

The paper presents the results of the primary research performed by the method of a combination of expert interviews and surveys. Then, a comparative analysis of the research results was performed using interviews and survey results. The research was conducted in 2019 on the island of Pag in Croatia. Key stakeholders of tourism on the island of Pag were interviewed, as well as an employee of the Tourist Board of the City of Pag.

By researching the relevant literature, a research gap can be noticed when it comes to the development of tourism on the islands, especially when it comes to the Adriatic islands with their specifics. More comprehensive research that holistically looks at the issue of sustainable island tourism in the Adriatic dates back to twenty or even thirty years ago (see, for example, Mikačić, 1994; Vlahović, 2001). When it comes to foreign literature, the theory offers interesting case study analyses, such as Tioman Island, Malaysia ( $\mathrm{Ng}$ et al., 2017); Lakshadweep archipelago, India (Kokkranikal et al., 2003); the Island of Dominica (Lambert, 2009); Cat Ba Island, Vietnam (Mai \& Smith, 2015) and others. An interesting study is presented in the book Island Tourism and Sustainable Development: Caribbean, Pacific, and Mediterranean Experiences edited by Apostolopoulos and Gayle (2002), that highlights the key problems of sustainable island tourism based on the experiences of the Caribbean, Pacific, and Mediterranean islands. The same authors, in the introductory part of the book, point out that, 'as tourism is undoubtedly a vital component of the Caribbean, Pacific, and Mediterranean insular regions, our understanding of the ways it operates in the complex context of development is quite limited' (p. 12). A well-known theorist Cohen (2017, p. 7) speaks about a similar research gap, stating: 'Island studies and tourism studies have overlapping interests, but there was little interaction between them. [...] It is suggested that greater attention to this issue might be a facilitating factor in the convergence of island studies and tourism studies.' This paper was also written as a contribution to the research of these related phenomena - island studies and understanding the sustainability of island tourism.

\section{Sustainable Development of Island Tourism: Literature Review}

Čavlek \& Vukonić (2001) state that sustainable tourism is the ability of a tourist destination to remain bal- 
anced with the environment, i.e. the ability to remain competitive in the market despite the emergence of new and less-visited destinations and to attract both returning and first-time visitors, thus achieving enviable economic results while protecting and enhancing natural resources. Back in 1969, Becker noted that small islands exert a powerful attraction on tourists; their characteristic 'gestalt of remoteness, difference, distance, distinct culture and heritage, wilderness environment, and small size [constitutes] an attraction' (Brown \& Cave, 2010, in Cohen, 2017, p. 8). On the necessity of a holistic approach to researching the problems of island tourism development, Lim and Cooper (2008, p. 89) state that it is important to answer the question: 'How a complex and dynamic tourism system can be developed that takes a destination towards an optimal sustainable state to satisfy both visitors and the local community.'

One of the key research questions in this paper was whether tourism stakeholders believe that sustainable tourism should develop more on an economic, sociocultural, or environmental basis. A similar approach is taken by the editors of the book Island Tourism: Towards a Sustainable Perspective, Carlsen and Butler (2011), who structured the book according to these three principles. They point to the growing interest in research on sustainable island tourism development and state that the probable reason for this is 'the fact that islands form perfect "living laboratories" that enable researchers to isolate the causal and immediate effects of tourism development on the community, environment and economy of islands, and to study them at a level of detail that is not possible in other tourism destinations' (Carslen \& Butler, 2011, p. xii). Among earlier authors, we should point out the thesis of the Mikačić, who in her 1994 work emphasizes the essence of the issue of sustainable tourism on the Croatian islands, stating: 'Tourist facilities on the islands account for one-fourth of the overall Adriatic tourist offer. [...] Although its development has generally followed the coastal one, it took a more modest form so that the islands escaped many negative effects of mass tourism. In order to retain the existing advantages, the islands' development has to be harmonized with the environment while qualitative factors have to be given priority' (Mikačić, 1994, p. 517). Vlahović (2001, p. 229) states: 'On the islands, it is necessary to have long-term development programs, which automatically include the elaboration from spatial plans to the elaboration of implementing spatial plans in individual narrower tourist locations and zones.' Advocating for an integrated approach to management, or, as the author himself defines: 'measures and actions for holistic and more harmonious development ("integrated development"), he defines island resources as a 'wealth of nature and culture' and concludes: 'In fact, it is the most valuable spatial reserve for the development of the highest quality types and forms of tourism, of course, provided that natural and environmental values are permanently preserved.'

When it comes to tourism on the island of Pag, the research in this paper can be linked to earlier research presented in the paper by Bašić et al. (2015). In this paper, the authors, among other things, examined the opinions and attitudes of key stakeholders in the tourism of Pag, related to the branding of Pag as a spatial entity. Respondents answered that 'the island of Pag should be presented on the tourist market according to a unique umbrella brand' and further stated: 'It is necessary to jointly advertise the island as a whole and not as before where each tourist community "works for itself"'. They also believe that branding the island of Pag would achieve better, higher quality and sustainable tourism of the entire island destination. From the conducted research, the authors stated that very little work was done on branding the island of Pag as a spatial unit back then (2015), since, as the authors state, 'there is no single master plan for tourism development on the island of Pag and its D Mo (Destination Management Organization) that would put it into practice' (Bašić et al. 2015, p. 102).

Among the more recent literature, the research of Krstinić Nižić and Fugošić can be highlighted, which presented a model of sustainable development of an island destination on the example of Krk. They state that it is possible to incorporate development strategies of lower levels into a level covering a wider area, thus encouraging the development of all parts of the island of Krk, not just the developed ones. This should serve as an example to other units of local self-government in 
the Republic of Croatia, as well as in the world, to show that it is possible to act in harmony and line with the same objective by improving the quality of living for the present generation, but also for the generations to follow' (Krstinić Nižić \& Fugotić, 2019, p. 105).

\section{Sustainable Tourism vs. Mass Tourism: A Holistic Approach}

Bramwell and Lane (1993) noted that tourism has been increasingly turning towards sustainable development. They conclude that it offers some solutions, that is, it reduces misunderstandings and problems among stakeholders such as tourists, the local community, and the entire tourism sector. Krstinić Nižić and Drpić (2013, p. 160) emphasize 'the need to highlight the systematic implementation of measures and activities in the tourism industry of the Republic of Croatia, in ensuring sustainable development of a destination and in strengthening environmental awareness of all stakeholders.' Krajinović (2015) makes a similar statement, saying that sustainability is a very demanding and complex term included in numerous strategies, so every tourist destination should be engaged in its implementation as much as possible and concludes: 'The key factor in the sustainable development of a destination is the cooperation precisely and has a significant impact on the process performance success' (Krajinović, 2015, p. 69). As stated by Vukonić (2010, p. 37): 'Tourist destinations are most often guided by examples found in the professional literature, however, these examples most often come from underdeveloped areas that are sparsely populated, hence making sustainability management simpler. For this reason, it is impossible to accept such examples as an explanation of sustainable tourism, and especially not as a modality to introduce and manage sustainable development.' In this way, he builds on similar earlier theses of Jafari (1989) who asserted, 'Some authors have stated that the tourism biggest problem is its massive participation. However, when it comes to sustainable tourism, the problem is not in its extent but in the effectiveness of tourism management of a destination with an emphasis on its specificities.' Jadrešić (1999) emphasized even earlier the problem of mass tourism, which, in his opinion, is still dominant, stating: 'Although nowa-
Table 1 Difference between Mass and Sustainable Tourism

\begin{tabular}{ll}
\hline Mass tourism & Sustainable tuorism \\
\hline Unconstrained development & Controlled development \\
Quantity & Quality \\
Prominent seasonality & $\begin{array}{l}\text { Development of tourist } \\
\text { preseason and postseason }\end{array}$ \\
Reduced amount of & $\begin{array}{l}\text { Resources preservation - } \\
\text { higher level of }\end{array}$ \\
experience & consciousness \\
Mass marketing & Consumer direct \\
communication & communication \\
Mass markets & Specialized markets \\
Fast development & Slow development \\
Large groups of people & Individuals and families \\
Old tourist habits & New tourist habits \\
Existent destinations & Emerging destinations \\
Planned itinerary (travel & Spontaneous itinerary \\
program) & \\
Short-term tourism form & Long-term tourism form \\
\hline
\end{tabular}

Notes Adapted from Popesku (2011) and Butler (1999).

days tourists are starting to avoid mass tourism by looking for preserved and untouched places for their holidays, mass tourism is still not declining' (Jadrešić, 1999, p. 63). Although he wrote about this problem two decades ago, the problem of mass tourism is still ubiquitous. With increasing massive participation, the destination begins to lose quality and attractiveness and then competitiveness, so tourists are in pursuit of new destinations. Therefore, tourist destinations must make an effort to develop sustainable tourism for many reasons. The tendency to achieve environmental and social balance is essential for the preservation of the destination for the benefit of the local population and future generations. The change from mass to sustainable tourism is a long-term process of continuous improvement, and the differences between the two forms of tourism are shown in Table 1 (Popesku, 2011; Butler, 1999).

\section{Principles and Goals of Sustainable Tourism}

For sustainable tourism development, it is necessary to have a quality strategy development by applying 
three important principles of tourism sustainability: environmental, economic and socio-cultural principles (Klarin, 2017):

1. Environmental sustainability: effective use of natural resources of a destination which are crucial for the development of tourism. It is a question of maintaining and protecting biodiversity and natural wealth.

2. Socio-cultural sustainability: above all, it concerns building and preserving relationships of the local community, tradition, and cultural heritage. Intercultural respect and providing satisfaction to tourists is essential. Training and education programs to improve and manage heritage and natural resources are advised.

3. Economic viability: it is reflected in maintaining the economy of a tourist destination, that is, enabling sustainable business activities, increasing employment, and thus revenues for the purpose of achieving economic welfare.

Breslauer et al. (2015, p. 99) state: 'Local population and community, tourists, providers of products and services in the destination are some of the most important factors for sustainable development. Hence, it is very important to emphasize the importance of sustainable development and to encourage them to act under its objectives. Only those tourist destinations that know how to manage their tourist area and make optimal use of its resources will be able to survive in the future.'

Although the goals of sustainable tourism development were looking at the broader perspective in the past, today they are more oriented towards the local community. They are focused on increasing tourist satisfaction and social-economic benefits, preserving natural and cultural heritage, and reducing the unpleasant impacts of tourism on the local community in general. The publication of the umbrella tourism organization World Tourism Organization (2005) entitled Making Tourism More Sustainable: A Guide for Policy Makers lists and describes 12 sustainable tourism goals:

1. Economic viability: maintaining the competitiveness of tourist destinations and business entities in order to achieve long-term economic advancement of the local community, and thus the satisfaction of the visitors;

2. Enhancing local prosperity: encouraging local entrepreneurship and increasing the positive socialeconomic effects on the life of the local community;

3. Improving quality of employment: ensuring and improving the conditions of employment in tourism, leading to an improvement in the quality of service rendered to tourists;

4. Achieving social equity: the need to ensure social equity, that is, a fair distribution of the economic and social benefits and opportunities arising from tourism throughout the destination;

5. Tourist fulfilment: ensure a satisfactory experience for tourists by providing security and no discrimination of any kind whatsoever;

6. Increasing the quality of local governance: more intense involvement of the local community in decision-making, planning, implementation and control of sustainable tourism goals;

7. Community well-being: improving and maintaining the quality of life of local communities, avoiding any form of social discrimination;

8. Cultural wealth: preservation and protection of cultural wealth and tradition of the destination;

9. Ensuring physical integrity: preserving and improving the quality of rural and urban space, taking care of protected areas, conducting education on the importance of environmental protection;

10. Conservation of biodiversity: protection of preserved natural areas, biodiversity, and habitat, flora and fauna while reducing the negative impact of tourism on nature;

11. Efficient use of resources: reducing the use of scarce and non-renewable resources in tourism activities, and increasing the use of recycling materials and renewable energy;

12. Ensuring environmental purity: minimizing air, water and land pollution, and more frequent use of eco-friendly transportation and recycling. 
From the foregoing, it can be concluded that all the sustainable development goals are interconnected and equally important for the implementation of a sustainable tourism development policy. They cover environmental, economic, and social factors, meaning that together they form a strategy important for the further progress of the destination. The islands have to be perceived and strategically defined as a unique geographical, strategic, and marketing unity in tourism. The sustainable development of tourism on the islands is the only opportunity for their revival because should tourism be unsustainable, it could destroy the natural and cultural heritage. Such a move would result in tourists being uninterested in arriving and spending holidays on the islands and thus damaging the quality of life in the area.

\section{Sustainable Development of Island Tourism in Croatia} 'The Croatian islands have great potential, not only for the development of the area but also for the overall development of the Republic of Croatia' (Vlada Republike Hrvatske, 2018, p. 3). The Republic of Croatia has outlined in several strategic documents the principle of sustainability as one of the basic principles of development. However, the specific campaign 'The Initiative of Islands' is especially described in sequence. 'The Initiative of Islands' is a campaign launched in 2015, bringing together various companies, organizations and associations from the Croatian islands which want to promote sustainable development and raise the quality of life on the islands. Representatives of the islands of Hvar, Šolta, Vis, Brač, Korčula, Olib, Lastovo, Mljet, Cres, Prvić, Lošinj, Krk and Silba are currently participating in this campaign.' The goal of the 'The Initiative of Islands' is to primarily educate its members on the importance of sustainable tourism development, which is being sought through employment, reinvestment, linking tourism with organic food production, etc. One way is to create a virtual platform that would provide the islanders with all the necessary information in one place. It is a very interesting and successful action, as evidenced by the fact that the launching of similar campaigns in other countries such as Greece and Spain is considered (Održivi turizam u Hrvatskoj, n.d.).
The islands have numerous opportunities for the development of sustainable tourism, but in the rest of Croatia and on the islands, tourism shows noticeable features of seasonality. Additional problems are the emergence of depopulation, the abandonment of traditional activities, and the reduced quality of life in the area. 'It is for this reason precisely that tourism is an activity that needs to be developed there in order to revitalize the islands and tourism and stimulate the development or renewal of other economic activities' (Zupanc et al., 2000, p. 134).

Vidučić (2007) states that Croatian island tourism needs to address certain issues such as:

1. How to protect the space so far preserved?

2. What are the advantages for the development of a particular region?

3. What are the limitations of development?

4. What role does government and local administration play in the development?

5. Should the development be construed on cultural, historical and economic acknowledgement or some new assumptions made?

6. How to create development that will not bring itself into collapse?

In the same way, the author states: 'Each of the Croatian islands is special and offers unique content, so for this reason, it is necessary to determine a development strategy individually, provided that the natural and cultural heritage is preserved. All this can be achieved slowly and with small investments, since large investments, especially in infrastructure, could adversely affect the life and environment of the island. The cooperation of the local community, unique island tourism supply and specific island entrepreneurship supported by state incentives are what the sustainable development of the Croatian islands should be about. The task of the island's tourist destination is to maintain its authenticity, culture and tradition and build its reputation upon, whereat sustainable development should endorse such a way of life' (Vidučić, 2007, p. 43). There are numerous benefits to sustainable tourism in the islands, and some of them are listed in Table 2 according to the principles of sustainable tourism. 
Table 2 Benefits of Sustainable Tourism Development of the Island According to Its Principles

\begin{tabular}{|c|c|c|}
\hline Environmental sustainability & Socio-cultural sustainability & Economic viability \\
\hline Ensures coastal environment integrity & Helps reduce depopulation & $\begin{array}{l}\text { Enables traditional island products } \\
\text { additional value }\end{array}$ \\
\hline $\begin{array}{l}\text { Ensures sustainable use of natural } \\
\text { resources }\end{array}$ & $\begin{array}{l}\text { Restores island old cultural customs } \\
\text { and activity }\end{array}$ & Improves demographic structure \\
\hline Protects natural protected areas & Advocates shareholders' collaboration & Raises island destination standard \\
\hline Controls and reduces pollution & Helps to resolve misunderstandings & Ensures better traffic connection \\
\hline $\begin{array}{l}\text { Cares for indigenous architecture and } \\
\text { rural island scenery }\end{array}$ & Improves life quality on the islands & $\begin{array}{l}\text { Reduces energy, transport and } \\
\text { communication costs }\end{array}$ \\
\hline
\end{tabular}

Notes Adapted from United Nations Environment Program (UNEP) (2010) and Faričić and Magaš (2004).

\section{Island Of Pag as a Sustainable Tourist Destination} General Characteristics of the Island of Pag

'The island of Pag is located between the Velebit Channel and Kvarnerić, and its surface is 284.56 square kilometres, making it the largest island in northern Dalmatia' (Faričić, 2003, p. 47). 'Pag is part of the northern Dalmatian island group, and with the longest coastline it is the fifth largest island in the Republic of Croatia. The Pag Bridge connects the island to the mainland, whereas the ferry connection between PriznaŽigljen and the catamaran route operating between Novalja and Rijeka are essential for traffic connectivity' (Lončar, 2009, p. 6).

'According to the administrative-territorial division, the island of Pag is the only island divided into two counties, and the main administrative, economic and transport centre of the island is the Town of Pag. The County of Zadar covers the central and southern parts of the island, which consists of the Town of Pag and the Municipality of Povljana, while the northern part of the island belongs to the County of Lika and Senj, i.e. the town of Novalja, with the settlements of Metajna, Zubovići, Kustići, Vidalići, Caska, Gajac, Stara Novalja and Potočnica' (Magaš, 2000, p. 35).

The special features of the island of Pag are numerous sources of drinking water streaming below the sea level from Velebit mountain, and the proximity of the mountain determines the climatic conditions on the island. Namely, although the Mediterranean climate is predominant on the island, the eastern part of the island is completely bare due to strong wind (Lončar, 2009).
Tourism Specificities of the Island of Pag

'The tourist advantage of the island of Pag and the underlying fundament on what [sic] Pag builds its brand is precisely the diverse cultural and natural heritage and numerous cultural and historical monuments. Among the most important features that Pag can be commended with appertain: the world famous Pag cheese, lace and costume, Benedictine monastery, the baškotin, ${ }^{1}$ Pag Cultural Summer, the Summer Carnival and Pag Folk Drama. The island thus offers its visitors numerous facilities for rest and enjoyment' (Grad Pag \& Institut za turizam, 2015, p. 63). According to the list of categorized tourist facilities from 2019 and island of Pag data, there are 12 hotels with a total of 1053 beds, 1 apartment hotel with 32 beds and 4 campsites with a total of 10,251 accommodation units on the island of Pag (Ministarstvo turizma i sporta Republike Hrvatske, n.d.).

The tourist boards of the Town of Pag and the Town of Novalja are one of the main promoters of the island, attracting potential tourists by organizing interesting events. According to the author of this paper, one of the most useful websites for visitors to the island is Visit Pag Island, which in one place offers all the services on the island that might interest tourists. For example, it offers general information about the island (economy, history and culture), possible accommodation, itineraries, activities and tours, interesting events, excursions, and gastronomy of the island of

\footnotetext{
${ }^{1}$ Type of sweet toast produced in the Benedictine monastery where it can only be purchased (see https://pag.hr).
} 
Table 3 Ranking of Novalja in the 'Top 10' Researches of the Croatian National Tourist Board for July 2019

\begin{tabular}{lc}
\hline 'Top 10' research & Ranking \\
\hline 'Top 10' destination in Croatia by total tourist & 7th place \\
turnover in July 2019 & \\
'Top 10' destination in Croatia by tourist camp- & 7th place \\
ing turnover in July 2019 & \\
'Top 10' destination in Croatia by family ac- & 4th place \\
$\begin{array}{l}\text { commodation in July } 2019 \\
\text { 'Top 10' destination in Croatia by non- }\end{array}$ & 4th place \\
commercial accommodation in July 2019 & \\
'Top 10' destination in Croatia by turnover of & 4th place \\
domestic tourists in July 2019 & \\
'Top 10' destination in Croatia by turnover of & 6th place \\
foreign tourists in July 2019 & \\
\hline
\end{tabular}

Notes Adapted from Hrvatska turistička zajednica (2019).

Pag. On Pag, there is a part of the island dedicated to those seeking peace and quiet for their vacation, but the island also offers numerous services for those eager for good fun. The world-renowned Zrće (Novalja) 'party destination' has been known for many years for attracting an increasing number of tourists, which is why it is a leader in occupancy of accommodations over the rest of the island. This is confirmed by the fact that according to the Croatian Tourist Board issue on statistical indicators of tourist turnover for the month of July (2019), Novalja is in almost every 'Top ${ }_{10}$ ' research $^{2}$ in the results by destination (Table 3 ).

'The strategic goal of tourism development on the island of Pag is to create a unique tourism product based on rich culture and historical heritage in order to diverge from other destinations. This is the origin of a vision of Pag as a sustainable destination that, according to the needs and expectations of highly segmented buyers of tourism products, such as sun and sea, sports and recreation, gastronomy, cultural, nautical and health tourism, provides a healthy and dynamic holiday. In addition, the quality of life of the lo-

${ }^{2}$ According to the information on the course of the season, which shows the indicators of tourist turnover achieved at monthly intervals, the Ministry of Tourism compiled a list of the 'Top 10' destinations according to different criteria.
Table 4 Principles of Sustainable Tourism on the Island of Pag

\begin{tabular}{ll}
\hline Principle & Item \\
\hline Spatial-environmental & Viability \\
& Use of responsible practice \\
\hline Social sustainability & Partnership \\
& Preserving the spirit of the place \\
\hline Economic viability & Innovation and quality \\
& Coordination \\
\hline
\end{tabular}

Notes Adapted from Grad Pag \& Institut za turizam (2015).

cal population, tradition and environmental concerns must not be forgotten. The island also has numerous opportunities to develop selective forms of tourism such as hunting and fishing, health, rural tourism and protected cultural heritage tourism' (Grad Pag \& Institut za turizam, 2015, p. 24).

\section{Principles of Sustainable Tourism Development on the Island of Pag}

'The tourism of the island of Pag is based on raising the quality and standard of living of the local population by promoting activities based on tradition and sustainable use of natural resources [...] The development of sustainable tourism on the island emphasizes environmental protection, culture of quality, the uniqueness of the destination, growth of entrepreneurship and stakeholder partnership' (Grad Pag \& Institut za turizam, 2015, p. 53). The strategic plan for tourism development of the town of Pag from 2016 to 2020 (Grad Pag \& Institut za turizam, 2015), defines the principles of sustainable tourism on the island of Pag, which are described below.

The environmental principle of sustainable development of the island defines the optimal way of using and managing the space, both natural and cultural heritage. It also involves caring for the preservation of development potential, the implementation of 'green' business practices, and encourages residents and visitors to reduce adverse environmental impacts. According to the document of the Utility Company $\mathrm{Pag}^{3}$ Strategy of Development of the Utility Company Pag

${ }^{3}$ Established in 1995, and performs activities such as collec- 
LLC from 2016 to 2020 (Komunalno društvo Pag, 2015), the main objective of environmentally sustainable development is the permanent preservation of originality and biodiversity, the conservation of aquatic and wetland habitats, and the avoidance and reduction of waste generation.

The social and cultural principle of the island aims to preserve the unique features of the local community such as the traditional costume of the Town of Pag, Pag lace protected by unesco, and various cultural manifestations such as the Pag Cultural Summer. The quintessence is the creation of a tourist offer in compliance with the 'spirit' of the destination and the life of the local community. At the core of the sociocultural principle is the principle of partnership, aimed at stakeholders' cooperation for the purpose of developing island tourism (Grad Pag \& Institut za turizam, 2015). Precisely this cooperation between stakeholders plays a very important role on the island since Pag is divided into two counties and is the only island where two different regional governments operate. In the above-mentioned paper, Bašić et al. (2015) propose the creation of a single destination management organization, that is, the Destination Management Organization (DMO), whose task would be to manage tourism throughout the island. Such an approach would very likely solve the problem of uneven development on the island.

'The goal of the economic principle is to increase the number of investment projects and the positive effects of economic activity on the environment. The innovation and quality of all business entities are key elements of competitive advantage. It is very important to align public and private projects with the goal, vision, and mission of the island tourism development and the focus is on several smaller sustainable investments' (Grad Pag \& Institut za turizam, 2015, p. 54).

According to the 'Town of Pag Activity Plan,' which is described in the strategic plan for tourism development of the town of Pag, some of the investments are the improvement of the system of tourist information centres, beach cleaning, development and im-

tion, treatment, distribution of water, etc. (see https://kdpag.hr/). provement of the hotel offer, development of health and tourist facilities, elaboration of detailed plans for the most important tourist zones on the island and others (Grad Pag \& Institut za turizam, 2015).

\section{Empirical Research}

Research Objective and Methodological Framework

This part of the paper describes the results of primary research that offer a holistic view on the issue of island sustainability and island tourism on the example of the island of Pag. Of particular interest is the question of whether respondents believe that the sustainability of the island develops under all three criteria/aspects of sustainable development - economic, socio-cultural, and environmental - and what importance they attach to each of these aspects. Cohen (2017, p. 26) states: 'Tourism researchers have related to the role of the islands' inhabitants in tourism development, but paid scarce attention to the wider effects of tourism penetration upon island societies. [...] Most tourism researchers show little concern for the effects of tourism on local socio-cultural change.' In this sense, an interview/survey questionnaire is structured, which consists of the same questions in order to be able to perform a comparative analysis. They are structured in such a way that the results of the research can be used to determine the basic limiting factors of sustainable tourism development on the island of Pag, and to assess their importance, according to the respondents. Furthermore, respondents were asked about the selection of the selective form of tourism that would most contribute to the development of off-season tourism in the function of sustainable development. The participants were asked to assess the extent of sustainable tourism development on the island of Pag, as well as to choose the principle according to which they believe that tourism on the island should be developed to the greatest extent. The questionnaire/interview consisted of 4 complex questions. The research has been carried out in a broader sense as part of an internal university project on the development of sustainable tourism at the Department of Economics, University of Zadar, Croatia, and in a narrower sense as part of the research for the master's thesis Island of Pag as a Sustainable Tourist Destination (Miletić, 2019). The primary re- 
search has been conducted by a method of combining expert interviews and surveys. Then, a comparative analysis of the research results has been performed using interviews and survey results. The research was conducted in August 2019 on the island of Pag. Key stakeholders in tourism on the island of Pag were examined, employed in the following institutions and organizations: information centres, hotels, tourist agencies and camps. An expert from the Tourist Board of the City of Pag was interviewed. A total of 21 respondents participated in the survey. The results of interviewing experts from the Tourist Board of the City of Pag are specifically separated and compared because it was assumed, since the Tourist Board is the umbrella organization for tourism development, its opinion aggregates the opinions of many other stakeholders members of the Tourist Board. Since the aim of the research was to look holistically at the issue of sustainability on the Island, the opinion of the representatives of the tourist community is of special importance for the goal of the research. Therefore, according to the authors, it should be singled out. The smaller number of respondents - tourism experts on the island in the survey can be partially justified by the fact that the island of Pag does not have a large number of commercial accommodation facilities, which makes the issue of sustainable tourism even more challenging.

\section{Research Results}

This section of the paper displays results of the survey and especially analyses the feedback of respondents from the Town of Pag Tourist Board. The first part of the analysis explores the greatest problems facing islands that hinder the development of sustainable tourism. There were five problems offered: mass tourism, lack of investment projects, uncontrolled apartmentisation, loss of quality labour in tourism and uneven tourist development of the island. Respondents rated 1 to 5 on the importance of each problem, noting that rating 1 meant that the problem was insignificant on the island, and rating 5 indicating that the problem was of the highest importance.

The first problem mentioned was mass tourism on the island of Pag, and the results of the assessment of importance by the respondents are shown in Figure 1.

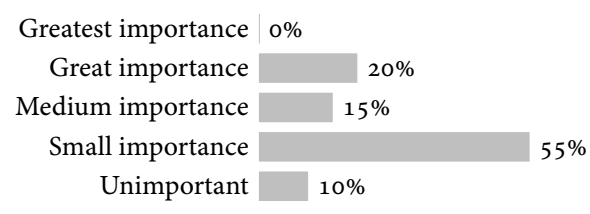

Figure 1 Assessment of Mass Tourism Importance on the Island of Pag

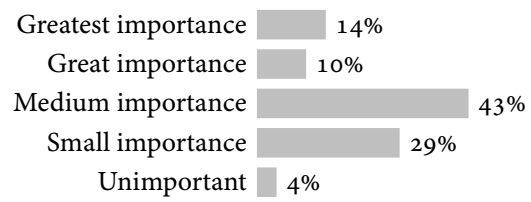

Figure 2 The Assessment of the Lack of Investment Projects Problem Importance on the Island of Pag

According to the results obtained, it can be concluded that mass tourism does not pose a great threat to the island of Pag. None of the respondents rated the massive scale with 5 , i.e. did not consider it to be a problem of the utmost importance. A respondent from the Town of Pag Tourist Board evaluated the mass tourism on the island with rating 4 , which means that such respondents considered this problem to be of great importance. However, the majority of respondents (55\%), who anonymously completed the survey, consider that mass tourism as an island problem is of little importance, i.e. their answers indicate they believe that there are bigger problems on the island than mass tourism.

Figure 2 shows the information on the problem of lack of investment projects on the island of Pag. Opinions of anonymous respondents were divided, as $43 \%$ rated this issue with 3 or of medium importance in scale, and $29 \%$ said the problem was almost insignificant where the island of Pag is concerned. Of the 21 respondents, $14 \%$ said that the lack of investment projects is of the greatest importance on the island. A respondent from the Town of Pag Tourist Board considers this to be of medium importance, which implies the need to solve it.

When it comes to the problem of uncontrolled apartmentisation, the respondents generally agree that this is one of the issues that need to be addressed more. 


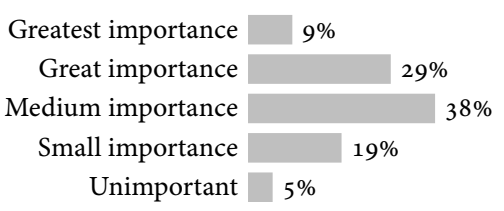

Figure 3 Assessment of Uncontrolled Apartmentisation Problem on the Island of Pag

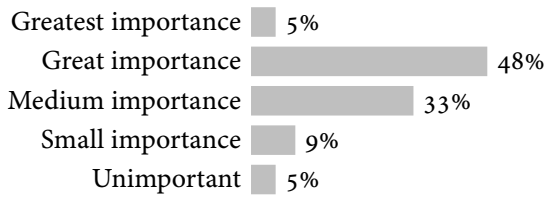

Figure 4 Assessment of the Loss of Quality Labour Problem in Tourism on the Island of Pag

$38 \%$ say it is a problem of medium importance, while $29 \%$ say that its importance is the greatest. Only 5\% of the respondents rated the problem of uncontrolled apartmentisation with 1 , meaning that such an issue does not pose a major threat to the island of Pag. It is very important to point out the answer of the respondent from the Town of Pag Tourist Board, who rated this problem with 5 , that is, assigned the highest importance to the uncontrolled apartmentisation among all mentioned problems in the survey.

According to the results of an empirical study on the loss of quality labour in tourism as a problem of the island of Pag, $48 \%$ of respondents described it as a problem of great importance, while $33 \%$ considered it to be of medium importance. $5 \%$ of those interviewed anonymously think that the problem is unimportant on the island, while $5 \%$ of the 21 respondents think the opposite, that is, the loss of good labour in tourism is a great problem on the island of Pag. The rest of the respondents, $9 \%$ of them, rated the problem of loss of quality labour in tourism as of small importance. The opinion of the respondent from the Town of Pag Tourist Board is in accordance with the opinion of 33\% of anonymous respondents, namely they consider it to be a problem of medium importance on the island of Pag. Recently, quality labour is leaving not only from the tourism industry but from all economic areas.

The last problem in the questionnaire, rated by the

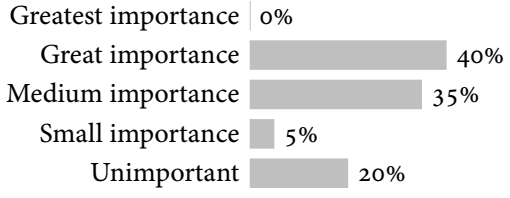

Figure 5 Assessment of the Uneven Tourist Development Problem on the Island of Pag

respondents with a score from 1 to 5 , was the problem of uneven tourist development of the island of Pag, and the results are presented in Figure 5.

When asked about the problem of uneven tourist development on the island of Pag, 21 respondents provided an answer, 20 of them anonymously, 1 respondent did not respond, and one respondent from the Town of Pag Tourist Board answered. Figure 5 shows that $40 \%$ of respondents think that this is an issue that needs to be addressed as soon as possible, that is, they described it as a problem of great importance on the island. Likewise, $20 \%$ think that this problem is completely unimportant. It is very important to emphasize the opinion of the respondent of the Town of Pag Tourist Board, who agrees with the opinion of $5 \%$ of anonymous respondents, that is, believes that the island has an almost even development of tourism.

The pronounced seasonality is one of the biggest tourism problems in the Republic of Croatia. According to the 'Croatia 365 ' project, tourist destinations should be promoted with their specific features in order to stimulate the off-season tourist movement. Also, in solving the above-mentioned problem, it is desirable to develop selective forms of tourism in destinations. The survey included the question of what point of advantage, or what endeavour, could reduce the seasonality in tourism of the island of Pag.

Respondents were given the possibility of multiplechoice, but a maximum of 3 . In Figure 6, development projects were ranked in order of importance by the opinions of anonymous respondents. According to the results, the advantage by which the island of Pag could be promoted to reduce seasonality is the development of rural tourism (61.9\% of respondents). The respondent from the Town of Pag Tourist Board cited the development of health tourism, construction of bicycle 


\begin{tabular}{r|r} 
Other & $0 \%$ \\
Developing business tourism & $19 \%$ \\
Building higher cat. hotels with additional services & $24 \%$ \\
Developing hunting and fishing tourism & $43 \%$ \\
Building bicycle paths and promoting cycling & $52 \%$ \\
Developing health tourism & $52 \%$ \\
Using its cultural heritage and tradition & $52 \%$ \\
Developing rural tourism & $62 \%$
\end{tabular}

Figure 6 Development Measures Aimed at Reducing the Seasonality of Tourism on the Island of Pag

\begin{tabular}{|c|c|}
\hline Economic Principle & $15 \%$ \\
\hline Social-cultural principle & $35 \%$ \\
\hline Economy principle & \\
\hline
\end{tabular}

Figure 7 Ranking the Importance of Sustainable Tourism Principles on the Island of Pag

paths and cycling, cultural heritage and tradition as a desirable way of promotion during the off-season period.

Figure 7 lists the respondents' answers on the importance of a particular principle of sustainable tourism development on the island of Pag.

According to the empirical survey, as many as 55\% of respondents believe that the island of Pag should be more environmental, $30 \%$ say it is a socio-cultural problem, and $15 \%$ say that it is the economic principle due to a problem of poor development of sustainable tourism on the island of Pag. The respondent from the Town of Pag Tourist Board agrees with the opinion of most anonymous respondents and responded that the environmental principle was one that the island should pay more attention to. Environmental care is an essential determinant for the further development of the island, while preserving the quality of the environment is a prerequisite for long-term sustainable development. The figure also indicates to what extent sustainable tourism is currently developed on the island of Pag.

According to the results of the anonymous survey, $47.6 \%$ of respondents stated that sustainable tourism is developing poorly on the island, while $19 \%$ believe that the island of Pag is doing very well in leading the sustainable tourism development policy. None of the respondents answered that sustainability is developing

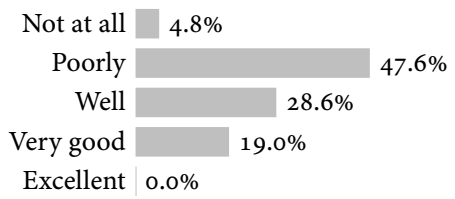

Figure 8 Development of Sustainable Tourism on the Island of Pag

excellently on the island, and particularly interesting is the response of the respondent from the Town of Pag Tourist Board who believes that sustainable tourism is not developing at all in this region.

\section{Discussion}

The conducted empirical research provided intriguing answers, and the opinions of the respondents confirm or respectively reject the hypothesis stated: The island of Pag is successfully implementing a sustainable tourism policy, regardless of the problems encountered as a tourist destination. According to the results of the empirical research, the respondents described the development of sustainable tourism on the island of Pag as very bad, and this is further confirmed by the respondent from the Town of Pag Tourist Board, who believes that sustainability does not apply at all in the process of island development. For this reason, the hypothesis is rejected. In order to change this situation, it is first of all necessary to solve issues such as uncontrolled apartmentisation, the loss of quality tourism labour and inequalities in island development, which were rated as of great importance by the respondents, in order for sustainability to develop. By establishing a unique organization of destination management, these limitations could be resolved, and sustainability could develop smoothly and properly. The backbone of tourism sustainability is found in three principles that must be equally promoted, namely, the environmental, economic, and socio-cultural principles. Most respondents $(55 \%)$ consider the environmental principle to be the least developed principle on the island of Pag. This is another argument confirming the poor development of sustainable tourism in the area. However, in the period after the primary research, two significant changes were made. They are described below. 
The first DMOs as the central destination management organizations have entered the legislation of the Republic of Croatia. The amended 'Law on Tourist Boards and the Promotion of Croatian Tourism' ('Zakon o turističkim zajednicama i promicanju hrvatskog turizma,' 2020) states: (Art. 1): 'This Law, according to the model of destination management organization, regulates the system of tourist boards, organization, tasks, and manner of work of tourist boards and basic principles of their financing and management.' (Art. 2): '2. Destination management organization is defined as an organization that brings together stakeholders from the public, private and civil sectors for the strategic and operational management of the destination and the realization of a common, previously agreed vision. 3 . The principle of destination management implies the tourism activities of stakeholders, unitary purposeful business cooperation, to develop an integrated and competitive destination product.'

Furthermore, key Pag tourist stakeholders have united to uniquely brand the island, which they achieved by activating the Visit Pag portal (http://www.visit -pag.com), and to implement other integrated projects. For example, the leaders of Pag's tourist towns signed an Agreement on the association of local tourist communities from the island of Pag in the implementation of the project 'Development of Outdoor Tourism on the Island of Pag' which aims to develop and shape the island into a unique, harmonized and marketestablished destination. The media state: 'It is, we can freely say, a historical moment in which all the island's tourist boards signed such a multi-year joint project for the first time, which is important for tourism and quality offer of the entire island of Pag' (Udruživanje lokalnih turističkih zajednica u provedbi projekta 'Razvoj outdoor turizma na otoku Pagu,' n.d.). The signing of this Agreement was approved by the Commission of the Ministry of Tourism of the Republic of Croatia, which provided the preconditions for applying for the Fund for United Tourist Boards of certain areas for joint development of tourism products and destination promotion, established in 2020. The Agreement presents, in detail, the activities that should, with the financial support of the Ministry of Tourism of the Republic of Croatia, be implemented by the end of
2023. 'This is a logical continuation of the previous continuous cooperation, since the tourist boards of the island of Pag have more than three years ago set out on a joint path of cooperation under the motto "Pag Moon Island - A Common Vision". This fully respects the intention of the Ministry of Tourism of the Republic of Croatia to encourage project association of tourist boards in an area because tourism exceeds administrative boundaries and therefore legislative changes have been made to enable joint presentation and development of destinations which, although special in their way, form a complete tourist story' (Udruživanje lokalnih turističkih zajednica u provedbi projekta 'Razvoj outdoor turizma na otoku Pagu,' n.d.).

\section{Conclusion}

Sustainable tourism development implies responsible management of the area, with an emphasis on natural and cultural heritage, and aims to meet the needs of tourists and needs of current and future local communities. With the development of sustainability, destinations maximize their potential while creating a balance between three important principles: environmental, economic and socio-cultural. For this reason, sustainability has recently been one of the most commonly used terms in tourism.

Croatia is a destination that repeatedly attracts many tourists for its beauty. Still, a massive scale tourism and seasonality problem emerges and hinders the development of sustainability. Through various projects, the most famous being 'Croatia 365', Croatia is struggling against the seasonality problem. Due to its authenticity, the Croatian islands are one of the great potentials in terms of tourism. One of its assets is the island of Pag, building its tourist identity on cheese, salt and lace as traditional elements. On the other hand, the island brand is being also built by Novalja, as a world-famous party destination.

According to the empirical research presented in this paper, sustainable tourism is developing very poorly on the island of Pag. It is so due to numerous limitations, such as excessive apartmentisation, loss of quality labour in tourism, massive scale tourism, and others. Among the significant problems that make sustainable tourism poorly developed is the division of 
islands in two counties and generally uneven development. As many as $47.6 \%$ of the respondents who participated in the primary survey presented in this paper believe that sustainable tourism is developing very poorly on the island. One of the important measures in the area of sustainability is the idea of establishing a DMO, an organization that would take care of tourism development, based on which the above problems would be minimized, and the development of sustainable tourism would proceed. Consequentially, the Dмо would have a broader perspective, and pay attention to the balance among all the principles, especially the environmental one, which the respondents rated as the least tended principle in the island of Pag. The most important task of the DMO in Pag would be to ensure a balanced development of tourism in all parts of the island. By establishing such a unique organization of destination management, sustainability could be developed smoothly and properly. In this sense, the Republic of Croatia has already taken certain steps, both in improving the legislation in the field of destination management and on the island of Pag, where tourism stakeholders have joined forces to unite marketing activities for sustainable tourism development.

As a major limitation of the primary research conducted in this paper, the authors emphasize the fact that the survey did not cover all tourist stakeholders on the island. The authors recommend further similar research and comparisons between the developments of island tourism sustainability in Croatia with other competitive island tourist destinations. As a scientific implication of this paper, the authors point to the quest for a unique model of sustainable tourism development in island tourist destinations and a contribution to the scientific debate in this regard. As practical implications, the results of the research presented here can serve policymakers at all levels, as well as the strategic management of tourism entities on the island in formulating guidelines for further development.

Finally, it should be emphasized that the sustainability and sustainable development of tourism themes, especially in the islands as extremely fragile geographical, economic and socio-cultural entities, is of particular importance. The complexity of the term sustain- ability is best described by a quote from the author Smolčić Jurdana (2003, p. 161): 'Sustainable development is not a current state but a never-ending process.'

\section{References}

Apostolopoulos, Y., \& Gayle, D. J. (Eds.). (2002). Island tourism and sustainable development: Caribbean, Pacific, and Mediterranean experiences. Praeger.

Bašić, T., Krajnović, A., \& Bosna, J. (2015). Neke smjernice za brendiranje otoka Paga u funkciji razvoja turizma. Holon: postdisciplinaran znanstveno-stručni časopis, 5(1), 92-107.

Bramwell, B., \& Lane, B. (1993). Sustainable tourism: An evolving global approach? Journal of Sustainable Tourism, 1(1), 1-5.

Breslauer, N., Gregorić, M., \& Hegeduš, I. (2015). Održivi razvoj turizma u Međimurskoj županiji. Obrazovanje za poduzetništvo - E4E, 5(1), 99-109.

Brown, K. G., \& Cave, J. (2010). Island tourism: Marketing culture and heritage. International Journal of Culture, Tourism and Hospitality, 4(2), 87-95.

Butler, R. (1999). Sustainable tourism: A state-of-the-art review. Tourism Geographies, 1(1), 7-25.

Carlsen, J., \& Butler, R. (2011). Island tourism: Towards a sustainable perspective. C A B I.

Cohen, E. (2017). Towards a convergence of tourism studies and island studies. Acta Turistica, 29(1), 7-31.

Čavlek, N., \& Vukonić, B. (2001). Rječnik turizma. Masmedia.

Faričić, J. (2003). Otok Pag na starim kartografskim prikazima. Geoadria, 8(1), 47-126.

Faričić, J., \& Magaš, D. (2004). Suvremeni socio-geografski problemi malih hrvatskih otoka - primjer otoka Žirja. Geoadria, 9(2), 125-158.

Grad Pag \& Institut za turizam. (2015). Strateški plan razvoja turizma Grada Paga za razdoblje od 2016.-2020. godine. https://www.pag.hr/index.php/gradska-uprava/ savjetovanje-s-javnoscu/strateski-plan-razvoja-turizma

Hrvatska turistička zajednica. (2019). Informacija o statističkim pokazateljima turističkog prometa - srpanj 2019. https:/htz.hr/hr-HR/informacije-o-trzistima/ informacije-o-tijeku-sezone

Jadrešić, V. (1999). Proturječja i negativne pojavnosti u turizmu. Tourism and Hospitality Management, 5(1-2), 5567.

Jafari, J. (1989). Sociocultural dimensions of tourism: An English language literature review. Tourism as a Factor of Change: A Sociocultural Study, 1(1), 17-6o.

Klarin, T. (2017). Kreiranje modela održivog razvoja turizma 
u urbanim destinacijama Republike Hrvatske [Unpublished doctoral dissertation]. Sveučilište u Rijeci.

Kokkranikal, J., McLellan, R., \& Baum, T. (2003). Island tourism and sustainability: A case study of the Lakshadweep Islands. Journal of Sustainable Tourism, 11(5), 426447.

Komunalno društvo Pag. (2015). Komunalno društvo Pag: strategija razvoja 2016.-2021. https://kd-pag.hr/images/ pdf/strategijarazvoja.pdf

Krajinović, V. (2015). Propitivanje ključnih izazova u mjerenju održivog razvoja turizma. Acta Turistica, 27(1), 6391.

Krstinić Nižić, M., \& Drpić, D. (2013). Model for sustainable tourism development in Croatia. V 2st International Scientific Conference Tourism in South East Europe 2013; Crisis - A Challenge of Sustainable Tourism Development (pp. 159-173). University of Rijeka, Faculty of Tourism and Hospitality Management Opatija.

Krstinić Nižić, M., \& Fugošić, N. (2019). Integrated sustainable development on a local level - The Island of Krk as an example. Pomorski zbornik, 56(1), 89-108.

Lambert, E. (2009). Nature island tourism: Applying an ecotourism sustainability framework to the island of Dominica [Unpublished master's thesis]. University of Waterloo.

Lim, C. C., \& Cooper, C. (20o8). Beyond sustainability: Optimising island tourism development. International Journal of Tourism Research, 11(1), 89-103.

Lončar, N. (2009), Geomorphologic regionalization of the central and southern parts of Pag Island. Geoadria, 14(1), 5-25.

Magaš, D. (200o). Contribution to the knowledge of the geographical characteristics of the Pag island. Geoadria, 5(1), $5-48$.

Mai, T., \& Smith, C. (2015). Addressing the threats to tourism sustainability using systems thinking: A case study of Cat Ba Island, Vietnam. Journal of Sustainable Tourism, 23(10), 1504-1528.

Mikačić, V. (1994). Otočni turizam Hrvatske. Društvena istraživanja - časopis za opća društvena pitanja, 3(12-13), 517-529.

Miletić, N. (2019). Otok Pag kao održiva turistička destinacija [Unpublished master's thesis]. Sveučilište u Zadru.

Ministarstvo turizma i sporta Republike Hrvatske. (N.d.). Kategorizacija. Retrieved 20 November 2019 from https: //mint.gov.hr/kategorizacija-11512/11512

Ng, S. I., Chia, K. W., Ho, J. A., \& Ramachandran, S. (2017). Seeking tourism sustainability - A case study of Tioman Island, Malaysia. Tourism Management, 58(c), 101-107.
Održivi turizam u Hrvatskoj. (N.d.). Pokret otoka. http:// www.odrzivi.turizam.hr/default.aspx $?$ id $=5746$

Popesku, J. (2011). Menadžment turističke destinacije. Univerzitet Singidunum.

Smolčić Jurdana, D. (2003). Prednosti i ograničenja primjene koncepcije održivog razvoja turizma, doktorska disertacija [Unpublished doctoral dissertation]. Sveučilište u Zagrebu.

Sunara, Ž., Jeličić, S., \& Petrović, M. (2013). Održivi turizam kao konkurentska prednost Republike Hrvatske. Zbornik radova Medimurskog veleučilišta u Čakovcu, 4(1), 83-88.

Udruživanje lokalnih turističkih zajednica u provedbi projekta 'Razvoj outdoor turizma na otoku Pagu.' (N.d.). Morski.hr. https://morski.hr/2020/o6/12/pag -udruzivanje-lokalnih-turistickih-zajednica-u-provedbi -projekta-razvoj-outdoor-turizma-na-otoku-pagu/

United Nations Environment Program. (2010). UNEP annual report 2009: Seizing the green opportunity [Brochure].

Vidučić, V. (2007). Održivi razvoj otočnog turizma Republike Hrvatske. Naše more: znanstveni časopis za more $i$ pomorstvo, 54(1-2), 42-48.

Vlada Republike Hrvatske. (2018). Izvješće o učincima provedbe zakona o otocima u 2017. godini. https://razvoj.gov .hr/dokumenti/10

Vlahović, D. (2001). Koncepcijski okvir politike razvitka otočnoga turizma. Ekonomska misao i praksa, 10(2), 213231.

Vukonić, B. (2010). Je li održivost upitna? Acta turistica nova, 4(1), 33-42.

World Tourism Organization. (1998). Guide for local authorities on developing sustainable tourism. https://www.e -unwto.org/doi/book/10.18111/9789284402809

World Tourism Organization. (2005). Making tourism more sustainable: A guide for policy makers. https://www.e -unwto.org/doi/book/10.18111/9789284408214

Zakon o turističkim zajednicama i promicanju hrvatskog turizma. (2020). Narodne novine, (42). https://www .zakon.hr/z/342/Zakon-o-turisti\%C4\%8Dkim -zajednicama-i-promicanju-hrvatskog-turizma

Zupanc, I., Opačić, V., \& Nejašmić, I. (200o), Utjecaj turizma na demografska kretanja hrvatskih otoka. Acta Geographica Croatica, 35(1), 133-145. 



\section{A Destination's Social Sustainability: Linking Tourism Development to Residents' Quality of Life}

\author{
Emil Juvan \\ University of Primorska, Faculty \\ of Tourism Studies - Turistica, Slovenia \\ emil.juvan@fts.upr.si
}

Eva Podovšovnik

University of Primorska, Faculty

of Tourism Studies - Turistica, Slovenia

eva.podovsovnik@fts.upr.si

\author{
Miha Lesjak \\ University of Primorska, Faculty \\ of Tourism Studies - Turistica, Slovenia \\ miha.lesjak@fts.upr.si
}

\section{Jasmina Jurgec}

Sava turizem d.d.

jurgec.jasmina@gmail.com

Tourism positively contributes to quality of life (satisfaction with life and emotional wellbeing) of the travelling population, but the question remains how tourism affects quality of life of the host population. Residents' quality of life is an essential aspect of sustainable tourism development and offers an attractive destination attribute for marketing. Research suggests that too much interaction with tourism may reduce hosts' quality of life. Low quality of life, typically demonstrated with a low level of satisfaction with life and poor emotional wellbeing, leads to development of antitourism beliefs and reduces residents' support for tourism. This may impede local policy makers and the tourism industry from developing tourism. High tourism may create income but may also induce public expenses on the account of social costs of tourism. The present study investigates the association of hosts' satisfaction with life with objective (level of tourism development) and subjective (perceived interaction with tourists) levels of tourism development. Results indicate that neither the level of tourism development nor interactions with tourists predict hosts' satisfaction with life and their emotional wellbeing. These findings challenge the existing prevailing assumption that a high level of tourism negatively affects residents' quality of life, by default. A call for empirical evidence on the threshold of quantitative (for example frequency) and qualitative (for example, the nature of the interaction) tourism development is needed to reveal how local authorities can better ensure positive social impacts of tourism on the host population and tourism social sustainability.

Keywords: sustainable tourism, social sustainability, quality of life, residents, destination

(cc)BY-SA https://doi.org/10.26493/2335-4194.14.39-52

\section{Introduction}

Over the last couple of decades, tourism has undergone continuous expansion and diversification to become one of the largest and fastest growing economic sectors in the world (World Tourism Organization,
2017). Tourism is about movement and interaction of people within and away from their everyday environment. This interaction affects how the interacting individuals perceive, feel and think about the social environment; consequently, tourism shapes 'hosts' and 
visitors' lifestyles' (Sharpley, 2014, p. 2). While much of our knowledge about tourism impacts pertains to the aspects of visitors, little is known about the diverse impacts tourism has on the local population. Knowledge of tourism development trends has essential meaning for the continuous prosperity of a destination. Destinations typically embrace existing market demand, attract tourists' attention and support opportunities for tourist visitation. Tourist demand changes over time, but one of the fastest-growing aspects of tourism demand is tourists' awareness of the need to protect the host environment (Buckley, 2011; Peeters et al., 2018). Moreover, tourism sustainability is becoming the paradigm of modern times and with it the interest to preserve and even increase the quality of the host environment (Peeters et al., 2018). Green, healthy and active forms of leisure activities are attracting an increasing number of people. Also, high quality is increasingly present in all aspects of tourism supply, especially in the area of social relations between people involved in tourism (highquality, top-quality tourist service adjusted to the individual) (Vodeb, 2014). Tourist arrivals, tourism infrastructure and tourists' experiences offered change the destination's landscape and inevitably affect residents' lives (Kim et al., 2013; Liang \& Hui, 2016, p. 1). Kubickova et al. (2017, p. 1) argue that 'individuals' perceptions shape the quality of life, which is a multidimensional paradigm with many interpretations of subjective or objective nature.' The impacts of tourism depend on the interaction with tourism and level of tourism development, and hosts may perceive this impact as added or reduced quality of life; the latter may also bring to a serious level residents' irritation over tourism (Doxey, 1975).

Given the tourism trends (World Tourism Organization, 2019) we anticipate that the tourism industry will have a massive expansion in the future, which will bring much appreciated economic benefits to tourist destinations; however, growing tourism also brings a number of negative impacts, including unwanted changes in hosts' lifestyles (Peeters et al., 2018). While investigating the relationship between tourism at various levels of development and residents' quality of life is not new (for example, Doxey, 1975; Murphy, 1985;
Perdue et al. 1990), the generalizability of the relationship remains under-investigated. The present study discusses the social aspects of tourism development, more specifically the perceived quality of life among residents of destinations in different stages of tourism development. It is aimed at contributing to the knowledge about social impacts of tourism for the host residents and within that deriving empirically supported practical implications for the destinations' organizations and policy makers about how to develop tourism, which will increase not only tourist satisfaction with life but also contribute to the life satisfaction of the host population.

\section{Theoretical Background}

Tourism impacts tourists and locals in many ways. A number of different approaches and aspects investigating tourism impacts were adopted in the past; nevertheless, it appears that researchers have 'traditionally assessed the utilitarian attributes of tourism products and services' (Lin et al., 2014, p. 1) in spite of the fact that tourism experiences include a strong affective (i.e. emotional) component (Gnoth, 1997). More attention should therefore be paid to understanding the source of emotions and behaviour, as they play an important role in shaping attitudes not only for tourists, but also for locals. Through a number of consequences which tourism brings to the local community, tourism affects locals' perceptions and actual quality of life. Tourism should focus on the emotional interaction between the host and the guest, as there is still a lack of research into the impact of residents' emotions and consequent impact on their beliefs about and behaviour towards tourism (Ribeiro et al., 2017).

Individuals express their thinking in words, which are based on the emotional experiences at a given time. Thus, the formation of emotions can be influenced by a particular situation, surroundings or events, in connection with the individual's perception. Guests and hosts can build a (strong) contact, allowing them to share experiences, advice, and maybe later develop an emotional attachment. Allport (1961) defines personality 'as a dynamic organization within an individual's psychological and physical systems based on patterns of actions, thoughts, and feelings.' An individual's per- 
sonality is influenced by a number of factors that are shaped by a variety of perceptions. A positive perception of the environment, events and people can lead to positive feelings (including being fulfilled and happy), which is an important factor of quality of life (Dolnicar et al., 2012). Emotions form emotional wellbeing, which is the actual or perceived quality of one's everyday life, typically expressed via feelings of joy, stress, sadness, anger, and fear (Kahneman \& Deaton, 2010) and is one of the seven domains of quality of life (Cummins, 1993). Emotional wellbeing is affected by the level of tourism development (Williams, 1979). More specifically, diverse and rich tourism infrastructure and experiences (for example, events) improve or reduce the emotional wellbeing of residents (Uysal et al., 2012). It is suggested that provision of tourist attractions based on local culture, tradition, lifestyle and history, which are readily available to the local population, will 'foster the emotional well-being of the resident community' (Uysal et al., 2012, p. 440). Different levels of tourism development and interaction with tourists, which are both alleviated with an increased level of tourism development (Butler, 1980), affect one's emotional wellbeing. More specifically, an extended level of interaction with tourists may make local residents irritated. Such interaction may be materialized either through employment in tourism (Pizam, 1978) or simply by living closer to tourist concentration areas (Belisle \& Hoy, 1980). This clearly shows that the level of tourism development and interaction with tourists will have an impact on residents' emotional wellbeing.

Happiness is a personal state derived from positive and negative emotions following one's life events (Sirgy \& Lee, 2006). A number of life events and one's personal or situational characteristics may impact one's feeling of happiness (Rivera et al., 2016, p. 1). Given this view, tourism should be considered as a situation having a different level of impact on an individual's life. For example, at destinations with a larger number of tourists a chance of waiting in queues at a local grocery store or experiencing difficulties with parking a car is by far greater than at destinations with a lower level of tourists; not finding a car park or waiting in long queues will reduce one's feeling of happiness and lower one's perceived satisfaction with life. On the other hand, tourism may also positively affect locals' perception of happiness, given that it is one of the largest start-up trading companies for creating happiness on the planet (Pearce et al., 2011). For example, a well-developed tourism industry provides opportunities for high quality recreation or culinary experiences, which should increase locals' feeling of happiness and satisfaction with life. Hence, no doubt, that tourism industry may be making tourists happy, but the question remains how the tourism industry affects residents' emotional wellbeing and life satisfaction.

Happiness enhances people's personal satisfaction, which contributes to satisfaction with life. Countries with happier residents may benefit more from residents' satisfaction, which may become an intangible destinations asset for managing and marketing with international visitors (Gholipour et al., 2016). Happiness is a major contributor to one's perceived quality of life and a sense of happiness encourages factors of pleasure and achievement (Mohit, 2014). One of the approaches for measuring quality of life is the Gross National Happiness Index aimed at assessing nations' overall happiness (Pratt et al., 2016). Pratt et al. argue that economic indicators do not affect happiness of the residents, but emotional indicators do. More specifically, life satisfaction is a combination of psychological wellbeing, time use, community vitality, cultural diversity, ecological resilience, living standard, health, education, and good governance (Pratt et al., 2016).

Happiness is the basis for quality of life formation and can be perceived differently because of the value of different dimensions within the concept. With the developmental stages, tourism changes from positive to negative and consequently affects a sense of happiness and life satisfaction of local residents. More specifically, tourism has an indirect relationship with quality of life, affecting various economic, socio-cultural and environmental attributes of the host community and thus aspects of locals' life (Rivera et al., 2016), for some in a positive but for others in a negative way (Lee, 2013; Stylidis et al., 2014). Understanding hosts' perceived satisfaction with life is an essential driver 
of tourism development, at the operational and policy level. More specifically, when seeking hosts' support and insights into the directions of tourism development, policy makers must understand how the local population perceives tourism and its impacts on their satisfaction with life. Using such an approach, tourism policy makers and destination organizations have the best possible starting point for preventing negative impacts of tourism and maximizing its benefits, thus achieving greater support for local residents (Prayag et al., 2013; Stylidis et al., 2014). At the operational level, the tourism industry should understand how locals feel about tourism for successful development of socially responsible tourism operations.

Individuals perceive tourism in a subjective way, according to their emotions and living environment. Areas that encompass the everyday life of residents, and acceptance of them, are shaped into a quality of life that is also heavily influenced by different levels of tourism development. More specifically, various levels of tourism development influence levels of residents' interaction with tourists, their involvement and dependence on tourism as well as access to tourismrelated infrastructure and leisure opportunities (Murphy, 1985).

The most adopted approach to study destination tourism development was proposed by Butler (1980). The Tourism Area Life Cycle (TALC) is used in attempts to understand the process of the development of tourist destinations in a wide variety of settings (Butler, 2006). The model originally hypothesized six stages of destinations development based on a number of indicators; for example, number of tourists, visitation growth over certain time, accommodation occupancy rate, number of beds, tourists per capita expenditure and similar (Uran Maravić \& Juvan, 2009). Although the model has been widely adopted and referenced in many academic and professional resources (Ho \& McKercher, 2015) it is assumed that most of the empirical evidence is of limited validity. Nevertheless, the model is still a valid approach in defining the development stage of a tourism destination for various reasons, including policy making, strategic development and even scientific purposes (Ho \& McKercher, 2015). As per the authors' best knowledge, no attempt has been made so far to classify Slovenian tourism destinations using the TALC model; however, a few publications have touched the different stages of tourism development in Slovenia (for example, Uran Maravić \& Juvan, 2009).

This literature review allows concluding that (1) the impact of tourism development plays an important role in the emotional aspects of the host's life satisfaction. Overall, research shows that tourism has a positive and negative impact; (2) not all residents perceive similar impacts of tourism - those who benefit directly from tourism through employment are likely to be better supporters and report higher levels of satisfaction with different aspects of life than residents with no specific connection to tourism; and (3) the level of positive emotions depends on the level of tourism development; predictably people are happier and more satisfied with life in cities with early stages of tourism development (Uysal et al., 2016).

Following the theoretical implications of the relations between different stages of tourism development and the quality of life discussed above, we hypothesize the following:

$\mathrm{H} 1$ Level of tourism development predicts residents' satisfaction with life.

$\mathrm{H} 2$ Interaction with tourists predicts residents' satisfaction with life.

$\mathrm{H} 3$ Level of tourism development predicts residents' emotional wellbeing.

$\mathrm{H} 4$ Interaction with tourists predicts residents' emotional wellbeing.

\section{Methodology}

The quantitative approach was adopted to test the proposed hypotheses. Data was collected via an online survey tool $1 \mathrm{KA}$, using a survey questionnaire. The survey was distributed among survey participants using a snowball sampling technique (for example, participants who completed the survey were asked to recommend participation to their peers) and gatekeepers were typically well-known and networked within observed destinations (for example, local tourist information centres, local societies and social clubs). The survey involved participants living in three dif- 
ferent municipalities in Slovenia, with different levels of tourism development.

The survey measured several aspects of life with the following being an interest of the current study:

- Satisfaction with life (Pratt et al., 2016) was measured using a 5-point Likert-type scale (1 - not satisfied at all, and 5 - completely satisfied) for six different aspects of life: health, life standard, work, family relations, balance between work and free time, and relationships with members of the community. Dependent variable satisfaction with life was factor analysed for further regression analysis with hypothesized predictors. Pearson's correlational coefficients were computed to detect multicollinearity and check for internal validity and Cronbach's Alpha was used to assess the reliability. The results show there are statistically significant (at the 0.05 level) correlations among the pairs of indicators of satisfaction with life, suggesting a high level of internal validity; correlational coefficients $f 0.491$ or lower indicate acceptable multicollinearity. The value of the Cronbach Alpha of 0.739 shows an acceptable reliability (George \& Mallery, 2003).

- Emotional wellbeing (Pratt et al., 2016) was measured for the frequency of experiencing three negative (fear, anxiety, depression) and three positive (calmness, contentment, and pleasure) emotions. Participants were asked to express the frequency of experiencing emotions using four categories of answers (frequently, sometimes, rarely and never). To keep the survey instrument as short as possible and thus avoiding respondent fatigue (Dolnicar et al., 2011), the original set of emotions from Pratt et al. (2016) were reduced to six emotions in total. This procedure was done using a qualitative pre-study involving 23 participants. Participants, randomly intercepted in public areas of researched communities, were asked to list three positive and three negative emotions which they remember experiencing most frequently. The emotions most frequently mentioned by interviewees were included in the quantitative survey.
Table 1 Key Tourism Area Life Cycle Indicators for the Observed Destinations

\begin{tabular}{rrrrrrr}
\hline Year/destination & $(1)$ & $(2)$ & $(3)$ & $(4)$ & $(5)$ \\
\hline 2015 & D 1 & 445392 & 1408790 & 14493 & 25.00 & 10294 \\
& D2 & 169 & 51847 & 909 & 0.51 & 780 \\
& D3 & 4603 & 8113 & 237 & 0.21 & 221 \\
\hline 2016 & D 1 & 480736 & 1507890 & 14446 & 27.00 & 11079 \\
& D2 & 25422 & 51649 & 735 & 0.52 & 786 \\
& D3 & 5065 & 7821 & 212 & 0.24 & 225 \\
\hline 2017 & D 1 & 534874 & 1649251 & 14734 & 30.00 & 12279 \\
& D2 & 28202 & 55558 & 758 & 0.58 & 816.6 \\
& D3 & 5156 & 8499 & 161 & 0.24 & 225.8 \\
\hline \multirow{2}{*}{2017} & D1 & 604592 & 1882383 & - & 34.00 & 13827 \\
& D2 & 30855 & 64096 & - & 0.62 & 846 \\
& D3 & 6563 & 13574 & - & 0.30 & 238 \\
\hline
\end{tabular}

Notes Column headings are as follows: (1) arrivals, (2) overnights, (3) beds, (4) T/R, (5) people per $\mathrm{m}^{2}$.

- Level of tourism development was assessed as an objective measurement of tourism development using the TALC tourism development model, with a number of TALC indicators for three observed destinations. More specifically, following recommendations from Uran Maravić and Juvan (2009), we observed tourist arrivals, number of nights, number of beds, number of tourists per local resident and number of people per square meter of land (see Table 1). Given that no empirical evidence exists on the threshold of different TALC indicators specific for the particular TALC stage it was impossible to determine the actual TALC stage for the observed destinations. However, empirical indicators of tourism development allowed the arbitrary decision to split the three communities into two extremely different TALC stages: the high and low level of tourism development. The destination with high TALC is in the later stages of tourism development, and the destination with low TALC is in the earlier stages of tourism development. While the selected dimensions of tourism development are not exhaustive, they do indicate the level of tourism development (e.g. Buttler, 1980) and may 
affect residents' emotional wellbeing and satisfaction with life (Pratt et al., 2016).

- Interaction with tourists was measured as a subjective and objective measurement. Subjectively, the interaction with tourists was assessed by asking participants about the perceived extent of their interaction with tourists in the last 2 years. Responses were captured on a numerical scale with endpoints labelled o - no interaction with tourists at all and $100-$ a lot of interaction with tourists. Respondents from high TALC ( $\mathrm{M}=$ $76.87, \mathrm{SD}=25.06)$ report significantly $(t(546)=$ -14.352, $p<0.001$ ) higher levels of interaction with tourists than their counterparts from low TALC $(M=44.05, S D=28.50)$. Objectively, this concept was measured by asking respondents whether or not they work in the tourism industry. Responses were captured with binary categorical measure (yes, no). Significantly more $\left(X^{2}(1)=82.393, p=0.000\right)$ respondents from high TALC work in tourism. Given the aim of the study, to determine the association between the interaction with tourists and satisfaction with life and emotional wellbeing, we limited ourselves to the quantitative dimensions of interaction with tourists as strong factors of hosts' satisfaction with life (Murphy, 1985; Perdue et al., 1990).

- In addition, a number of socio-demographic characteristics were measured using categorical (for example, education was measured with four response options: elementary school or less, vocational or high school education, college or university degree, postgraduate degree) or with ordinal scale (for example, length of living at the destination was measured with the following response options: less than a year, from 1 to 5 years, from 5 to 10 years, more than 10 years).

Overall, 627 valid surveys were completed (see Tables 2 and 3), of which 295 (47\%) are from the destination in a consolidated TALC stage and 332 (53\%) from that in the involvement TALC stage. $71 \%$ of the final sample are female participants and between 16 and 90 years old $(\mathrm{M}=39.53, \mathrm{SD}=14.3)$. The majority $(79 \%)$ of respondents have lived in their respective destina-
Table 2 Sample Characteristics: Categorical Variables

\begin{tabular}{llrr}
\hline Category & Item & $f$ & $f(\%)$ \\
\hline Gender & Male & 145 & 29.4 \\
& Female & 348 & 70.6 \\
\hline Destination & High TALC & 295 & 47.0 \\
& Low TA LC & 332 & 53.0 \\
\hline Highest level & Elementary school or less & 20 & 4.1 \\
of education & Voc. school, high school & 137 & 49.0 \\
& College, university degree & 195 & 40.3 \\
& Postgraduate degree & 32 & 6.6 \\
\hline Working in the & Yes & 102 & 37.9 \\
tourism sector & No & 167 & 62.1 \\
\hline
\end{tabular}

Table 3 Sample Characteristics: Scale Variables

\begin{tabular}{lrrr}
\hline Item & Valid & 496 & 482 \\
\hline$N$ & Missing & 131 & 145 \\
\hline Mean & 39.530 & 3.620 \\
Stdandard deviation & 14.392 & 0.802 \\
Skewness & 0.458 & - \\
Std. error of skewness & & 2.040 \\
Kurtosis & 0.110 & 0.111 \\
Std. error of kurtosis & -0.397 & 2.968 \\
\hline Minimum & 0.219 & 0.222 \\
Maximum & 16 & 1 \\
\hline Notes Column headings are as follows: (1) & 90 & 4 \\
\hline
\end{tabular}

Notes Column headings are as follows: (1) age, (2) length of living at the destination.

tion for more than 10 years. Almost half of respondents (49\%) have completed vocational or a higher level of education, and $40.3 \%$ of participants completed college or a university degree. On average, $(M=59.77$; $\mathrm{SD}=31.5)$ respondents perceive themselves to have a moderate level of interactions with tourists. Research hypotheses were tested using the regression analysis.

\section{Results}

This section provides empirical testing of the research hypotheses, beginning with a descriptive presentation of the key dimensions of satisfaction with life. 
Table 4 Descriptive Statistics on Dimensions of Satisfaction with Life

\begin{tabular}{lrrrrrrr}
\hline TALC & & $(1)$ & $(2)$ & $(3)$ & $(4)$ & $(5)$ & $(6)$ \\
\hline Low & (a) & 3.73 & 3.53 & 3.50 & 3.96 & 3.50 & 3.66 \\
& (b) & 264 & 253 & 251 & 253 & 252 & 253 \\
& (c) & 1.252 & 1.015 & 0.490 & 1.548 & 0.094 & 1.083 \\
& (d) & -1.151 & -0.911 & -0.838 & -1.155 & -0.562 & -0.961 \\
& (e) & 0.061 & 0.054 & 0.062 & 0.059 & 0.060 & 0.057 \\
\hline High & (a) & 3.74 & 3.35 & 3.49 & 4.15 & 3.41 & 3.69 \\
& (b) & 239 & 232 & 231 & 231 & 232 & 232 \\
& (c) & 1.378 & 0.108 & 0.086 & 2.455 & -0.336 & 0.630 \\
& (d) & -1.197 & -0.662 & -0.496 & -1.395 & -0.513 & -0.524 \\
& (e) & 0.065 & 0.064 & 0.064 & 0.060 & 0.071 & 0.051 \\
\hline Total & (a) & 3.74 & 3.44 & 3.50 & 4.05 & 3.45 & 3.67 \\
& (b) & 503 & 485 & 482 & 484 & 484 & 485 \\
& (c) & 1.287 & 0.501 & 0.282 & 1.862 & -0.119 & 1.040 \\
& (d) & -1.170 & -0.794 & -0.674 & -1.250 & -0.550 & -0.816 \\
& (e) & 0.045 & 0.042 & 0.044 & 0.043 & 0.046 & 0.038 \\
\hline
\end{tabular}

Notes Column/row headings are as follows: (1) health, (2) living standard, (3) work, (4) family relations, (5) balance of work and free time, (6) community relations, (a) mean, (b) $N$, (c) kurtosis, (d) skewness, (e) standard error of mean.

\section{Satisfaction with Life}

Results show (see Table 4) that, on average, respondents are satisfied with family relations $(M=4.05$; SD $=0.935)$, health $(M=3.74 ; \mathrm{SD}=1.002)$ and relationships with members of the community $(M=3.67$; SD $=0.847)$. On average, respondents are neither satisfied nor dissatisfied with work $(M=3.5 ; \mathrm{SD}=0.976)$, balance between work and free time $(M=3.45$; SD = 1.021) and life standard $(M=3.44 ; \mathrm{SD}=0.92)$. In all cases, skewness and kurtosis fall in the interval $|-2 ; 2|$, suggesting a distribution close to a normal one. All the indicators of satisfaction with life were kept for further statistical analysis.

In the following, the Pearson's correlational coefficients were computed (see Table 5), in order to detect multicollinearity and check for internal validity. The results show there are statistically significant (at the 0.05 level) correlations among the pairs of indicators of satisfaction with life, suggesting a high level of internal validity. Since the highest correlational coefficient is 0.491 , there is no evidence of multicollinearity.

The Cronbach Alpha coefficient was computed, in order to check for reliability. The value of the Cronbach Alpha is 0.739 , showing a reliable research instrument in the case of satisfaction with life.

Factor analysis with principal axis factoring was conducted to linearly reduce the number of dimensions of satisfaction with life. The computed communalities (see Table 6) have high extraction scores (> $|0.3|$ ) for life standard, work and balance between work and free time. For other indicators the extraction scores fall slightly outside the interval, but communalities support keeping them as indicators of satisfaction with life. The factor analysis (principal axis factoring) suggests a single factor solution with the initial eigenvalue higher than 1 (2.623). The one-factor solution explains $43.722 \%$ of total variance (see Table 7 ). The factor matrix (see Table 8) supports the one-factor solution, since all the factor scores are higher than $|0.3|$, confirming a high importance of the indicator on the factor. The suggested one-factor solution was kept for further statistical analysis.

Research hypotheses $\mathrm{H} 1$ and $\mathrm{H} 2$ were tested using the regression analysis. Results (see Table 9) show no statistically significant association (at the 0.05 level) between TALC and/or number of interactions with tourists and satisfaction with life. The determination coefficient is 0.004 . The regression model is not statistically significant $(F=0.283$; sig. $=0.838)$.

\section{Emotional Wellbeing}

Over half of respondents (see Table 10) often feel calmness $(54.7 \%$ of respondents) and contentment $(58.9 \%$ of respondents), but a third of respondents feel the two emotions only sometimes $35.3 \%$ for calmness and $34.4 \%$ for contentment). $44.7 \%$ of respondents feel pleasure often and $45.1 \%$ of them feel pleasure sometimes. Regarding the negative emotions, the majority feels them rarely (fear $45.6 \%$ of respondents and depression $47.6 \%$ of respondents) or sometimes ( $46.7 \%$ in the case of anxiety). All the indicators of psychological wellbeing were kept for further statistical analysis.

Regression analysis (see Table 11) was performed to test statistically significant relations between the 
Table 5 Pearson's Correlational Coefficients among Indicators of Satisfaction with Life

\begin{tabular}{|c|c|c|c|c|c|c|c|}
\hline Factor & & (1) & (2) & (3) & (4) & (5) & (6) \\
\hline \multirow[t]{3}{*}{ (1) Health } & Pearson correlation & 1 & $0.361^{\star *}$ & $0.374^{\star *}$ & $0.264^{\star *}$ & $0.222^{\star *}$ & $0.290^{* *}$ \\
\hline & Sig. (2-tailed) & & 0.000 & 0.000 & 0.000 & 0.000 & 0.000 \\
\hline & $N$ & 503 & 485 & 481 & 484 & 484 & 485 \\
\hline \multirow[t]{3}{*}{ (2) Living standard } & Pearson correlation & $0.361^{\star *}$ & 1 & $0.491^{\star *}$ & $0.275^{* *}$ & $0.359^{* *}$ & $0.280^{\star *}$ \\
\hline & Sig. (2-tailed) & 0.000 & & 0.000 & 0.000 & 0.000 & 0.000 \\
\hline & $N$ & 485 & 485 & 480 & 481 & 481 & 482 \\
\hline \multirow[t]{3}{*}{ (3) Work } & Pearson correlation & $0.374^{* *}$ & $0.491^{\star *}$ & 1 & $0.277^{\star *}$ & $0.430^{* *}$ & $0.300^{* *}$ \\
\hline & Sig. (2-tailed) & 0.000 & 0.000 & & 0.000 & 0.000 & 0.000 \\
\hline & $N$ & 481 & 480 & 482 & 479 & 480 & 480 \\
\hline \multirow[t]{3}{*}{ (4) Family relations } & Pearson correlation & $0.264^{* *}$ & $0.275^{* *}$ & $0.277^{* *}$ & 1 & $0.249^{\star *}$ & $0.320^{* *}$ \\
\hline & Sig. (2-tailed) & 0.000 & 0.000 & 0.000 & & 0.000 & 0.000 \\
\hline & $N$ & 484 & 481 & 479 & 484 & 482 & 483 \\
\hline \multirow[t]{3}{*}{ (5) Work and free time balance } & Pearson correlation & $0.222^{\star *}$ & $0.359^{\star *}$ & $0.430^{* *}$ & $0.249^{\star *}$ & 1 & $0.332^{* *}$ \\
\hline & Sig. (2-tailed) & 0.000 & 0.000 & 0.000 & 0.000 & & 0.000 \\
\hline & $N$ & 484 & 481 & 480 & 482 & 484 & 484 \\
\hline \multirow[t]{3}{*}{ (6) Community relations } & Pearson correlation & $0.290^{* *}$ & $0.280^{* *}$ & $0.300^{\star *}$ & $0.320^{* *}$ & $0.332^{\star *}$ & 1 \\
\hline & Sig. (2-tailed) & 0.000 & 0.000 & 0.000 & 0.000 & 0.000 & \\
\hline & $N$ & 485 & 482 & 480 & 483 & 484 & 485 \\
\hline
\end{tabular}

Notes $\quad * *$ Sig. $<0.01$.

Table 6 Communalities in Factor Analysis, for Indicators of Satisfaction with Life

\begin{tabular}{lcr}
\hline Factor & Initial & Extrac. \\
\hline Health & 0.220 & 0.281 \\
Living standard & 0.312 & 0.416 \\
Work & 0.359 & 0.491 \\
Family relations & 0.167 & 0.211 \\
Work and free time balance & 0.253 & 0.315 \\
Community relations & 0.208 & 0.261 \\
\hline
\end{tabular}

Notes Extraction method: Principal axis factoring.

level of tourism development and interaction with tourists and emotional wellbeing. Results suggests that tourism development as well as interaction with tourists have no significant relationship with a particular emotion; the percentage of the explained variance is very low (between 0.3 and 2.2). All the regres-
Table 7 Total Variance Explained with Factor Analysis, for Indicators of Satisfaction with Life

\begin{tabular}{|c|c|c|c|c|c|c|}
\hline \multirow[t]{2}{*}{ Factor } & \multicolumn{3}{|c|}{ Initial eigenvalues } & \multicolumn{3}{|c|}{ Extraction sums ${ }^{\star}$} \\
\hline & (1) & (2) & (3) & (1) & (2) & (3) \\
\hline 1 & 2.623 & $43 \cdot 722$ & 43.722 & 1.975 & 32.914 & 32.914 \\
\hline 2 & 0.847 & 14.111 & 57.833 & & & \\
\hline 3 & 0.787 & 13.116 & 70.949 & & & \\
\hline 4 & 0.685 & 11.418 & 82.367 & & & \\
\hline 5 & 0.568 & 9.474 & 91.842 & & & \\
\hline 6 & 0.489 & 8.158 & 100.000 & & & \\
\hline
\end{tabular}

sion models are not statistically significant at the 0.05 level. There is no evidence of any statistically significant impact (at the 0.05 level) of the level of tourism development or interaction with tourists on residents' emotional wellbeing.

Finally, the overall regression model (ENTER meth- 
Table 8 Factor Matrix, for Satisfaction with Life

\begin{tabular}{ll}
\hline Factor & Value \\
\hline Health & 0.530 \\
Living standard & 0.645 \\
Work & 0.700 \\
Family relations & 0.459 \\
Work and free time balance & 0.561 \\
Community relations & 0.511 \\
\hline
\end{tabular}

Notes Extraction method: Principal axis factoring. 1 factor extracted, 6 iterations required.

Table 9 Associations between Satisfaction with Life, Level of Tourism Development and Interaction with Tourists

\begin{tabular}{lrrrrr}
\hline Item & $B$ & $\mathrm{SE}$ & $\beta$ & $t$ & Sig. \\
\hline (Constant) & 0.109 & 0.336 & & 0.324 & 0.746 \\
TALC & 0.014 & 0.144 & 0.008 & 0.097 & 0.923 \\
Work in tourism & 0.039 & 0.146 & 0.022 & 0.265 & 0.791 \\
Interac. with tourists & -0.001 & 0.002 & -0.049 & -0.578 & 0.563 \\
\hline
\end{tabular}

Notes Dependent variable: Satisfaction with life (factor).

od) was computed where Satisfaction with life is used as the dependent variable and other concepts as predictors. The results (see Table 12) show that the regression model explains $25.8 \%$ of the total variance in Satisfaction with life. The model's fit is good ( $F=$ 6.432; sig. < 0.001). Statistically significant (at the 0.05 level) regression coefficients suggest that contentment $(\beta=-0.174$; sig. $=0.03)$, pleasure $(\beta=-0.181$; sig. $=$ $0.019)$ and the highest level of education $(\beta=0.247$; sig. < 0.001) significantly predict satisfaction with life. The local residents that more often feel contentment and pleasure and have a higher level of education are more satisfied with life compared to their counterparts who never feel contentment and pleasure, and have a lower level of education. The hypothesized prediction of tourism development and interaction with tourists indicates no significant direct association with residents' emotional wellbeing or satisfaction with life.

\section{Findings and Conclusion}

Ensuring residents' emotional wellbeing and satisfaction with life is an important indicator of sustainable
Table 10 Descriptive Statistics on Emotional Wellbeing at Destinations with Different Levels of Tourism Development

\begin{tabular}{|c|c|c|c|c|c|}
\hline \multirow[t]{2}{*}{ Emotion } & \multirow[t]{2}{*}{ Item } & & \multicolumn{2}{|c|}{ TALC } & \multirow[t]{2}{*}{ Total } \\
\hline & & & Low & High & \\
\hline \multirow[t]{8}{*}{ Calmness } & Often & (a) & 141 & 144 & 285 \\
\hline & & (b) & 51.1 & 58.8 & 54.7 \\
\hline & Sometimes & (a) & 105 & 79 & 184 \\
\hline & & (b) & 38.0 & 32.2 & 35.3 \\
\hline & Rarely & (a) & 30 & 22 & 52 \\
\hline & & (b) & 10.9 & 9.0 & 10.0 \\
\hline & Total & (a) & 276 & 245 & 521 \\
\hline & & (b) & 100.0 & 100.0 & 100.0 \\
\hline \multirow[t]{10}{*}{ Contentment } & Often & (a) & 158 & 133 & 291 \\
\hline & & (b) & 59.8 & 57.8 & 58.9 \\
\hline & Sometimes & (a) & 89 & 81 & 170 \\
\hline & & (b) & 33.7 & 35.2 & 34.4 \\
\hline & Rarely & (a) & 16 & 16 & 32 \\
\hline & & (b) & 6.1 & 7.0 & 6.5 \\
\hline & Never & (a) & 1 & o & 1 \\
\hline & & (b) & 0.4 & 0.0 & 0.2 \\
\hline & Total & (a) & 264 & 230 & 494 \\
\hline & & (b) & 100.0 & 100.0 & 100.0 \\
\hline \multirow[t]{10}{*}{ Enjoyment } & Often & (a) & 115 & 106 & 221 \\
\hline & & (b) & 44.1 & 45.5 & $44 \cdot 7$ \\
\hline & Sometimes & (a) & 125 & 98 & 223 \\
\hline & & (b) & 47.9 & 42.1 & 45.1 \\
\hline & Rarely & (a) & 20 & 28 & 48 \\
\hline & & (b) & $7 \cdot 7$ & 12.0 & 9.7 \\
\hline & Never & (a) & 1 & 1 & 2 \\
\hline & & (b) & 0.4 & 0.4 & 0.4 \\
\hline & Total & (a) & 261 & 233 & 494 \\
\hline & & (b) & 100.0 & 100.0 & 100.0 \\
\hline
\end{tabular}

Continued in the next column

development, because it seeks to maintain the psychological capacity of the destination (Mowforth \& Munt, 2003) and because satisfied and happy residents may become an important destinations attribute for tourism marketing (Pyke et al., 2016). It is widely ac- 
Table 10 Continued from the previous column

\begin{tabular}{|c|c|c|c|c|c|}
\hline \multirow[t]{2}{*}{ Emotion } & \multirow[t]{2}{*}{ Item } & & \multicolumn{2}{|c|}{ TALC } & \multirow[t]{2}{*}{ Total } \\
\hline & & & Low & High & \\
\hline \multirow[t]{10}{*}{ Fear } & Often & (a) & 33 & 18 & 51 \\
\hline & & (b) & 12.7 & 7.8 & 10.4 \\
\hline & Sometimes & (a) & 81 & 73 & 154 \\
\hline & & (b) & 31.2 & 31.6 & 31.4 \\
\hline & Rarely & (a) & 122 & 102 & 224 \\
\hline & & (b) & 46.9 & 44.2 & 45.6 \\
\hline & Never & (a) & 24 & 38 & 62 \\
\hline & & (b) & 9.2 & 16.5 & 12.6 \\
\hline & Total & (a) & 260 & 231 & 491 \\
\hline & & (b) & 100.0 & 100.0 & 100.0 \\
\hline \multirow[t]{10}{*}{ Worry } & Often & (a) & 41 & 31 & 72 \\
\hline & & (b) & 16.0 & 13.4 & 14.8 \\
\hline & Sometimes & (a) & 112 & 116 & 228 \\
\hline & & (b) & 43.6 & 50.2 & 46.7 \\
\hline & Rarely & (a) & 92 & 77 & 169 \\
\hline & & (b) & 35.8 & $33 \cdot 3$ & 34.6 \\
\hline & Never & (a) & 12 & 7 & 19 \\
\hline & & (b) & $4 \cdot 7$ & 3.0 & 3.9 \\
\hline & Total & (a) & 257 & 231 & 488 \\
\hline & & (b) & 100.0 & 100.0 & 100.0 \\
\hline \multirow[t]{10}{*}{ Sadness } & Often & (a) & 19 & 7 & 26 \\
\hline & & (b) & $7 \cdot 4$ & 3.0 & $5 \cdot 3$ \\
\hline & Sometimes & (a) & 80 & 69 & 149 \\
\hline & & (b) & 31.0 & 29.7 & 30.4 \\
\hline & Rarely & (a) & 117 & 116 & 233 \\
\hline & & (b) & $45 \cdot 3$ & 50.0 & 47.6 \\
\hline & Never & (a) & 42 & 40 & 82 \\
\hline & & (b) & 16.3 & 17.2 & 16.7 \\
\hline & Total & (a) & 258 & 232 & 490 \\
\hline & & (b) & 100.0 & 100.0 & 100.0 \\
\hline
\end{tabular}

Notes (a) Count, (b) percentage within TALC.

cepted that vacations add to one's quality of life but links between tourism development and hosts' satisfaction with life remains unclear. The present study aims at adding empirical evidence about the links be-
Table 11 Association between Emotional Wellbeing, Level of Tourism Development and Interaction with Tourists

\begin{tabular}{|c|c|c|c|c|c|}
\hline & $R^{2}$ & $F$ & Sig. & (1) & (2) \\
\hline Calmness & 0.018 & 1.556 & 0.201 & $\begin{array}{l}-0.033 \\
(0.694)\end{array}$ & $\begin{array}{c}0.0120 .157 \\
(0.883)(0.059)\end{array}$ \\
\hline Contentment & 0.011 & 0.875 & 0.455 & $\begin{array}{c}0.134 \\
(0.108)\end{array}$ & $\begin{array}{c}0.050-0.058 \\
(0.536)(0.484)\end{array}$ \\
\hline Enjoyment & 0.022 & 1.854 & 0.138 & $\begin{array}{c}0.143 \\
(0.087)\end{array}$ & $\begin{array}{c}0.147-0.062 \\
(0.074)(0.460)\end{array}$ \\
\hline Fear & 0.008 & 0.630 & 0.596 & $\begin{array}{c}0.079 \\
(0.348)\end{array}$ & $\begin{array}{c}0.053-0.076 \\
(0.517)(0.369)\end{array}$ \\
\hline Worry & 0.017 & 1.378 & 0.250 & $\begin{array}{c}0.059 \\
(0.478)\end{array}$ & $\begin{array}{c}0.000-0.155 \\
(0.997)(0.067)\end{array}$ \\
\hline Sadness & 0.003 & 0.258 & 0.855 & $\begin{array}{c}0.000 \\
(1.000)\end{array}$ & $\begin{array}{c}0.025-0.039 \\
(0.765)(0.641)\end{array}$ \\
\hline
\end{tabular}

Notes Column headings are as follows: (1) TALC $\beta$, (2) interaction with tourists, (3) working in tourism; $p$-vales in parenthesis.

Table 12 Overall Regression Model for Satisfaction with Life

\begin{tabular}{lrrrrr}
\hline Item & $B$ & $\mathrm{SE}$ & $\beta$ & $t$ & Sig. \\
\hline (Constant) & -1.138 & 0.583 & -1.953 & 0.052 \\
TALC & 0.092 & 0.133 & 0.054 & 0.689 & 0.491 \\
Working in tourism & -0.003 & 0.133 & -0.002 & -0.021 & 0.983 \\
Interac. with tourists & -0.001 & 0.002 & -0.040 & -0.499 & 0.619 \\
Calmness & 0.037 & 0.089 & 0.029 & 0.419 & 0.676 \\
Contentment & -0.258 & 0.118 & -0.174 & -2.184 & 0.030 \\
Enjoyment & -0.235 & 0.100 & -0.181 & -2.364 & 0.019 \\
Fear & 0.105 & 0.080 & 0.099 & 1.315 & 0.190 \\
Worry & 0.153 & 0.092 & 0.128 & 1.654 & 0.100 \\
Sadness & 0.011 & 0.080 & 0.009 & 0.132 & 0.895 \\
Gender & 0.131 & 0.115 & 0.070 & 1.139 & 0.256 \\
Age & 0.005 & 0.005 & 0.054 & 0.903 & 0.367 \\
Highest educ. level & 0.327 & 0.082 & 0.247 & 3.966 & 0.000 \\
\hline
\end{tabular}

Notes Dependent variable: Satisfaction with life (factor).

tween tourism and residents' emotional wellbeing and satisfaction with life. Following the theoretical background and previous empirical research, four research hypotheses were tested. First, we hypothesized that 
the level of tourism development predicts residents' perceived level of satisfaction with life. The analysis section does not allow accepting this hypothesis because no significant association was identified between self-reported satisfaction with life and the level of tourism development. This study empirically assessed the satisfaction with six different aspects of life at destinations with different levels of tourism development. The city with high TALC is actually a rather small coastal city where locals can hardly avoid interaction with tourists. On the other hand, cities with low TALC are larger in area and have a substantially lower population (tourists and locals) per square meter; hence, it is hard to detect crowds, and tourists in particular, as well as tourism infrastructure and experiences. This finding challenges the prevailing assumption that higher levels of tourism by default lead to lower satisfaction with life of local residents and their low emotional wellbeing. Given that it is the interaction with tourists which may play a higher role in life satisfaction rather than the level of tourism development, we tested how interaction with tourists, at the subjective and objective level, predicts life satisfaction. Again, this study finds no statistically significant association between the two. The finding that no significant association exists between employment in tourism and satisfaction with life is extremely interesting. Employment in tourism brings at least economic benefits, hence some link to satisfaction with life should exist; especially given that residents working in tourism are more likely in support of tourism than those not working in this industry (McGehee \& Andereck, 2004). Nevertheless, it may be that results are very context dependent and that other factors (for example, emotions, family cycle) cause the gap between levels of tourism development and satisfaction with life, which would call for more research into the two concepts.

Secondly, we hypothesize (using separate hypotheses) that residents' emotional wellbeing depends on the level of tourism development and residents' interaction with tourism. Both hypotheses must be rejected, as empirical results demonstrate no significant association between the concepts. The two hypotheses followed the premises (1) that working in tourism is extremely demanding, which influences one's life satisfaction (Baum, 2007) and (2) higher level of interaction with tourists should affect (negatively) one's feeling of calmness or even fear (Peeters et al., 2018). The context in which the present study took place does not allow accepting this hypothesis, but the data also does not provide insights into why interaction with tourists does not affect any of the most typically experienced emotions. It is well accepted that a higher level of tourism development leads to less favourable residents' attitudes towards tourism (for example, Murphy, 1985; Teye et al., 2002); the present study demonstrates that the same logic does not hold for emotions or satisfaction with life.

Education, as a socio-demographic characteristic, and feelings of enjoyment and contentment as elements of emotional wellbeing are the only three significant predictors of residents' satisfaction with life. This finding challenges previous empirical insights about the negative impacts of tourism on local residents' satisfaction with life and emotional wellbeing. There exists the possibility that even in a context with a high level of tourism development, local residents may still have a chance to isolate themselves from tourism, thus preventing tourism from negatively impacting their everyday life. Empirical findings show that, irrespective of the perceived level of interaction with tourists, residents report similar levels of satisfaction with life. Interaction with tourists was measured as a subjective (perceived level of interaction) and objective (working in tourism industry) measurement, but results of this study show that neither significantly adds to nor reduces the level of life satisfaction.

Although emotions appear less frequently associated with tourism, they are the basis for expression of individuals and an important factor in creating satisfaction for both hosts and guests. A high level of satisfaction is the foundation for happiness, and because tourism is recognized as a means of generating happiness (Pearce et al., 2011) it is reasonable to interpret tourism as a tool for achieving happiness for tourists as well as residents. However, our study points out that the existing believed association of tourism and life satisfaction and emotional wellbeing cannot be generalized across different contexts or even cultures. 
Tourism success is measured beyond typical income and arrivals numbers, which echoes the principles of sustainable yield. By creating a welcoming atmosphere, locals contribute to a positive tourism experience but they only can do this if they themselves feel satisfied and happy. Quality of life has to be maintained, with special attention given to improvements, with a view to achieving mutual effect; quality of life of local residents and tourists. Interweaving good relationships, coherence and careful planning is the key to successful, healthy tourism development that complements the lives of locals. The empirical findings of this study are somewhat surprising, given that the emotional wellbeing and satisfaction were measured at destinations with extremely opposite levels of tourism development. Nevertheless, findings do reflect current understanding that achieving social sustainability is context dependent (Font \& McCabe, 2017) and that research is needed around quality of life and tourism (Liburd et al., 2012). We hope that the present study has shed more light on the aspects of social sustainability, as a concept involving residents' emotional wellbeing and satisfaction with life, and their dependence on different contexts.

Practically, this study contributes to the body of knowledge on managing residents' emotional wellbeing and satisfaction with life. We empirically highlight that feelings of contentment and enjoyment act as drivers of satisfaction with life, dependent on the level of tourism development. Destination organizations and tourism providers should monitor the levels of contentment and enjoyment as well as investigate which aspects of tourism lead to higher levels of the two emotions. In addition, when assuring high levels of contentment and enjoyment, these two emotions should be used as destination attributes marketed to the tourists. Marketing campaigns must demonstrate that locals are content and enjoy their lives at the destination. In addition, a high level of education appears as a significant driver of life satisfaction and emotional wellbeing. This implies that tourism organizations should work with educational institutions to help build knowledge about tourism impacts at the destination to improve positive emotions about tourism and, finally, higher perceived satisfaction with life.
More research into dimensions of life satisfaction, emotional wellbeing and tourist interaction is needed to guide destination management policies and operations in ensuring social sustainability of tourism. Empirical findings in this study come by surprise and actually call for more specific studies into the levels or thresholds of interaction with tourists and its impact on residents' life satisfaction and emotional wellbeing. This would empirically determine how many and which kind of interactions with tourists are manageable or tolerable for the local population without sacrificing their satisfaction with life. While dimensions of interaction with tourism are beyond the scope of the current study, we believe it may play an important role in emotional wellbeing and satisfaction with life. Hence, future research should look into different context-destination specific dimensions of interaction with tourists and its role in hosts' emotional wellbeing and satisfaction with life, most likely, using a mixed method approach, where a qualitative approach would identify different dimensions and a quantitative approach would test the relevance and potential generalizability across similar destinations. This would improve the managerial ability of destination management organizations to benefit from emotional wellbeing and satisfaction with life of the local population.

\section{References}

Allport, G. W. (1961). Pattern and growth in personality. Holt, Rinehart \& Winston.

Baum, T. (2007). Human resources in tourism: Still waiting for change. Tourism Management, 28(6), 1383-1399.

Belisle, F. J., \& Hoy, D. R. (1980). The perceived impact of tourism by residents a case study in Santa Marta, Colombia. Annals of Tourism Research, 7(1), 83-101.

Buckley, R. (2011). Tourism and environment. Annual Review of Environment and Resources, 36, 397-416.

Butler, R. W. (1980). The concept of the tourist area life-cycle of evolution: Implications for management of resources. Canadian Geographer, 24(1), 5-12.

Butler, R. W. (2006). The origins of the tourism area life cycle. In R. W. Butler (Ed.), The tourism area life cycle (vol. 1, pp. 13-26). Channel View Publications.

Cummins, R. A. (1993). The comprehensive quality of life scale intellectual disability (4th ed.). Deakin University School of Psychology.

Dolnicar, S., Grün, B., \& Leisch, F. (2011). Quick, simple and 
reliable: Forced binary survey questions. International Journal of Market Research, 53(2), 231-252.

Dolnicar, S., Yamanadram, V., \& Cliff, K. (2012). The contribution of vacation to quality of life. Annals of Tourism Research, 39(1), 59-83.

Doxey, G. (1975). A causation theory of visitor-resident irritants: Methodology and research inferences; The impact of tourism. In The Sixth Annual Conference Proceedings of the Travel Research Association (pp. 195-198). The Travel Research Association.

Font, X., \& McCabe, S. (2017). Sustainability and marketing in tourism. Journal of Sustainable Tourism, 25(7), 869883.

George, D., \& Mallery, P. (2003). sPss for Windows step by step: A simple guide and reference, 11.0 update (4th ed.). Allyn \& Bacon.

Gholipour, H. F., Tajaddini, R., \& Nguyen, J. (2016). Happiness and inbound tourism. Annals of Tourism Research, $57(\mathrm{c}), 251-253$.

Gnoth, J. (1997). Tourism motivation and expectation formation. Annals of Tourism Research, 24(2), 283-304.

Ho, G. K. S., \& McKercher, B. (2015). A review of life cycle models by plog \& butler from a marketing perspective. In M. Kozak \& N. Kozak (Eds.), Destination marketing: An international perspective (pp. 145-154). Routledge.

Kahneman, D., \& Deaton, A. (2010). High income improves evaluation of life but not emotional well-being. PNAS, $7(38), 16489-16493$.

Kim, K., Uysal, M., \& Sirgy, M. J. (2013). How does tourism in a community impact the quality of life of community residents? Tourism Management, 36, 527-540.

Kubickova, M., Croes, R., \& Rivera, M. (2017). Human agency shaping tourism competitiveness and quality of life in developing economies. Tourism Management Perspectives, 22, 120-131.

Lee, T. H. (2013). Influence analysis of community resident support for sustainable tourism development. Tourism Management, 34, 37-46.

Liang, Z. X., \& Hui, T. K. (2016). Residents' quality of life and attitudes toward tourism development in China. Tourism Management, 57(7), 56-67.

Liburd, J. J., Benckendorff, P., \& Carlsen, J. (2012). Tourism and quality-of-life: How does tourism measure up? In M. Uysal, R. R. Perdue, \& M. J. Sirgy (Eds.), Handbook of tourism and quality of life research (pp. 105-132). Springer.

Lin, Y., Kerstetter, D., Nawijn, J., \& Mitas, O. (2014). Changes in emotions and their interactions with personality in a vacation context. Tourism Management, 40, 416-424.
McGehee, N., \& Andereck K. 2004. Factors predicting rural resident's support of tourism. Journal of Travel Research, 43(2), 131-140.

Mohit, M. A. (2014). Present trends and future directions of quality-of-life. Procedia: Social and Behavioral Sciences, $153,655-665$.

Mowforth, M., \& Munt, I. (2003). Tourism and sustainability: Development and new tourism in the third world (2nd ed.). Routledge.

Murphy, P. (1985). Tourism: A community approach. Routledge.

Pearce, P. L., Filep, S., \& Ross, G. (2011). Tourists, tourism and the good life. Routledge.

Peeters, P., Gössling, S., Klijs, J., Milano, C., Novelli, M., Dijkmans, C., Eijgelaar, E., Hartman, S., Heslinga, J., Isaac, R., Mitas, O., Moretti, S., Nawijn, J., Papp, B., \& Postma, A. (2018). Research for TRAN Committee-Overtourism: Impact and possible policy responses. European Parliament.

Perdue, R. R., Long, P. T., \& Allen, L. (1990). Resident support for tourism development. Annals of Tourism Research, 17(4), 586-599.

Pizam, A. (1978). Tourism's impacts: The social costs to the destination community as perceived by its residents. Journal of Travel Research, 16(4), 8-12.

Pratt, S., McCabe, S., \& Movono, A. (2016). Gross happiness of a 'tourism' village in Fiji. Journal of Destination Marketing and Management, 5(1), 26-35.

Prayag, G., Hosany, S., Nunkoo, R., \& Alders, T. (2013). London residents' support for the 2012 Olympic Games: The mediating effect of overall attitude. Tourism Management, 36(c), 629-640.

Pyke, S., Hartwell, H., Blake, A., \& Hemingway, A. (2016). Exploring well-being as a tourism product resource. Tourism Management, 55, 94-105.

Ribeiro, M. A., Pinto, P., Silva, J. A., \& Woosnam, K. M. (2017). Residents' attitudes and the adoption of protourism behaviours: The case of developing island countries. Tourism Management, 61, 523-537.

Rivera, M., Croes, R., \& Lee, S. H. (2016). Tourism development and happiness: A residents' perspective. Journal of Destination Marketing and Management, 5(1), 5-15.

Sharpley, R. (2014). Host perceptions of tourism: A review of the research. Tourism Management, 42, 37-49.

Sirgy, M. J., \&, Lee, D. J. (2006). Macro measures of consumer well-being: A critical analysis and research agenda. Journal of Macromarketing, 26(1), 27-44.

Stylidis, D., Biran, A., Sit, J., \& Szivas, E. M. (2014). Residents' support for tourism development: The role of 
residents' place image and perceived tourism impacts. Tourism Management, 45, 260-274.

Teye, V., Sonmez, S. F., \& Sirakaya, E. (2002). Residents' attitudes toward tourism development. Annals of Tourism Research, 29(3), 668-688.

Uran Maravić, M., \& Juvan, E. (2009). Strategije v turizmu: oblikovanje strategije turizma in vloga deležnikov. Društvo za akademske in aplikativne raziskave.

Uysal, M., Woo, E., \& Singal, M. (2012). The tourist area life cycle (TALC) and its effect on the quality-of-life (QOL) of destination community. In M. Uysal \& R. R. Perdue (Eds.), Handbook of tourism and quality-of-life research: Enhancing the lives (pp. 423-443). Springer.
Uysal, M., Sirgy, M. J., Woo, E., \& Kim, H. L. (2016). Quality of life (QOL) and well-being research in tourism. Tourism Management, 53, 244-261.

Williams, T. A. (1979). Impact of domestic tourism on holt population: The evolution of a model. Tourism Recreation Research, 4(2), 15-21.

World Tourism Organization. (2017). UNWTO tourism highlights: 2017 edition [Brochure].

World Tourism Organization. (2019). International tourism highlights: 2019 edition [Brochure]. 


\title{
Managers' Perspectives about the Relationship between Tourism and Climate Change: Case of the Republic of Croatia
}

\author{
Aleksandar Racz \\ University of Applied Health Sciences, Zagreb, Croatia \\ aleksandar.racz@zvu.hr \\ Dora Smolčić Jurdana \\ University of Rijeka, Faculty of Tourism and Hospitality Management, Croatia \\ doras@fthm.hr \\ Zvonimira Šverko Grdić \\ University of Rijeka, Faculty of Tourism and Hospitality Management, Croatia \\ zgrdic@fthm.hr
}

\begin{abstract}
Assuming a two-way relationship between climate change and tourism, it is very important to know the beliefs and attitudes of tourist managers. Research of beliefs and attitudes of tourist managers is a key problem of this research. Beliefs and attitudes of tourist managers are affected by different factors such as: sociodemographic characteristics, especially gender; level of education; length of service in the tourism sector; membership in ecological NGOs; and beliefs and attitudes about climate change. To investigate managers' opinions, the authors created a survey which focused on all managers who manage categorized facilities by type in the Republic of Croatia. The results have shown significant differences in the beliefs and attitudes about the interinfluence of climate change and tourist accommodation. Managers who are female, who have completed tertiary education, who are members of ecological NGOs and who consider themselves activists, and those who have more years of work experience, showed stronger pro-environmental attitudes and higher levels of ecological awareness.
\end{abstract}

Keywords: attitudes, beliefs, climate change, management, tourism, destinations

(cc)BY-SA https://doi.org/10.26493/2335-4194.14.53-70

\section{Introduction}

Climate change has become the biggest challenge and threat to the survival of human civilization, with many consequences for virtually every aspect of human life. There is a two-way relationship between tourism and climate change as tourism is largely dependent on the climate and is influenced by climate change in real time (Mahadew \& Appadoo, 2019).

It is estimated that tourism is the source of at least
$8 \%$ of global $\mathrm{CO}_{2}$ emissions which is why great efforts are being made on the global and national levels to mitigate the consequences of climate change (Wajahat et al., 2020). This also involves planning and taking measures to prevent further negative consequences that might become irreversible in the future (Kocak et al., 2020; Becken et al., 2020). Many authors agree that climate change originates in nature, 'but has causes in an economic, cultural and political system 
that is spreading around the world' (Ančić et al., 2016).

On the theoretical level this research has started from basic principles derived from the Theory of Planned Behaviour (т Р в) that looks at intentions to behave,' and not necessarily actual actions of individuals. It argues that attitudes, subjective norms and perceived behavioural control affect intentions to act and these in turn predict behaviour. т Р в starts from the premise that individuals make logical, reasoned decisions to engage in specific behaviour by evaluating the information available to them. The performance of a behaviour is determined by the individual's intention to engage in it (influenced by the value the individual places on the behaviour, the ease with which it can be performed and the views of significant others) and the perception that the behaviour is within his/her control (Ajzen, 1985). The theory was intended to explain all behaviour over which people have the ability to exert self-control. The key component to this model is behavioural intent; behavioural intentions are influenced by the attitude concerning the likelihood that the behaviour will have the expected outcome and the subjective evaluation of the risks and benefits of that outcome. Rosenberg's three-component structure was discussed when developing the research plan, in the sense that an attitude is a whole made up of cognitive (what an individual thinks of an object of attitude), emotional or affective (what an individual feels about an object of attitude) and conative or behavioural components (how an individual intends to behave towards an object of attitude) (Alessandri \& Vecchione, 2015). This model of attitude structure is also called the ABC model (affect, intention of behaviour, cognition) (Stern \& Oskamp, 1987).

The theoretical concept on which this research of beliefs and attitudes leans is the theory of the MODE model developed by Fazio (1993) and Myers and Twenge (2016). The model broadens the one-dimensional approach to attitudes by emphasizing the undisputable connection between beliefs, attitudes and intention of behaviours, with Myers and Twenge aware that 'the relationship of individual components of attitude is not simple and unambiguous' (Ajduković et al., 2005).

The MODE model ('motivation and opportunities as determinants') assumes that attitudes can influence intention of behaviour either through the conscious implications that they have on the intention of behaviour or by automatic selective processing for the posture of significant information. Specifically, a more precise MODE model is based on the assumption that attitudes, in addition to referring to certain objects, have their 'strength,' and that we can locate it on the so-called 'strength scale' accordingly, where zero is the complete indifference to the object of attitude. Only strong attitudes are stable and reliable in predicting behaviour. Attitudes also represent a link between the object of attitude itself and the individual's evaluation of the object. Attitudes are based on experience that in this case forms the basis of the evaluation. In the MODE model, the authors emphasize the importance of the so-called concept of activation of the aforementioned object connection and the existing evaluation, and link it to the scale of power where relative indifference is found at the lower part of the strength scale. In order for the attitude-behaviour process to be activated, there must be an external influence that can also represent a simple question posed about the object itself. At the opposite end of the scale where attitudes are strong, this activation can occur and automatically, without external stimuli, is already sufficient perception of the object to initiate the attitude-intention of the behaviour process.

Authors Sinatra et al. (2012) measured attitudes toward climate change caused by anthropological activity and found that respondents who had a more accepting attitude toward climate change were more likely to express a willingness to act. Authors Garay et al. (2018) explored cognitive mechanisms that motivate managers to introduce sustainability practices in their businesses. They concluded that managers' subjective norms explained more of their behavioural intentions than their attitudes or perceived behavioural controls.

The starting point for this paper was the assumption of a two-way relationship between climate change and tourism, and the importance of knowing the beliefs and attitudes of multiple stakeholders - managers in the entire tourist accommodation industry as key persons in tourism management and decisionmaking, and key actors in implementing environmen- 
tal protection, as well as implementing and developing business policies in the area of sustainable development (Bohdanowicz, 2005). The main objective of this paper was to analyse the influence of four different sociodemographic characteristics among managers concerning beliefs and attitudes on climate change: gender, level of education, length of service in the tourism sector and membership in ecological NGOS or activism in ecological actions and initiatives (Racz, 2019). The researchers' intention was to provide a series of insights that might be relevant for the development of sustainable practices in the tourism sector, and particularly the hotel industry in general, as they contribute to understanding the attitudes of key decision-makers. This can also provide the basis for predicting their intention of behaviour in relation to the application of environmental protection measures.

\section{Literature Review}

Climate change poses a unique challenge to the entire human civilization and affects all aspects of human life, including tourism. The Earth is currently $0.7^{\circ} \mathrm{C}$ warmer than in 1900 , and if all emissions are stopped today, the Earth will warm by a further 0.5$1^{\circ} \mathrm{C}$ in the next decade. Research shows that the biggest impact on these changes is the release of carbon dioxide into the atmosphere, which due to its properties enhances the greenhouse effect on Earth. Interest in climate change has increased in recent years, especially after the 2009 United Nations Climate Change Conference held in Copenhagen (Scott \& Becken, 2010; Gössling et al., 2012; Rosselló-Nadal, 2014; Rutty et al., 2017). Dogru et al. (2019) explore the extent to which vulnerability and resilience to climate change affect tourism and the overall economy. The results indicate that tourism is both more vulnerable and more resilient to climate change compared to the economy in general. Scott et al. (2019) argue that vulnerability is highest in many countries where tourism represents the largest percentage of GDP, as well as regions where tourism growth is expected to be the strongest over the coming decades.

Tourism depends on having a favourable climate, preserved environment and rich flora and fauna (Buckley, 2011; Müller \& Weber, 2008). To a degree, climate elements such as temperature, total hours of sunshine and rain periods define international tourism flows in Europe (Joop et al., 2015). Numerous key tourism factors are affected by climate change (Scott \& Lemieux, 2010; Kozak et al., 2008; Hamilton \& Tol, 2007).

Rising sea levels, changing ecosystems, changes in the water system on Earth, various health effects and more frequent extreme weather events will affect tourism not only in terms of reducing comfort, but also in terms of reduced safety (Michailidou et al., 2016). Tourism is extremely sensitive to climate change and it can endure many negative or positive effects (Joop et al., 2013; Wong et al., 2013; Schliephack \& Dickinson, 2017).

The tourism sector has seen significant growth in the last four decades (Gössling et al., 2013) and it is also a significant factor in the economic development of both developed and developing countries (Cannonier \& Burke, 2018; Dogru \& Bulut, 2018: Becken, 2019; Hall, 2019; Jentos et al., 2012; Saarinen \& Rogerson, 2014; Scheyvens \& Hughes, 2018). Some authors have focused on exploring the impact of climate change on tourism demand based on IPCC (Intergovernmental Panel on Climate Change) climate change projections (Hindley \& Font, 2017; Hall et al., 2016; Amelung et al., 2007; Scott \& Brenda, 2007). These projections encompass the global level, the country level, and destinations such as coastal areas and islands, as well as skiing destinations (Wyss \& Abegg, 2014; Dawson \& Scott, 2007).

There are not, however, many studies focused on the beliefs and attitudes of managers in tourism concerning the impact of climate change, especially when it comes to the interdependence between climate change and accommodation in tourism. Research focused on manager beliefs and attitudes regarding climate change and tourism, or research of a single aspect, is typically conducted for a particular country or destination. Trawoger (2014) analysed climate change perceptions of winter tourism stakeholders in Tyrol (Austria). He concluded that growing awareness of climate change is limited to perceiving the issue as a global phenomenon. Hall et al. (2016) presented a systematic overview of tourism accommodation providers and consumer attitudes, intention of behaviour and prac- 
tices pertaining to sustainable development, sustainability in general and climate change. Legrand et al. (2012) hypothesized that the hotel industry is responsible for $\mathrm{CO}_{2}$ emissions into the atmosphere and thus responsible for the intensifying climate change. They concluded that hotels have recognized how important sustainability and its principles have become and that green investments are on the rise. Yu-Ping, Hall \& Ozzane (2012) proposed that hotels and the hotel industry are the most vulnerable to climate change as a consequence of their primary resources. Their research results encompass attitudes, awareness and intention of behaviour of Taiwanese hotel managers with regard to climate change, its potential impact and their ecological practices in general. Authors Dube and Nhamo (2020) used a method approach; their study sought to document tourist perceptions and attitudes regarding the impact and future of the Victoria Falls World Heritage Site. Authors Torres-Bagur et al. (2019) conducted interviews with owners and managers to understand perceptions and identify the main problems associated with climate change in order to design effective mitigation and adaptation strategies to guarantee the sustainability of tourism and natural resources.

Tourism needs to introduce certain adjustment measures to boost the positive and mitigate the negative effects of future climate change (Perić \& Šverko Grdić, 2017). However, it must be emphasized that climate change will have a different effect on different destinations and, consequently, on the economic benefits of tourism.

\section{Mitigating Tourism-Induced Climate Change}

There are two primary strategic approaches when it comes to climate change - mitigation and adaptation. The two should not be observed separately, they are not an either/or choice. Instead, they are connected, alternative strategies that can achieve the best results through the use of well-developed instruments and measures for the simultaneous implementation of both. The goal of mitigation is to slow down climate change, while adaptation involves lowering climate change vulnerability (Jopp et al., 2015).

Another aim of the mitigation strategy is to reduce harmful emissions into the atmosphere, thus reducing the greenhouse effect. Mitigation strategies in general include enhancing, restoring, creating, or preserving current standards in order to offset unavoidable effects (Dogru et al., 2019). Climate resilience and the need for decarbonization are highlighted in communication in the tourism sector, but there is little evidence of significant action being taken regarding mitigation (Gössling \& Scott, 2018). All economic sectors will be required to contribute to reducing emissions in order to achieve the objective set by the Paris Climate Agreement - to limit global warming to $2^{\circ} \mathrm{C}$ above pre-industrial levels. Any increase in emissions from specific sectors or countries will mean that there is a widening gap between trajectories and mitigation objectives. For tourism, in a business-as-usual scenario, this would correspond to more than $2.5 \mathrm{Gt}$ of $\mathrm{CO}_{2}$ per year by 2050 (European Travel Commission, 2018).

Adaptation and mitigation are very important strategies for responding to climate change and they are equally important (Hambira \& Saarinen, 2015). Without early and timely mitigation, the costs of adaptation will rise, and the ability of countries and individuals to adapt effectively will be constrained. Understanding the nature and consequences of climate change is the basis of any serious mitigation or adaptation policies (Galeotti \& Roson, 2012). In order to be able to implement mitigation and adaptation, it is important to assess what the cost of inaction would be, i.e. the economic impact of climate change in a baseline scenario in which no policies are implemented. The greening of accommodation establishments (Hoogendoorn et al., 2015) and attempts at creating carbon-neutral tourism destinations could potentially be viable and address both adaptation and mitigation strategies.

\section{Methodology}

The study included managers from 1,084 individual tourist accommodation establishments from the territory of the entire Republic of Croatia, included in the list of categorized objects on the Ministry of Tourism's website on March 7, 2019. The survey included categorized hotels and apart-hotels, hotel and apartment complexes, categorized campsites, and marinas. It was conducted using online surveys and was completely anonymous, with targeted distribution of survey ques- 
tionnaires, i.e. calls through professional associations and competent bodies and chambers in the period from April to June 2019. To determine beliefs and attitudes about climate change and the impact of climate change and tourist accommodation, a questionnaire prepared for this research was used, which was based on the Euro Barometer Questionnaire 300 and 459 (European Commission, 2009, 2017). Furthermore, the questionnaire included a selection of modified questions used in previous research, but targeted with regard to the target population - top managers in tourist accommodation facilities in Croatia (Bohdanowicz, 2005, 2006; Leiserowitz et al., 2018). The final form of the survey questionnaire was obtained by including a series of original questions aimed precisely at the goals of this research and the target population, thus creating an original questionnaire.

Attitudes and beliefs were explored using the attitude measurement scale. The expressed degree of agreement with the proposed claims and the standardized manner of assessment determined the respondent's position. The first part of the questionnaire used a series of 30 statements related to global warming and climate change, and the relationship between tourism and climate change, according to which respondents had to express their degree of agreement with each statement on a 7-point Likert scale, with grade 1 meaning 'strongly disagree', 4 meaning 'neither agree nor disagree' and 7 meaning 'strongly agree' with the statement. The scale examined the cognitive, intention of behaviour and affective components of attitude. In the second part of the questionnaire, respondents were offered 6 terms related to the parent term 'climate change and global warming, in which they were asked to indicate the position best matching their feelings about climate change and global warming on a 7-point scale, which additionally examined the affective component of attitude. The action component of attitude was examined through a series of 8 statements, each related to individual personal involvement or intent to participate in any of the aforementioned adaptation measures or measures for reducing the negative impact of global warming through personal actions, expressed on a 7-point scale.

Post hoc comparisons of $p$-values were performed in each of the three component domains (cognitive, affective, and conative) for each of the observed sociodemographic characteristics. In order to analyse the share and contribution of each component of the attitude to the overall expressed level of environmental awareness, some total factor scores (given the different number of questions involved) were converted to a scale from o (least agreement/no agreement with each factor) to 100 (complete agreement with a factor) according to the formula in which the numerator is formed by the difference of the scores of the ladder of each factor, reduced by the smallest possible amount of the ladder of the factor, the denominator represents the possible range of the ladder of factors, and the result is multiplied by one hundred. Orientation to the right (higher score) denotes ecologically friendly intention of behaviour or understanding of the pattern, consequences, and correlation of phenomena with global warming and climate change.

IB M SPss Statistics software version 25.0 was used in the analysis. Data processing was performed using Microsoft Excel. In the entire survey the KolmogorovSmirnov test was used to analyse the distribution of continuous numerical values, and corresponding nonparametric tests were applied according to the obtained data. Categorical and nominal values were presented using corresponding frequencies and shares. Continuous values were presented using medians and interquartile ranges, and the differences between them were analysed by the Kruskal-Wallis test, and presented in a box and whisker plot showing median values, interquartile ranges, minimum and maximum values, and extreme values which differ from the medians by more than 1.5 interquartile ranges.

\section{Results and Findings}

From the total of 1,084 categorized tourist accommodation establishments, the survey collected a total of 283 fully completed questionnaires, which represents a response rate of $26.1 \%$. The study included 283 participants of different genders, of which 168 (59.36\%) were male and 115 (40.64\%) were female. Analysing the highest achieved level of education has shown that among the 283 participants there were 77 participants $(27.20 \%)$ with secondary school education, 66 partici- 
Table 1 Descriptive Statistics: Numerical Data for Cognitive Component

\begin{tabular}{|c|c|c|c|c|c|c|c|c|c|c|}
\hline Category & Item & $N$ & sv & SD & Min & Max & Perc. 25 & Median & Perc. 75 & $P$ \\
\hline \multirow[t]{2}{*}{ Gender } & Male & 168 & 60.31 & 19.15 & 19.70 & 90.91 & 42.42 & 65.15 & 76.89 & $<0.001$ \\
\hline & Female & 115 & 73.70 & 12.76 & 32.58 & 95.45 & 67.42 & 76.52 & 81.82 & \\
\hline \multirow[t]{4}{*}{ Educational level } & Secondary & 77 & 47.58 & 14.58 & 22.73 & 81.82 & 35.61 & 46.21 & 57.58 & $<0.001$ \\
\hline & High & 66 & 63.28 & 16.73 & 25.76 & 91.67 & 52.27 & 67.42 & 74.24 & \\
\hline & University & 124 & 77.06 & 8.85 & 43.94 & 95.45 & 73.11 & 79.92 & 82.20 & \\
\hline & Postgraduate & 16 & 75.71 & 17.84 & 19.70 & 90.15 & 66.67 & 79.55 & 88.64 & \\
\hline \multirow[t]{2}{*}{ NGO membership } & No & 244 & $63 \cdot 30$ & 18.13 & 19.70 & 91.67 & 50.38 & 68.18 & 77.65 & $<0.001$ \\
\hline & Yes & 39 & 81.06 & 6.36 & 65.91 & 95.45 & 76.52 & 81.06 & 85.61 & \\
\hline \multirow{3}{*}{$\begin{array}{l}\text { Working experience } \\
\text { in tourism }\end{array}$} & $<5$ years & 65 & 49.57 & 16.29 & 26.52 & 90.15 & 34.85 & 46.97 & 61.36 & $<0.001$ \\
\hline & 5-15 years & 133 & 68.83 & 17.45 & 22.73 & 91.67 & 58.33 & 74.24 & 81.06 & \\
\hline & $>15$ years & 85 & $73 \cdot 31$ & 11.80 & 19.70 & 95.45 & 65.91 & 75.00 & 81.06 & \\
\hline
\end{tabular}

Table 2 Descriptive Statistics: Numerical Data for Affective Component

\begin{tabular}{|c|c|c|c|c|c|c|c|c|c|c|}
\hline Category & Item & $N$ & sv & SD & Min & Max & Perc. 25 & Median & Perc. 75 & $P$ \\
\hline \multirow[t]{2}{*}{ Gender } & Male & 168 & 48.58 & 21.59 & 8.33 & 86.11 & 27.78 & 52.78 & 66.67 & $<0.001$ \\
\hline & Female & 115 & 61.11 & 15.19 & 13.89 & 83.33 & 55.56 & 63.89 & 72.22 & \\
\hline \multirow[t]{4}{*}{ Educational level } & Secondary & 77 & $34 \cdot 38$ & 18.15 & 8.33 & 86.11 & 19.44 & 27.78 & 50.00 & $<0.001$ \\
\hline & High & 66 & 51.89 & 18.89 & 13.89 & 86.11 & 38.89 & 58.33 & 66.67 & \\
\hline & University & 124 & 66.15 & 11.62 & 27.78 & 83.33 & 61.11 & 69.44 & 75.00 & \\
\hline & Postgraduate & 16 & 57.12 & 10.49 & 30.56 & 66.67 & 55.56 & 61.11 & 62.50 & \\
\hline \multirow[t]{2}{*}{ NGO membership } & No & 244 & 50.94 & 20.16 & 8.33 & 86.11 & 31.94 & 55.56 & 66.67 & $<0.001$ \\
\hline & Yes & 39 & 70.73 & 8.76 & 38.89 & 86.11 & 66.67 & 72.22 & 75.00 & \\
\hline \multirow{3}{*}{$\begin{array}{l}\text { Working experience } \\
\text { in tourism }\end{array}$} & $<5$ years & 65 & 37.39 & 20.66 & 8.33 & 83.33 & 19.44 & 30.56 & 55.56 & $<0.001$ \\
\hline & $5-15$ years & 133 & 56.43 & 18.96 & 13.89 & $83 \cdot 33$ & 44.44 & 61.11 & 69.44 & \\
\hline & $>15$ years & 85 & 61.80 & 13.91 & 27.78 & 86.11 & 52.78 & 66.67 & 72.22 & \\
\hline
\end{tabular}

pants (23.32\%) with higher education, 124 participants (43.81\%) with a university degree and 16 (5.67\%) with postgraduate education. Regarding the length of employment or, to put it another way, the length of working experience in tourism, 65 (22.97\%) of respondents have been working in tourism for less than 5 years, 133 (46.99\%) have been working for 5-15 years, and 85 (30.04\%) for more than 15 years.

For the visual presentation of obtained data a boxplot was used as a standardized way of displaying the dataset based on a five-number summary: the minimum, the maximum, the sample median, and the first and third quartiles. A boxplot, is a method for graphically depicting groups of numerical data through their quartiles. For further analysis we added Tables 1-3 that numerically show the elements of descriptive statistics for each individual component of the attitude on the basis of which the graphs were made.

\section{Cognitive Component}

The study found statistically significant differences in the cognitive component of attitude with respect to the gender of managers, with female managers showing statistically significant greater acceptance of the pro- 
Table 3 Descriptive Statistics: Numerical Data for Conative Component

\begin{tabular}{|c|c|c|c|c|c|c|c|c|c|c|}
\hline Category & Item & $N$ & sv & SD & Min & Max & Perc. 25 & Median & Perc. 75 & $P$ \\
\hline \multirow[t]{2}{*}{ Gender } & Male & 168 & 69.95 & 19.47 & 33.33 & 100.00 & 52.08 & 77.08 & 85.42 & $<0.001$ \\
\hline & Female & 115 & 78.79 & $15 \cdot 34$ & $33 \cdot 33$ & 100.00 & 68.75 & 81.25 & 89.58 & \\
\hline \multirow[t]{4}{*}{ Educational level } & Secondary & 77 & 57.87 & 16.20 & $33 \cdot 33$ & 100.00 & 45.83 & 54.17 & 66.67 & $<0.001$ \\
\hline & High & 66 & 71.31 & 16.90 & 35.42 & 93.75 & 62.50 & 77.08 & 83.33 & \\
\hline & University & 124 & 84.26 & 12.90 & $33 \cdot 33$ & 100.00 & 80.21 & 85.42 & 92.71 & \\
\hline & Postgraduate & 16 & 75.13 & 14.04 & 50.00 & 95.83 & 68.75 & 68.75 & 88.54 & \\
\hline \multirow[t]{2}{*}{ NGO membership } & No & 244 & 70.77 & 18.02 & $33 \cdot 33$ & 100.00 & 54.17 & 75.00 & 85.42 & $<0.001$ \\
\hline & Yes & 39 & 90.92 & 8.69 & 70.83 & 100.00 & 85.42 & 91.67 & 100.00 & \\
\hline \multirow{3}{*}{$\begin{array}{l}\text { Working experience } \\
\text { in tourism }\end{array}$} & $<5$ years & 65 & 57.85 & 17.41 & $33 \cdot 33$ & 95.83 & 43.75 & 52.08 & 70.83 & $<0.001$ \\
\hline & 5-15 years & 133 & 74.11 & 16.73 & 33.33 & 100.00 & 60.42 & 77.08 & 85.42 & \\
\hline & $>15$ years & 85 & 84.66 & 12.22 & 37.50 & 100.00 & 79.17 & 87.50 & 93.75 & \\
\hline
\end{tabular}

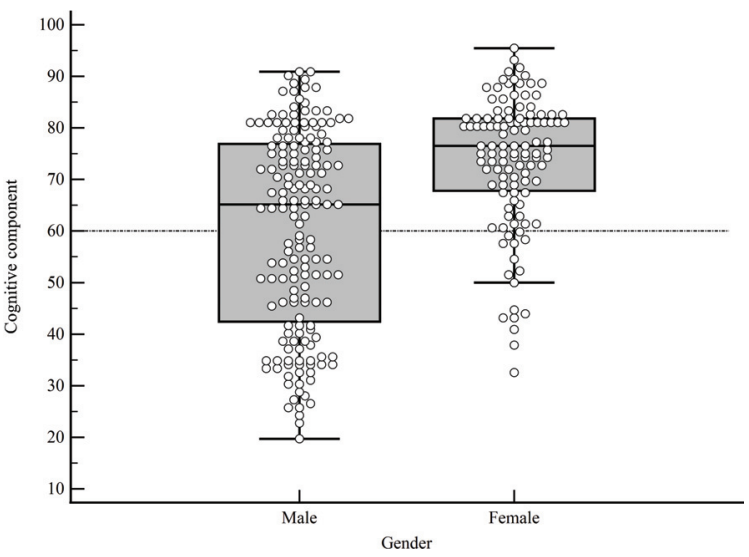

Figure 1 Differences in Respondents' Attitudes Shown in a Box and Whisker Plot with Respect to Respondents' Gender for the Cognitive Component of Attitude

ecological claims offered compared to male managers, or higher levels of environmental awareness (see Figure 1).

The post hoc comparisons showed that there is a statistically significant difference in the attitudes of managers depending on the level of education completed, and in each of the comparisons made between the compared 4 groups, except when comparing the attitudes of managers with a high school diploma compared to those of postgraduate students. From the data presented in Figure 2, it can be concluded that the

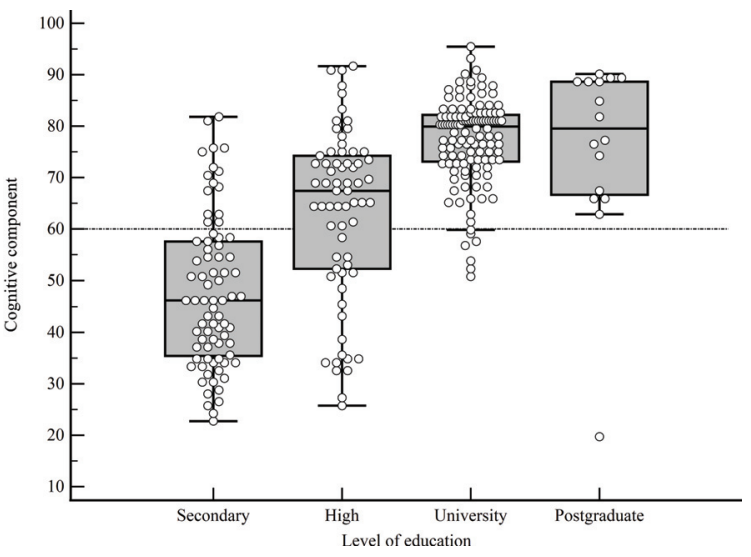

Figure 2 Differences in Respondents' Attitudes Shown in a Box and Whisker Plot with Respect to Respondents' Level of Education for the Cognitive Component of Attitude

highest degree of acceptance of the claims, and thus the highest level of environmental knowledge, was shown by the managers with the highest level of education. The lowest scores were recorded in the group of respondents whose highest level is secondary education, which confirmed the importance of the completed level of previous education in the formation of the cognitive component of attitudes (see Figure 2).

Membership of respondents in non-governmental (NGo) environmental associations was expected to prove to be a statistically significant differentiating 


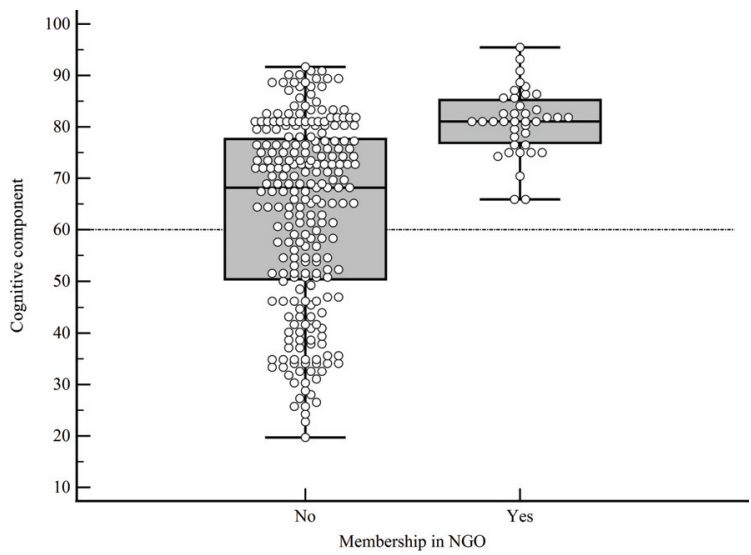

Figure 3 Differences in Respondents' Attitudes Shown in a Box and Whisker Plot with Respect to Respondents' Membership in NGO for the Cognitive Component of Attitude

factor for the cognitive component of managerial attitude. Managers involved in the work of environmental NGOS are expected to express significantly more proecologically affirmative attitudes than socially nonengaged respondents, relative to those who are not active members of the NGO scene (see Figure 3 ).

Work experience has emerged through post hoc comparisons as a factor leading to a statistically significant difference in attitudes when comparing three groups of respondents: those with less than five years of work experience compared with those with 5-15 years of experience or compared with those respondents with over 15 years of experience. Differences were also confirmed when comparing the attitudes of respondents with 5-15 years of experience compared to those of respondents with more than 15 years of experience. The data shows that the group of managers with the most seniority shows, in the cognitive attitude component, the highest degree of acceptance or agreement with the statements offered, compared to the other two groups of respondents, related to the most developed level of environmental awareness (see Figure 4).

\section{Affective Component}

The study found statistically significant differences in the affective, emotional component of attitude with respect to manager gender. Female managers showed a

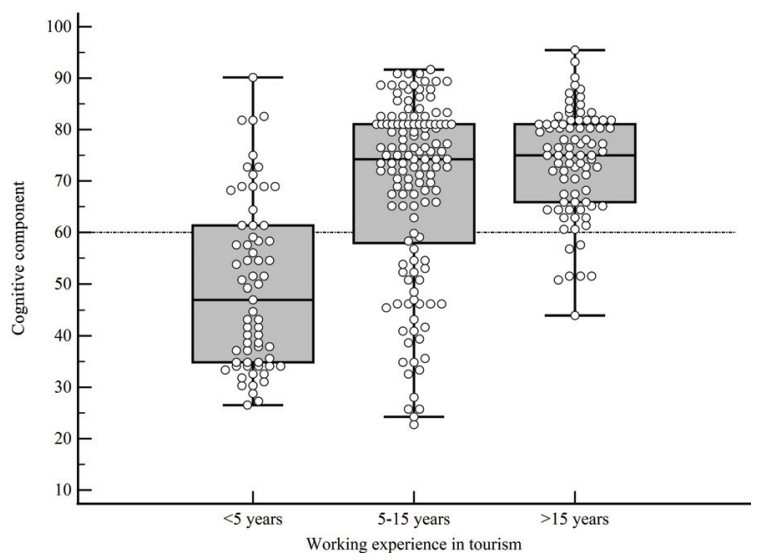

Figure 4 Differences in Respondents' Attitudes Shown in a Box and Whisker Plot with Respect to Respondents' Years of Work Experience in Tourism for the Cognitive Component of Attitude

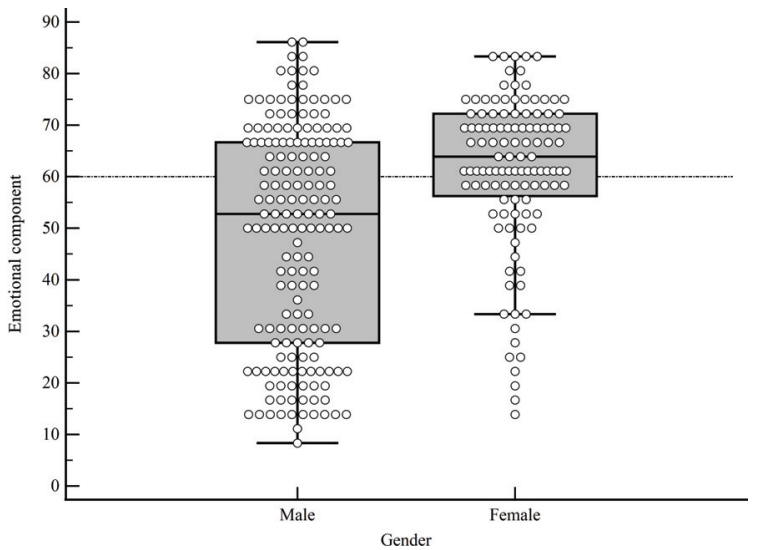

Figure 5 Differences in Respondents' Attitudes Shown in a Box and Whisker Plot with Respect to Respondents' Gender for the Emotional Component of Attitude

statistically significant greater acceptance of the proenvironmental assertions offered than male managers (see Figure 5).

The conducted post hoc comparisons showed that there is a statistically significant difference in the attitudes of managers depending on the level of their highest completed education, and in each of the comparisons conducted between each of the 4 groups.

From the data presented in Figure 6, it can be concluded that the highest degree of acceptance of the 


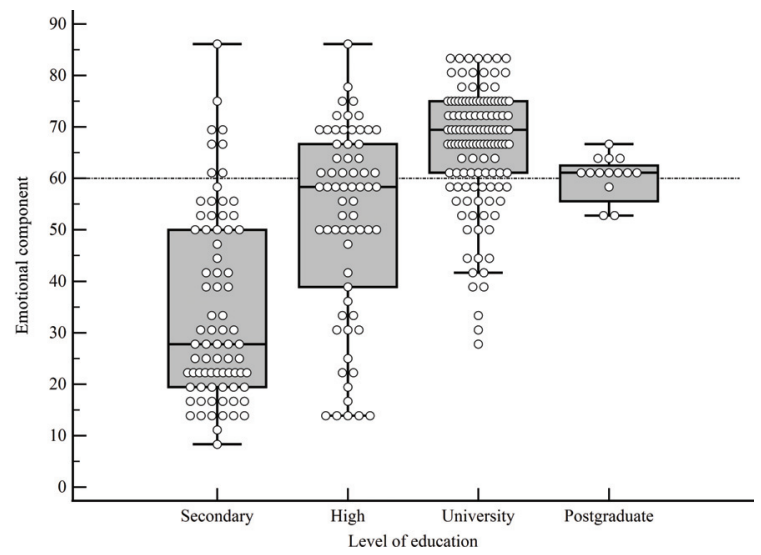

Figure 6 Differences in Respondents' Attitudes Shown in a Box and Whisker plot with Respect to Respondents' Level of Education for the Emotional Component of Attitude

claims, and thus the highest degree of environmental sensitivity in the affective, emotional component, was shown by the managers with the highest completed education, while the lowest results were recorded in the group of respondents with the lowest, i.e. secondary education, thus confirming the importance of the completed level of previous education in the attitude formation process (see Figure 6).

Respondents' membership in NGOs, as expected, proved to be a statistically significant differentiating factor for the affective component of managerial attitude. Managers involved in the work of environmental NGOs are expected to have significantly more proecologically affirmative views than respondents not engaged in the work of environmental NG Os (see Figure 7).

Work experience has emerged through post hoc comparisons as a factor that leads to a statistically significant difference in managerial attitudes when comparing the attitudes of managers classified into three groups: managers with less than five years of service, managers with 5-15 years of service, and those with over 15 years of service.

Differences were also confirmed when comparing the attitudes of respondents with 5-15 years of experience with those of over 15 years of experience. The data shows that the group of managers with the most years of experience shows, in the affective, emotional com-

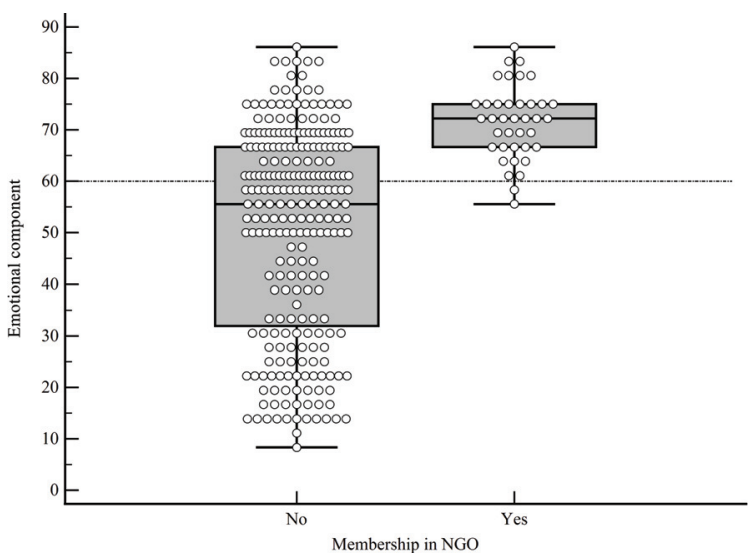

Figure 7 Differences in Respondents' Attitudes Shown in a Box and Whisker Plot with Respect to Respondents' Membership in NGO for the Emotional Component of Attitude

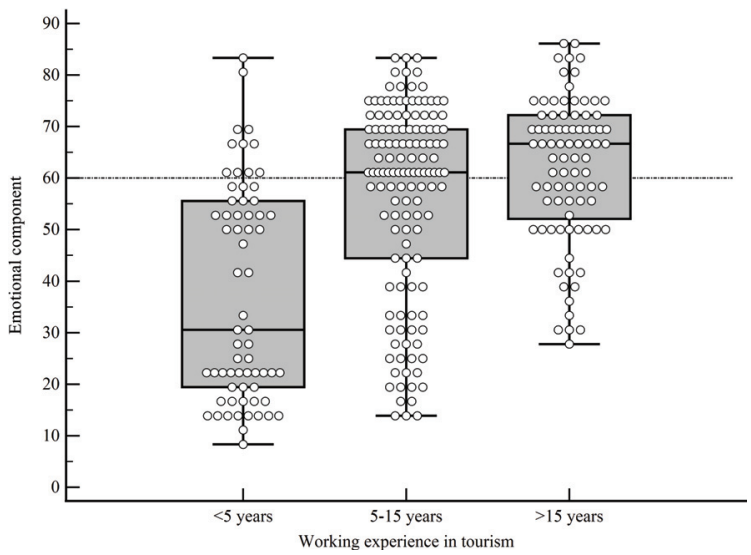

Figure 8 Differences in Respondents' Attitudes Shown in a Box and Whisker Plot with Respect to Respondents' Years of Work Experience in Tourism for the Emotional Component of Attitude

ponent, the highest degree of acceptance or agreement with the statements offered compared to the other two groups of respondents (see Figure 8).

\section{Behavioural, Conative Component}

The study found statistically significant differences in attitudes for the conative, behavioural component of attitude with respect to the gender of managers, graphically presented in Figure 9.

It can be concluded that female managers showed 


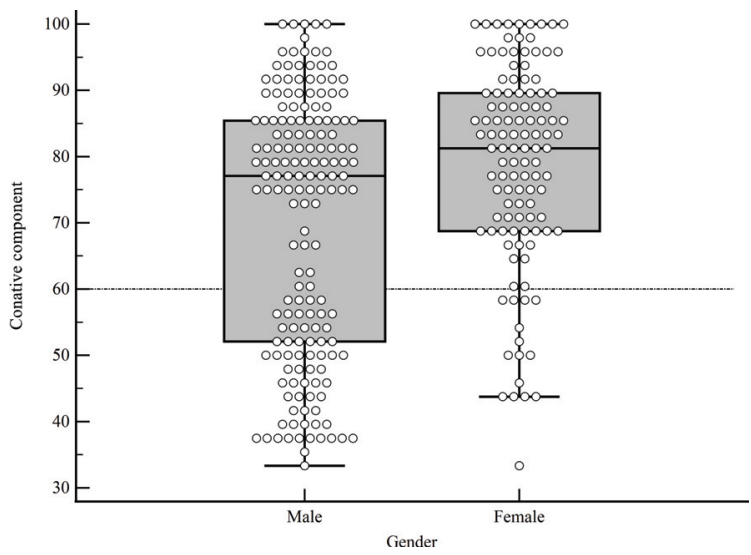

Figure 9 Differences in Respondents' Attitudes Shown in a Box and Whisker Plot with Respect to Respondents' Gender for the Conative Component of Attitude

a statistically significant greater acceptance of the proecological claims offered compared to male managers. This points to the conclusion that women managers are more sensitive to participating in environmental actions and implementing environmental strategies and plans (see Figure 9).

The post hoc comparisons showed that there is a statistically significant difference in attitudes of managers depending on the level of education completed, and in each of the comparisons between the 4 groups, except when comparing the attitudes of managers with completed university education with those with postgraduate education.

From the data presented in Figure 10, it can be concluded that the highest degree of acceptance of the claims, and thus the highest degree of environmental sensitivity in the intention of behaviour component was shown by the managers with the highest qualifications, while the lowest results were recorded in the group with the lowest, i.e. secondary education. In this way, the importance of the completed level of previous education in forming the intention of behaviour component of attitudes was confirmed (see Figure 10).

Respondents' membership in NGOs proved to be a statistically significant differentiating factor for the conative, intention of behaviour component of the managers' attitudes. Managers involved in the work of NGOS are significantly more pro-ecologically active

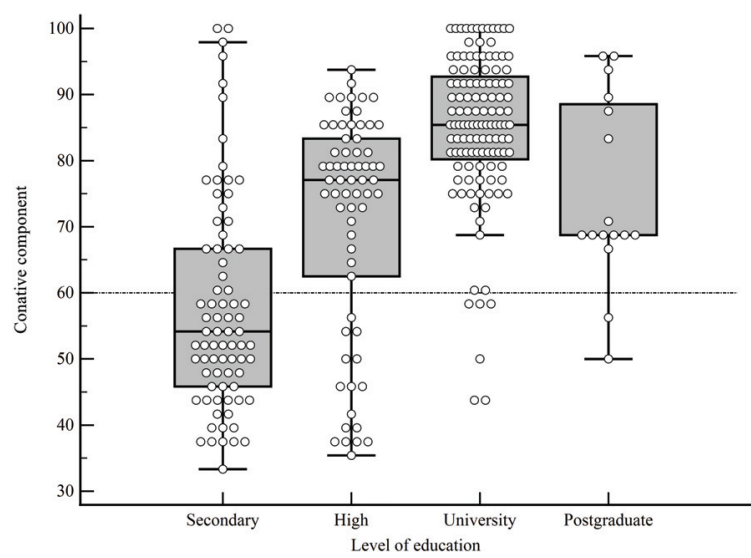

Figure 10 Differences in Respondents' Attitudes Shown in a Box and Whisker Plot with Respect to Respondents' Level of Education for the Conative Component of Attitude

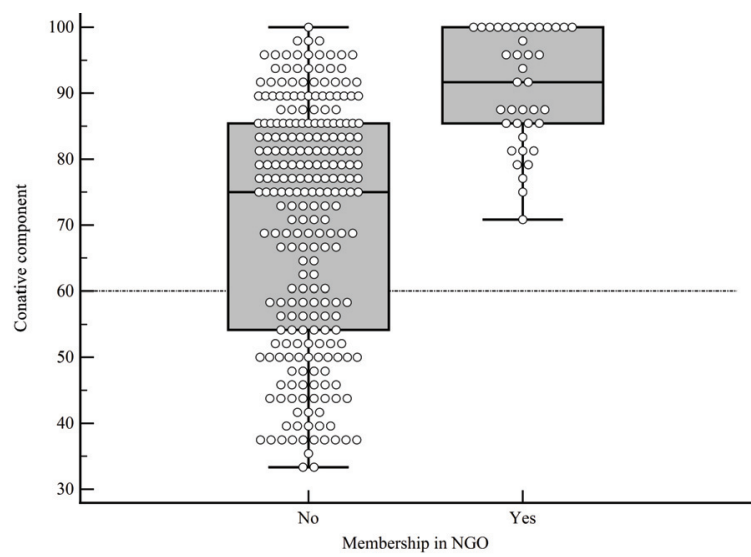

Figure 11 Differences in Respondents' Attitudes Shown in a Box and Whisker Plot with Respect to Respondents' Membership in NGO for the Conative Component of Attitude

in practice, and thus exhibit significantly more proecologically affirmative attitudes than non-engaged respondents.

The results presented in Figure 11 could perhaps be explained by the assumption that there is positive feedback between respondents' engagement in environmental actions organized by NGOS and their proenvironmental intention of behaviour in the tourism business entity in which they hold a managerial position (see Figure 11). 


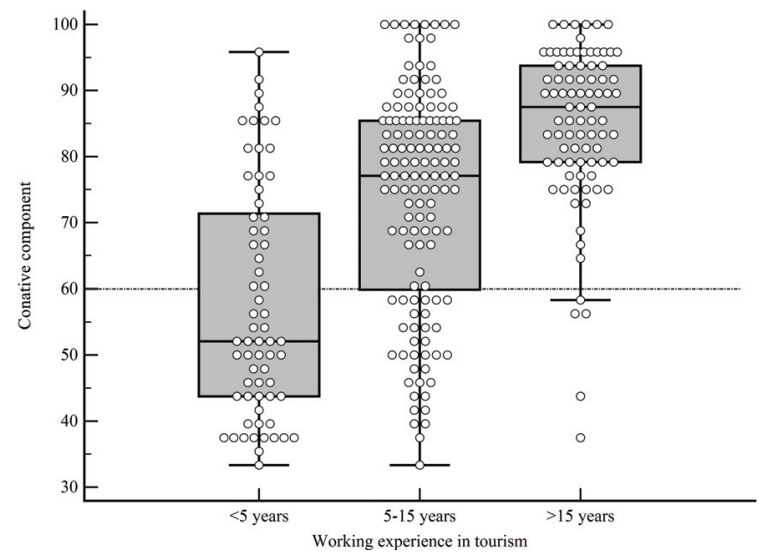

Figure 12 Differences in Respondents' Attitudes Shown in a Box and Whisker Plot with Respect to Respondents' Years of Work Experience in Tourism for the Conative Component of Attitude

Work experience has been shown through post hoc comparisons as a factor that leads to a statistically significant difference in attitudes when comparing three groups of respondents depending on length of service, or when comparing attitudes of those with less than five years of service compared to those with 5-15 years or with views of those with over 15 years of service.

Differences were also confirmed when comparing the attitudes of respondents with 5-15 years of experience compared with those with more than 15 years. The data presented in Figure 12 shows that the group of managers with the most years of experience also shows in the intention of behaviour component the highest degree of acceptance or agreement with the offered statements. This, in practice, means that the highest pro-ecological intention of behaviour can be expected from this group in comparison with the other two groups of respondents (see Figure 12).

\section{Discussion}

Taking into account all other environmental problems, climate change has become the biggest challenge and threat to the survival of the human civilization, with far reaching consequences and a wide influence on and relationship with virtually every aspect of human life. The 2014 International Panel on Climate Change stated that it is confirmed with near certainty that human activities are the dominant cause of global warming, leading to multiple manifestations of climate change' (IPCC, 2014). This paper is focused on the beliefs and attitudes of tourism managers on the interplay between climate change and tourism, because the selection of a sustainable tourism development strategy, and particularly its implementation, is closely linked to the beliefs and attitudes of key decision makers. That is, the views, beliefs and attitudes of top managers, the decision makers, is what the success of the implementation of the selected strategies depends on (Schliephack \& Dickinson, 2017). Attitudes and beliefs are formed in the processes of socializing and are acquired directly, based on experience with the object of the attitude, or indirectly, through interaction with the social environment. At the same time, attitudes, as an acquired tendency to react either positively or negatively to external persons, objects or situations, or to one's own qualities, ideas, or actions, are connected to certain sociodemographic characteristics. This has once again been confirmed by our results. Managers' attitudes and beliefs are essential in planning how to minimize or mitigate the negative impacts of climate change on the tourist accommodation industry, because several authors suggest that unfortunately, no prevention of negative tourism impact is possible, but it is possible to manage impact better and/or to harmonize it with the positive. It is always a matter of optimizing the impact of the tourism, which is realized through the effective management of the impact (planning and developmental process) (Gursoy et al., 2019).

At the same time, their attitudes are important for implementing measures aimed at minimizing the impact of how tourism contributes to global warming through greenhouse gas emissions, especially hotel accommodation and lodging, as well as transportation (Gössling et al., 2012).

If we desire to make significant changes to ensure sustainable development, understanding managers' attitudes and beliefs is important in order to understand the risks and opportunities for changing the 'business as usual' practice which has become unsustainable (Becken \& Hay, 2007). Considering the sociodemographic characteristics of the respondents 
and their correlation with the views expressed, previous studies, e.g. the results of the Eurobarometer survey, have also shown that more educated respondents feel well-informed about climate change (its causes, consequences and ways of fighting it), or more actively perceive the phenomenon of climate change as a very serious problem. They believe that the process may be halted, that alternative fuel can be used to combat it, and that climate change will have a more positive impact on the European economy. This is in contrast to respondents who spent a shorter time in education who do not think climate change is a serious problem (European Commission, 2009).

The importance of higher levels of completed education for developing environmental awareness and connecting the cognitive with the conative component has been previously shown by other researchers (Bradley et al., 1999). They found that increasing environmental knowledge in some individuals results in more positive attitudes and environmentally responsible intention of behaviour towards the environment (McMillan et al., 2004). The results of this study are in agreement with the results of a study conducted on the general population in Croatia, which showed that the level of education is a significant independent factor, as the results indicate that the lower the level of education, the lower the level of environmental concern (Landau et al., 2009).

Since both consumers and service providers need to develop pro-environmental attitudes and pro-environmental intentions of behaviour, the role of informed tourism managers as leaders of change is very important for the further development of tourism. Empirical research should identify, isolate, and create holders of positive change. The first step is learning about their attitudes and beliefs, as well as connecting the cognitive, affective, and conative intention of behaviour components, to which this research has contributed. The most important limitations of the survey are a relatively poor response rate of managers to the call for participation in the survey, and a possible selection bias, as it could be assumed that more managers who have more pro-environmental attitudes participated in the study because they value environmental issues more.

\section{Conclusion}

Managers' attitudes and beliefs are important in order to anticipate, plan and direct the use of mitigation measures and to manage the negative impacts of climate change and the tourist accommodation industry. This research showed that there are very few managers who are either personally engaged in an environmental NGO or accept environmental activism as their commitment, despite the strong link between tourism, industry and ecology. The membership of respondents in an environmental association or self-determined engagement in environmental activism was analysed and 39 (13.78\%) active members of different NGOS were observed among the respondents, compared to $244(86.22 \%)$ who did not report membership or activist engagement in any NGO or initiative. When comparing the three components that are constituents of attitudes in accordance with the theory of the threefold structure of attitudes, the managers have shown that the most powerful and positively-oriented was the intention of behaviour component, followed by the cognitive and finally the equally positively oriented conative component. It has also been confirmed that the beliefs and attitudes of managers in tourist accommodation differ based on their various sociodemographic characteristics. The results have confirmed that managers in tourist accommodation facilities have established beliefs and attitudes about the interinfluence of climate change and tourist accommodation. After scoring the stated degree of acceptance of individual claims according to the seven-point Likert scale, it showed the specific influence of various sociodemographic characteristics on all three components of attitude. The presented results have shown stronger pro-ecological attitudes and higher levels of ecological awareness concerning climate change among managers who are of the female gender, who have completed tertiary education, who have more years of work experience and who consider themselves as environmental activists. The results of this paper provide insight that may be relevant for the development of sustainable practices in the tourism sector and particularly in the hotel industry, as they contribute to understanding the attitudes of key decision makers and can provide the basis for predicting 
their intention of behaviour in relation to implementing environmental protection measures.

In future research, it is important to start from the limitations of this research in two directions: it is necessary to conduct a new study on a representative sample of managers and achieve full turnout in order to avoid the selection bias present in this research. In particular, an attempt should be made to compare the stated intentions of behaviour with the field research regarding the measures actually implemented in the accommodation facilities themselves.

\section{References}

Ajduković, M., Sladović Franz, B., \& Kamenov, Ž. (2005). Stavovi stručnjaka socijalne skrbi prema izdvajanju djece iz obitelji i udomiteljstvu. Ljetopis socijalnog rada, 12(1), $39-66$.

Ajzen, I. (1985). From intentions to actions: A theory of planned behavior. V J. Kuhl in J. Beckmann (Eds.), Action control (pp. 11-39). Springer.

Alessandri, G., \& Vecchione, M. (2015). On the factor structure of the Rosenberg (1965) General Self Esteem Scale. American Psychological Association, 27(2), 621-635.

Amelung, B., Nicholls, S., \& Viner, D. (2007). Implications of global climate change for tourism flows and seasonality. Journal of Travel Research, 45(3), 285-296.

Ančić, B., Puđak, J., \& Domazet, M. (2016). Vidimo li klimatske promjene u Hrvatskoj? Istraživanje stavova o nekim od aspekata klimatskih promjena u hrvatskom društvu. Hrvatski meteorološki časopis, 51, 27-45.

Becken, S. (2019). Decarbonising tourism: Mission impossible? Tourism Recreation Research, 44(4), 419-433.

Becken, S., \& Hay, J. E. (2007). Tourism and climate change: Risks and opportunities. Channel View Publications.

Becken, S., Whittlesea, E., Loehr, J., \& Scott, D. (2020). Tourism and climate change: Evaluating the extent of policy integration. Journal of Sustainable Tourism, 28(10), 1-22.

Bohdanowicz, P. (2005). European hoteliers' environmental attitudes: Greening the business. Cornell Hotel and Restaurant Administration Quarterly, 46(2), 188-204.

Bohdanowicz, P. (2006). Environmental awareness and initiatives in the Swedish and Polish hotel industries: Survey results. International Journal of Hospitality Management, 25(4), 662-682.

Bradley, J., Campbell, T., Waliczek, M., \& Zajicek, J. M. (1999). Relationship between environmental knowledge and environmental attitude of high school students. The Journal of Environmental Education, 30(3), 17-21.
Buckley, R. (2011). Tourism and environment. Annual Review of Environmental and Resources, 36, 397-416.

Cannonier, C., \& Burke, M. G. (2018). The economic growth impact of tourism in small island developing states: Evidence from the Caribbean. Tourism Economics, 25(1), 85108.

Dawson, J., \& Scott, D. (2007). Climate change vulnerability of the Vermont ski torism industry (USA). Annals of Leisure Research, 10(3-4), 550-572.

Dogru, T., \& Bulut, U. (2018). Is tourism an engine for economic recovery? Theory and empirical evidence. Tourism Management, 67, 425-434.

Dogru, T., Marchio E. A., Bulut, U., \& Suess, C. (2019). Climate change: Vulnerability and resilience of tourism and the entire economy. Tourism Management, 72, 292-305.

Dube, K., \& Nhamo, G. (2020). Tourist perceptions and attitudes regarding the impacts of climate change on Victoria Falls. Bulletin of Geography, Socio-Economic Series, $47(47), 27-44$.

European Travel Commission. (2018). Tourism and climate change mitigation: Embracing the Paris agreement - pathways to decarbonisation. Brussels.

European Commission. (2009). Europeans' attitudes towards climate change: Report (Special Eurobarometer 300).

European Commission. (2017). Climate change: Report (Special Eurobarometer 459).

Fazio, H. F. (1993). Variability in the likelihood of automatic attitude activation: Data reanalysis and commentary on Bargh, Chaiken, Govender, and Pratto. Journal of Personality and Social Psychology, 64(5), 753-758.

Galeotti, M., \& Roson, R. (2012). Economic impacts of climate change in Italy and the Mediterranean: Updating the evidence. Journal of Sustainable Development, 5(5), 27-41.

Garay, L., Font, X., \& Corrons, A. (2018). Sustainability Oriented innovation in tourism: An analysis based on the decomposed theory of planned behaviour. Journal of Travel Research, 58(4), 622-636.

Gössling, S., \& Scott, D. (2018). The decarbonisation impasse: Global tourism leaders' views on climate change mitigation. Journal of Sustainable Tourism, 26(2), 1-16.

Gössling, S., Scott, D., \& Hall, M. (2013). Challenges of tourism in a low carbon economy. WIRES Climate Change, 4(6), 525-538.

Gössling, S., Scott, D., Hall, C. M., Ceron, J. P., \& Dubois, G. (2012). Consumer behaviour and demand response of tourists to climate change. Annals of Tourism Research, 39(1), 36-58.

Gursoy, D., Ouyang, Z., Nunkoo, R., \& Wei, W. (2019). 
Residents' impact perceptions of and attitudes towards tourism development: A meta-analysis. Journal of Hospitality Marketing \& Management, 28(3), 306-333.

Hall, C. M. (2019). Constructing sustainable tourism development: The 2030 Agenda and the managerial ecology of sustainable tourism. Journal of Sustainable Tourism, 27(7), 1044-1060.

Hall, C. M., Daval, N., Majstorović, D., Mills, H., PaulAndrews, L., Wallace, C., \& Truong, V. D. (2016). Accommodation consumers and providers attitudes, behaviours and practices for sustainability: A systematic review. Sustainability, 8(625), 1-30.

Hambira, W. L., \& Saarinen, J. (2015). Policy-makers' perceptions of the tourism-climate change nexus: Policy needs and constraints in Botswana. Development Southern Africa, 32(3), 350-362.

Hamilton, J. M., \& Tol, R. S. J. (2007). The impact of climate change on tourism in Germany, the UK and Ireland: A simulation study. Regional Environmental Change, 7(3), 161-172.

Hindley, A., \& Font, X. (2017). Etics and influence sin tourist perceptions of climate change. Current Issues in Tourism, 2o(16), 1-17.

Hoogendoorn, G., Grant, B., \& Fitchett, J. (2015). Towards green guest houses in South Africa: The case of Gauteng and KwaZulu-Natal. South African Geographical Journal, 97(2), 123-138.

IP CC. (2014). Climate change 2014: Synthesis report; Contribution of Working Groups I, II and III to the Fifth Assessment Report of the Intergovernmental Panel on Climate Change. https://www.ipcc.ch/site/assets/uploads/ 2018/o2/SYR_AR5_FINAL_full.pdf

Jentos, A. C., Malone, E., Mastrangelo, E., Hardee, K., \& Bremond, A. (2012). Linking climate change and development goals: Framing, integrating and measuring. Climate and Development, 4(2), 141-156.

Joop, R., De Lacy, T., Mair, J., \& Fluker, M. (2013). Using a regional tourism adaptation framework to determine climate change adaptation option for Victoria's surf coast. Asia Pacific Journal of Tourism Research, 18(1-2), 144164.

Jopp, R., Mair, J., Delacy, T., \& Fluker, M. (2015). Climate change adaptation: Destination management and the green tourist. Tourism Planning \& Development, 12(3), 300-320.

Kocak, E., Ulucak, R., \& Şentürk Ulucak, Z. (2020). The impact of tourism developments on $\mathrm{CO}_{2}$ emissions. Tourism Management Perspectives, 33, 100611. https://doi .org/10.1016/j.tmp.2019.100611
Kozak, N., Uysal, M., \& Birkan, I. (2008). An analysis of cities based on tourism supply and climatic conditions in Turkey. Tourism Geographic, 10(1), 81-97.

Landau, S., Legro, S., \& Vlašić, S. (2009). A climate for change: Climate change and its impacts on society and economy in Croatia. UNDP Croatia.

Legrand, W., Kirsche, C., Sloan, P., \& Simons-Kaufmann, C. (2012). Making 202020 happen: Is the hospitality industry mitigating its environmental impacts? The barriers and motivators that German hoteliers have to invest in sustainable management strategies and technologies and their perceptions of online self help toolkits. WIT Transactions on Ecology and the Environment, 161, 115-126.

Leiserowitz, A., Edward, W., Maibach, E. W., \& Roser-Renouf, C. (2018) Climate change in the American mind: March 2018 Yale project on climate change communication. George Mason University Center for Climate Change Communication.

Mahadew, R., \& Appadoo, K. A. (2019). Tourism and climate change in Mauritius. Tourism Review, 74(2), 204-215.

McMillan, E. E., Wright, T., \& Beazley, K. (2004). Impact of a university-level environmental studies class on students' values. The Journal of Environmental Education, 35(3), 19-27.

Michailidou, A. V., Vlachokostas, C., \& Moussiopoulos, N. (2016). Interactions between climate change and the tourism sector: Multiple-criteria decision analysis to assess mitigation and adaptation options in tourism areas. Tourism Managemet, 55, 1-12.

Müller, H., \& Weber, F. (2008). Climate change and tourism - Scenario analysis for the Bernese Oberland in 2030. Tourism Review, 63(3), 57-71.

Myers, D., \& Twenge. J. (2016). Loose-leaf for social psychology (12th ed.). McGraw-Hill Education.

Perić, J., \& Šverko Grdić, Z. (2017). Klimatske promjene i turizam. University of Rijeka.

Racz, A. (2019). Climate changes as determinants in shaping tourism supply: Attitudes of management; Doctoral dissertation summary. Tourism and Hospitality Management, 25(2), 439-444.

Rosselló-Nadal, J. (2014). How to evaluate the effects of climate change on tourism. Tourism Management, 42(c), 334-340.

Rutty, M., Scott, D., Johnson, P., Pons, M., Steiger, R., \& Vilella, M. (2017). Using ski industry response to climatic variability to assess climate change risk: An analogue study in eastern Canada. Tourism Management, $58,196-204$.

Saarinen, J., \& Rogersion, C. M. (2014). Tourism and the mil- 
lennium development goals: Perspectives beyond 2015 . Tourism Geographies, 16(1), 23-30.

Scheyvens, R., \& Hughes, E. (2018). Can tourism help to 'end poverty in all its forms everywhere'? The challenge of tourism addressing SDG1. Journal of Sustainable Tourism, 27(7), 1061-1079.

Schliephack, J., \& Dickinson, J. E. (2017). Tourists' representations of coastal managed realignment as a climate change adaptation strategy. Tourism Management, 59, 182-192.

Scott, D., \& Becken, S. (2010). Adapting to climate change and climate policy: Progress, problems and potentials. Journal of Sustainable Tourism, 18(3), 283-295.

Scott, D., \& Brenda, J. (2007). A regional comparison of the implications of climate change for the golf industry in Canada. The Canadian Geographer, 51(2), 219-232.

Scott, D., \& Lemieux, C. (2010). Weather and climate information for tourism. Procedia Environmental Science, 1(1), 146-183.

Scott, D., Hall, S. M., \& Gössling, S. (2019). Global tourism vulnerability to climate change. Annals of Tourism Research, 77, 49-61.

Sinatra, G. M., Kardash, C. M., Taasoobshirazi, G., \& Lonbardi, D. (2012). Promoting attitude change and expressed willingness to take action toward climate change in college students. Instructional Science, 4o(1), 1-17.

Stern, P. C., \& Oskamp, S. (1987). Managing scarce environmental resources. In D. Stokols \& I. Altman (Eds.), Handbook of environmental psychology (pp. 1044-1088). Wiley.

Torres-Bagur, M., Palom, A. R., \& Vila-Subirós, J. (2019). Perceptions of climate change and water availability in the Mediterranean tourist sector. International Journal of Climate Change Strategies and Management, 11(4), 552569.

Trawoger, L. (2014). Convinced, ambivalent of annoyed: Tyrolean ski tourism stakeholders and their perceptions of climate change. Tourism Management, 40(1), 338-351.

Wajahat, A., Farah, S., Tafazal, K., Hui, L., Muhammad, Z., \& Kazi Sohag. (2020). A cointegration analysis of structural change, international tourism and energy consumption on $\mathrm{CO}_{2}$ emission in Pakistan. Current Issues in Tourism, $23,1-15$.

Wong, R., Jiang, M., Klint, L., DeLacy, T., Harrison, D., \& Dominey-Howes, D. (2013). Policy environment for the tourism Sector's adaptation to climate change in the South Pacific - The case of Samoa. Asia Pacific Journal of Tourism Research, 18(1-2), 52-71.

Wyss, R., \& Abegg, B. (2014). Percpetions of climate change in a tourism governance context. Tourism Management Perspectives, 11(c), 69-76.

Yi-Ping, S., Hall, M., \& Ozanne L. (2013). Hospitality industry responses to climate change: A benchmark study of Taiwanese tourist hotels. Asia Pacific Journal of Tourism Research, 18(1-2), 92-107.

\section{Appendix: Exploring Attitudes and Beliefs of Leading Managers in Tourism about the Reciprocal Impact of Climate Change and Tourism and the Effect of Climate Change on Shaping the Tourism Offer}

\section{Greetings,}

Your participation will enable insight into the attitudes and beliefs of leading managers in tourism, who are exceptionally important for implementing measures for adapting the tourism sector to climate change. This research is conducted for the purpose of preparing a doctoral thesis within the scope of the Management of Sustainable Development at the Faculty of Tourism and Hospitality Management in Opatija. As the research is oriented towards manager attitudes, we kindly ask that the questionnaire be filled by a person at a manager position in your company and/or object (owner or member of the executive or oversight board, director, head of the department for environmental protection or department of quality or similar). We guarantee that the results will only be used for academic purposes. Participation in the research is anonymous and voluntary, and the results presented will not be able to be traced to any person or company that fills in the questionnaire. Filling in the questionnaire takes about 15 minutes. Taking into consideration how precious time can be, we thank you for participating and for your contribution. Thank you for your cooperation.

Below are multiple statements concerning climate change, global warning, and the relationship between tourism and climate change. Please express the degree to which you agree or disagree with each given statement on a scale from 1 to 7, where 1 means 'I completely disagree', 4 means 'I neither agree nor disagree, and 7 means 'I completely agree with the statement. Please mark only one response to each statement.

1. Climate change is a serious global issue

2. Economy and tourism can be strengthened and employment increased by fighting climate change and a more efficient use of energy

3. The impact of tourism accommodation on pollution is negligible compared to the benefit it brings to the local community

4. Climate change in the near future will have a significant effect on shaping and developing the tourism offer in Croatia 
5. Global warming is predominantly caused by human activity

6. Global warming is caused by activities related to natural causes and climate variation regardless of human activity

7. The total impact of tourism on global warming and climate change is significantly lower than the impact from other economic activities

8. Climate change and global warming will endanger future generations

9. Global warming is not actually happening at all

10. The hotel and tourism industries are big spenders when it comes to energy and other resources

11. The tourism industry depends on a preserved environment as a resource, while, paradoxically, it negatively affects the environment at the same time

12. Environmental protection, in the sense of reducing global warming, is paramount for the sustainable development of tourism

13. It is important that the Government sets national goals for increasing the use of renewable energy such as wind or solar energy

14. Implementing the principles of sustainable development in business practices is an important source of competitive advantage

15. Scientists do not have a clear answer regarding what causes global warming

16. It is important that the Government continuously secures resources on the national level to support programmes for raising energy efficiency

17. Climate change is already significantly defining and changing the development of tourism offers worldwide

18. Climate change could endanger myself personally or my family

19. Climate change causes insecurity regarding successful business in tourism

20. An individual is powerless and helpless in the battle against climate change

21. Pollution is an unavoidable consequence of development

22. Even if climate change is happening, changes in the environment, such as a rise in average temperature, are so slow that there is no reason to be concerned

23. Over the last six months, I personally supported or participated in activities focused on mitigating climate change

24. When making a choice for purchasing a new vehicle, low fuel consumption and ecological parameters are more important to me than the vehicle's price
25. When building a new object or refurbishing an existing object, it is important for me to be guided by the concept of low energy consumption, regardless of higher initial investments

26. When choosing an energy supplier, if I had the choice, I would choose the supplier providing a higher percentage of power from renewable sources, regardless of higher prices

27. I try to reduce packaging waste by buying products with recyclable packaging

28. I try to buy local food products from local producers, even though the market offers cheaper products from other producers or imported products

29. When buying a new electronic or household appliance, I choose primarily based on energy efficiency and energy class

30. Every day I try to reduce water and energy consumption

On a scale from 1 to 7 , please mark to which degree thinking about climate change and global warming causes you to feel the stated emotions, where a mark of 1 means 'does not cause the stated emotion at all,' while a mark of 7 means 'very strongly causes the stated emotion.'
31. Fear
32. Anger
33. Helplessness
34. Indifference
35. Anxiety
36. Excitement

Here are some statements regarding global issues around the world, including climate change. Please answer the following questions by selecting one or more of the answers provided.

37. Which of the following problems do you consider to be the currently most serious issue that the world is facing? (Note: Please select only one answer.)
a) Climate change
b) International terrorism
c) Poverty, famine and lack of drinkable water
d) Spread of infectious diseases
e) Economic crisis
f) Proliferation of nuclear weapons
g) Armed conflicts and the refugee crisis
h) Global increase of population
i) None of the above
j) I cannot answer the question

38. What else, in addition to your answer to question 37 , do you consider to be serious issues that the world is 
currently facing? (Note: Please select no more than three answers from options 1-9, or one answer from options 10 or 11.)
a) Climate change
b) International terrorism
c) Poverty, famine and lack of drinkable water
d) Spread of infectious diseases
e) Economic crisis
f) Proliferation of nuclear weapons
g) Armed conflicts and the refugee crisis
h) Global increase of population
i) Recession and economic crisis
j) None of the above
k) I cannot answer the question

39. According to your opinion, who in the $\mathrm{EU}$ is the most responsible for the struggle against climate change? (Note: Please select only one answer.)
a) National governments
b) European Union
c) Regional and local governments
d) Individual people
e) Environmental groups and movements
f) Global corporations
g) Someone or something else
h) All of the above
i) None of the above
j) I cannot answer the question

40. The following list contains procedures and activities that can be done to reduce energy consumption and affect climate change. Please select all options that ... what?

a) Primary waste selection and separation for collection

b) Automatic air conditioning control when opening windows in accommodation units

c) Limiting the temperature in accommodation units during the day and at night

d) Reducing external ambient lighting late at night

e) Reducing energy consumption (sauna temperature, jacuzzi, air temperature and similar) in wellness and spa zones at times when there are no guests

f) Driving vehicles that use renewable energy sources for transporting guests and goods within the accommodation complex g) Availability of bicycles and similar means of transportation to reduce the use of cars in place of residence

h) Limiting the use of chemical products when maintaining property

i) Implementing a programme for reusing bed linen and towels in agreement with guests

j) Installing reduction valves, sinks and showers that save time and water

k) Securing a part of the energy requirements from own sources (solar panels and similar)

1) Encouraging guests to reduce waste generation concerning unused food and leftovers from meals

m) Recycling and reusing waste whenever possible

n) Purchasing food products from local suppliers whenever possible

o) Donating scrapped equipment, technology, furniture, consumable supplies and similar to the local community

p) Redistributing excess food to employees or the local community

q) Designing leaflets to remind guests to use resources (energy, food, water,...) responsibly

Please describe the characteristics of the tourism object in which you hold the manager position

- Location of object

1. Adriatic Croatia

2. Continental Croatia

- Type of business

1. Seasonal business

2. Year-round business

- Size of object

1. Small ( $\leq 50$ rooms/units)

2. Medium (51-100 rooms/units)

3. $\operatorname{Big}(>100$ rooms/units)

- Available pool, fitness, spa and/or wellness or similar

1. Yes

2. No

- Category

1. 2-star

2. 3-star

3. 4-star

4. 5-star

- Type of object

1. Hotel or resort hotel 
2. Holiday village

3. Camp

4. Marina

- Primary reason for guests coming to your object

1. Congress/business tourism

2. Rest and recreational tourism

3. Health and wellness tourism

4. Other

- Type of guests

1. Individual guest

2. Family guests

3. Organized groups

4. Other

- Type of ownership

1. Individual object

2. Part of a larger chain of tourism objects (part of domestic or international corporation or group)

3. Other

- Having a written Environmental Protection Policy, either as an individual document or as part of a currently valid quality assurance certificate.

1. Yes

2. No

Sociodemographic information about the participant

- Gender

1. Male

2. Female
- Education level
1. Middle
2. Higher, undergraduate
3. High
4. Postgraduate degree

- Membership in pro-environmental organization or active environmental activism

1. Yes

2. No

- Years of work experience in tourism

1. Less than 5 years

2. 5-15 years

3. More than 15 years

- Participant's level of responsibility

1. Executive or Oversight Board member/Member of object's strategic management or owner group

2. Director/Object manager/Member of object's operative management

3. Head of Quality/Head of Environmental Protection

4. Middle management

5. Other 


\title{
A Study of Barriers to Environmentally Sustainable Practices in Hotel Businesses in Punjab, India: Preliminary Findings
}

\author{
Baljit Kaur \\ KC Institute of Hotel Management, Punjab, India \\ baljitkro1@gmail.com
}

This primary study was aimed at exploring the critical barriers to environmentally sustainable practices (E S PS) and suggestions to overcome them in the context of hotel businesses. The study used a quantitative research technique, and the questionnaire was developed with the help of a thorough literature review, content analysis, and pilot study. A total of 221 responses were collected from the managers and executives of 88 classified hotels in Punjab. The 202 usable responses were analysed by descriptive analysis and Kendall's W test. The results indicated that initial implementation cost, high cost of certification, complicated certification process, lack of awareness of the concept, weak legislation, change of routines and management style, existing non-supportive structure, and low top-management commitment significantly affect the adoption and implementation of ESPS. Kendall's W test found a statistically significant agreement among the respondents. This study recommended some practical implications to overcome the barriers to ESPS, such as hotel companies starting with small initiatives that require low initial investment, hotels lobbying with regional hotel associations and government to get financial support, disseminating environmental communications to employees, firm environmental monitoring methods and reward schemes by the government. This study is conducted in a small geographical area that is otherwise a well-known tourist destination worldwide and results are consistent with the findings of previous studies that were conducted globally. Future studies are suggested in larger geographical areas with a comparison of two or more states.

Keywords: hotel businesses, environmentally sustainable practices, barriers, suggestions, Punjab, India

(cc)BY-SA https://doi.org/10.26493/2335-4194.14.71-86

\section{Introduction}

The tourism business is termed as 'resource hungry' (Sharpley, 2009) as it requires a significant amount of natural resources both at the developmental and operational levels (Knowles et al., 1999; Michailidou et al., 2015). Hotels and other accommodation sectors are the main components of the tourism sector and they leave a visible impact on the surrounding envi- ronment due to their distinct operating characteristics and functions. Hotels are often accused of environmental malpractices (Weaver, 2006).

The growth of hotel businesses is associated with many adverse effects on destinations, such as excessive use of energy, water, and local commodities, huge waste production, exhausting the natural environment, etc. (Hsieh, 2012; Jones et al., 2014). These ef- 
fects are producing challenges to natural environmental conditions at the destination.

Besides being associated with the above-mentioned negative impacts, the hotel industry is considered important by states for economic purposes and the development of the quality of life of their peoples. However, developed nations have restricted the expansion of hotel businesses, keeping in view the growing consumption of water and energy and restricted natural resources. Meanwhile, in developing countries, this growth is enormous because of the abundant availability of human resources and natural wealth, in addition to less strict environmental laws (Ganiyusufoglu, 2013). The need to get economic benefits along with reducing the negative environmental effect has introduced the concept of environmental sustainability in hotel businesses. The main motivational factors behind the environmental initiatives of hoteliers are financial benefits (Musavengane, 2019), environmental concern, legislation, competitiveness, and demand from green customers as mentioned by Nair and Anantharajah (2012). Previous studies have reported the legislation and financial benefits as the most critical motivational factors for hoteliers (Rahman et al., 2012). This concept of greening is not as successful as eventually expected and is adversely affected by many barriers (Jabbour et al., 2016). Many studies have focused on barriers to operations and green operations.

However, no research study has addressed the barriers to green operations in the current study area of Punjab, India. It is important to mention that Punjab is a famous tourist destination for domestic as well as international tourists. In 2019, the total tourist arrival in the state was $48,486,730$, which included $47,385,387$ domestic tourists and 1,101,343 international tourists (Punjab Tourism, n.d.). However, the hotel industry in Punjab is responding significantly slowly even after recognizing the proven benefits of going green. Therefore, this study was conducted to study the barriers to environmentally sustainable practices in the hotel industry of Punjab.

The study contributes to earlier research in three ways. First, it provides theoretical and empirical transparency about the critical barriers that hinder the growth of ESPS in hotel businesses. Second, the study area of Punjab is understudied by researchers in relation to the dull growth of ESPS in the region. The knowledge of barriers that are pre-shaping environmental behaviour in the state will help in environmentally sustainable decision-making while contributing theoretical suggestions required for the strong and fundamental basis of individual decisions (Lawhon et al., 2013; Vagias et al., 2014 as cited by Van Riper et al., 2020). Finally, this study discloses a significant concern of the environmental research area by finding the reasons behind the gap in the intentions of proenvironmental organizations and the actual adoption and implementation of environmentally friendly activities in their operations (Kollmuss \& Julian, 2002; Schultz, 2011 as cited by Van Riper et al., 2020, and Aragon-Correa et al., 2015; Law et al., 2014; Kim et al., 2015, as cited in Chan et al., 2018).

The findings of this study also contribute ideas for stakeholders to find a way past these barriers.

\section{Literature Review}

Efforts to save the environment started in 1970, but were formally recognized during the Earth Summit in Rio De Janeiro, Brazil, in 1992. During this summit, 172 countries decided to work with an environmentally sound framework to reduce the negative impact of businesses on the environment (Grubb et al., 2019). The concept of sustainability is defined as 'development that meets the needs of the present without compromising the ability of future generations to meet their demands' (Butlin, 1989). The concept of sustainability was introduced in the hospitality industry in later stages, as initially this industry was considered harmless to the environment. The pressure of customers and stakeholders has encouraged hotels to adopt green practices in context to save the environment. Green Hotels Association (n.d.) has defined green hotels as, 'Environmentally-friendly properties whose managers are eager to institute programs that save water, save energy and reduce solid waste, while saving money to help protect our only earth!' Initially, these green practices were associated with energy, water, and waste reduction but now hoteliers have expanded their initiatives in the area of sustainable site planning, green construction, green purchasing, in- 
door air quality, green transportation, noise control, and community involvement.

Previous studies have reported that the environmental initiatives of hotels are self-regulatory and voluntary to sustain the environment, energy conservation, water management, recycling, waste reduction, and social welfare (Hsiao et al., 2014; Hoogendoorn et al., 2015). However, Sharma and Mathur (2020) stated that there is a gap between hoteliers' environmental good intentions and actual action. Hotels are found to face difficulties in adopting environmentally sustainable initiatives due to some barriers (Chan et al., 2018; Chan, 2020; Kaur, 2020).

\section{Advantages of Environmentally Sustainable Practices}

As adoption and implementation of environmentally sustainable practices are considered as the most important recent practices in all types of businesses, their influence on efficiency needs to be investigated. The key reason behind participation in a sustainable approach is to attract some sort of benefits to the organization. A study of hotels in Kuala Lumpur in Malaysia reported enhanced brand image and providing a healthy and safe ambiance to the guests as the major advantage of ESPS (Zaiton et al., 2016). This study observed that Malaysian hotels emphasize the developing positive image of the company among customers to attract financial gains. The study of hotel businesses in developing countries shows a direct link between the implementation of environmentally sustainable practices and enhanced energy efficiency and waste management techniques, environmental sustainability, and competitive advantage by cost differentiation of services (Aragon-Correa et al., 2015; MolinaAzorín et al., 2015; Singjai et al., 2018; Kularatne et al., 2019).

Studies of sustainable practices in construction, clothing, and leather companies by Resta et al. (2018) and Shurrab et al. (2019) also reported similar benefits such as enhanced business image, competitive edge, and increased fit to customers' demands. Indian pharmaceutical companies reported some other additional benefits such as the satisfaction of stakeholders, a drop in employees' turnover rate, positive feedback of customers, etc. (Gujar \& Attarwala, 2020).
The Gap in the Study

The barriers to ESPS are studied by Chan (2008), Jauhari and Rishi (2012), Kamalul Ariffin et al. (2013), Van Riper et al. (2020) and many more. However, no study tried to explore the barriers to ESPS in the context of the Punjab hotel industry. Researchers and academicians never paid attention to the slow progress of ESPS in the survey state of Punjab. The concept of ESPS in the hotel businesses is flourishing in other states of India, while Punjab is crawling with only one Ecotel certified hotel in the state. Therefore, this study was conducted to fill this existing gap by exploring the aspects that negatively affect the implementation of ESPS among the hotels in Punjab.

\section{Theoretical Background: Barriers to ESPs}

in the Hotel Industry

Previous researchers have classified the barriers as external and internal under the implementation of ESPS (Oelze, 2017; Álvarez Jaramillo et al., 2019). According to Hillary (1998), the deficiency of knowledge of environmental issues in association with lack of information and backing from government and management are a major hurdle in the implementation of ESPS, mainly in small and medium-sized organizations. Graci and Dodds (2008) stated in their study that, hotels being different in size and category, cases of going green are not readily shared among the industry. Further, this study stressed the need to share information on environmental issues and best environmental practices among different categories of hotels.

The high initial implementation cost of ESPS was found to be a major barrier in implementing the ESPS in hotels in addition to an existing non-supportive building structure that makes it difficult to implement ESPS because of the need for major infrastructural changes (McNamara \& Gibson, 2008). Also, Micioni (2009) reported that this initial high implementation cost provides financial benefits in the long run. He suggests starting with small changes initially and gradually incorporating larger changes. He further stated that these changes should be incorporated to make the environment better at the destination where the hotels exist. Hotels also face barriers such as a lack of engineers, vendors, housekeepers, landscapers, and 
managers who are familiar with the green concept.

Another major barrier to going green is the lack of demand from the customer side. The customer demand for green services can directly influence the hoteliers' intention to go green (Satchapappichit et al., 2020). Most of the customers are not conscious of the green initiatives of hotels (Han et al., 2010). Many customers associate green hotels with a lack of luxury services (Ginsberg \& Bloom, 2004; Nadia et al., 2020). The green initiative of linen reuse is often linked to the cost-cutting tool of concerned organizations and affects guests' experience, and they might select to stay in another hotel next time. The studies of environmental management in hotels and customers' attitudes towards these green practices by Amazonas et al. (2018) and Jauhari and Manaktola (2007) reported that hotel organizations are afraid to implement these practices as they believe that the initial high operational cost could not be charged to customers. A study of barriers and drivers of environmental management systems in the Lebanese food industry states that the main barrier behind the implementation of ESPS is the absence of government support and stakeholders' demand. The other reason is that Iso 14001 and other such accreditations are not a legal requirement to run a food business (Massoud et al., 2009).

In conclusion, many previous studies have recognized common items of barriers as deficiency of environmental knowledge (Saleh \& Jawabreh, 2020), lack of government support (Nyide \& Lekhanya, 2016; Tan \& Teo, 200o), deficiency of pro-environmental attitude (Kaur, 2020), deficiency of experienced human resources (Chan, 2008), initial high implementation cost and non-supporting infrastructure (McNamara \& Gibson, 2008; Chan, 2020), lack of customer demand for green services (Jauhari \& Manaktola, 2007), employees' resistance to change, weak legislation (Bhal, 2014) and the high cost and complicated procedure of green accreditation (Chan, 2020).

\section{Research Methodology}

The main objective of this study was to discover the barriers to ESPS in the hotel industry of Punjab, India. A total of 88 classified hotels were selected to meet the objective. This study used a quantitative method. The official letter about the objective of this survey was sent to all the concerned hotels in the survey area. This research paper has adopted the survey technique to collect firsthand information from the hoteliers.

\section{Research Questionnaire Development}

The research questionnaire was developed in four stages. Firstly, the researcher developed the draft of a questionnaire with 16 items to measure the construct of barriers, keeping in view the items applied in previous studies (Ayuso, 2006; Park \& Kim, 2014; Mittal, 2014). Secondly, the questionnaire was pretested in two stages to check the content validity. In the first stage, the questionnaire was evaluated by three doctorate academicians. In the second stage, the questionnaire was evaluated by two managers from the hotel industry. The researcher took prior appointments from managers according to their convenience so that feedback could be gathered. The respondents were encouraged to put remarks against the variables that were not clear to them. Most of the experts mentioned that the research questionnaire is easy to understand, but some recommended a few modifications in some questions. Overall, some problems were identified in common in both stages. Therefore, some changes were made in the wording of some questions.

In the third stage, the research instrument was pilot tested with 25 respondents. The reliability test was applied to these responses to ensure the reliability of statements and the Cronbach alpha coefficient value of 0.864 indicated satisfactory reliability for all items. A value above 0.7 is considered reliable (Pallant, 2005) and acceptable (Sekaran \& Bougie, 2016). Based on Veal (2018), the purpose of the pilot study was to test the questionnaire wording, questionnaire sequencing, questionnaire layout, understanding of questions by respondents, response rate, response time, test survey arrangements, and test analysis methods. Finally, the researcher developed the final version of the research questionnaire with 14 items to measure the barriers.

\section{Study Area and Sample}

The research study selected Punjab in India as a study area. Punjab is a famous tourist destination for religious and business purposes. This state has a range 
of hotel establishments, ranging from basic economy class to luxury class.

Thorough consideration was given to decide that the sample for the study as the selection of the entire population of all classified hotels was not feasible. The current authentic list of classified hotels was not available for the state.

At first, it was decided to select the hotels that were formally classified by the Hotel and Restaurant Approval and Classification Committee (H R ACC), but in India, hotels enjoy the voluntary decision to get a classification from HRACC, Ministry of Tourism. Most of the hotels classify themselves according to facilities and services provided to customers. In Punjab, there are only eight hotels that are classified by HRACC (as of 1oth March 2019). The data from eight hotels was not enough to develop the generalization of the result.

Finally, a list of hotels was taken from the Hotel \& Restaurant Association of North India (H R A NI) website by including as the sample all the 49 classified hotels that were registered with the organization in 2018. In addition to the census of these hotels, 39 additional hotels (having more than 10 rooms) were selected on the judgmental sample technique to collect more responses for generalizing the results.

HRAIN is the north wing of the Federation of Hotel \& Restaurant Associations of India (F H R AI).

FHRAI is a very reputable association of the hospitality industry in India. It was established in 1955 with the commitment to the progress of the hospitality industry through education, training, professional help, research, and publications. It provides an interface between industry, government, and stakeholders.

\section{Data Collection}

The responses were collected on a 5-point Likert scale ranging from $1=$ strongly disagree to $5=$ strongly agree. The respondents were asked to rate their agreement or disagreement with the item based on the significance they assign to an item (Veal, 2018), to explore the positive or negative trend towards the proposition. Responses were collected from managerial level personnel only. Following the purposive sampling techniques suggested by Creswell (2016), these respondents were selected because of their high level of par- ticipation in policy formulation and strategy planning and their awareness of ESPS. A total of 350 questionnaires were distributed in 88 classified hotels, 221 responses were obtained, and 202 responses were found usable for conducting the data analysis.

The data collected was edited, coded, and evaluated with the help of Statistical Package for Social Scientists (spss) 22.0 for Windows.

\section{Potential Items to Measure the Barriers}

Many previous researchers (Levy, 2000; Bohdanowicz, 2006; Tzschentke, 2008; Bergin, 2010; Ustad, 2010; Mittal, 2014; Chan et al., 2018; Chan, 2020) have reported barriers to ESPS that are hindering the adoption and implementation of ESPS in hotel businesses. The barriers mentioned in previous studies have reported the obstructing of the execution of ESPS in the hotel business.

The identification of the final items to measure the barrier was a careful and difficult task as the identification of well-adopted variables from previous studies was observed to be helpful for the respondents in replying more conveniently (Rowlinson, 1988).

After the literature review, content validity, pilot study, and reliability check, 14 possible barriers to ESPS were identified for this study that are listed in Table 1.

\section{The Result Analysis and Discussions}

The statistical outputs and analysis of this research study are presented in the tables on the next pages.

\section{Profile of Respondents of Punjab Hotel Businesses}

The 88 hotels that were selected for the collection of data include hotels having varying types of ownership, category, sizes, and age of the property. The response rate according to the profile of hotels has been presented in Table 2.

The small size hotels with rooms between 10 and 50 responded in great number and contributed $64.8 \%$ of responses. The two-star, three-star and four-star properties contributed $81.7 \%$ of responses. In the category of the type of ownership, locally owned and operated contributed $42.6 \%$ of responses. In the category of the 
Table 1 List of Potential Items for Barriers

\begin{tabular}{|c|c|}
\hline Barrier Factors & References \\
\hline Initial implementation cost & $\begin{array}{l}\text { Levy (2000); Tzschentke } \\
\text { (2008); McNamara and } \\
\text { Gibson (2008); Ustad (2010) }\end{array}$ \\
\hline Certification is costly & Ustad (2010) \\
\hline $\begin{array}{l}\text { Complicated certification } \\
\text { process }\end{array}$ & Ustad (2010) \\
\hline $\begin{array}{l}\text { Lack of awareness of the } \\
\text { concept }\end{array}$ & $\begin{array}{l}\text { Levy (2000); Bohdanow- } \\
\text { icz (2006); McNamara } \\
\text { and Gibson (2008); Bergin } \\
\text { (2010); Mittal (2014) }\end{array}$ \\
\hline Weak legislation & Doody (2010); Mittal (2014) \\
\hline $\begin{array}{l}\text { Change of routines and } \\
\text { management style }\end{array}$ & Ayuso (2006) \\
\hline $\begin{array}{l}\text { Existing non-supportive } \\
\text { structure }\end{array}$ & $\begin{array}{l}\text { McNamara and Gibson } \\
(2008) \text {; Ustad (2010) }\end{array}$ \\
\hline $\begin{array}{l}\text { Low top-management com- } \\
\text { mitment }\end{array}$ & Mittal (2014) \\
\hline Little guest concern & Hillary (2017) \\
\hline Guests are uncooperative & $\begin{array}{l}\text { McNamara and Gibson } \\
(2008)\end{array}$ \\
\hline Lack of professional help & $\begin{array}{l}\text { Barnes (2007); Ustad (2010); } \\
\text { Mittal (2014) }\end{array}$ \\
\hline Limited green technology & Ustad (2010) \\
\hline $\begin{array}{l}\text { Uncertain and/or insignif- } \\
\text { icant economic advantage; } \\
\text { slow return on investment }\end{array}$ & $\begin{array}{l}\text { Revell and Blackburn } \\
\text { (2007); Ustad (2010) }\end{array}$ \\
\hline $\begin{array}{l}\text { Ineffective and/or non- } \\
\text { enforcement of laws; cor- } \\
\text { ruption; inadequate moni- } \\
\text { toring mechanism }\end{array}$ & Mittal (2014) \\
\hline
\end{tabular}

age of respondent hotels, the properties aged between 3-10 years contributed $61.38 \%$ of responses.

In conclusion, it is found that locally owned, small, and medium sized hotel businesses from two to fourstar categories in the age group of three to ten years contributed maximum responses to the data.

\section{Ranking of Barriers}

Each item is evaluated by combing the responses of hoteliers on a 5-point Likert scale where $1=$ strongly
Table 2 Response Rate According to Profile of Hotel Businesses

\begin{tabular}{|c|c|c|c|}
\hline Category & Item & $f$ & $f(\%)$ \\
\hline \multirow{6}{*}{$\begin{array}{l}\text { Number of } \\
\text { rooms in } \\
\text { respondent } \\
\text { hotels }\end{array}$} & $10-25$ & 73 & 36.1 \\
\hline & $26-50$ & 58 & 28.7 \\
\hline & $51-75$ & 39 & $19 \cdot 3$ \\
\hline & $76-100$ & 11 & 5.4 \\
\hline & $>100$ & 21 & 10.4 \\
\hline & Total & 202 & 100 \\
\hline \multirow{7}{*}{$\begin{array}{l}\text { Category of } \\
\text { respondent } \\
\text { hotels }\end{array}$} & One star & 2 & 1.0 \\
\hline & Two Star & 49 & $24 \cdot 3$ \\
\hline & Three Star & 61 & 30.2 \\
\hline & Four Star & 55 & 27.2 \\
\hline & Five Star & 29 & 14.4 \\
\hline & Five Star Deluxe & 6 & 3.0 \\
\hline & Total & 202 & 100 \\
\hline \multirow{4}{*}{$\begin{array}{l}\text { Type of } \\
\text { ownership } \\
\text { of } \\
\text { respondent } \\
\text { hotels }\end{array}$} & $\begin{array}{l}\text { Part of an international chain } \\
\text { or group }\end{array}$ & 67 & 33.2 \\
\hline & $\begin{array}{l}\text { Part of a locally operated } \\
\text { chain or group }\end{array}$ & 49 & $24 \cdot 3$ \\
\hline & Locally owned and operated & 86 & 42.6 \\
\hline & Total & 202 & 100 \\
\hline \multirow{8}{*}{$\begin{array}{l}\text { Age of } \\
\text { respondent } \\
\text { hotels }\end{array}$} & 2 years or less & 23 & 11.38 \\
\hline & 3 to 5 years & 46 & 22.77 \\
\hline & 6 to 10 years & 78 & 38.61 \\
\hline & 11 to 15 years & 28 & 13.86 \\
\hline & 16 to 20 years & 13 & 6.43 \\
\hline & 21 to 25 years & 2 & 0.99 \\
\hline & 26 years or more & 12 & 5.94 \\
\hline & Total & 202 & 100 \\
\hline
\end{tabular}

disagree, 2 = disagree, 3 = neither agree nor disagree, 4 = agree, $5=$ strongly agree. Each result is evaluated by the mean and normalized values that represent the respondents' view of each item.

Those hotels that were following ESPS in operations as well as those that had yet to implement them reported the following significant barriers. The initial implementation cost was reported as the most significant barrier with a mean value of 4.40 and $\mathrm{SD}=$ 0.65 , followed by the cost of certification with a mean 
Table 3 Ranking of Barriers Concerning the Implementation of ESPS

\begin{tabular}{|c|c|c|c|c|}
\hline Barriers & (1) & (2) & (3) & (4) \\
\hline Initial implementation cost & 4.4010 & 0.65608 & 1 & $1.00^{\star}$ \\
\hline Certification is costly & 4.2723 & 0.79808 & 2 & $0.85^{*}$ \\
\hline $\begin{array}{l}\text { Complicated certification } \\
\text { process }\end{array}$ & 4.2574 & 0.74183 & 3 & $0.83^{*}$ \\
\hline $\begin{array}{l}\text { Lack of awareness of the } \\
\text { concept }\end{array}$ & 4.2426 & 0.80147 & 4 & $0.81^{\star}$ \\
\hline Weak legislation & 4.1733 & 0.81934 & 5 & $0.73^{*}$ \\
\hline $\begin{array}{l}\text { Change of routines and } \\
\text { management style }\end{array}$ & 4.1287 & 0.80004 & 6 & $0.68^{\star}$ \\
\hline $\begin{array}{l}\text { Existing non-supportive } \\
\text { structure }\end{array}$ & 4.1188 & 0.88421 & 7 & $0.67^{*}$ \\
\hline $\begin{array}{l}\text { Low top-management com- } \\
\text { mitment }\end{array}$ & 4.0594 & 0.82041 & 8 & $0.60^{*}$ \\
\hline Little guest concern & 3.9356 & 0.78596 & 9 & 0.45 \\
\hline Guests are uncooperative & 3.7970 & 0.84841 & 10 & 0.29 \\
\hline Lack of professional help & 3.7525 & 0.94533 & 11 & 0.23 \\
\hline Limited green technology & 3.6931 & 0.97473 & 12 & 0.16 \\
\hline $\begin{array}{l}\text { Uncertain and/or insignif- } \\
\text { icant economic advantage; } \\
\text { slow return on investment }\end{array}$ & 3.6931 & 0.85510 & 13 & 0.16 \\
\hline $\begin{array}{l}\text { Ineffective and/or non- } \\
\text { enforcement of laws; corrup- } \\
\text { tion; inadequate monitoring } \\
\text { mechanism }\end{array}$ & 3.5545 & 0.91939 & 14 & 0.00 \\
\hline
\end{tabular}

Notes Column headings are as follows: (1) mean, (2) standard deviation, (3) Rank, (4) normalized value.

value of 4.27 and $\mathrm{SD}=0.79$. The third most influential barrier was the complicated certification process with a mean value of 4.25 and $S D=0.74$. Lack of awareness of concept remained in 4th place with a mean value of 4.24 and $\mathrm{SD}=0.80$. The following four barriers remained in 5 th, 6 th, 7 th, and 8th place respectively: weak legislation with mean value 4.17 and $\mathrm{SD}=$ 0.81 (place 5), change of routine and management style with mean value 4.12 and $\mathrm{SD}=0.8 \mathrm{O}$ (place 6 ), exiting non-supportive structure with mean value 4.11 and $\mathrm{SD}=0.88$ (place 7 ) and low top-management commitment with mean value 4.05 and $\mathrm{SD}=0.82$ (place 8 ). The remaining barriers were not found to be sig-
Table 4 Kendall's W Test Statistics

\begin{tabular}{lr}
\hline$N$ & 202 \\
Kendall's W* $^{*}$ & 0.101 \\
Chi-square & 264.864 \\
Degrees of greedom & 13 \\
Asymp. significance & 0.000
\end{tabular}

Notes ${ }^{\star}$ Kendall's coefficient of concordance.

nificantly important in hindering the implementation of ESPS in the survey area.

\section{Kendall's W Test}

Kendall's W test is a normalization of the statistic of the Friedman test and is applied to evaluate the tendency of agreement between the respondents. Kendall's W ranges from value $o$ to value 1 where value 1 represents complete agreement among the respondents and value o denotes complete disagreement. Intermediate values indicate the greater or lesser degree of agreement among the respondents. The Kendall's W value 0.101 and the significance level of Kendall's W at 0.000 indicate statistically significant agreement between respondents about the barrier items to ESPS. The Kendall $\mathrm{W}$ test and mean ranking of barriers to ESPS yielded some very interesting results in context of the actual adoption and execution of ESPS in the hotel businesses of Punjab. Some barriers were not found to be critical in the actual implementation process of ESPS while others played a vital role behind it, as per the reporting of respondent hoteliers.

\section{Discussion}

The identified critical barriers consistent with previous studies are discussed below.

\section{Initial Implementation Cost}

The result of this study reported the initial high implementation cost as the most influential barrier behind the implementation of ESPS. According to Ann et al. (2006), the implementation cost includes document completion, the process of modification, adoption, and implementation of the concept, hiring of professional staff, training of existing staff, procuring of related computer software, etc. It is difficult to go green 
without a sound financial foundation. Thus, the initial implementation cost was ranked among the top eight barriers. The findings are consistent with a previous study (Rowe, 2018) that also reported a high implementation cost as a significant barrier to ESPS.

Chan (2008 as cited by Calvache \& Evra, 2008) reported the opinion of hoteliers about the cost related to greening the organizations as follows:

- 'It is too expensive to install energy and water efficient equipment.'

- 'Our financial resources have a significant influence on the type and scale of pro-ecological initiatives undertaken.'

- 'Pro ecological initiatives are too expensive, although profitable in the long run. That is, in well-organized countries there are special finance schemes available, such as grants, loans, tax reductions, and other economic incentives. These are economic aspects that play decisive roles in the decision-making process concerning environmentally oriented solutions.'

The adoption and implementation of ESPS were found to be associated with the availability of financial resources. According to previous studies as discussed in earlier chapters, the infrastructure cost goes up by 10 to $15 \%$ if the building is to be made green to meet the accreditation guidelines of certifying agencies.

The above findings indicate that there are significant costs associated with start-up as well as maintenance of the Environmental Management System (EMS) and this is the most significant barrier behind the application process. To overcome this barrier, financial institutions and banks should provide easy and flexible grants and loans for implementing sustainable technologies in the business. For example, in Hong Kong, the banks are providing easy loans for the development of green projects (Gou et al., 2013). It is also necessary to intimate here that the initial cost of implementation of ESPS must be compared against the tangible and intangible payback in the future.

\section{Certification is Costly}

The certification cost is found to be the second most influential barrier by the managerial responses. The respondents were guided to mark the answers on a Likert scale and most respondents agreed that getting the green accreditation certificate is a costly affair. The studies of Ayuso (2006) and Verma and Chandra (2018) reported that different green certifying agencies have different processes and fees for getting the accreditation and there is a lack of standardized process. In addition to this, recertifying is also very costly and some certifications need to be renewed every year. In conclusion, it is found that getting the green certification is a costly affair and even the renewal cost is so significantly high that it is beyond the limit of medium and small organizations. In Punjab, most of the hotels are under the category of medium and small businesses and face a lack of financial resources in the context of getting the green certification.

\section{Complicated Certification Process}

In this study, the third most reported barrier was the complicated process of getting a green certification. The green concept is a continuous process that needs regular management and evaluation for the effective implementation and actual environmental sustainability at the destination. The research studies of Chan and Wong (2006) and Ann et al. (2006) stated five basic principles for the effective implementation of ESPS in the organization: (1) commitment towards environment and policy formulation, (2) planning the environmental actions, (3) adoption and practicing of environmental actions, (4) evaluation and correction of action, (5) management review. All the abovementioned principles require lots of paperwork, time devotion, and commitment of top management for effective working. Thus, it is concluded that getting the certification and maintaining its effective working is a complicated and difficult process that requires extra time devotion of management and other concerned staff, making it difficult to adopt and implement in addition to routine working.

\section{Lack of Awareness of the Concept}

According to the result of this study, less awareness of the green concept and the benefits associated with its implementation was the fourth most reported barrier. Inconsistent with this result, Chan (2008) and Graci 
and Dodds (2008), in their studies, found a lack of knowledge of the green concept to be a critical barrier. As the concept of environmental sustainability is at a growing stage in India, most of the hotels' managers reported a lack of knowledge of the concept.

Educating customers and industry people about the environmental issues and benefits of implementing ESPS in business would help to boost the acceptance and actual execution of environmental sustainability in the companies. For achieving this purpose there is a requirement of disseminating the environmental information among the stakeholders employing research literature, seminars, conferences, and print media, etc.

\section{Weak Legislation}

In this study, weak legislation is found to hinder the implementation of ESPS. The findings reported that hotel managers observe weak legislation to be an important barrier behind the implementation of ESPS. Most of the respondents reported that hotel businesses do not take environmentally sustainable initiatives because of the lack of environmental legislation and regular environmental inspection by government agencies. This observation is consistent with the results of Mittal (2014), who reported weak legislation as the most important barrier behind the implementation of ESPS. According to Chan et al. (2018), the hotel businesses would meet the terms of expectations regarding environmental sustainability if well defined in the form of legislation requirement.

The findings suggest that government agencies, through legislation and power to pressurize the hotels to implement the ESPS, can stimulate the environmental decisions of organizations. Hotel businesses that are lacking in the effective implementation of ESPS should be suitably punished by imposing penalties for the same.

\section{Change of Routine and Management Style}

Another significant barrier behind ESPs' implementation is the resistance to change of deep-rooted oldstyle routine and management. This barrier is found to have a close association with other barriers such as initial implementation cost, the lack of awareness of the concept, lack of professional experts, etc. In the context of this study, this factor is considered as a moderately critical (not the utmost critical) barrier. This factor received an average response from managers, and the reason may be associated with the fact that respondents were not willing to accept this factor to be associated with them. Most hotel managers work in conventional ways and are not comfortable in changing their way of working. Moreover, the hotel industry is a completely commercial sector and managers are paid to earn profits for the organizations. Therefore, managers do not propose changes to top management that require huge investments and change in conventional routine work. The findings are consistent with the previous studies of Köseoglu et al. (2018) and Okumus et al. (2017) which stated that change-resistance is a significant barrier in the environmental sustainability process.

\section{Existing Non-Supportive Structure}

This factor received an average response, neither too high nor very low by the respondent managers. The implementation of environmentally sustainable actions requires many infrastructural alterations in the existing buildings, such as installation of water and energy conservation fixtures and equipment, solar energy systems, rainwater harvesting, installation of vacuum-sealed double-glazed windows, etc. These infrastructure changes are also associated with significant expenses. In this study, 13 percent of sample hotel properties were more than fifteen years old with conventional infrastructure features. The reason for the average response for this barrier might be the lack of awareness in the respondents about the infrastructure changes required to introduce the ESPS in the organization. The significance of this barrier is also reported by Mak and Chang (2019).

\section{Low Top Management Commitment}

The item 'low top management commitment' received an average response by the managers of respondent hotels. Respondents do not feel that top management is less devoted to the adoption of ESPS in the organization. The slow progress of the green hotels may be 
linked to the non-popularity of the concept in the region rather than associating it with low support of top management.

Summary: To sum up, it is stated that the acceptance and implementation of ESPS in hotel organizations have gained a high level of attention globally. However, the adoption of this concept in Asian countries like India is still at the beginning stages and facing many barriers. These barriers should be overcome to boost the growth of the environmental sustainability concept in the hotel industry. This research study was an attempt to identify the barriers which are hindering the acceptance and actual implementation of the environmental sustainability concept in the region. The study applied a survey method to collect the overall 202 responses. There are two categories of barriers, significant and non-significant. The variables having Normalized Value more than 0.50 were considered significant and variables having Normalized Value lower than 0.50 were considered as non-significant. The findings reported that 8 out of 14 barriers were significantly hindering the acceptance and execution process of ESPS in the hotel businesses. The most significant barriers were identified as initial implementation cost; the cost of certification; complicated certification process; lack of awareness of the concept; weak legislation; change of routine and management style; existing non-supportive structure; and low top management commitment towards the concept.

However, the rest of the barriers such as little guest concern; guests are un-cooperative; lack of professional help; limited green technology; uncertain and/ or insignificant economic advantage; slow return on investment; ineffective and/or non-enforcement of laws/corruption/inadequate monitoring mechanism were not found to be significant in hindering the process of adoption and implementation of ESPS.

Suggestions to overcome these barriers are provided in Table 5.

\section{Managerial Implication}

It is clear from the findings that knowledge of critical barriers is important to ensure the effective implementation of ESPS and to sustain the natural environment. The barrier of initial investment and high cost of certi- fication is important during ESPS' adoption and hotel businesses need to focus on the development of financial resources.

The implication of this study will help the local government and hotel businesses in Punjab to understand the critical barriers that might hinder the process of establishing the actual ESPS. The stakeholders can prepare strategies well in advance to overcome these barriers. It is also necessary to enhance the environmental knowledge of hoteliers. This research can be extended to understand the difficulties faced by different categories of hotels in implementing the ESPS in their organizations.

The findings of this study help to adopt and implement the ESPS more easily in hotel businesses in the small tourist states. This research can be very informative to the businesses that need to change their conventional way of operations to ESPS. However, all the barriers cannot be removed at the same time but should be removed one after another.

\section{Opportunities for Implementation of Environmentally Sustainable Practices for Hotel Business in Punjab, India}

The adoption and implementation of ESPS are understood not only as having high initial cost but potentially associated opportunities also. These results indicate that ESPS' benefits go further beyond the initial high implementation costs. Regulatory compliance is found as the most important benefit in addition to awards and appreciations at different levels and favourable guest behaviour. The reduced health risk and accidents are also reported by Sangle and Shitole (2017). Previous research studies have identified numerous opportunities associated with the implementation of ESPS in organizations, such as competitive edge, cost savings, customer loyalty, employee retention, legal compliance, social responsibility and risk management, etc. Punjab has a huge array of hotels located in the state that cater to the needs of tourists. According to an article of The Hindustan Times (a renowned newspaper of India), Punjab holds 12th position in India in the context of overall tourist arrival in the state as cited by Sharma (2017). This sample state earned 224 million USD in 2012 from tourists, 
Table 5 Possible Approaches to Overcome the Barriers

\begin{tabular}{|c|c|}
\hline Barriers & Possible approaches \\
\hline Initial implementation cost & $\begin{array}{l}\text { Hotel companies can start with small initiatives that require low initial investment } \\
\text { such as using energy-efficient lighting, low-pressure taps and showerheads, reduce } \\
\text { and reuse waste, etc. The active involvement of the engineering department can also } \\
\text { help minimize the implementation cost (Chan et al., 2018). }\end{array}$ \\
\hline Certification is costly & $\begin{array}{l}\text { Hoteliers to work with hotel associations to lobby with the government to suggest } \\
\text { financial support for the adoption and implementation of ESPS (Cheung \& Fan, } \\
\text { 2013). }\end{array}$ \\
\hline Complicated certification process & ESPS consulting is suggested (Miles et al., 1999). \\
\hline Lack of awareness of the concept & $\begin{array}{l}\text { Hotel organizations should share environmental knowledge with counterparts (Chan } \\
\text { et al., 2018). }\end{array}$ \\
\hline Weak legislation & $\begin{array}{l}\text { The government should introduce some effective and firm environmental laws for } \\
\text { businesses and offenders should be punished strictly. In India, the Environmental } \\
\text { Impact Assessment (E IA) } 2006 \text { needs to be more effective (Bhal, 2014). }\end{array}$ \\
\hline $\begin{array}{l}\text { Change of routines and manage- } \\
\text { ment style }\end{array}$ & $\begin{array}{l}\text { Develop an environmental vision by disseminating information on environmental } \\
\text { issues of non-sustainable behaviour as suggested by Yuriev et al. (2018). }\end{array}$ \\
\hline Existing non-supportive structure & $\begin{array}{l}\text { The green certification of existing buildings (Indian Green Building Council, n.d.) } \\
\text { does not require major infrastructural changes. }\end{array}$ \\
\hline $\begin{array}{l}\text { Low top-management commit- } \\
\text { ment }\end{array}$ & $\begin{array}{l}\text { Managers can convey the tangible benefits of implementing ESPS to owners/top } \\
\text { management (Chan et al., 2018). }\end{array}$ \\
\hline
\end{tabular}

while it devoted only $0.19 \%$ of the state budget towards tourism activities. The domestic tourist arrival in the state was 2.57 crores in 2015 as compared to 1.05 crores in 2010. Similarly, the international tourist arrival has also seen a rise and was 2.42 lakh as compared to 1.37 lakh in 2010 (Sharma, 2017). The research study of Singh and Singh (2017) observed a significant contribution of the service sector to the Gross State Domestic Product (GSDP) in the state, and hotel and restaurant businesses were found to play an important role within this service sector's contribution. As this sector plays a significant role in the economy of the sample state, its growth cannot be suggested to stop. So, it is found that the implementation of ESPS in hotel businesses in Punjab is of foremost importance for the achievement of both the survival of the industry and maintaining the sustainability of the environment.

\section{Limitations and Suggestions}

This empirical study has some limitations also. Data was collected by a quantitative research questionnaire from hoteliers in Punjab and thus are not broadly generalizable. The data collected was limited to the hotel managers' views on the barriers to ESPS.

Despite the small size sample, this research study should be seen as a primary step in exploring the observed barriers behind the implementation process of ESPS, and that stimulates the curiosity of other researchers to carry out confirmatory research with larger geographical area and sample size to validate the conclusions of this study.

This study has not explored the effect of the size of hotels, ownership style of hotels, or category of hotels as barriers to ESPS. Further studies can evaluate the effect of these characteristics on the adoption and implementation of ESPS.

The barriers identified in this study have proven influence on the adoption and implementation of ESPS but not on environmental attitudes. Future research is thus suggested to explore whether these barriers affect hoteliers' environmental attitudes and if so, the ways to overcome them should be studied.

The recommendations given in this study to over- 
come the various barriers need more details that are possible with additional research. Future research should explore the success rate of these recommendations and build strong execution plans for businesses that want to incorporate ESPS in their organizations.

\section{Conclusion}

The tourism or the hotel industry is a people-oriented industry and thus the impact of the individual hotel is not the direct focus of the environmentalist or researchers and this results in the slow adoption rate of ESPS. Besides this, hotel businesses vary in sizes and star classification, thus business cases of ESPS are not voluntarily shared among businesses. The same problem has been discussed in many international conferences such as The Responsible Travel and Tourism Forum 2008, The International Ecotourism Society Eco and Sustainable Tourism Summit 2008, and The Tourism Industry Association of Canada Sustainability Forum 2008.

To make the Punjab hotel industry more environmentally sustainable, many barriers need to be overcome, such as financial crunches, weak legislation, low top management commitment, existing infrastructure, lack of organized information, and conventional work methods.

There is a need to share information about best green practices by established businesses with small and medium-sized hotel organizations to guide them to move forward towards greening the business. There is a need for a top-down approach starting from strict environmental legislation to involvement of top management to final implementation strategies. The hotel managers need to change their conventional methods of work and realize that some ESPS are practical, easy to implement, and cost-effective, and can reduce environmental impact and attract financial gains to organizations, too. Besides this, because the composition of the Punjab hotel businesses is complex and uneven due to various sizes, clientele, type of ownership, locations, and influences of stakeholders, an action plan of information-sharing regarding best ESPS and benefits associated is required for effective implementation of the green concept. Policymakers, managers, and other operational staff need to develop a positive envi- ronmental attitude and work collectively to achieve a country-wide environmental commitment. Currently, hotel businesses are self-driven towards environmental sustainability rather than demand-driven. The environmental commitment ensures competitive advantage and improved business performance that leads to reduced costs, improved brand image, and future alignment with customer demand. The hotel businesses need to move forward to sustain the environment and to safeguard the future of the industry itself.

The green issues, sustainability, environmental management, and corporate social responsibility are the key issues of future research in the field of hospitality. Responding to the call for research in these key areas, the results of the current study not only help in filling the research gap by identifying the barriers behind the implementation of ESPS in the developing countries and contributing to theoretical knowledge but also offer a valued foundation for policymakers and stakeholders to take suitable actions to mitigate the barriers related to the implementation of ESPS and subsequently promoting the environmental sustainability concept in the hotel businesses.

\section{References}

Álvarez Jaramillo, J., Zartha Sossa, J., \& Orozco Mendoza, G. (2019). Barriers to sustainability for small and medium enterprises in the framework of sustainable development - Literature review. Business Strategy and the Environment, 28(4), 512-524.

Amazonas, I., Silva, R., \& Andrade, M. (2018). Environmental management in hotels: Sustainable technologies and practices applied in hotels. Ambiente \& Sociedade, 21. https://doi.org/10.159o/1809-4422asoco172r2vu18liao

Ann, G., Zailani, S., \& Wahid, N. (2006). A study on the impact of environmental management system (EMS) certification towards firms' performance in Malaysia. Management of Environmental Quality: An International Journal, 17(1), 73-93.

Aragon-Correa, J., Martin-Tapia, I., \& de la Torre-Ruiz, J. (2015). Sustainability issues and hospitality and tourism firms' strategies. International Journal of Contemporary Hospitality Management, 27(3), 498-552.

Ayuso, S. (2006). Adoption of voluntary environmental tools for sustainable tourism: Analysing the experience of Spanish hotels. Corporate Social Responsibility and Environmental Management, 13(4), 207-220. 
Barnes, F. (2007). A sustainable future starts in the present. Caterer and Hotelkeeper, 197(449), 37.

Bergin, M. (2010). Manage your environmental costs. Hotel \& Catering Review, 33-35.

Bhal, K. (2014). Environmental legislation and its implementation in India. In P. Dover, S. Hariharan, \& M. Cummings (Eds.), Proceedings of the 2nd International Conference on Management, Leadership and Governance: ICMLG 2014 (p. 43). Academic Conferences and Publishing International.

Bohdanowicz, P. (2006). Responsible resource management in hotels: Attitudes, indicators, tools and strategie [Unpublished doctoral dissertation]. Royal Institute of Technology.

Butlin, J. (1989). Our common future: By world commission on environment and development. Journal of International Development, 1(2), 284-287.

Calvache, B., \& Evra, M. (2008). Green hotels in Sweden [Unpublished master thesis]. Umeå University.

Chan, A., Darko, A., Olanipekun, A., \& Ameyaw, E. (2018). Critical barriers to green building technologies adoption in developing countries: The case of Ghana. Journal of Cleaner Production, 172, 1067-1079.

Chan, E. S. (2008). Barriers to EMS in the hotel industry. International Journal of Hospitality Management, 27(2), 187-196.

Chan, E. S. (2020). What hinders hotels' adoption of environmental technologies: A quantitative study. International Journal of Hospitality Management, 84, 102324. https://doi.org/10.1016/j.ijhm.2019.102324

Chan, E., \& Wong, S. (2006). Motivations for IsO 14001 in the hotel industry. Tourism Management, 27(3), 481-492.

Chan, E., Okumus, F., \& Chan, W. (2018). Barriers to environmental technology adoption in hotels. Journal of Hospitality \& Tourism Research, 42(5), 829-852.

Cheung, M., \& Fan, J. (2013). Carbon reduction in a highdensity city: A case study of Langham Place Hotel Mongkok Hong Kong. Renewable Energy, 50, 433-440.

Creswell, J. W. (2016). Qualitative inquiry and research design: Choosing among five (5th ed.). Sage Publications.

Doody, H. (2010, 16 June). What are the barriers to implementing environmental practices in the Irish hospitality industry [Conference presentation]. Tourism and Hospitality Research in Ireland Conference (THRIC), Shannon, Ireland.

Ganiyusufoglu, Ö. S. (2013, 23-25 September). Chinese approach to sustainable manufacturing [Conference presentation]. 11th Global Conference on Sustainable Manufacturing, Berlin, Germany.
Ginsberg, J., \& Bloom, P. (2004). Choosing the right green marketing strategy. MIT Sloan Management Review, 46 (1), 79-84.

Gou, Z., Lau, S., \& Prasad, D. (2013). Market readiness and policy implications for green buildings: Case study from Hong Kong. Journal of Green Building, 8(2), 162-173.

Graci, S., \& Dodds, R. (2008). Why go green? The business case for environmental commitment in the Canadian hotel industry. Anatolia, 19(2), 251-270.

Green Hotels Association. (N.d.). What are Green Hotels? http://greenhotels.com/index.php

Grubb, M., Koch, M., Thomson, K., Sullivan, F., \& Munson, A. (2019). The 'Earth Summit' agreements: A guide and assessment; An analysis of the Rio'g2 UN Conference on Environment and Development (Vol. 9). Routledge.

Gujar, G., \& Attarwala, A. (2020). Benefits of implementing sustainable business practices for the Indian pharmaceutical industry. Asian Journal of Management, 11(1), 26-28.

Han, H., Hsu, L., \& Sheu, C. (2010). Application of the theory of planned behavior to green hotel choice: Testing the effect of environmental friendly activities. Tourism Management, 31(3), 325-334.

Hillary, R. (1998). Pan European Union assessment of EMAS implementation. Environmental Policy and Governance, 8(6), 184-192.

Hillary, R. (2017). Small and medium-sized enterprises and the environment: Business imperatives. Routledge.

Hoogendoorn, G., Grant, B., \& Fitchett, J. (2015). Towards green guest houses in South Africa: The case of Gauteng and KwaZulu-Natal. South African Geographical Journal, 97(2), 123-138.

Hsiao, T., Chuang, C.-M., Kuo, N.-W., \&. Yu, S. M.-F. (2014). Establishing attributes of an environmental management system for green hotel evaluation. International Journal of Hospitality Management, 36, 197-208.

Hsieh, Y. C. (2012). Hotel companies' environmental policies and practices: A content analysis of their web pages. International Journal of Contemporary Hospitality Management, 24(1), 97-121.

Indian Green Building Council. (N.d.). IGBC green existing buildings O\&M. https://igbc.in/igbc/redirectHtml.htm ?redVal=showGreenExistingBuildingsnosign

Jabbour, C., de Sousa Jabbour, A., Govindan, K., De Freitas, T., Soubihia, D., Kannan, D., \& Latan, H. (2016). Barriers to the adoption of green operational practices at Brazilian companies: Effects on green and operational performance. International Journal of Production Research, 50(10), 3042-3058.

Jauhari, V., \& Manaktola, K. (2007). Exploring customer atti- 
tude and behaviour towards green practices in the lodging industry in India. International Journal of Contemporary Hospitality Management, 19(5), 364-377.

Jauhari, V., \& Rishi, M. (2012). Challenges faced by the hospitality industry in India: An introduction. Worldwide Hospitality and Tourism Themes, 4(2), 110-117.

Jones, P., Hillier, D., \& Comfort, D. (2014). Sustainability in the global hotel industry. International Journal of Contemporary Hospitality Management, 26(1), 5-17.

KamalulAriffin, N., Khalid, S., \& Wahid, N. (2013). The barriers to the adoption of environmental management practices in the hotel industry: A study of Malaysian hotels. Business Strategy Series, 14(4), 106-117.

Kaur, B. (2020). Managerial attitude and implementation of environmental sustainable practices in the hotel industry of Punjab [Unpublished doctoral dissertation]. Lovely Professional University.

Kim, S., Yoon, J., \& Shin, J. (2015). Sustainable business-andindustry foodservice. International Journal of Contemporary Hospitality Management, 27(4), 648-669.

Knowles, T., Macmillan, S., Palmer, J., Grabowski, P., \& Hashimoto, A. (1999). The development of environmental initiatives in tourism: Responses from the London hotel sector. International Journal of Tourism Research, 1(4), 255-265.

Kollmuss, A., \& Julian, A. (2002). Mind the gap: Why do people act environmentally and what are the barriers to pro-environmental behavior? Environmental Education Research, 8(3), 239-260.

Köseoglu, M., Yazici, S., \& Okumus, F. (2018). Barriers to the implementation of strategic decisions: Evidence from hotels in a developing country. Journal of Hospitality Marketing \& Management, 27(5), 514-543.

Kularatne, T., Wilson, C., Månsson, J., Hoang, V., \& Lee, B. (2019). Do environmentally sustainable practices make hotels more efficient? A study of major hotels in Sri Lanka. Tourism Management, 71, 213-225.

Law, R., Wu, J., \& Liu, J. (2014). Progress in Chinese hotel research: A review of ssCi-listed journals. International Journal of Hospitality Management, 42, 144-154.

Lawhon, B., Newman, P., Taff, D., Vaske, J., Vagias, W., Lawson, S., \& Monz, C. (2013). Factors influencing behavioral intentions for leave no trace behavior in national parks. Journal of Interpretation Research, 18(1), 23-38.

Levy, J. I. (200o). Economic incentives for sustainable resource consumption at a large university: Past performance and future considerations. International Journal of Sustainability in Higher Education, 1(3), 252-266.

Mak, A., \& Chang, R. (2019). The driving and restraining forces for environmental strategy adoption in the hotel industry: A force field analysis approach. Tourism Management, 73, 48-6o.

Massoud, M. A., Fayab, R., El-Fadel, M., \& Kamleh, R. (2009). Drivers, barriers, and incentives to implementing environmental management systems in the food industry: A case of Lebanon. Journal of Cleaner Production, 18(3), 200-209.

McNamara, K., \& Gibson, C. (2008). Environmental sustainability in practice? A macro-scale profile of tourist accommodation facilities in Australia's coastal zone. Journal of Sustainable Tourism, 16(1), 85-100.

Michailidou, A., Vlachokostas, C., \& Moussiopoulos, N. (2015). A methodology to assess the overall environmental pressure attributed to tourism areas: A combined approach for typical all-sized hotels in Chalkidiki, Greece. Ecological Indicators, 50, 108-119.

Micioni, C. W. (2009). Going green in the hospitality industry. Digital Scholarship@UNLV.https://digitalscholarship .unlv.edu/do/search/?q=author_lname\%3A\%22Micioni $\% 22 \% 20 a u t h o r \_f n a m e \% 3 \mathrm{~A} \% 22$ Christina\%22\&start $=0$ \&context $=830141$

Miles, M., Munilla, L., \& McClurg, T. (1999). The impact of Iso 14000 environmental management standards on small and medium sized enterprises. Journal of Quality Management, 4(1), 111-122.

Mittal, V. K. (2014). Prioritizing barriers to green manufacturing: environmental, social and economic perspectives. Procedia CIRP, 17, 559-564.

Molina-Azorín, J., Tarí, J., Pereira-Moliner, J., Lopez-Gamero, M., \& Pertusa-Ortega, E. (2015). The effects of quality and environmental management on competitive advantage: A mixed methods study in the hotel industry. Tourism Management, 5o(c), 41-54.

Musavengane, R. (2019). Small hotels and responsible tourism practice: Hoteliers' perspectives. Journal of Cleaner Production, 220(3), 786-799.

Nadia, E., Beatrice, C., \& Atour, T. (2020). Luxury hotels' eco-friendly activities \& customers' preferences and willingness to pay for green hotels. Journal of Advanced Management Science, 8(1), 7-14.

Nair, V., \& Anantharajah, S. (2012). A green makeover for our hotels? Environment, Development \& Sustainability, 2, 10-12.

Nyide, C., \& Lekhanya, L. (2016). Environmental Management Accounting (EMA) in the developing economy: A case of the hotel sector. Corporate Ownership \& Control, 13(4), 575-582.

Oelze, N. (2017). Sustainable supply chain management 
implementation-enablers and barriers in the textile industry. Sustainability, 9(8), 1435. https://doi.org/10.339o/ sugo81435

Okumus, F., Bilgihan, A., Ozturk, A., \& Zhao, X. (2017). Identifying and overcoming barriers to deployment of information technology projects in hotels. Journal of Organizational Change Management, 30(5), 744-766.

Pallant, J. (2005). spss Survival Manual (2nd ed.). Open University Press.

Park, J., \& Kim, H. (2014). Environmental proactivity of hotel operations: Antecedents and the moderating effect of ownership type. International Journal of Hospitality Management, 37, 1-10.

Rahman, I., Reynolds, D., \& Svaren, S. (2012). How 'green' are North American hotels? An exploration of low-cost adoption practices. International Journal of Hospitality Management, 31(3), 720-727.

Resta, B., Dotti, S., Ciarapica, F., De Sanctis, I., Fani, V., Bandinelli, R., \& Rinaldi, R. (2018). Leveraging environmental sustainability for competitive advantage in the Italian clothing and leather sector. International Journal of Fashion Design, Technology and Education, 11(2), 169186.

Revell, A., \& Blackburn, R. (2007). The business case for sustainability? An examination of small firms in the UK's construction and restaurant sectors. Business Strategy and the Environment, 16(6), 404-420.

Rowe, K. (2018). Hoteliers' perceptions of sustainable practices on small hotel optimization: A phenomenology inquiry [Unpublished doctoral dissertation]. Walden University, Minneapolis, MN.

Rowlinson, S. M. (1988). An analysis of factors affecting project performance in industrial buildings with particular reference to design build contracts [Unpublished doctoral dissertation]. Brunel University, London, England.

Saleh, M., \& Jawabreh, O. (2020). Role of environmental awareness in the application of environmental accounting disclosure In tourism and hotel companies and its impact on Investor's decisions in Amman Stock Exchange. International Journal of Energy Economics and Policy, 10(2), 417-426.

Sangle, S., \& Shitole, M. V. (2017). Study of benefits enjoyed by five star hotels due to adoption of environmental management practices. International Journal of Research in Economics and Social Sciences, 7(12), 770-779.

Satchapappichit, S., Hashim, N., \& Hussin, Z. (2020). Factors influencing adoption of green practices by small and medium sized hotels in Thailand. Journal of Business Management and Accounting, 3, 61-78.
Schultz, P. W. (2011). Conservation means behavior. Conservation Biology, 25(6), 1080-1083.

Sekaran, U., \& Bougie, R. (2016). Research methods for business: A skill building approach (7th ed.). John Wiley \& Sons.

Sharma, M. G. (2017, February 25). Rich in monuments, Punjab gets a tourism high: From 28th spot to 12th in eight years. Hindustan Times. https://www.hindustantimes .com/punjab/rich-in-monuments-punjab-gets-a -tourism-high-from-28th-spot-to-12th-in-eight-years/ story-Jm2ybgRfm4kvydeGkFLUSI.html

Sharma, S., \& Mathur, N. (2020). An assessment of attitude towards environment: A study of five star hotels in Rajasthan. International Journal of Applied Management Science, 12(2), 151-168.

Sharpley, R. (2009). Tourism development and the environment: Beyond sustainability. Earthscan.

Shurrab, J., Hussain, M., \& Khan, M. (2019). Green and sustainable practices in the construction industry. Engineering, Construction and Architectural Management, 26(6). https://doi.org/10.1108/ECAM-02-2018-0056

Singh, A., \& Singh, J. (2017). Service sector scenario of Pun$\mathrm{jab}$ and Haryana. International Journal of Research in Economics and Social Sciences, 7(7), 442-447.

Singjai, K., Winata, L., \& Kummer, T. (2018). Green initiatives and their competitive advantage for the hotel industry in developing countries. International Journal of Hospitality Management, 75, 131-143.

Punjab Tourism. (N.d.). Statistics \& surveys: Year-wise tourist visits in Punjab. https://punjabtourism.punjab.gov.in/ statistics-surveys.php

Tan, M., \& Teo, T. (200o). Factors influencing the adoption of Internet banking. Journal of the Association for information Systems, 1(5), 1-42.

Tzschentke, N. A. (2008). Going green: Decisional factors in small hospitality operations. International Journal of Hospitality Management, 27(1), 126-133.

Ustad, B. H. (2010). The adoption and implementation of environmental management system in New Zealand hotels [Unpublished doctoral dissertation]. Auckland University of Technology, Auckland, New Zealand.

Vagias, W., Powell, R., Moore, D., \& Wright, B. (2014). Predicting behavioral intentions to comply with recommended leave no trace practices. Leisure Sciences, 36(5), 439-457.

Van Riper, C., Lum, C., Kyle, G., Wallen, K., absher, J., \& Landon, A. (2020). Values, motivations, and intentions to engage in proenvironmental behavior. Environment and Behavior, 52(4), 437-462. 
Veal, A. J. (2018). Research methods for leisure and tourism (5th ed.). Pearson Education.

Verma, V., \& Chandra, B. (2018). Intention to implement green hotel practices: Evidence from Indian hotel industry. International Journal of Management Practice, 11(1), 24-41.

Weaver, D. B. (2006). Sustainable tourism: Theory and practice. Routledge.
Yuriev, A., Boiral, O., Francoeur, V., \& Paille, P. (2018). Overcoming the barriers to pro-environmental behaviors in the workplace: A systematic review. Journal of Cleaner Production, 182, 379-394.

Zaiton, S., Herman, S., Kasimu, A., \& Hassan, H. (2016). Sustainable tourism practices among hotels in Malaysia: Financial and non-financial benefits. Journal of Sustainability Science and Management, 11(1), 73-81. 


\title{
Quality of a Rural Destination: Visitor and Resident Approach
}

\author{
Kateřina Mlejnková \\ Mendel University in Brno, Czech Republic \\ katerina.mlejnkova@mendelu.cz \\ Tomáš Dania \\ Mendel University in Brno, Czech Republic \\ tomas.dania@mendelu.cz \\ Ida Rašovská \\ Mendel University in Brno, Czech Republic \\ ida.rasovska@mendelu.cz
}

Destination quality is a complex set of many factors. Methods of evaluating these factors are subject to continuous research. An evaluation of the visitors' and locals' satisfaction and using the results to manage the quality and sustainable development of the destination is a possible approach. This article applies importance-performance methodology to analyse a rural region in the Czech Republic. Using IPA analysis, the factors that most affect the satisfaction of visitors and residents are identified. The differences in the perceptions of visitors and residents are statistically significant, e.g., visitors consider the factors 'overcrowding' and 'friendly acceptance by locals' to be more important. At the same time, both groups have some awareness of the importance of sustainable tourism and the quality of services. The results indicate that in the region there are areas of improvement and performance, furthermore, they point out opportunities for the improvements mentioned. Moreover, the main difference between the performance (meaning the perceived level of quality of the service provided in the destination) and the importance of research factors has been determined. Based on the results, recommendations for destination management are formulated.

Keywords: quality, resident, visitor, rural destination, IPA

(cc)BY-SA https://doi.org/10.26493/2335-4194.14.87-99

\section{Introduction}

Tourism plays a big role in industry worldwide and it is one of the fastest-growing sectors. Usually, it is related to GNP, employment and other economic macro indicators (Politis et al., 2009). Travellers can choose from a wide variety of destinations, which implies that a destination is easily replaceable. For this reason, competitiveness between destinations is evident and the importance of tourism grows as well (Ayikoru, 2015).
For tourism destinations, competitiveness is essential, and each company or destination should find a better approach in competing with others by enhancing its products so that they gain a competitive advantage (Go \& Govers, 2000).

Quality is a factor strengthening competitiveness (Ennew et al., 1993) and influencing not only a positive perception of a service but also of an entire destination (Su et al., 2016; Weaver et al., 2007). UNW TO 
(n.d.a) defines quality as the result of a process that leads to meeting all legitimate needs, requirements and expectations of a customer concerning a service product, all this for an acceptable price in compliance with mutually accepted contract conditions and determining qualitative determinants, such as security, hygiene, availability of tourist services, transparency, authenticity and harmony of tourist activities with the human and natural environment. Determination and evaluation of destination quality is not easy due to its complexity, level of subjectivity when evaluating quality and the specific character of the services (Hudson, 2008). The quality of the destination also encompasses satisfaction of visitors, residents and other stakeholders. At the same time, emphasis is placed on the quality of the environment (European Commission, 2003). According to Ryglová et al. (2017), visitors' overall satisfaction is influenced by a set of factors constituting destination quality.

It can be stated that developing and maintaining the quality of the destination is a long-term process. Destination management often does not know visitors' important factors for and what assure their satisfaction in the destination (Rašovská et al., 2020). According to Caber et al. (2012), destination authorities and managers have to identify those destination attributes which are the most vital determining factors in customers' satisfaction. It is also advisable to examine the satisfaction of local residents. Therefore, the aim of this study is to perform an importance-performance analysis and provide valuable information for destination management.

This paper's objective is to evaluate destination quality by means of a complex set of factors applicable for destinations using importance-performance analysis (IPA), in the rural destination of the Moravian Karst in the Czech Republic. The research question, whether there is a difference in the perception of selected factors by destination between a group of visitors and residents, was formulated based on a literature review (Herrera et al., 2018). The analysis will be done separately for both residents and visitors and will clarify whether there are any differences between their perceptions of performance quality factors in the destination. The authors' aim is to determine differences in perception between tourists and residents, even in less-visited destinations that do not suffer from overtourism, and whether it is necessary to examine these groups separately. The outcome will be suggestions to boost destination quality, integrating both groups' requirements.

\section{Factors of Destination Quality}

The concept of destination is closely outlined as a target area that offers the attractiveness and infrastructure of tourism (Zelenka \& Pásková, 2012). Ryglová et al. (2015) indicate that it is appropriate to focus on detailed structure and analyse components which can be considered as determining for a destination's success. Goeldner and Ritchie (2014) define the destination as a geographically delimited area in which the visitor gets different experiences. For Bieger \& Beritelli (2012), the destination means a space, which is chosen by the visitor as a target of their journey. It must comprise of all necessary facilities for accommodation, boarding, and entertainment.

Buhalis (2003) defines five characteristic components of destination:

- Attractions (a primary offer of tourism that due to its amount, quality and attractiveness activates attendance, for instance, natural, culturalhistorical potential).

- Accessibility and ancillary services (a general infrastructure which enables access to the destination and travelling to the attractions in the destination; also, services used mainly by local inhabitants, such as telecommunication, medical and banking services).

- Amenities (superstructure and infrastructure of tourism that enable the stay in the destination and utilizing its attractions, for example, accommodation, sports- recreational, cultural-social facilities).

- Available packages (prepared products and product packages).

- Activities.

Middleton and Clarke (2001) add image and perception of the destination and price. According to some authors (Dortyol et al., 2014), individual factors 
can be grouped into categories, e.g. employees (friendliness, politeness, willingness), room equipment, food quality, material items, prices, transport, climate, hygiene and security. Milošević et al. (2016) add that within these factors, some others can be allocated, such as internet coverage, destination information, transport providers' quality, activity offer quality, medical assistance, local dwellers, destination cleanliness or level of pollution. As other authors confirm, a visitor's satisfaction with a destination is not only elicited by their experience with tourism services but also by other endogenous factors such as security, hospitality, the local population's friendliness, destination cleanliness, traffic infrastructure or the level of tourism management (Ashworth \& Page, 2011).

A destination is not just a product, but a whole system composed of several elements and relationships (Barrado, 2004). A destination strives for a complex offer of a service chain. The visitor then purchases and consumes these services in the destination. Therefore, it is possible to view a destination as a single product, consisting of many services offered to satisfy the visitors' expectations. The need to adopt quality-based strategies to develop customer service has been highlighted in service providers, where customer subjectivity plays a substantial role. It is because everyone perceives the service provided differently, and therefore, services are difficult to standardize (Caruana et al., 1999). Kotler and Keller (2007) describe service as an activity offered by one to another.

Marketing plans and promotional strategies (price, quality, image) are considered as key for destination competitiveness (Go \& Govers, 200o). Therefore, this planning process should be based on an analysis of a destination's competitive factors (Hassan, 2000). One of the possible approaches to destination quality research is to investigate visitors' satisfaction. A visitor's overall satisfaction is influenced by a set of factors constituting destination quality. These factors representing quality are the destination's primary potential (natural and cultural attractions), services provided, accessibility, destination management activities, and aspects of sustainability. At the same time, it is necessary to observe not just the functional but also the technical quality of services (Ryglová et al., 2017). In addition to determining the satisfaction of visitors, it is also important to reveal the perception of residents (Herrera et al., 2018). It is also crucial for the sustainable development of a destination to know the requirements of more than one stakeholder group (Herrera et al., 2018).

\section{Importance-Performance Analysis}

IPA is a commonly used research technique, which allows researchers and practitioners alike to understand customer satisfaction and to formulate strategies for improvements in products/services (Bi et al., 2019). This method was first introduced in the work of Martilla and James (1977) and is a basic diagnostic and decisive tool (Johns, 2001; Matzler et al., 2003) that facilitates the identification of factors with the highest priority for improvement (Sampson \& Showalter, 1999) and, according to Levenburg and Magal (2004), also the mobilization and development of the most required resources.

In one of the latest researches, Azzopardi and Nash (2013) subjected IPA to a critical analysis and, on the basis of analysing more than forty authors' works from the period of 1977-2007, they claim that despite its certain deficiencies, IPA is recommended and utilized in the area of tourist services as a method that is relatively easily applied in empirical studies. IPA and its use in literature focusing on hospitality and tourism were also studied by Lai and Hitchcock (2015), who revised analyzed nearly 60 articles and created a compact survey of the possibilities in applying IPA, without subjecting these utilizations to a critical analysis.

The authors Caber et al. (2012) use IPA for assessing destinations' attributes. The article shows empirically that market segments differ significantly within these two dimensions of the analysis, and thus it is suggested that IPA should be conducted on the segment rather than the aggregate level. Twenty quality factors have been assessed on a scale of five and a comparison of specific segments has been performed (German, British, Dutch and Russian respondents). The empirical basis of the article is laid by a sample of 821 customers in a Turkish destination. They found that IPA using an isoline of importance and performance instead of the traditional quadrant analysis yields better results and increases the diagnostic value of IPA. 
Using this tool, it is possible to identify the relative importance and performance of individual factors that have an impact on the observed quality. There are two possibilities for using the IPA analysis - data-centred (Ramakrishnan \& Usha, 2016) and scale-centred data (Tonge \& Moore, 2007). Median values which are used in the scale-centred IPA and are utilized in this article, according to some authors, tend to 'inflate' the results (Oh, 2001). When using a data-centred approach, the attributes are outlined according to their relative importance-performance (Boley et al., 2017).

\section{Methodology}

In this study, the quality of the rural area Moravian Karst in the Czech Republic and differences between the perception of visitors and residents are being investigated. The dominant attractions of this region are their interesting and valuable natural resources and scenery, caves and rock structures. Yearly, this region with fourteen caves welcomes about 360 thousand visitors (Ekolist, 2018). Since the 9os, the Moravian Karst has implemented some restrictions and only a certain number of visitors can enter. Therefore, it is not an overcrowded place. Additionally, according to the marketing strategy (Centrála cestovního ruchu - Jižní Morava, 2019), the Moravian Karst has the lowest visitor turnout and overnight stays in South Moravia.

The forms of tourism are the following: naturaloriented tourism, ecotourism, bicycle touring, hiking etc. (Pásková, 2009). The 20 factors of quality (Appendix 1) which were used in the questionnaire were formulated based on the previous researches about the quality components of the destination (Buhalis, 2003; Middleton \& Clarke, 2001; Ashworth \& Page, 2011; Ryglová et al., 2015; Milošević et al., 2016).

A questionnaire was self-administered in the region of the Moravian Karst and its surroundings in the Czech Republic using the tool quota sampling (gender, age) from August to October 2017. The data were conducted electronically on the internet and social networks, as well as through personal examination at the destination and placement at the information centres. The questionnaire was developed to understand the visitors' and residents' evaluation of the destination's quality. A range from 1 = 'not at all important/satisfied' to 5 = 'extremely important/satisfied' was used for the questions for importance/performance characteristics.

To ensure the representativeness of the questionnaire, it was necessary to determine the appropriate number of respondents. A statistical approach based on the following formula was used to determine the minimum number of respondents:

$$
n \geq \frac{z^{2} \times p \times q}{\Delta^{2}} .
$$

In this formula, $n$ is the minimum number of respondents, $z$ is the reliability coefficient, $p$ and $q$ are the numbers of respondents and the maximum permissible error (Kozel, 2006):

$$
278 \geq \frac{2^{2} \times 0.5 \times 0.5}{0,06^{2}}
$$

In the case of this questionnaire survey, the reliability coefficient was set at 2 , which corresponds to a $95 \%$ probability of assertion. According to the calculation, the minimum number of respondents is 278 . Thus, two quotas were set in advance for the selection of respondents and age and gender. According to data from the Czech Statistical Office on the age composition of the population as at 31 December 2016, a quota sample for age and sex was set.

A total of 408 respondents covering these characteristics (such as gender, age, education, and employment) were obtained, of which $50.3 \%$ were visitors and $49.7 \%$ residents. Nevertheless, a total of 94 failed to appropriately respond, leading to a total of 314 usable responses. The sample included an equal number of visitors $(50.3 \%)$ and residents (49.7\%). The detailed structure of respondents is shown in Table 1.

The data is equally distributed and accurately reflects the demographic development. Based on this, some parametric statistical methods can be used ( $t$ test). The testing was conducted at a $5 \%$ level of significance and different perceptions of factors between visitors and residents have been examined. The results in Table 2 show only statistically significant values and $p$-values.

To analyse data, Importance-performance analysis (IPA) was utilized. The analyses divide the attributes' performance and importance dimensions into four 
Table 1 Sample Characteristics

\begin{tabular}{llrr}
\hline Category & Item & Visitor & Resident \\
\hline Gender & Male & 46.8 & 51.3 \\
& Female & 53.2 & 48.7 \\
\hline Age & $18-23$ & 4.4 & 9.6 \\
& $24-30$ & 10.1 & 12.8 \\
& $31-40$ & 29.7 & 20.5 \\
& $41-50$ & 29.7 & 11.5 \\
& $51-60$ & 8.9 & 28.2 \\
& $61-70$ & 16.5 & 14.7 \\
& $>71$ & 0.6 & 2.6 \\
\hline Education & Trade school & 25.3 & 21.8 \\
& High school & 38 & 45.5 \\
& College graduate & 45.6 & 32.7 \\
\hline
\end{tabular}

Notes In percent.

Table 2 Statistically Significant Differences in the Perception of Factors between Residents and Visitors

\begin{tabular}{lllr}
\hline Factors & $(1)$ & $(2)$ \\
\hline F2 & Cultural and social attractions & Importance & 0.005 \\
& & Performance & 0.003 \\
\hline F3 & Accommodation & Importance & 0.002 \\
& & Performance & 0.006 \\
\hline F10 & Friendly acceptance & Importance & 0.002 \\
& by the locals & Performance & 0.003 \\
\hline F16 & Overcrowding of the desti- & Importance & 0.000 \\
& nation & Performance & 0.029 \\
\hline \multirow{2}{*}{ F18 } & Additional infrastructure & Importance & 0.044 \\
& & Performance & 0.004 \\
\hline \multirow{2}{*}{ F20 } & Certification of accommo- & Importance & 0.000 \\
& dation and food services & Performance & 0.025 \\
\hline
\end{tabular}

Notes Column headings are as follows: (1) perception of factors, (2) $p$-value (sig. 2-tailed).

quadrants which are easy to interpret and for acquiring practical suggestions (Dwyer et al., 2016). The four quadrants dividing quality factors are the following: 'Key Features/Keep Up the Good Work,' 'Concentrate here/Shortfalls,' 'Low priority factors' and 'Strategic/Possible Overkill.' The results of the IPA analysis are thus presented utilizing a two-dimensional graph with the average value of importance on the vertical axis and the average performance on the horizontal axis (Wong et al., 2011).

Factors represented in 'Key Features' have a very positive evaluation by clients and they have immense importance. Thus, destination management and local enterprises should keep delivering high-quality products. Factors representing 'Concentrate here' are characterized by very high importance but low performance. This means that even though the factors are important to the clients, the level of performance does not meet their requirements. Hence, it is crucial to pay more attention to these factors. Factors in 'Low priority' both show low importance and do not have a lot of impact on the performance of the destination under research. There is no need to invest either money or effort in improving these factors. The last quadrant, 'Possible overkill', characterizes the factors with low importance but high performance, which highlights the fact of excessive importance; however, visitors 'do not care' about the factor.

\section{Results}

The research aims to propose measures that will support the development of quality concerning the differences between the two groups. The suggestions are based on the IPA analysis and statistical data testing. The IPA analysis was compiled based on the average values of performance and importance of the research quality factors among visitors and residents. Performance, which was evaluated using respondents' satisfaction, has the average value of 3.97 for visitors and 3.79 for residents. Meanwhile, the significance of quality factors for the destination's visitors/residents is represented by the medium value of 3.91 and 3.72 , respectively. These two values create the centre of the coordinates that set up the four quadrants of IPA graph. Figure 1 captures the perception of 20 factors for the visitors (50.3\% of respondents), Figure 2 for residents (49.7\% of respondents).

The results show that the factors in quadrant Q1 (Key features) are not very different. Both visitors and residents consider $\mathrm{F} 13$ Level of personnel quality in tourism services, F14 Sense of security, F15 Destina- 


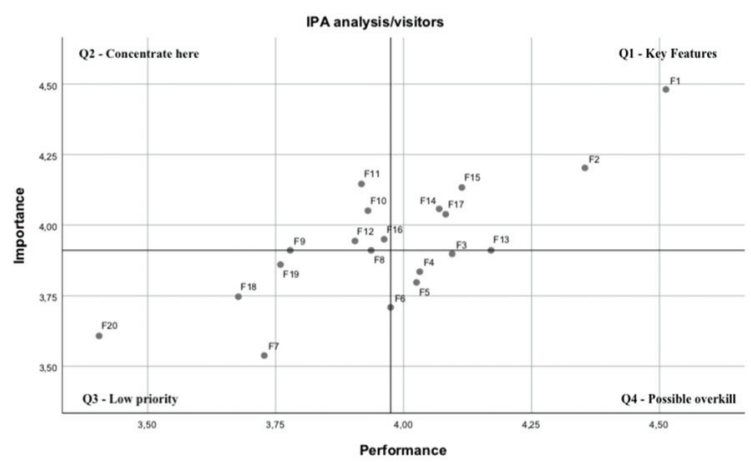

Figure 1 IPA Analysis from the Point of View of Visitors

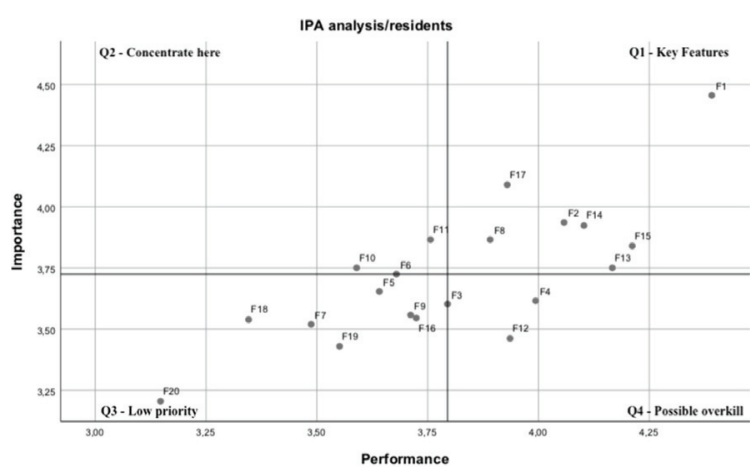

Figure 2 IPA Analysis from the Point of View of Residents

tion cleanliness and $\mathrm{F} 17$ Uniqueness of destination as factors with a high significance, while their qualitative level is positive enough. It is important to carry on improving the factors so that the performance does not decrease. F1 Natural attractions have the highest significance and highest performance for both groups of respondents. At the same time, F 2 Cultural and social attractions are evaluated with greater importance and perception for visitors. The only difference is within the $\mathrm{F} 8$ placement, Availability and quality of the information, which visitors placed in Q3, but residents in Q1.

The second quadrant, Q2 (Concentrate here), contains factors with low performance and great importance. This means that for visitors of the destination, factors such as F10 Friendly acceptance by the locals, F11 Image of the destination, F 12 Level of prices of services and goods at the destination and F16 Overcrowding of the destination are important, but the satisfaction of the level of quality is not enough. Thus, the aforementioned factors should be improved and receive priority attention. Both residents and visitors placed equally factors $\mathrm{F} 10$ and $\mathrm{F} 11$.

Another quadrant (Q3) consists of factors with low priority and low significance for visitors. It is not so important to pay too much attention to these factors, but the destination should keep in mind that some factors are changing, specifically those depending on demand, and therefore it is recommended not to underestimate them. Losing the level of quality of factors will lead to a negative overall satisfaction with the destination.

The last quadrant, Q4, is clarified as excess care of the factors which are less important for visitors/residents. As we can see in Figure 1 and Figure 2, only F 4 Food was placed by both categories of respondents to this quadrant, 'Possible Overkill.'

The biggest difference between visitors and residents is within factor F12 Level of prices of services and goods at the destination - while visitors consider this factor very important and place it in the quadrant Q2 - Concentrate here, for residents it belongs to the quadrant Possible Overkill. This detection makes sense as prices are a key factor in a decision whether to visit a destination or not.

An interesting finding is connected with factor F16 Overcrowding of the destination, where the residents consider this factor to have less importance and a lower level of perception, while for visitors, F16 is more important and perception of the quality level is higher. Nowadays, there are occurrences where masstourism is not perceived in the same way by the residents (for example, in Venice, Paris or Rome). In 1950, only 25 million tourists were travelling, in 2018 the number was 1.4 billion (Matulik, 2019). Rural areas are not particularly tourist-sought places and their residents do not meet the visitors as often as in cities. Visitors do visit the countryside and they may not even stop by in the village, or, they make one-day trips from major cities to rural destinations. This is confirmed by the questionnaire, where visitor-respondents state making mostly one-day (over 66\%), or weekend trips (2-3 days, over $22 \%$ ).

In addition to IPA analysis, independent $t$-tests 
were also conducted to verify the factors' perceptions of importance and performance. The Independent Samples $\mathrm{t}$ test is a commonly used test that determines whether there is a statistically significant difference between the means in two unrelated groups (Kim, 2015). Based on this it is possible to conclude whether differences in IPA analysis are statistically significant. Specifically, whether the position of factors in IPA graphs differs statistically in both axes $(y$ axis for importance and $x$-axis for performance). Statistically significant factors are listed in Table 2. Concerning IPA analysis, it can be said that the perception of factors included in quadrant Q1 does not differ remarkably between visitors and residents. The factor Cultural and social attractions (F 2$)$ is rated by visitors as more important ( $m=4.20$ vs. $m=3.94$ ) and more efficient ( $m=4.18$ vs. $m=3.97)$.

The factors in quadrant Q2 statistically differ in both axes. Especially, the factors Friendly acceptance by the locals (F1O) and Overcrowding of the destination (F16) are rated more important by visitors. There is a significant difference in the factor Accommodation ( $\mathrm{F} 3$ ) in quadrant Q3 and also in Additional infrastructure (F18), Respecting sustainable development of the destination (F19) and Certification of accommodation (F 2O) in quadrant Q4. While factors F 18 and F 2O, at a significance level of $0.1 \%$, are evaluated with a very low score, the differences between visitors and residents are significant. On average, visitors awarded the scale importance of the factor Certification of accommodation (F 2O) with 3.61 points and residents with 3.21 points. The same occurs with the factor Sustainable development (F19) - visitors rated it with 3.86 points and residents 3.43 points. Table 3 shows the differences in perceptions, where in general visitors rate more significantly than residents. The results show that the factors Natural attractiveness, Destination safety, Accessibility, and Quality and availability of information are important for both groups. Significant differences in the factors are cultural and social attractiveness, as well as accommodation, overcrowding, acceptance by locals, and social and experiential activities. Perceiving the importance of safety in the destination is most important for people aged 41-50, as well as its cleanliness.

\section{Discussion}

The research focuses on the differences in the perception of factors in a rura destination among visitors and residents. Based on the research question being confirmed, there are statistically significant differences in the perceptions of selected factors between the group of visitors and residents. According to our research results it is important to analyse visitors and residents separately even for destinations not yet suffering from over-tourism and irritation of local people. In most cases, visitors rate the factors higher on both axes (importance and performance) than residents. In addition, visitors may be more sensitive (Mok et al., 2001; Ryglová et al., 2017). Many aspects are ordinary for a resident, and after a while, they may stop perceiving them at all. However, knowledge of the aspects mentioned is very important, yet they create different perceptions (Stylidis et al., 2016). Hussain et al. (2019) pointed out that those residents who evaluate the environmental effects of tourism positively, give more noticeable support to tourism. Tourism can signify both positive and negative effects on environmental, socio-cultural and economic components for the locals. Puczko and Ratz (2000) append that although local people perceive some unfavourable impacts of tourism, they still support it. Considering the diverse impacts on the support of residents, Hussain et al. (2019) have found that perceived economic impact has the highest effect, after the socio-cultural and, lastly, the environmental effect. In this way, it is possible to increase visitors' satisfaction while not disturbing the lives of local inhabitants. When focusing on Q2 - Concentrate here, some perception differs more than in other quadrants. The factors Friendly acceptance by the locals (F10), Image of the destination (F11) and Overcrowding of the destination (F16) that belong to the second quadrant according to visitors, are linked with sustainable developments, which is a current topic (UNW TO, n.d.b).

One of the problems is mass tourism and overcrowding of a destination (Matulik, 2019). Nowadays, some tourist destinations are overcrowded and huge concentrations of visitors disrupt the lives of local people. Overcrowding is starting to be a hot topic of international tourism discussions. Furthermore, attitudes 
Table 3 Differences in Perception and Comparison between IPA and Statistical Testing

\begin{tabular}{|c|c|}
\hline $\begin{array}{l}\text { Differences in perception of factors } \\
\text { between visitors and residents }\end{array}$ & $\begin{array}{l}\text { Comparison of differences in perception of factors } \\
\text { between IPA and statistical testing }\end{array}$ \\
\hline $\begin{array}{l}\text { Destination cleanliness }(p=0.001) \text { and the overall image of } \\
\text { the destination }(p=0.05) \text { are more important for visitors. } \\
\text { Cultural and social attractions, Friendly acceptance by the } \\
\text { locals ( } p=0.05) \text { and Overcrowding of the destination ( } p \\
=0.001) \text { are perceived more significantly by visitors ( } p= \\
\text { o.05). } \\
\text { Certification of accommodation facilities ( } p=0.001) \text { and } \\
\text { Respecting sustainable development ( } p=0.001) \text { are not } \\
\text { paid much attention to, they are relatively scored overall, } \\
\text { however, visitors still give more points to these factors. } \\
\text { Residents emphasize more the uniqueness of the destina- } \\
\text { tion, but this difference is not statistically significant }(p> \\
\text { o.05). }\end{array}$ & $\begin{array}{l}\text { In the IPA analysis, there is a difference in the factor F } 8 \\
\text { Availability and quality of destination information. This } \\
\text { factor belongs, according to the residents, to Q1, for visitors } \\
\text { to Q2 (on the line Q2\&Q3). } \\
\text { Factors F9 Information and communication prior to ar- } \\
\text { rival (visitors on the line Q2\&Q3 and residents Q3) and F12 } \\
\text { Level of prices of services (visitors Q2 and residents Q4) } \\
\text { also differ in the IPA analysis. } \\
\text { There is a further difference in F5 Social and experimental } \\
\text { events (Q4 visitors and Q3 residents). } \\
\text { The aforementioned factors are not statistically signifi- } \\
\text { cantly different, but in IPA analysis these factors belong to } \\
\text { different quadrants. }\end{array}$ \\
\hline
\end{tabular}

of local people to visitors are not very welcoming in overcrowded destinations. Nevertheless, the perception of mass tourism varies according to the type of destination, while this factor is perceived more in urban destinations. It also depends on the country and location (Kuščer \& Mihalič, 2019; Rasoolimanesh et al., 2017). A high concentration of people can cause pressure on infrastructure, changes of lifestyle, disturbance of overall well-being, price increase on the property market, growth of crime, noise, riots, etc. (Kuščer \& Mihalič, 2019; Milano et al., 2018). Similarly, in research focused on the centre of Prague, visitors and residents agreed that mass tourism changes the historical centre of the city (Simpson, 1999). The regional tourism organizations should deal with this kind of problem (Puczko \& Ratzs, 200o). In rural destinations, this problem is not so critical, which is also highlighted by the outcome of the present research. The reasons for visiting a rural destination are different from those for an urban destination (GarcíaHernández et al., 2017 Namberger et al., 2019; Ryglová et al., 2017). Visitors mostly travel with their families or friends and stay there for more than a day - usually a weekend, i.e. about 2-3 days, sometimes longer. It can therefore be assumed that visitors are not as concentrated in one place as in city centres. On the other hand, overcrowding can have a negative impact on factors in quadrant Q1 where it can negatively af- fect nature, the cultural environment and others (Hall, 2019).

Price rises are also related to tourism and high demand (Milano et al., 2018). According to the research, visitors rate prices as a more important factor than the locals do. The reason may be that the locals of the Moravian Karst do not visit tourist attractions. Due to the great interest, these attractions are often more expensive. Another reason may be that visitors travel to the destination with children, and the one-off expenses may therefore increase. A visitor-oriented factor, Friendly acceptance (F10) by the locals, is also worth mentioning. It was expected that the difference between the two groups would be large and it has been proven that the visitors evaluated the factor of friendly acceptance by locals much more significantly. Understandably, it is more difficult for a resident to value the environment in which they live. On the other hand, this factor belongs to the more important ones, which creates overall perception and positive emotions of destinations (Ashworth \& Page, 2011). Besides this, overcrowding of a destination is connected with these factors - a massive crowd of tourists creates a negative perception of tourism, which afterwards leads to residents' unfriendly behaviour, and the perception of safety or danger in the destination. Overcrowding and friendly acceptance by the locals are factors that are closely related to the overall quality of destina- 
tion (Ashworth \& Page, 2011). According to the results, people stay longer and they return to the countryside often. This gradually builds loyalty to the place and to the service provider, who apparently could be a local inhabitant.

Sustainability is a relatively common topic nowadays and many authors talk about it (Boley et al., 2017; Hall, 2019; Hassan, 2000). Yet, respondents do not pay too much attention according to the factor Respecting sustainable development. As mentioned above, sustainability is connected to the most important factors, such as protection of natural and cultural heritage or cleanliness in the destination (Hall, 2019). Puczko and Ratz (2000) determined that due to the tourism's development characteristics in the region, only some form of mass tourism can be maintained. The cleanliness of the destination is also significant for the visitors. The results show that the most important factor is natural and cultural attractions. Rural tourism is a certain escape from the big city. Following this, research shows that untouched scenery and cleanliness in a destination are crucial for respondents and that people look for a clean and undisturbed landscape. On the other hand, sustainability in tourism helps avoid overloading the destination, and aids in maintaining its quality (Hall, 2019; Hassan, 2000).

Nevertheless, certain regions in the Czech Republic are not so frequently visited, thus this factor is irrelevant for both visitors and residents. And perhaps the missing information about tourism and its negative consequences might influence this as well. The factor Certification of accommodation and food (F 2O) can also be influenced by lack of information as the respondents do not consider this factor important, either. At the same time, there is growing pressure for quality and certification in the Czech Republic (Jakšová, 2018). Although some factors are located in the same quadrant of the IPA graph, some statistically significant differences between visitor and resident ratings and vice versa have been proved. It is, therefore, appropriate to carry out additional testing to correctly interpret the IPA results. The $t$-test was chosen for this research because they revealed significant differences in IPA that are not so obvious at first sight. Nevertheless, it would not be necessary if two groups are not compared with each other. The advantage of this method is its simplicity and quick feasibility. When comparing multiple variables, it would make sense to also use MANOVA or ANOVA analysis.

\section{Conclusion}

The research aims to propose measures that will support the development of destination quality around the differences between the aforementioned groups. Based on individual IPA analyses, it can be stated that the most significant difference in perception lies in quadrant Q2 - Concentrate here. It is necessary to pay particular attention to the factor Overcrowding of the destination, as it may negatively affect other aspects of the destination. At the same time, there is little awareness of the linkages of sustainable tourism and the quality of services. It is, therefore, necessary to involve destination organizations and create a link between service providers and potential customers. Nonetheless, the local population should not be forgotten, as the attitude of the locals can determine the overall perception of the destination, and their attitude to tourism is directly related to overall visitors' satisfaction.

Considering the previous, we can conclude that there is space just for destination organizations, which could take a certain responsibility for quality and awareness (Dania et al., 2019; Go \& Govers, 2000). According to the research, destination management should analyse visitors and residents separately. If only the IPA analysis is used, the factors seem to be similar. Adding the $t$-test, it is shown that the differences are significant. Since tourism is a dynamically developing industry and visitors constantly increase their demands, it is, therefore, necessary to further create and maintain the attractiveness of the destination. It is necessary to proceed comprehensively and develop all the essential parameters of tourism (accommodation, catering, transport accessibility, cleanliness, etc.). Destination management should evolve tourism according to the principles of sustainable development and protect the negative impact of tourism on the environment as well as a negative impact on local people and on their cultural identity. Primarily, it is important to focus on the factors in quadrant $\mathrm{Q} 2$ because they can 
have both negative and positive effects on all other quadrants. Regarding this, it would be advisable to focus on tourism sustainability. Moreover, there should be a permanent dialogue between destination organizations, city authorities and local people. Speaking of sustainability, it is important to maintain the integrity of parks, the local economy and public transport (Milano et al., 2018). Nowadays, it is also possible to consider the involvement of smart technologies as it can facilitate communication with stakeholders as well as help maintain dialogue and education (Wang et al., 2016).

The present research was followed by an equal number of visitors (50.3\% of the total sample) and residents ( $49,7 \%$ of the total sample). Based on this it was possible to compare the perception of factors between visitors and residents. Regarding this, there should be some limits. It can be expected that people interested in this issue were more likely to participate in the research and their positive interest may subsequently cause a slight overestimation of the results. It is also advisable to point out the results of IPA analysis itself. Although the development of two separate IPA analyses has brought some new information, the results need to be treated with caution and analysed statistically as the individual analysis points out a higher difference. Only then can one claim that there is indeed a difference in perception. However, how apparent this difference is under real conditions is difficult to evaluate.

For any future research, it is advisable to conduct a similar survey in another rural destination and compare it with our results. At the moment, the results of the present study cannot be generalized. Moreover, it may be very difficult for respondents to evaluate the importance and performance at the same time, posing yet another potential limitation.

\section{References}

Ashworth, G., \& Page, S. J. (2011). Urban tourism research: Recent progress and current paradoxes. Tourism Management, 32(1), 1-15.

Ayikoru, M. (2015). Destination competitiveness challenges:

A Ugandan perspective. Tourism Management, 50, 142158.

Azzopardi, E., \& Nash, R. (2013). A critical evaluation of importance-performance analysis. Tourism Management, $35,222-233$.

Barrado, T. (2004). El concepto de destino turístico: Una aproximación geográfico-territorial. Estudios turísticos, 160, 45-68.

Bi, J. W., Liu, Y., Fan, Z. P., \& Zhang, J. (2019). Wisdom of crowds: Conducting importance-performance analysis (IPA) through online reviews. Tourism Management, 70 , $460-478$.

Bieger, T., \& Beritelli, P. (2012). Management von Destinationen. München Oldenbourg Verlag.

Boley, B. B., McGehee, N. G., \& Hammett, A. T. (2017). Importance-performance analysis (IPA) of sustainable tourism initiatives: The resident perspective. Tourism Management, 58, 66-77.

Buhalis, D. (2003). eTourism: Information technology for strategic tourism management. Pearson Education.

Caber, M., Albayrak, T., \& Matzler, K. (2012). Classification of the destination attributes in the content of competitiveness (by revised importance-performance analysis). Journal of Vacation Marketing, 18(1), 43-56.

Caruana, A., Pitt, L., \& Berthon, P. (1999). Excellence-market orientation link: Some consequences for service firms. Journal of Business Research, 44(1), 5-15.

Centrála cestovního ruchu - Jižní Morava. (2019). Marketingová strategie Jiřní Moravy: 2018-2020. https://www .ccrjm.cz/wp-content/uploads/2019/11/Marketingov $\% \mathrm{C}_{3} \% \mathrm{~A} 1$-strategie-Ji\%C5\%BEn\%C3\%AD-Moravy-2018 -2020.pdf

Dania, T., Mlejnková, K., \& Rašovská, I. (2019). Quality destination management. Acta Universitatis Agriculturae et Silviculturae Mendelianae Brunensis, 67(4), 1027-1037.

Dortyol, I. T., Varinli, I., \& Kitapci, O. (2014). How do international tourists perceive hotel quality? An exploratory study of service quality in Antalya tourism region. International Journal of Contemporary Hospitality Management, 26(3), 470-495.

Dwyer, L., Dragićević, V., Armenski, T., Mihalič, T., \& Knežević Cvelbar, L. (2016). Achieving destination competitiveness: An importance-performance analysis of Serbia. Current Issues in Tourism, 19(13), 1309-1336.

Ekolist. (2018, March 6). Návštěvnost jeskyní v Moravském krasu se loni zvýšila. Ekolist.cz. https://ekolist.cz/cz/ zpravodajstvi/zpravy/navstevnost-jeskyni-v-moravskem -krasu-se-loni-zvysila

Ennew, C. T., Reed, G. V., \& Binks, M. R. (1993). Importanceperformance analysis and the measurement of service quality. European Journal of Marketing, 27(2), 59-70.

European Commission. (2003). A manual for evaluating the 
quality performance of tourist destinations and services (Enterprise DG Publication). Office for Official Publications of the European Communities. https://ec.europa .eu/growth/content/manual-evaluating-quality -performance-tourist-destinations-and-services-o_en

García-Hernández, M., la Calle-Vaquero, D., \& Yubero, C. (2017). Cultural heritage and urban tourism: Historic city centres under pressure. Sustainability, 9(8), 1346. https://doi.org/10.3390/su9o81346

Go, F. M., \& Govers, R. (200o). Integrated quality management for tourist destinations: A European perspective on achieving competitiveness. Tourism Management, 21(1), 79-88.

Goeldner, C. R., \& Ritchie, J. R. B. (2014). Cestovní ruch: principy, př́klady, trendy. BizBooks.

Hall, C. M. (2019). Constructing sustainable tourism development: The 2030 agenda and the managerial ecology of sustainable tourism. Journal of Sustainable Tourism, 27(7), 1044-106o.

Hassan, S. S. (200o). Determinants of market competitiveness in an environmentally sustainable tourism industry. Journal of Travel Research, 38(3), 239-245.

Herrera, M. R. G., Sasidharan, V., Hernández, J. A. Á., \& Herrera, L. D. A. (2018). Quality and sustainability of tourism development in Copper Canyon, Mexico: Perceptions of community stakeholders and visitors. Tourism Management Perspectives, 27, 91-103.

Hudson, S. (2008). Tourism and hospitality marketing: A global perspective. Sage.

Hussain, K., Ali, F., Nair, P. K., Ragavan, N. A., \& Nair, V. (2019). Perceived impacts and residents' support for tourism development in Port Dickson, Malaysia. Turizam: medunarodni znanstveno-stručni časopis, 67(4), 351-364.

Jakšová, B. (2018). Destinační management v České republice: nový systém kategorizace a certifikace [Unublished diploma thesis]. Vysoká škola ekonomická v Praze.

Johns, N. (2001). Importance-performance analysis using the profile accumulation technique. Service Industries Journal, 21(3), 49-63.

Kim, T. K. (2015). T test as a parametric statistic. Korean Journal of Anesthesiology, 68(6), 540-546.

Kotler, P., \& Keller, K. L. (2007). Marketing management. Grada Publishing.

Kuščer, K., \& Mihalič, T. (2019). Residents' attitudes towards overtourism from the perspective of tourism impacts and cooperation - The case of Ljubljana. Sustainability, 11(6), 1823. https://doi.org/10.339o/su11061823

Lai, I. K. W., \& Hitchcock, M. (2015). Importance-perfor- mance analysis in tourism: A framework for researchers. Tourism Management, 48(C), 242-267.

Levenburg, N. M., \& Magal, S. R. (2004). Applying importance-performance analysis to evaluate e-business strategies among small firms. E-Service, 3(3), 29-48.

Martilla, J. A., \& James, J. C. (1977). Importance-performance analysis. Journal of Marketing, 41(1), 77-79.

Matulik, R. (2019, July 24). Masový a nezvládnutý turismus devastuje populární destinace. Český rozhlas. https://plus .rozhlas.cz/masovy-a-nezvladnuty-turismus-devastujepopularni-destinace-staci-jet-jinam-8039752

Matzler, K., Sauerwein, E., \& Heischmidt, K. (2003). Importance-performance analysis revisited: The role of the factor structure of customer satisfaction. The Service Industries Journal, 23(2), 112-129.

Middleton, V. T. C., \& Clarke, J. (2001). Marketing in travel and tourism. Butterworth-Heinemann.

Milano, C., Cheer, J. M., \& Novelli, M. (2018, July 18). Overtourism: A growing global problem. The Conversation. https://theconversation.com/overtourism-a-growing -global-problem-100029

Milošević, S., Penezić, N., Mišković, I., Škrbić, I., \& Katić, I. (2016). The significance of tourists' satisfaction at the destinations. In 23rd Biennial International Congress, Tourism \& Hospitality Industry 2016 (THI2016), Trends and Challenges, Opatija, Croatia, 28-29 April 2016 (pp. 219-231). University of Rijeka.

Mok, C., Sparks, B., \& Kadampully, J. (2013). Service quality management in hospitality, tourism, and leisure. Routledge.

Namberger, P., Jackisch, S., Schmude, J., \& Karl, M. (2019). Overcrowding, overtourism and local level disturbance: How much can Munich handle? Tourism Planning \& Development, 16(4), 452-472.

Oh, H. (2001). Revisiting importance-performance analysis. Tourism Management, 22(6), 617-627.

Pásková, M. (2009). Udržitelnost rozvoje cestovního ruchu. Gaudeamus Univerzita Hradec Králové.

Politis, Y., Litos, C., Grigoroudis, E., \& Moustakis, V. S. (2009). A business excellence model for the hotel sector: Implementation to high/class Greek hotels. Benchmarking: An International Journal, 16(4), 462-483.

Puczko, L., \& Ratz, T. (200o). Tourist and resident perceptions of the physical impacts of tourism at Lake Balaton, Hungary: Issues for sustainable tourism management. Journal of Sustainable Tourism, 8(6), 458-478.

Ramakrishnan, R., \& Usha, R. (2016). A new rational IPA and application to cruise tourism. Annals of Tourism Research, 61(C), 264-267. 
Rasoolimanesh, S. M., Roldán, J. L., Jaafar, M., \& Ramayah, T. (2017). Factors influencing residents' perceptions toward tourism development: Differences across rural and urban world heritage sites. Journal of Travel Research, 56(6), 760-775.

Rašovská, I., Kubíčková, M., \& Ryglová, K. (2020). Importance-performance analysis approach to destination management. Tourism Economics. https://doi.org/10 $.1177 / 1354816620903913$

Ryglová, K., Rašovská, I., \& Šácha, J. (2017). Rural tourism: Evaluating the quality of destination. European Countryside, 9(4), 769-788.

Ryglová, K., Vajcnerová, I., Sácha, J., \& Stojarova, S. (2015). The quality as a competitive factor of the destination. Procedia: Economics and Finance, 34, 550-556.

Sampson, S. E., \& Showalter, M. J. (1999). The performanceimportance response function: Observations and implications. Service Industries Journal, 19(3), 1-25.

Simpson, F. (1999). Tourist impact in the historic centre of Prague: Resident and visitor perceptions of the historic built environment. Geographical Journal, 165(2), 173-183.

Stylidis, D., Sit, J., \& Biran, A. (2016). An exploratory study of residents' perception of place image: The case of Kavala. Journal of Travel Research, 55(5), 659-674.

Su, L., Swanson, S. R., \& Chen, X. (2016). The effects of perceived service quality on repurchase intentions and subjective well-being of Chinese tourists. Tourism Management, 52, 82-95.

Tonge, J., \& Moore, S. A. (2007). Importance-satisfaction analysis for marine-park hinterlands: A Western Australian case study. Tourism Management, 28(3), 768-776.

Unw To. (N.d.a). About us. https://www.unwto.org/about -us

UN w To. (N.d.b). Sustainable development. https://www .unwto.org/sustainable-development

Wang, X., Li, X. R., Zhen, F., \& Zhang, J. (2016). How smart is your tourist attraction? Measuring tourist preferences of smart tourism attractions via a FCEM-AHP and IPA approach. Tourism Management, 54, 309-320.

Weaver, P. A., Weber, K., \& McCleary, K. W. (2007). Destination evaluation: The role of previous travel experience and trip characteristics. Journal of Travel Research, 45(3), 333-344.

Wong, M., Hideki, N., \& George, P. (2011). The use of importance-performance analysis (IPA) in evaluating Japan's egovernment services. Journal of Theoretical and Applied Electronic Commerce Research, 6(2), 17-30.

Zelenka, J., \& Pásková, M. (2012). Výkladový slovník cestovního ruchu. Linde Praha.

\section{Appendix}

The following factors were researched:

1. Natural attractions (the conditions of natural character - for instance, climate, hydrological and morphological circumstances, flora, fauna, water surfaces, caves, natural reservations).

2. Cultural and social attractions (for instance, castles, chateaus, galleries, museums, technical sights, religious monuments, historical city centres).

3. Accommodation (variety, structure, and level of accommodation facilities).

4. Food (variety, structure, and level of boarding facilities).

5. Social and experiential events (for example, concerts, festivals, folk, sports and other events, local markets, seasonal gastronomical events such as wine harvests).

6. Availability of transportation to the destination (the accessibility of the destination, transport infrastructure, the frequency of transport links, distances between stops).

7. Local transportation (the possibilities of motorized and non-motorized transport around the destination, the conditions and equipment of the means of transport, the frequency and distances of stops from attractions, taxis, ski lifts, cableways and so on).

8. Availability and quality of the information in the destination (tourist information centres, maps, promotional materials, orientation boards, internet - Wi$\mathrm{Fi})$.

9. Information and communication prior to arrival (the promotion and distribution of the destination offer, available and user-friendly unified web portal with topical destination offer that enables online reservations, links to related websites, information on social networks and so on).

10. Friendly acceptance by the locals (atmosphere at the destination, friendly relationships with visitors).

11. Image of the destination.

12. Level of prices of services and goods at the destination (the prices of consumer goods and services at the destination).

13. Level of personnel quality in tourism services - which means in accommodation and boarding services, information centres, transportation, guides and so on (their professionalism, empathy, willingness, reliability, credibility, opening hours, the effort to meet individual requirements of a client).

14. Sense of security (crime, terrorism, natural disasters, diseases, rescue and health system, the security 
of sights, the security of pedestrians or cyclists, safe background/attractions for children).

15. Destination cleanliness (natural environment, air, water for swimming, public toilets, enough waste bins, the cleanliness and maintenance of sights, the cleanliness of hospitality facilities).

16. Overcrowding of the destination (high concentration of visitors decreasing the quality of their stay, the capacity congestion of infrastructure, for example, car parks).

17. The uniqueness of the destination (the uniqueness of the destination, local products, the differentiation of competitive offers, pre-prepared service packets, products of the destination for various target segments, service certification).
18. Additional infrastructure (for example, sports equipment rental shops, cycle paths, cross country ski trails, hippo trails, aqua parks, playgrounds, entertainment centres, climbing centres, cash dispensers, background for motorists, cyclists, children).

19. Respecting sustainable development of the destination (the concordance of infrastructure construction with the natural environment of the destination, cultural heritage protection - for instance, protection of historical buildings, folklore and regional cuisine, natural environment protection, ecological economy, local inhabitants and business involvement).

20. Certification of accommodation and food services. 



\title{
Willingness to Pay More: The Quest for Superstar Museums
}

\author{
Nuria Recuero Virto \\ Universidad Complutense de Madrid, Spain \\ nrecuero@ucm.es \\ María Francisca Blasco López \\ Universidad Complutense de Madrid, Spain \\ fblasco@ucm.es \\ Juan Antonio Mondejar \\ Universidad Castilla-La Mancha, Spain \\ juanantonio.mondejar@uclm.es
}

Museum managers constantly focus their efforts on gaining economic viability. This has become a key challenge as the offer of 'experience economy' attractions is increasingly rising and visitors are searching for experiences that are competitive. Although it has been stated that a picture paints a thousand words, the main objective of this research is determining if the relationship between museum image and visitors' satisfaction significantly and positively influences their willingness to pay more. Partial least analysis was used to conduct the multi-group comparison by including the recently developed measurement invariance of composites (м гсом) and new permutation methods. A total of 529 valid responses of museum visitors were obtained. Interestingly, the findings showed that there were no significant differences between the two museum samples, and that all the relationships analysed were positive and significant. Interestingly, Henseler's MG A identified a slight difference between the two museum visitor samples in the linkage between visitors' satisfaction and visitors' word of mouth. This research proposes a multi-group comparison study examining two different samples of visitors to two superstar Mexican museums so that findings provide useful generalizations that imply academic and managerial contributions for the tourism industry.

Keywords: multi-group, satisfaction, image, willingness to pay more, word of mouth

(cc)BY-SA https://doi.org/10.26493/2335-4194.14.101-114

A museum's function is not only to operate as an economic development engine but also as a destination icon (Carey et al., 2012; Moreno-Gil \& Ritchie, 2009; Sheng \& Lo, 2010; Vu et al., 2018). In this context, museum managers are constantly focusing their efforts on maintaining and raising visitor numbers by fostering their satisfaction in a gradually more saturated 'experience economy' marketplace (Evrard \& Krebs, 2017;
Harrison \& Shaw, 2004; Han \& Hyun, 2017; McLean, 1994; Ober-Heilig et al., 2014). Meanwhile, governments are expecting that certain places increase visitor numbers, so these gain economic viability, and visitors are demanding experiences that are 'value for money' (Ferrari et al., 2018; Gázquez-Abad et al., 2014; Mondéjar-Jimenez et al., 2010; Pop \& Borza, 2016; Recuero et al., 2017). 
The importance of word of mouth (шом) advocacy has been acknowledged, as it is one of the key reasons for museum visiting (Hausmann, 2012). wo M is considered one of the most effective tourism communication channels as those customers that spread the word among their family and friends are far more credible and trustworthy than market-oriented strategies (Confente, 2015; Wang et al., 2017). Likewise, museum pricing has generated substantial attention among many scholars as entry profits have always been considered a fundamental source of income (e.g. Rentschler et al., 2007; Sharifi-Tehrani et al., 2013; Steiner, 1997; Frey \& Steiner, 2012).

Throsby and Withers (1979), in the context of the arts, introduced willingness to pay (W T P) and contingent valuation ( $\mathrm{CVM}$ ) concepts, with some particularities regarding people's willingness to pay (Kim et al., 2010). The intrinsic value of art implies that people may lack the level of information required to make a decision, and have difficulties in measuring it quantitatively (Throsby, 2003). Due to this situation, other scholars have suggested choice modelling to approach museum pricing strategies as this methodology takes into account the attractiveness of the features' characteristics (e.g. Burton et al., 2009; Choi et al., 2010). Although scholars have analysed w TP in museums (e.g. Plaza, 2010; Tohmo, 2004), scant literature has been found that analyses the impact of satisfaction on willingness to pay more (WPM) in the museum context (Bigné et al., 2008).

Tourism scholars have described image as a combination of perceptions, impressions and feelings, which in essence comprises cognitive - pondering beliefs - and affective - feelings - components (Chi \& Qu, 2008; Min et al., 2013; Moreno-Gil \& Ritchie, 2009; Stylos et al., 2016; Whang et al., 2016; Wu, 2015). In this regard, no research has been found that analyses museum image effect on satisfaction.

This study aims to determine the positive and significant relationship between museum satisfaction on WOM and WPM, and between museum image and satisfaction. The research setting has been the Frida Kahlo and Anahuacalli museums. As far as we know, this is the first attempt to employ partial least multigroup analysis to test the aforementioned relation- ships. The objective is important because museumgoers' behavioural outcomes research is scarce and is in need of empirically verified generalizations.

\section{Theoretical Framework}

\section{Museum Satisfaction as a Driver of WOM}

and Willingness to Pay More

Since the beginning of the decade, museums have become market-oriented; focusing ever more on the needs of their visitors as these provide an income source that enhances the social and economic welfare of local communities (Moreno-Gil \& Ritchie, 2009; Stylianou-Lambert, 2011; Yamada \& Fu, 2012). In the tourism paradigm, satisfaction is commonly employed as a critical ratio for the assessment of the cognitive and affective elements of travel experiences (Camarero \& Garrido, 2011; Han \& Hyun, 2017; Mason \& Paggiaro, 2012; Wang \& Wu, 2011) that visitors always associate against their expectations (Agyeiwaah et al., 2016) to generate a subjective reference framework that helps them create comparative judgments (Campón-Cerro et al., 2017).

Museum visitors demand participation, learning options, and enjoyment from the museum experience (Del Chiappa et al., 2013; McIntyre, 2009; Trinh \& Ryan, 2013; Yamada \& Fu, 2012). Museumgoers, to evaluate their perceived overall performance, take into account the functional features the tourist resource offers - staff attention, facilities and convenience - and the affective components - emotional, epistemic and social elements (Bigné et al., 2008; Del Chiappa et al., 2014). Hence, it is reasonable that satisfaction has been considered a key predictor of consumers' behaviour (Kuikka \& Laukkanen, 2012) and, consequently, an imperative requisite for long-term museum success (Brida et al., 2016; Kim et al., 2012).

Scholars have suggested as reasons for the appearance of a positive Wом intention altruistic motives the aspiration to help others, instrumental motivations - the need to show wisdom, and cognitive dissonance reduction purposes - reaffirming themselves and others about the service selection (Simpson \& Siguaw, 2008). In the case of museums, this advocacy has been referred to as a crucial promotional tool that merges as a post-purchase behaviour (Harrison \& Shaw, 2004). 
In this respect, since the early 9os it has been noted that to achieve a positive wом, museum managers must initially ensure visitors' satisfaction (e.g. DiMaggio, 1985; McLean, 1994; Hume et al., 2007; Brida et al., 2016). This type of communication has a significant role in the museum industry as visitors normally share their opinions online and offline (Hausmann, 2012).

Scholars have emphasized that visitors unconsciously generate positive and negative behavioural outcomes after a tourism service experience (Tian-Cole et al., 2002; Tsai \& Wang, 2017), and that those visitors that feel satisfied are normally predisposed to recommend the place and pay more (Cevdet \& Erkut, 2015). As discussed above, it has been suggested that museum satisfaction might be a driver of the museum wо . This linkage has been widely proved to be positive and significant in different services industries (e.g. Babin et al., 2005; Ladhari et al., 2008) and more precisely in tourism (Simpson \& Siguaw, 2008; Kim et al., 2009; Prebensen et al., 2010). In the study context, Harrison and Shaw (2004) found a positive relationship between these two dimensions in a small metropolitan museum in Australia. Also, Camarero and Garrido (2011) proved this relationship to be positive and significant in a research conducted in Patio Herreriano Contemporary Spanish Art Museum with 133 valid answers. However, Trinh and Ryan (2013) could not support that highly satisfied visitors tend to recommend a specific museum to others in a research conducted in the Cham Museum of Vietnam. Despite this controversy, it seems rational to expect that visitors that feel satisfied will have the behavioural outcome of spreading the word among their friends and relatives.

Although W PM has been recognized as a significant matter in museums, and in tourism services in general, limited studies have analysed the drivers of this behavioural attitude (Ladhari et al., 2008). Tourism scholars have concluded that satisfaction has a positive and significant effect on WPM. In this regard, several researchers have proved this linkage to be positive and significant in the hotel industry (Barsky \& Nash, 2002; Lee et al., 2010; Lin, 2016) and in restaurants (Ladhari et al., 2008; Heung \& Gu, 2012). In ad- dition, it has been found that this relationship has only been studied once in the museum industry. Bigné et al. (2005) found this linkage insignificant in a theme park, but Bigné et al. (2008) revealed that satisfaction has a positive and significant effect on W PM in a museum context, while it was again found to be negative in the theme park setting. It seems likely that if museumgoers are satisfied they will likely be predisposed to pay more. Based on the previous discussion, the following hypotheses were developed.

$\mathrm{H} 1$ Museum satisfaction has a positive and significant effect on (a) museum Wом and (b) WPM.

\section{Museum Image Impact on Satisfaction}

Museum image has been considered as a perceptual phenomenon difficult to define as it is determined by subjectivity, and both aspects, cognitive and affective, provide a global image of the tourism service (Beerli \& Martín-Santana, 2004; Martínez \& Pina, 2009; Wu, 2016). However, in tourism literature, there is an absence of a universal definition or an accepted scale to define image, due to lack of homogeneity of the attributes that define this concept (Beerli \& MartínSantana, 2004). Additionally, it has been asserted that image has been affected with the proliferation of online information (Molinillo et al., 2018), which has denoted the relevance of adequate management of this dimension. In addition, it has been stated that heritage has been used in cultural tourism to promote positive images of a place or site (Secondi et al., 2011).

Museum image has also been considered as a component of brand personality (Liu et al., 2013). Scant literature has extensively analysed the dynamics of museum image. In reference to residents' perceptions, several researchers concluded that residents normally generate positive images concerning the local museum (Rosenberg et al., 1960; Vaughan, 2001). Also analysed have been visitors' impressions showing that foreign visitors were influenced by the destination images of Hawaii and expected a learning experience of Native Hawaiian culture from the museum visit (Harrison, 1997). In addition, Moreno-Gil and Ritchie (2009) examined the image formation process from both perspectives. They pointed out that overall image has a positive effect on satisfaction in both cases. 
Incidentally, it has been indicated that a positive preconceived image of a place has a favourable impact on the individual's expectations of the upcoming experience (Chi \& Qu, 2008; del Bosque \& San Martin, 2008). It has been specified that image is a relevant indicator of satisfaction (Leung et al., 2011), which has been supported by numerous tourism studies that have examined this effect (Assaker et al., 2011; Chi \& $\mathrm{Qu}$, 2008; Loi et al., 2017; Prayag, 2009; Wang \& Hsu, 2010). In general, past findings have proved that image is a direct antecedent of satisfaction.

$\mathrm{H} 2$ Museum image has a positive and significant effect on museum satisfaction.

\section{Methodology}

\section{Data Collection Procedure and Sample Profile}

The study was conducted in the Frida Kahlo and Anahuacalli museums. The Frida Kahlo museum can be considered a superstar museum due to the Mexican cultural icon, whereas Anahuacalli is a more modest and traditional museum. The management of both museums is assigned to the same team. Since a high response rate was desired, and the research involved a population that visits the museums, the personal survey method was selected (Lee, 2013; Xu \& Fox, 2014). Trained interviewers gathered data outside the museums from those visitors that had already visited them, either in English or Spanish depending on the origin of participants, from the 18th of March to the 16 th of June 2016. Several precautions were taken to reduce common method variance (смv), following Podsakoff et al.s (2003) recommendations. For instance, to minimize evaluation apprehension, respondents were informed about the purpose of the study and were assured confidentiality and anonymity. In addition, to avoid field researchers' selection bias, the interviewers were instructed to look for a similar portion of male and female participants in various age groups (Kim et al., 2006).

$\mathrm{G}^{\star}$ Power 3 was used to perform power analysis (Faul et al., 2007) and both sample sizes guaranteed power for the $R^{2}$ deviation from zero test as the results in both cases were above 95 per cent for the model proposed in Figure 1 (Cohen, 1988). Therefore, the

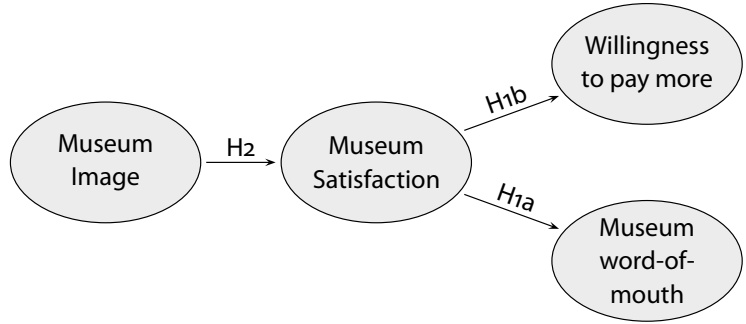

Figure 1 Theoretical Model and Hypotheses

statistical power of 325 and 204 for the two groups examined in this research are acceptable sample sizes. In addition, Harman's single-factor test was conducted to check CMV (Podsakoff et al., 2003) using principal components without rotation in SPPS, and the analysis returned that a single factor explained 36.8 per cent of the variance in the Frida Museum sample case and 48.7 per cent of variance in Anahuacalli Museum sample, which implies a low level of common method bias in the research design.

Convenience sampling was used as it permits reaching a substantial number of respondents that are willing to participate in the study, and saves costs and time in collecting data (Sinclair-Maragh, 2017). Of the 345 Frida Kahlo visitors and 216 Anahuacalli visitors that were invited to participate, 325 and 204, respectively, provided usable questionnaires for the research. The rate of response of 94 per cent in both cases $(325 / 345$ and 204/216) points out that sample bias would not be an issue (Fowler, 1984; Yuksel et al., 2010). Respondents were mainly national, female, aged from 26 to 35 and undergraduates or graduates that have only visited the museums once (Table 1). Table 2 shows the measurement model and the descriptive analysis. In brief, the mean values indicate that Frida Kahlo Museum visitors value slightly better all the dimensions of the proposed model than Anahuacalli Museum visitors. In addition, willingness to pay more seems to be the least valued factors in both samples.

\section{Measurement Model}

A seven-point Likert scale measured all items. $\mathrm{Mu}$ seum image was adapted from $\mathrm{Wu}$ (2015). Four items from the scale developed by Kuikka and Laukkanen (2012) were used to operationalize museum satisfac- 
Table 1 Sample Profile

\begin{tabular}{|c|c|c|c|c|c|}
\hline \multicolumn{2}{|c|}{ Characteristics } & \multicolumn{2}{|c|}{ Frequency } & \multicolumn{2}{|c|}{ Percentage } \\
\hline & & (1) & (2) & (1) & (2) \\
\hline \multirow[t]{2}{*}{ Gender } & Female & 203 & 117 & 62.5 & 57.4 \\
\hline & Male & 122 & 87 & 37.5 & 42.6 \\
\hline \multirow[t]{7}{*}{ Age } & $<17$ & 26 & 24 & 8.0 & $13 \cdot 3$ \\
\hline & $18-25$ & 83 & 63 & 25.5 & 34.8 \\
\hline & $26-35$ & 126 & 77 & 38.8 & 42.5 \\
\hline & $36-45$ & 51 & 22 & 15.7 & 12.2 \\
\hline & $46-55$ & 21 & 10 & 6.5 & 5.5 \\
\hline & $56-65$ & 12 & 6 & $3 \cdot 7$ & $3 \cdot 3$ \\
\hline & $>66$ & 6 & 2 & 1.8 & 1.7 \\
\hline \multirow[t]{4}{*}{ Education } & Postgraduate & 79 & 48 & $24 \cdot 3$ & 23.8 \\
\hline & Undergrad./grad. & 194 & 125 & 59.7 & 61.9 \\
\hline & Secondary & 49 & 29 & 15.1 & 14.4 \\
\hline & Primary & 3 & 2 & 0.9 & \\
\hline \multirow{4}{*}{$\begin{array}{l}\text { No. of } \\
\text { times } \\
\text { visited }\end{array}$} & 1 & 256 & 168 & 78.8 & 82.4 \\
\hline & $2-4$ & 58 & 29 & 17.8 & 14.2 \\
\hline & $5-8$ & 6 & 5 & 1.8 & 2.5 \\
\hline & $>9$ & 5 & 2 & 1.5 & 1.0 \\
\hline \multirow[t]{6}{*}{ Origin } & Asia & 6 & 1 & 1.8 & 0.5 \\
\hline & Europe & 26 & 15 & 8.0 & $7 \cdot 4$ \\
\hline & Latinoamerica & 50 & 40 & 15.4 & 19.6 \\
\hline & National & 161 & 130 & 49.5 & 63.7 \\
\hline & Oceania & 4 & 4 & 1.2 & 2.0 \\
\hline & USA & 78 & 14 & 24.0 & 6.9 \\
\hline
\end{tabular}

Notes Column headings are as follows: (1) Frida Kahlo Museum, (2) Anahuacalli Museum.

tion. Museum wом was captured using SirakayaTurk et al's (2015) scale. Willingness to pay more was measured using Bigné et al.s (2008) scale.

\section{Data Analysis}

Smartpls (version 3.2.7; Ringle et al., 2015) was employed to accomplish the Partial Least Squares Structural Equation Modelling (PLS-SEM) and multi-group (MGA) analyses, as this nonparametric SEM method is very suitable for MGA (Hair et al., 2014; Henseler et al., 2016; Sarstedt et al., 2011). Also, PLS-SEM has a minimum requirement concerning sample size as this tech- nique is based in oLs regressions and it is less severe when it operationalizes with non-normal data (Hair et al., 2014).

\section{Results}

\section{Assessment of the Measurement Model}

and Invariance Measurement Across Groups

Table 3 presents the results of the measurement model reliability and convergent validity test for both samples. All loading factors were above 0.7 , except for three (MI3, MW 2 and MW4). MI3 was dropped and MW 2 and MW 4 were retained as the cronbach alpha and AVE values were not altered, ensuing from Hair et al.s (2014) recommendations. The internal consistency of the study was determined through construct reliability, where the cronbach's alpha coefficients were higher than o.6o. Composite reliability coefficients were higher than the recommended value of 0.60 , specifying the shared variance among a set of observed items measured qpazimeasuring each construct (Fornell \& Larcker, 1981). The examination of convergent validity and discriminant validity confirms the validity of the results (Hair et al., 2011). Consistently, convergent validity was proved, as the average variance extracted (AVE) coefficient for each construct was above 0.50 (Fornell \& Larcker, 1981).

In addition, discriminant validity was confirmed by examining the shared variance between pairs of constructs and verifying it is lower than the corresponding AVE (Fornell \& Larcker, 1981), which determined the extent to which each construct differs from other latent variables in the measurement model (Hair et al., 2016) (Tables 4 and 5). In addition, the heterotrait-monotrait (нтмт) ratio method was implemented (Henseler et al., 2015) and all values were lower than 0.90 (Teo et al., 2008).

The acceptability of measurements models and measurement invariance were verified before examining MGA (Hair et al., 2016; Henseler et al., 2016; Rasoolimanesh et al., 2016; Rasoolimanesh et al., 2017; Sarstedt et al., 2011). The measurement invariance of composites (МІсом) assesses the measurement invariance so as to compare and deduce MGA's groupspecific differences of PLS-SEM results (Henseler et al., 2016). The evaluation of місом entails three steps: 
Table 2 Descriptive Analysis

Construct/Associated Items

$\frac{\text { Frida Kahlo }}{(1) \quad(2)} \frac{\text { Anahuacalli }}{(1) \quad(2)}$

Museum image (MI)

1. The Frida Kahlo Museum/The Anahuacalli Museum has something special

2. The Frida Kahlo Museum/The Anahuacalli Museum has a unique identity

$\begin{array}{llll}6.655 & 0.696 & 6.276 & 1.188\end{array}$

3. The Frida Kahlo Museum/The Anahuacalli Museum is very famous.*

$\begin{array}{llll}6.702 & 0.688 & 6.426 & 1.075\end{array}$

4. The Frida Kahlo Museum/The Anahuacalli Museum is attractive

$\begin{array}{llll}6.098 & 1.335 & 4.397 & 1.747\end{array}$

Museum satisfaction (MS)

1. I am pleased with the service received from the museum's employees

$\begin{array}{llll}6.582 & 0.734 & 6.167 & 1.168\end{array}$

2. I am happy with the panels, installations and the atmosphere created for the museum visit

3. I am content with the educational experience received in the visit to this museum

$\begin{array}{llll}6.305 & 1.188 & 6.152 & 1.257\end{array}$

$\begin{array}{llll}6.440 & 0.970 & 6.212 & 1.153\end{array}$

4. Overall, I am satisfied with this museum

$\begin{array}{llll}6.176 & 1.240 & 5.922 & 1.311\end{array}$

Museum wom (MW)

1. I will mention The Frida Kahlo Museum/The Anahuacalli Museum as a tourist attraction of Mexico City to others quite frequently

2. I will tell more people to visit The Frida Kahlo Museum/The Anahuacalli Museum before other tourist attractions of Mexico City

3. I will seldom miss an opportunity to tell others about The Frida Kahlo Museum/The Anahuacalli Museum

4. When I tell others about The Frida Kahlo Museum/The Anahuacalli Museum, I will also talk about the city in detail

$\begin{array}{llll}6.563 & 0.765 & 6.304 & 1.182\end{array}$

$\begin{array}{llll}6.695 & 0.778 & 6.279 & 1.195\end{array}$

$\begin{array}{llll}5.938 & 1.294 & 5.819 & 1.369\end{array}$

$\begin{array}{llll}6.131 & 1.300 \quad 5.936 & 1.473\end{array}$

$\begin{array}{llll}6.071 & 1.245 & 5.730 & 1.351\end{array}$

. I am proud to tell others that I visited The Frida Kahlo Museum/The Anahuacalli Museum

Willingness to pay more (WPM)

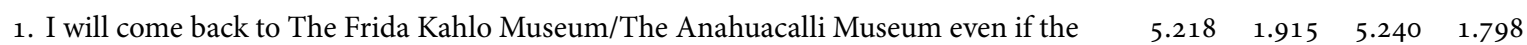
entrance fee increases

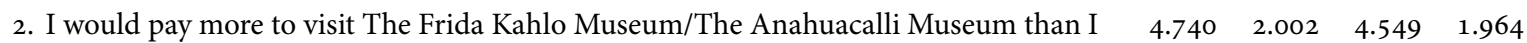
would pay to visit other tourist attractions of Mexico City

Notes Column headings are as follows: (1) mean, (2) standard deviation. ${ }^{\star}$ Dropped during the estimation of the measurement model.

(1) the process of the invariance assessment, (2) the specification of compositional invariance assessment, and (3) the evaluation of equal means and variances (Rasoolimanesh et al., 2017) (Table 6).

\section{Structural Model and Multi-Group Evaluation}

$R^{2}$ was evaluated to measure the model's explanatory power (Hair et al., 2014) and all dependent constructs were higher than o.10 (Falk \& Miller, 1992), reporting substantial and moderate coefficients (Cohen, 1988).
Likewise, positive Stone-Geisser's Q2 were obtained using blindfolding (Henseler et al., 2009), presenting moderate values (Table 7 ).

Table 8 presents the three following different results regarding: (1) the structural model and hypotheses analyses (5,00o bootstrap resamples and 5,00o permutations), (2) Henseler's MGA (Henseler et al., 2009), and (3) the permutation test (Chin \& Dibbern, 2010). Henseler's MGA compares group bootstrap estimates from each bootstrap sample, where the $p$-value that is 
Table 3 Reliability and Convergent Validity of the Final Measurement Model

\begin{tabular}{|c|c|c|c|c|c|c|c|c|c|c|c|c|c|}
\hline \multirow[t]{2}{*}{ Factor } & \multirow[t]{2}{*}{ Indic. } & \multicolumn{6}{|c|}{ Frida Kahlo Museum } & \multicolumn{6}{|c|}{ Anahuacalli Museum } \\
\hline & & (1) & (2) & (3) & (4) & (5) & (6) & (1) & (2) & (3) & (4) & (5) & (6) \\
\hline \multirow[t]{3}{*}{ Museum image } & MI1 & 0.773 & 16,609 & 0.641 & 0.644 & 0.806 & 0.581 & 0.866 & 30,335 & 0.769 & 0.780 & 0.866 & 0.684 \\
\hline & MI2 & 0.724 & 14,106 & & & & & 0.778 & 11,355 & & & & \\
\hline & MI4 & 0.788 & 19,199 & 0.766 & 0.781 & 0.851 & 0.590 & 0.835 & 26,791 & & & & \\
\hline \multirow{4}{*}{$\begin{array}{l}\text { Museum } \\
\text { satisfaction }\end{array}$} & MS 1 & 0.706 & 13,646 & & & & & 0.811 & 18,721 & 0.855 & 0.862 & 0.902 & 0.698 \\
\hline & MS 2 & 0.768 & 18,054 & & & & & 0.806 & 16,663 & & & & \\
\hline & MS 3 & 0.732 & 16,205 & & & & & 0.837 & 24,908 & & & & \\
\hline & MS 4 & 0.858 & 39,435 & & & & & 0.885 & 33,654 & & & & \\
\hline \multirow[t]{5}{*}{ Museum шом } & MW 1 & 0.773 & 15,059 & 0.792 & 0.815 & 0.857 & 0.548 & 0.815 & 21,232 & 0.890 & 0.891 & 0.919 & 0.694 \\
\hline & MW 2 & 0.666 & 10,462 & & & & & 0.802 & 17,170 & & & & \\
\hline & MW 3 & 0.803 & 17,707 & & & & & 0.875 & 31,648 & & & & \\
\hline & MW 4 & 0.620 & 9,453 & & & & & 0.818 & 26,943 & & & & \\
\hline & MW 5 & 0.817 & 23,029 & & & & & 0.855 & 26,431 & & & & \\
\hline \multirow{2}{*}{$\begin{array}{l}\text { Willingness } \\
\text { to pay more }\end{array}$} & WPM 1 & 0.927 & 77,226 & 0.791 & 0.811 & 0.904 & 0.826 & 0.932 & 62,144 & 0.833 & 0.837 & 0.923 & 0.857 \\
\hline & WPM 2 & 0.890 & 44,272 & & & & & 0.920 & 58,080 & & & & \\
\hline
\end{tabular}

Notes Column headings are as follows: (1) standardized loading, (2) $t$-value (bootstrap), (3) CA, (4) rhoA, (5) CR, (6) AVE.

Table 4 Measurement Model Discriminant Validity: Frida Kahlo Museum

\begin{tabular}{lrrrr}
\hline Factor & 1 & 2 & 3 & 4 \\
\hline 1 Museum Image & 0.762 & 0.744 & 0.780 & 0.488 \\
2 Museum Satisfaction & 0.535 & 0.768 & 0.734 & 0.592 \\
3 Museum woM & 0.571 & 0.587 & 0.740 & 0.616 \\
4 Willing. to pay more & 0.359 & 0.465 & 0.496 & 0.909 \\
\hline
\end{tabular}

Notes Diagonal values are AvE square root, values below the diagonal are latent variable correlations, values above the diagonal are нтмт ratios.

less than 0.05 or above 0.95 indicates at the $5 \%$ level significant differences between specific path coefficients across two groups (Henseler et al., 2009; Sarstedt et al., 2011). The permutation test identifies differences at the $5 \%$ level of significance if the $p$-value is less than 0.05 .

The findings show that museum satisfaction has a positive and significant effect on museum wом in both museums (H1a; Frida Kahlo Museum $\beta=0.587$, $p<0.01$; Anahuacalli Museum $\beta=0.739, p<0.01$ ) and on visitors' willingness to pay more (H1b; Frida Kahlo
Table 5 Measurement Model Discriminant Validity: Anahuacalli Museum

\begin{tabular}{lrrrr}
\hline Factor & 1 & 2 & 3 & 4 \\
\hline 1 Museum Image & 0.827 & 0.766 & 0.716 & 0.483 \\
2 Museum Satisfaction & 0.631 & 0.835 & 0.841 & 0.584 \\
3 Museum woM & 0.592 & 0.739 & 0.833 & 0.573 \\
4 Willing. to pay more & 0.387 & 0.495 & 0.494 & 0.926 \\
\hline
\end{tabular}

Notes Diagonal values are AvE square root, values below the diagonal are latent variable correlations, values above the diagonal are нтмт ratios.

Museum $\beta=0.465, p<0.01$; Anahuacalli Museum $\beta=$ $0.495, p<0.01)$. In addition, the results present a positive and significant effect of museum image on museum satisfaction in both samples (H1b; Frida Kahlo Museum $\beta=0.535, p<0.01$; Anahuacalli Museum $\beta=$ $0.631, p<0.01)$.

The permutation method results reveal that there are no significant differences between the Frida Kahlo Museum and Anahuacalli Museum regarding the effects of museum satisfaction on museum wom and willingness to pay more ( $\mathrm{H} 1 \mathrm{a}$ and $\mathrm{H} 1 \mathrm{~b}$ ), and museum 
Table 6 Results of Invariance Measurement Testing Using Permutation

\begin{tabular}{|c|c|c|c|c|c|c|c|c|c|c|c|c|}
\hline \multirow[t]{2}{*}{ Constructs } & \multirow[t]{2}{*}{ (1) } & \multirow[t]{2}{*}{ (2) } & \multirow[t]{2}{*}{ (3) } & \multirow[t]{2}{*}{ (4) } & \multicolumn{4}{|c|}{ Equal mean assessment } & \multicolumn{4}{|c|}{ Equal variance assessment } \\
\hline & & & & & (5) & $(6)$ & (7) & $(8)$ & (5) & (6) & (7) & (8) \\
\hline Museum Image & Yes & 0.998 & 0.992 & Yes & 0.481 & -0.170 & 0.178 & No & $-1,127$ & -0.578 & 0.590 & Yes \\
\hline Museum Satisfaction & Yes & 0.999 & 0.997 & Yes & 0.260 & -0.170 & 0.180 & No & -0.568 & -0.563 & 0.585 & No \\
\hline Museum wом & Yes & 0.997 & 0.997 & Yes & 0.329 & -0.175 & 0.176 & No & -0.713 & -0.496 & 0.525 & No \\
\hline Willing. to pay more & Yes & 1,000 & 0.998 & Yes & 0.043 & -0.175 & 0.173 & Yes & 0.047 & -0.217 & 0.233 & Yes \\
\hline
\end{tabular}

Notes Column headings are as follows: (1) configural invariance (same algorithms for both groups), (2-3) compositional invariance (correlation =1), (2) $\mathrm{C}=1,(3) 5 \%$ quantile, (4) partial measurement invariance established, (5) differences, (6) lower confidence interval, (7) upper confidence interval, (8) equal.

Table 7 Evaluation of the Estimated Models

\begin{tabular}{lcccccc}
\hline Concept & \multicolumn{2}{c}{ Frida Kahlo } & & \multicolumn{2}{c}{ Anahuacalli } \\
\cline { 2 - 3 } & $R^{2}$ & $Q^{2}$ & & $R^{2}$ & $Q^{2}$ \\
\hline Museum Satisfaction & 0.286 & 0.151 & & 0.398 & 0.247 \\
Museum woM & 0.345 & 0.166 & & 0.547 & 0.349 \\
Willigness to pay more & 0.216 & 0.167 & & 0.245 & 0.199 \\
\hline
\end{tabular}

image on museum satisfaction ( $\mathrm{H} 2)$. However, Henseler's MGA spots a slight difference between the two museums in the relationship between museum satisfaction and museum wом (H1a) $(p$-value $=0.958, p$ $<0.05$ ). Henseler's MGA and the permutation method techniques relatedly endorse the significance and nonsignificance of the differences, posing a multi-method confirmation of the findings.

\section{Discussion and Implications}

This research adds value to prior tourism studies by examining the direct impacts of: (1) museum satisfaction on museum WOM and WPM, and (2) museum image on museum satisfaction in two samples, namely Anahuacalli and Frida Kahlo visitors. In this way, this study has examined these different linkages in the two museums in order to pinpoint interesting generalizations in this industry.

The empirical findings show that museum satisfaction has a meaningful and positive effect on museum wом (H1a), as we expected. Although a controversy appeared recently when Trinh and Ryan (2013) concluded that there was an insignificant effect of museum satisfaction on museum wом in the case of a Viet- namese museum, the results of this study corroborate previous findings (Camarero \& Garrido, 2011; Harrison \& Shaw, 2004). In addition, we compared these linkages between the Frida Kahlo and Anahuacalli museums. Interestingly, Henseler's MG A results presented a difference between the two museums in this relationship. Although the effect sizes of both linkages are significant, the Anahuacalli museum case presents a higher influence of museum satisfaction on museum wom. As Table 2 presents, Frida Kahlo respondents valued to a slightly higher extent museum satisfaction and museum wом than Anahuacalli visitors.

The result of this linkage is not due to respondents' evaluation of these dimensions. This difference could be explained by the fact that Anahuacalli respondents might be considering that the museum is not so wellknown and are more willing to spread the word among their relatives and friends than in the other case, as Frida Kahlo has worldwide popularity as a Mexican cultural icon (Aragón, 2014; Dosamantes-Beaudry, 2002; Franco, 1991).

The results confirm the conclusions made by Bigné et al. (2008) that museum satisfaction can positively impact museum WPM ( $\mathrm{H1}$ b), and confirms the results conducted in hospitality studies (Barsky \& Nash, 2002; Ladhari et al., 2008; Lee et al., 2010; Lin, 2016; Heung $\& \mathrm{Gu}, 2012)$. The findings of the MGA confirm there are no significant differences between the two museums, revealing the same size effects in both cases. Besides, as expected, museum image has a positive and significant effect on museum satisfaction ( $\mathrm{H} 2)$, which has been confirmed for the first time in the museum 
Table 8 Hypotheses Testing

\begin{tabular}{|c|c|c|c|c|c|c|c|c|c|c|}
\hline \multirow[t]{3}{*}{ (1) } & \multirow[t]{3}{*}{ Relationship } & \multicolumn{2}{|c|}{ Path coefficients } & \multicolumn{4}{|c|}{ Confidence interval (95\%) } & \multirow[t]{3}{*}{ (2) } & \multicolumn{2}{|c|}{$p$-value difference $\dagger$} \\
\hline & & \multirow[t]{2}{*}{ (3) } & \multirow[t]{2}{*}{ (4) } & \multicolumn{2}{|c|}{ (3) } & \multicolumn{2}{|c|}{ (4) } & & (3) & (4) \\
\hline & & & & Lower & Upper & Lower & Upper & & & \\
\hline H1a & $\begin{array}{l}\text { Museum Satisfaction } \rightarrow \\
\text { Museum wom }\end{array}$ & $0.587^{* * *}$ & $0.739^{\star * *}$ & 0.459 & 0.687 & 0.590 & 0.833 & -0.152 & $0.958^{\star *}$ & 0.111 \\
\hline $\mathrm{H} 1 \mathrm{~b}$ & $\begin{array}{l}\text { Museum Satisfaction } \rightarrow \\
\text { Willingness to pay more }\end{array}$ & $0.465^{* * *}$ & $0.495^{\star * *}$ & 0.369 & 0.550 & 0.368 & 0.599 & -0.030 & 0.662 & 0.687 \\
\hline $\mathrm{H} 2$ & $\begin{array}{l}\text { Museum Image } \rightarrow \\
\text { Museum Satisfaction }\end{array}$ & $0.535^{* * *}$ & $0.631^{* * *}$ & 0.427 & 0.635 & 0.459 & 0.752 & -0.096 & 0.848 & 0.418 \\
\hline
\end{tabular}

Notes Column headings are as follows: (1) hypothesis, (2) path coefficient difference, (3) Frida Kahlo Museum, (4) Anahuacalli Museum, (5) Henseler's MGA, (6) permutation test. ${ }^{\star * *} p<0.01,{ }^{\star *} p<0.05,{ }^{\star} p<0.10 . \dagger$ two-tailed.

industry but was already concluded in tourism studies (Assaker et al., 2011; Chi \& Qu, 2008; Loi et al., 2017; Prayag, 2009; Wang \& Hsu, 2010). The MGA findings also confirm there are no significant differences between the two museums, and the results present the same size effects in both samples.

This study provides several theoretical implications related to museum satisfaction, WOM, WPM and image. First, few museum scholars have examined the impacts of visitors' satisfaction on their behavioural outcomes, wom and wTP (Bigné et al., 2008; Camarero \& Garrido, 2011; Harrison \& Shaw, 2004; Trinh \& Ryan, 2013). Hence, the present research has proposed a model to assess these relationships and the effect of museum image on satisfaction, which has been analysed for the first time in the museum industry. Second, the MGA results have proved that there are no significant differences between museum satisfaction and museum WPM, and between museum image and museum satisfaction, which are interesting findings for the future generalization of the results. In addition, Henseler's MGA results present a difference in the relationship between museum satisfaction and museum WоM, but the PLS-SEM results present both linkages as significant and positive. Hence, these findings extend the generalization of the results. Third, this research contributes not only to museum management literature, but also to tourism research, as it has examined these effects also considering two samples in an MGA approach.

The present study also draws managerial attention to numerous aspects for marketing managers and staff responsible for measuring visitors' satisfaction in museums. First, it has been concluded that visitors' satisfaction positively and significantly influences wом. As шом has been stated as a driver of museum visiting (Hausmann, 2012), it would be interesting to promote communication actions that boost this wom while visitors enjoy the museum experience. Museums could use ambient marketing strategies that are focused on increasing the number of photos shared by visitors in social media, following some of the actions developed by the Museum of Art of Sao Paolo or the Museum of Ice Cream.

Second, it has been proved that satisfaction has a positive and significant effect on W P M. Event though it has been suggested that visitors tend to perceive museums as free of charge or inexpensive entertainment options, especially when these organizations receive public support, it has been concluded that satisfied visitors are predisposed to pay more (Brida et al., 2016; Bigné et al., 2008). Hence, investment in the creation of a hitech edutainment service experience could make museums more competitive in the current Candy Crush and Netflix marketplace. For instance, museums could benefit from the Pokémon Go fever by positioning a market-adjusted image, and increasing their efforts to fulfil the needs of this segment (by placing poskètops, promoting a photocall event, etc.), which would likely improve their W PM.

Third, it has been pinpointed that a well-managed positive image will lead to visitors' satisfaction. In the 
light of the results, it is suggested that managers conduct a specific study for their museums to discover the different components that motivate a positive image for each of their market segments. This will help them improve their promotion strategies by selecting the adequate actions for each segment (Moreno-Gil \& Ritchie, 2009).

\section{Limitations and Future Research Lines}

Scholars are encouraged to encompass the results by bearing in mind the limitations of this research. First, this study has not considered the control variable of first-time or repeated visitors, or other educational or socio-economic factors that would have added interesting insights for the proposed model, as other scholars have previously proposed in related contexts (Beerli-Palacio \& Martín-Santana, 2017; Del Chiappa et al., 2013; Han \& Hyun, 2017). Second, the samples of visitors are of two Mexican museums that have the same management team, which has improved the sample collection but could have led to bias. Although the MGA comparison has presented similar outcomes that allow the generalization of the findings, it would be noteworthy to repeat this study in different museums.

\section{Acknowledgments}

The authors would like to thank the Frida Kahlo and Diego Rivera Anahuacalli museum team for their support, and especially the Directors of both museums, Hilda Trujillo, and Ximena Jordán.

\section{References}

Agyeiwaah, E., Adongo, R., Dimache, A., \& Wondirad, A. (2016). Make a customer, not a sale: Tourist satisfaction in Hong Kong. Tourism Management, 57, 68-79.

Aragón, A. F. (2014). Uninhabited dresses: Frida Kahlo, from icon of Mexico to fashion muse. Fashion Theory, 18(5), 517-549.

Assaker, G., Vinzi, V. E., \& O'Connor, P. (2011). Examining the effect of novelty seeking, satisfaction, and destination image on tourists' return pattern: A two factor, nonlinear latent growth model. Tourism Management, 32(4), 890-901.

Babin, B. J., Lee, Y.-K., Kim, E.-J., \& Griffin, M. (2005). Modeling consumer satisfaction and word-of-mouth: Restau- rant patronage in Korea. Journal of Services Marketing, 19(3), 133-139.

Barsky, J., \& Nash, L. (2002). Evoking emotion: Affective keys to hotel loyalty. Cornell Hotel and Restaurant Administration Quarterly, 43(1), 39-46.

Beerli-Palacio, A., \& Martín-Santana, J. D. (2004). Tourists' characteristics and the perceived image of tourist destinations: A quantitative analysis, a case study of Lanzarote, Spain. Tourism Management, 25(5), 623-636.

Beerli-Palacio, A., \& Martín-Santana, J. D. (2017). How does confirmation of motivations influence on the pre- and post-visit change of image of a destination? European Journal of Management and Business Economics, 26(2), 238-251.

Bigné, J. E., Andreu, L., \& Gnoth, J. (2005). The theme park experience: An analysis of pleasure, arousal and satisfaction. Tourism Management, 26(6), 833-844.

Bigné, E., Mattila, A. S., \& Andreu, L. (2008). The impact of experiential consumption cognitions and emotions on behavioural intentions. Journal of Services Marketing, 22(4), 303-315.

Brida, J. G., Meleddu, M., \& Pulina, M. (2016). Understanding museum visitors' experience: A comparative study. Journal of Cultural Heritage Management and Sustainable Development, 6(1), 47-71.

Burton, C., Louviere, J., \& Young, L. (2009). Retaining the visitor, enhancing the experience: Identifying attributes of choice in repeat museum visitation. International Journal of Nonprofit and Voluntary Sector Marketing, 14(1), 21-34.

Camarero, C., \& Garrido, M. J. (2011). Strengthening members' relationships through cultural activities in museums. Journal of Leisure Research, 43(4), 560-588.

Campón-Cerro, A. M., Hernandez-Mogollón, J. M., \& Alves, H. (2017). Sustainable improvement of competitiveness in rural tourism destinations: The quest for tourist loyalty in Spain. Journal of Destination Marketing and Management, 6(3), 252-266.

Carey, S., Davidson, L., \& Sahli, M. (2012). Capital city museums and tourism flows: An empirical study of the museum of New Zealand Te Papa Tongarewa. International Journal of Tourism Research, 15(6), 554-569.

Cevdet, M., \& Erkut, B. (2015). Cultural tourism in Istanbul: The mediation effect of tourist experience and satisfaction on the relationship between involvement and recommendation intention. Journal of Destination Marketing \& Management, 4(4), 213-222.

Chi, C. G. Q., \& Qu, H. (2008). Examining the structural relationships of destination image, tourist satisfaction and 
destination loyalty: An integrated approach. Tourism Management, 29(4), 624-636.

Chin, W. W., \& Dibbern, J. (2010). A permutation based procedure for multi-group PLS analysis: Results of tests of differences on simulated data and a cross-cultural analysis of the sourcing of information system services between Germany and the Us A. In E. V. Vinzi, W. W. Chin, J. Henseler, \& H. Wang (Eds.), Handbook of partial least Squares: Concepts, methods and applications (pp. 171193). Springer.

Choi, A. S., Ritchie, B. W., Papandrea, F., \& Bennet, J. (2010). Economic valuation of cultural heritage sites: A choice modelling approach. Tourism Management, 31(2), 213220.

Cohen, J. (1988). Statistical power analysis for the behavioural sciences. Lawrence Erlbaum.

Confente, I. (2015). Twenty-five years of word-of-mouth studies: A critical review of tourism research. International Journal of Tourism Research, 17(6), 613-624.

Del Bosque, I. R., \& San Martin, H. (2008). Tourist satisfaction: A cognitive-affective model. Annals of Tourism Research, 35(2), 551-573.

Del Chiappa, G., Andreu, L., \& Gallarza, M. G. (2014). Emotions and visitors' satisfaction at a museum. International Journal of Culture, Tourism and Hospitality Research, 8(4), 420-443.

Del Chiappa, G., Ladu, M. G., Meleddu, M., \& Pulina, M. (2013). Investigating the degree of visitors' satisfaction at a museum. Journal of Tourism and Hospitality Research, 24(1), 52-62.

DiMaggio, P. J. (1985). When the profit is quality: Cultural institutions in the marketplace. Museum News, 63(5), 2835 .

Dosamantes-Beaudry, I. (2002). Frida Kahlo: The creation of a cultural icon. The Arts in Psychotherapy, 29(1), 3-12.

Evrard, Y., \& Krebs, A. (2017). The authenticity of the museum experience in the digital age: The case of the Louvre. Journal of Cultural Economics, 42(2). https://doi.org/ 10.1007/s10824-017-9309-X

Falk, R. F., \& Miller, N. B. (1992). A primer for soft modelling. University of Akron Press.

Faul, F., Erdfelder, E., Lang, A. G., \& Buchner, A. (2007). $\mathrm{G}^{\star}$ Power 3: A flexible statistical power analysis program for the social, behavioural, and biomedical sciences. Behaviour Research Methods, 39(2), 175-191.

Ferrari, G., Mondéjar-Jiménez, J., \& Secondi, L. (2018). Tourists' expenditure in tuscany and its impact on the regional economic system. Journal of Cleaner Production, $171,1437-1446$.
Fornell, C., \& Larcker, D. (1981). Structural equation models with unobservable variables and measurement error. Journal of Marketing Research, 18(1), 39-50.

Fowler, F. J. (1984). Survey research methods. Sage.

Franco, J. (1991). 'Manhattan will be more exotic this fall:' The iconisation of Frida Kahlo. Women: A Cultural Review, 2(3), 220-227.

Frey, B. S., \& Steiner, L. (2012). Pay as you go: A new proposal for museum pricing. Museum Management and Curatorship, 27(3), 223-235.

Gázquez-Abad, J. C., Huertas-Garcia, R., Vazquez-Gomez, M. D., \& Casas Romeo, A. (2014). Drivers of sustainability strategies in Spain's wine tourism industry. Cornell Hospitality Quarterly, 56(1), 106-117.

Hair, J. F., Ringle, C., \& Sarstedt, M. (2011). PL S-SE M: Indeed a silver bullet. Journal of Marketing Theory and Practice, 19(2), 139-152.

Hair, J. F., Hult, G. T. M., Ringle, C., \& Sarstedt, M. (2014). A primer on Partial Least Squares Structural Equation Modelling (PLS-SEM). Sage.

Hair, J. F., Sarstedt, M., Matthews, L., \& Ringle, C. M. (2016). Identifying and treating unobserved heterogeneity with FIMIX-PLS: Part I - method. European Business Review, $28(1), 63-76$.

Han, H., \& Hyun, S. S. (2017). Key factors maximizing art museum visitors' satisfaction, commitment, and postpurchase intentions. Asia Pacific Journal of Tourism Research, 22(8), 834-849.

Harrison, J. (1997). Museums and touristic expectations. Annals of Tourism Research, 24(1), 23-40.

Harrison, P., \& Shaw, R. (2004). Consumer satisfaction and post-purchase intentions: An exploratory study of museum visitors. International Journal of Arts Management, 6(2), 23-32.

Hausmann, A. (2012). The importance of word of mouth for museums: An analytical framework. International Journal of Arts Management, 14(3), 32-43.

Henseler, J., Ringle, C. M., \& Sarstedt, M. (2015). A new criterion for assessing discriminant validity in variancebased structural equation modelling. Journal of the Academy of Marketing Science, 43(1), 115-135.

Henseler, J., Ringle, C. M., \& Sarstedt, M. (2016). Testing measurement invariance of composites using Partial Least Squares. International Marketing Review, 33(3), 405-431.

Henseler, J., Ringle, C. M., \& Sinkovics, R. R. (2009). The use of partial least squares path modelling in international marketing. Advances in International Marketing, 20(1), 277-320. 
Heung, V. C. S., \& Gu, T. (2012). Influence of restaurant atmospherics on patron satisfaction and behavioural intentions. International Journal of Hospitality Management, 31(4), 1167-1177.

Hume, M., Mort, G., \& Winzar, H. (2007). Exploring repurchase intention in a performing arts context: Who comes? And why do they come back? International Journal of Nonprofit and Voluntary Sector Marketing, 12(2), 135-148.

Kim, K., Gursoy, D., \& Lee, S. B. (2006). The impact of the 2002 World Cup on South Korea: Comparisons of preand post-games. Tourism Management, 27(1), 86-96.

Kim, K., Hallab, Z., \& Kim, J. N. (2012). The moderating effect of travel experience in a destination on the relationship between the destination image and the intention to revisit. Journal of Hospitality Marketing Management, 21(5), 486-505.

Kim, S. S., Lee, H., \& Chon, K. S. (2010). Segmentation of different types of hallyut ourists using a multinomial model and its marketing implications. Journal of Hospitality \& Tourism Research, 34(3), 341-363.

Kim, T. T., Kim, W. G., \& Kim, H. B. (2009). The effects of perceived justice on recovery satisfaction, trust, wordof-mouth, and revisit intention in upscale hotels. Tourism Management, 30(1), 51-62.

Kuikka, A., \& Laukkanen, T. (2012). Brand loyalty and the role of hedonic value. Journal of Product \& Brand Management, 21(7), 529-537.

Ladhari, R., Brun, I., \& Morales, M. (2008). Determinants of dining satisfaction and post-dining behavioural intentions. International Journal of Hospitality Management, 27(4), 563-573.

Lee, J. S., Hsu, L. T., Han, H., \& Kim, Y. (2010). Understanding how consumers view Green hotels: How a hotel's green image can influence behavioural intentions. Journal of Sustainable Tourism, 18(7), 901-914.

Lee, T. H. (2013). Influence analysis of community resident support for sustainable tourism development. Tourism Management, 34, 37-46.

Leung, D., Law, R., \& Lee, H. A. (2011). The perceived destination image of Hong Kong on Ctrip.com. International Journal of Tourism Research, 13(2), 124-140.

Lin, I. Y. (2016). Effects of visual servicescape aesthetics comprehension and appreciation on consumer experience. Journal of Services Marketing, 30(7), 692-712.

Liu, C. R., Liu, H. K., \& Lin, W. R. (2013). Constructing customer-based museums brand equity model: The mediating role of brand value. International Journal of Tourism Research, 17(3), 229-238.
Loi, L. T. I., So, A. S. I., Lo, I. S., \& Fong, L. H. N. (2017). Does the quality of tourist shuttles influence revisit intention through destination image and satisfaction? The case of Macao. Journal of Hospitality and Tourism Management, 32, 115-123.

Martínez, E., \& Pina, J. M. (2009). Modelling the brand extensions' influence on brand image. Journal of Business Research, 62(1), 50-60.

Mason, M. C., \& Paggiaro, A. (2012). Investigating the role of festival scape in culinary tourism: The case of food and wine events. Tourism Management, 33(6), 1329-1336.

McIntyre, C. (2009). Museum and art gallery experience space characteristics: An entertaining show or a contemplative bathe? International Journal of Tourism Research, 11(2), 155-170.

McLean, F. (1994). Services marketing: The case of museums. The Service Industries Journal, 14(2), 190-203.

Min, K. S., Martin, D., \& Jung, J. M. (2013). Designing advertising campaigns for destinations with mixed images: Using visitor campaign goal messages to motivate visitors. Journal of Business Research, 66(6), 759-764.

Molinillo, S., Liebana-Cabanillas, F., Anaya-Sanchez, F., \& Buhalis, D. (2018). D MO online platforms: Image and intention to visit. Tourism Management, 65(C), 116-130.

Mondéjar-Jiménez, J. A., García-Centeno, M. C., MínguezSalido, R., Mondéjar-Jiménez, J., \& Cordente-Rodríguez, M. (2010). Cultural tourism, using a multicriteria analysis: Spanish world heritage cities. International Journal of Management \& Information Systems, 14(4), 35-43.

Moreno-Gil, S., \& Ritchie, J. R. B. (2009). Understanding the museum image formation process: A comparison of residents and tourists. Journal of Travel Research, 47(4), 480493.

Ober-Heilig, N., Bekmeier-Feuerhahn, S., \& Sikkenga, J. (2014). Enhancing museum brands with experiential design to attract low-involvement visitors. Arts Marketing: An International Journal, 4(1/2), 67-86.

Plaza, B. (2010) Valuing museums as economic engines: Willingness to pay or discounting of cash-flows? Journal of Cultural Heritage, 11(2), 155-162

Podsakoff, P. M., MacKenzie, S. B., Lee, J. Y., \& Podsakoff, N. P. (2003). Common method biases in behavioural research: A critical review of the literature and recommended remedies. Journal of Applied Psychology, 88(5), 879-903.

Pop, I. L., \& Borza, A. (2016). Factors influencing museum sustainability and indicators for museum sustainability measurement. Sustainability, 8(1), 101-123.

Prayag, G. (2009). Tourists' evaluations of destination im- 
age, satisfaction, and future behavioural intentions: The case of Mauritius. Journal of Travel \& Tourism Marketing, 26(8), 836-853.

Prebensen, N., Skallerud, K., \& Chen, J. S. (2010). Tourist motivation with sun and sand destinations: Satisfaction and the wom-effect. Journal of Travel \& Tourism Marketing, $27(8), 858-873$.

Rasoolimanesh, S. M., Ringle, C., Jaafar, M., \& Ramayah, T. (2017). Urban vs. rural destinations: Residents' perceptions, community participation and support for tourism development. Tourism Management, 6o(4), 147-158.

Rasoolimanesh, S. M., Roldán, J. L., Jaafar, M., \& Ramayah, T. (2016). Factors influencing residents' perceptions toward tourism development: Differences across rural and urban world heritage sites. Journal of Travel Research, 56(6), 760-775.

Recuero, N., Blasco, M. F., \& San-Martin, S. (2017). How can European museums reach sustainability? Tourism Review, 72(3), 303-318.

Rentschler, R., Hede, A.-M., \& White, T. R. (2007). Museum pricing: Challenges to theory development and practice. International Journal of Nonprofit and Voluntary Sector Marketing, 12(2), 163-173.

Ringle, C. M., Wende, S., \& Becker, J.-M. (2015). SmartpLs 3 (Version 3.2.7). SmartPLs. http://www.smartpls.com.

Rosenberg, M. J., Hovland, C. J., McGuire, W., Abelson, R. P., \& Brehm, J. W. (1960). Attitude organization and change: An analysis of consistency among attitude components. Yale University Press.

Sarstedt, M., Henseler, J., \& Ringle, C. (2011). Multigroup analysis in Partial Least Squares (PLS) path modelling: Alternative methods and empirical results. Advances in International Marketing, 22(1), 195-218.

Secondi, L., Meseguer-Santamaría, M. L., Mondéjar-Jiménez, J., \& Vargas-Vargas, M. (2011). Influence of tourist sector structure on motivations of heritage tourists. The Service Industries Journal, 31(10), 1659-1668.

Sharifi-Tehrani, M., Verbic, M., \& Chung, J. Y. (2013). An analysis of adopting dual pricing for museums: The case of the national museum of Iran. Annals of Tourism Research, 43, 58-80.

Sheng, J., \& Lo, A. (2010). Evaluating the tourism potential of public museums in Hangzhou: A supply-side perspective. Journal of Travel \& Tourism Marketing, 27(3), 287305.

Simpson, P. M., \& Siguaw, J. (2008). Destination word of mouth: The role of traveller type, residents, and identity salience. Journal of Travel Research, 47(2), 167-182.

Sinclair-Maragh, G. (2017). Demographic analysis of resi- dents' support for tourism development in Jamaica. Journal of Destination Marketing \& Management, 6(1), 5-12.

Sirakaya-Turk, E., Ekinci, Y., \& Martin, D. (2015). The efficacy of shopping value in predicting destination loyalty. Journal of Business Research, 68(9), 1878-1885.

Steiner, F. (1997). Optimal pricing of museum admission. Journal of Cultural Economics, 21(4), 307-333.

Stylianou-Lambert, T. (2011). Gazing from home: Cultural tourism and art museums. Annals of Tourism Research, 38(2), 403-421.

Stylos, N., Vassiliadis, C. A., Bellou, V., \& Andronikidis, A. (2016). Destination images, holistic images and personal normative beliefs: Predictors of intention to revisit a destination. Tourism Management, 53, 40-6o.

Teo, T. S. H., Srivastava, S. C., \& Jiang, L. (2008). Trust and electronic government success: An empirical study. Journal of Management Information Systems, 25(3), 99-132.

Throsby, D. (2003). Determining the value of cultural goods: How much (or how little) does contingent valuation tell us? Journal of Cultural Economics, 27(3), 275-285.

Tian-Cole, S., Crompton, J. L. \& Willson, V. L. (2002). An empirical investigation of the relationships between service quality, satisfaction and behavioral intentions among visitors to a wildlife refuge. Journal of Leisure Research, 34(1), 1-24.

Throsby, D., \& Withers, G. (1979). The economics of the performing arts. Edward Arnold Publishers.

Tohmo, T. (2004). Economic value of a local museum: Factors of willingness-to-pay. The Journal of Socio-Economics, 33(2), 229-240.

Trinh, T. T., \& Ryan, C. (2013). Museums, exhibits and visitor satisfaction: A study of the Cham Museum, Danang, Vietnam. Journal of Tourism and Cultural Change, 11(4), 239-263.

Tsaia, C.-T., \& Wang, Y.-C. (2017). Experiential value in branding food tourism. Journal of Destination Marketing \& Management 6(1), 56-65.

Vaughan, R. (2001). Images of a museum. Museum Management and Curatorship, 19(3), 253-268.

Vu, H. Q., Luo, J. M., Ye, B. H., Li, G., \& Law, R. (2018). Evaluating museum visitor experiences based on usergenerated travel photos. Journal of Travel \& Tourism Marketing, 35(4), 493-506.

Wang, C. Y., \& Hsu, M. K. (2010). The relationships of destination image, satisfaction, and behavioural intentions. Journal of Travel \& Tourism Marketing, 27(8), 829-843.

Wang, C.-Y., \& Wu, L.-W. (2011). Reference effects on revisit intention: Involvement as a moderator. Journal of Travel \& Tourism Marketing, 28(8), 817-827. 
Wang, T. L., Tran, P. T. K., \& Tran, V. T. (2017). Destination perceived quality, tourist satisfaction and word-ofmouth. Tourism Review, 72(4), 392-410.

Whang, H., Yong, S., \& Ko, E. (2016). Pop culture, destination images, and visit intentions: Theory and research on travel motivations of Chinese and Russian tourists. Journal of Business Research, 69(2), 631-641.

$\mathrm{Wu}, \mathrm{C}$. W. (2015). Foreign tourists' intentions in visiting leisure farms. Journal of Business Research, 68(4), 757762.

Wu, C. W. (2016) Destination loyalty modelling of the global tourism. Journal of Business Research, 69(6), 2213-2219.
Xu, F., \& Fox, D. (2014). Modelling attitudes to nature, tourism and sustainable development in national parks: A survey of visitors in China and the U K. Tourism Management, 45, 142-158.

Yamada, N., \& Fu, Y.-Y. (2012). Using the theory of planned behaviour to identify beliefs underlying visiting the Indiana State Museum. Journal of Travel \& Tourism Marketing, 29(2), 119-132.

Yuksel, A., Yuksel, F., \& Bilim, Y. (2010). Destination attachment: Effects on customer satisfaction and cognitive, affective and conative loyalty. Tourism Management, 31(2), 274-284. 


\section{Sodelovanje skupnosti pri trajnostni valorizaciji kulturne dediščine: primer občine Vrsar}

Kristina Afrić Rakitovac, Nataša Urošević in Nikola Vojnović

Trajnostni turizem predstavlja turizem, ki spoštuje prebivalce in obiskovalce, kulturno dediščino in okolje. Ponudi lahko ustrezne modele za trajnostno upravljanje kulturne dediščine in razvoj lokalnega gospodarstva. Sodelovanje skupnosti je eno temeljnih načel trajnostnega turizma. To načelo je del študija turizma že več kot tri desetletja in je bilo utemeljeno $\mathrm{z}$ različnimi metodološkimi pristopi in raziskavami. Namen tega prispevka je bil izpostaviti perspektive lokalne skupnosti glede trajnostne valorizacije kulturne in arheološke dediščine. Raziskava je bila izvedena v okviru ArchaeoCulTour, znanstvenega projekta, katerega glavni cilj je analizirati razvojni potencial arheološke dediščine skozi trajnostni turizem v Istrski županiji na Hrvaškem. V raziskavi je kot študija primera vključena občina Vrsar v zahodni Istri, tipična sredozemska turistična destinacija, za katero sta značilna množični turizem in velika sezonskost. Raziskava je pokazala, da prebivalci občine Vrsar delno podpirajo sedanji model razvoja turizma, ki se sooča $\mathrm{z}$ različnimi izzivi trajnosti in $\mathrm{s}$ številnimi infrastrukturnimi težavami. Prebivalci si želijo biti bolje informirani in bolj vključeni v proces načrtovanja turizma ter modelov participativnega upravljanja dediščine. Strinjajo se, da bi se lahko glavna trajnostna vprašanja izboljšala s trajnostno valorizacijo lokalnih kulturnih in naravnih virov $\mathrm{z}$ ustvarjanjem inovativnih izkušenj s turizmom, zato so zainteresirani za sodelovanje $\mathrm{v}$ tem postopku soustvarjanja.

Ključne besede: turistične destinacije, kulturna dediščina, trajnostni kulturni turizem, sodelovanje skupnosti

Academica Turistica, 14(1), 7-22

\section{Trajnostni razvoj otoške turistične destinacije: primer otoka Paga}

Aleksandra Krajnović, Ivica Zdrilić in Nikolina Miletić

Namen prispevka je raziskati vprašanje trajnostnega razvoja turizma na otoških destinacijah na primeru otoka Pag na Hrvaškem. Namen je bil ugotoviti obseg trajnostnega razvoja turizma na otoku Pag in odkriti dejavnike, ki nanj vplivajo. S prvotno raziskavo se želi ugotoviti, kakšna so mnenja in pogledi ključnih deležnikov turizma o trajnostnem turizmu na Pagu. Ključno raziskovalno vprašanje v prispevku je: Kateri model razvoja turizma je optimalen za trajnostni razvoj otoka Paga kot turistične destinacije? Uporabljeni sta bili metoda kvalitativne analize ter primarna raziskava, ki je združevala intervjuje s strokovnjaki in ankete. Poleg tega je bila opravljena primerjalna analiza rezultatov raziskav z uporabo intervjujev in rezultatov anketiranja. Raziskava je potekala v letu 2019 na otoku Pag. Intervjuji so se izvajali s ključnimi deležniki turizma na otoku pa tudi z uslužbencem Turistične skupnosti mesta Pag. Po empirični raziskavi je bilo ugotovljeno, da se trajnostni turizem na otoku Pag slabo razvija. Trajnostni razvoj turizma vključuje odgovorno upravljanje območja s poudarkom na naravni in kulturni dediščini, njegov namen pa je zadovoljiti potrebe turistov ter potrebe sedanjih in prihodnjih lokalnih skupnosti. Trajnost in trajnostni razvoj turizma, zlasti na otokih kot izredno krhkih geografskih, gospodarskih 
in družbeno-kulturnih enotah, sta še posebej pomembna. Pri tem je treba uporabiti celostni pristop.

Ključne besede: trajnostni turizem, množični turizem, trajnostna turistična destinacija, sezonskost, trajnostni turizem na otokih, otok Pag

Academica Turistica, 14(1), 23-37

\section{Družbena trajnost destinacije: povezovanje razvoja turizma s kakovostjo življenja prebivalcev}

Emil Juvan, Eva Podovšovnik, Miha Lesjak in Jasmina Jurgec

Turizem pozitivno prispeva h kakovosti življenja ( $\mathrm{k}$ zadovoljstvu z življenjem in čustvenemu počutju) potujoče populacije, vprašanje pa je, kako lahko prispeva h kakovosti življenja gostiteljske populacije. Kakovost življenja prebivalcev turistične destinacije je ključni cilj trajnostnega razvoja turizma, vsaj v kontekstu družbene trajnosti, hkrati pa kakovost življenja predstavlja tudi pomemben trženjski atribut turistične destinacije. Raziskave nakazujejo, da lahko preobsežen stik s turizmom znižuje kakovost življenja gostiteljev. Slaba kakovost življenja, tipično demonstrirana kot nizka stopnja zadovoljstva $\mathrm{z}$ življenjem in slabo čustveno počutje, vodi v razvoj protiturističnih prepričanj in zmanjša podporo lokalnega prebivalstva za razvoj turizma. Takšno stanje lahko resno ovira strateški razvoj turizma in njegovo izvajanje. Visoko razvit turizem predstavlja pomemben vir prihodkov za lokalno okolje, vendar lahko hkrati predstavlja tudi pomemben razlog visokih stroškov zagotavljanja kakovostnega bivanjskega okolja in dobrega počutja prebivalstva. Prispevek analizira povezavo med zadovoljstvom z življenjem in objektivno (stopnja razvoja turizma) ter subjektivno (zaznana interakcija s turisti). Rezultati kažejo, da ne stopnja razvoja turizma niti stopnja interakcije s turisti nista povezani z zadovoljstvom lokalnega prebivalstva z življenjem. Te ugotovitve postavljajo pod vprašaj prevladujočo predpostavko, da visoka stopnja turizma generično negativno vpliva na zadovoljstvo lokalnega prebivalstva z življenjem. Razprava vodi v spoznanje, da destinacije potrebujejo lastne kvantitativne (npr. obseg turizma) in kvalitativne (npr. narava stika s turisti) ocene o stopnji razvoja turizma, ki še zagotavlja kakovost življenja in dobro čustveno počutje lokalnega prebivalstva. To bo turističnim destinacijam omogočilo učinkovitejše doseganje pozitivnih družbenih učinkov turizma in družbeno trajnost. Ključne besede: trajnostni turizem, družbena trajnost, kakovost življenja, prebivalci, destinacija

Academica Turistica, 14(1), 39-52

\section{Stališča managerjev o razmerju med turizmom in podnebnimi spremembami: primer Republike Hrvaške}

Aleksandar Racz, Dora Smolčić Jurdana in Zvonimira Šverko Grdić

Ob predpostavki dvosmernega odnosa med podnebnimi spremembami in turizmom je zelo pomembno poznati prepričanja in stališča managerjev $\mathrm{v}$ turizmu. Raziskovanje teh prepričanj in stališč je bila ključna naloga te raziskave. Na prepričanja 
in stališča turističnih managerjev vplivajo različni dejavniki, kot so: sociodemografske značilnosti, zlasti spol, stopnja izobrazbe, delovna doba $v$ turističnem sektorju, članstvo v ekoloških nevladnih organizacijah ter prepričanja in stališča o podnebnih spremembah. Za preučitev mnenja managerjev so avtorji izvedli raziskavo, ki se je osredotočila na vse managerje, ki v Republiki Hrvaški upravljajo kategorizirane objekte glede na njihovo vrsto. Rezultati so pokazali pomembne razlike v prepričanjih in stališčih o medsebojnem vplivu podnebnih sprememb ter turističnih nastanitev. Ženske managerke, ki so končale terciarno izobrazbo, so članice ekoloških nevladnih organizacij in se imajo za aktivistke, ter tiste, ki imajo več let delovnih izkušenj, so izrazile močnejši prookoljski odnos in izkazale višjo raven ekološke zavesti.

Ključne besede: stališča, prepričanja, podnebne spremembe, management, turizem, destinacije

Academica Turistica, 14(1), 53-70

\section{Študija ovir za okoljsko trajnostne prakse v hotelskih podjetjih v Punjabu v Indiji: predhodne ugotovitve \\ Baljit Kaur}

Namen te primarne študije je bil raziskati kritične ovire okoljskih trajnostnih praks in podati predloge, kako jih premagati v kontekstu hotelskih podjetij. V študiji je bil uporabljen kvantitativni pristop k raziskovanju, vprašalnik pa je bil razvit s pomočjo temeljitega pregleda literature, analize vsebine in pilotne študije. Skupno je bilo zbranih 221 odgovorov managerjev in direktorjev iz skupaj 88 hotelov v Punjabu. Izmed poslanih anket je bilo 202 primernih za nadaljno obdelavo s pomočjo opisne statistike in Kendallovim W-testom. Rezultati so pokazali, da začetni stroški izvedbe, visoki stroški certificiranja, zapleten postopek certificiranja, pomanjkanje ozaveščenosti o konceptu, šibka zakonodaja, sprememba rutin in načina vodenja, obstoječa struktura, ki koncepta ne podpira, ter nizka zavezanost vodstva pomembno vplivajo na sprejetje in izvajanje okoljskih trajnostnih praks. Kendallov W-test je pri anketirancih pokazal statistično značilno strinjanje $\mathrm{z}$ omenjenimi ugotovitvami. $\mathrm{Na}$ podlagi rezultatov podajamo priporočila za premagovanje ovir za izvajanje okoljskih trajnostnih praks, tako npr. hotelska podjetja lahko začnejo z majhnimi pobudami, ki zahtevajo nizke začetne naložbe, lobiranje hotelov pri regionalnih hotelskih združenjih in vladi, da dobijo finančno podporo in razširjajo okoljsko komunikacijo med zaposlenimi, prav tako predlagamo metode spremljanja okolja in sheme nagrajevanja s strani vlade. Ta študija se je izvedla na majhnem geografskem območju, ki je sicer svetovno znana turistična destinacija, rezultati pa so skladni z ugotovitvami prejšnjih študij, ki so bile izvedene po vsem svetu. Tako predlagamo prihodnje študije na večjih geografskih območjih s primerjavo dveh ali več držav.

Ključne besede: hotelska podjetja, okoljsko trajnostne prakse, ovire, predlogi, Punjab, Indija

Academica Turistica, 14(1), 71-86 


\section{Kakovost podeželske destinacije: pristop obiskovalcev in prebivalcev}

Kateřina Mlejnková, Tomáš Dania in Ida Rašovská

Kakovost destinacije opredeljuje sklop številnih dejavnikov. Način vrednotenja teh dejavnikov je predmet stalnih raziskav. Eden od pristopov temelji na ocenjevanju zadovoljstva obiskovalcev in domačinov ter uporabi teh rezultatov za upravljanje kakovosti in trajnostnega razvoja destinacije. Pričujoči članek analizira podeželsko regijo na Češkem z IPA, tj. analiza pomena - izvedbe (angl. importance-performance analysis). S to analizo smo ovrednotili dejavnike, ki pomembno vplivajo na zadovoljstvo obiskovalcev in lokalnih prebivalcev. Identificirali smo več statistično značilnih razlik v dojemanju pomena dejavnikov med obiskovalci in domačini. Tako so npr. obiskovalci dejavnikoma prenatrpanost in prijazen sprejem s strani domačinov pripisali večji pomen kot domačini. Obe skupini se zavedata pomena trajnostnega turizma in kakovosti storitev. Rezultati kažejo, da v regiji obstajajo področja, potrebna izboljšav. Identificirana je bila glavna vrzel med zaznano ravnjo kakovosti storitve destinacije in pomembnostjo dejavnika. Na podlagi rezultatov so oblikovana priporočila za organizacijo destinacijskega menedžmenta.

Ključne besede: kakovost, domačini, obiskovalci, podeželska destinacija, IPA Academica Turistica, 14(1), 87-99

\section{Pripravljenost plačati več: iskanje odličnih muzejev}

Nuria Recuero Virto, María Francisca Blasco López in Juan Antonio Mondejar

Upravitelji muzejev svoja prizadevanja nenehno usmerjajo v ekonomsko upravičenost. To je postal ključni izziv, saj se ponudba atrakcij »izkustvene ekonomije « povečuje, obiskovalci pa iščejo konkurenčne izkušnje. Čeprav se navaja, da slika pove tisoč besed, je glavni cilj te raziskave ugotoviti, ali razmerje med podobo muzeja in zadovoljstvom obiskovalcev signifikantno in pozitivno vpliva na njihovo pripravljenost plačati več. Za izvedbo primerjave med več skupinami so bile uporabljene analiza $\mathrm{z}$ nedavno razvitim merjenjem invariantnosti kompozitov (angl. мІсом) in nove metode permutacije. Skupno je bilo pridobljenih 529 veljavnih odgovorov obiskovalcev muzeja. Zanimivo je, da so ugotovitve pokazale, da med obema muzejskima vzorcema ni bilo bistvenih razlik in da so bili vsi analizirani odnosi med sabo pozitivno povezani ter signifikantni. Podobna Henselerjeva raziskava med več skupinami je med dvema vzorcema obiskovalcev muzeja ugotovila majhno razliko $\mathrm{v}$ povezavi med zadovoljstvom obiskovalcev in njihovim ustnim oglaševanjem (angl. word-of-mouth). Ta raziskava predlaga večskupinsko primerjalno študijo, ki preučuje dva različna vzorca obiskovalcev dveh izrazito prepoznavnih mehiških muzejev, tako da ugotovitve prinašajo koristne napotke za akademsko in vodstveno sfero turistične industrije.

Ključne besede: večskupinska analiza, zadovoljstvo, podoba, pripravljenost plačati več, ustno oglaševanje

Academica Turistica, 14(1), 101-114 


\section{Instructions for Authors}

\section{Aim and Scope of the Journal}

Academica Turistica - Tourism and Innovation Journal (AT-TIJ) is a peer-reviewed journal that provides a forum for the dissemination of knowledge on tourism and innovation from a social sciences perspective. It especially welcomes contributions focusing on innovation in tourism and adaptation of innovations from other fields in tourism settings.

The journal welcomes both theoretical and applicative contributions and encourages authors to use various quantitative and qualitative research methodologies. Besides research articles, the journal also publishes review articles, commentaries, reviews of books and conference reports. Purely descriptive manuscripts which do not contribute to the development of knowledge are not considered suitable.

\section{General Guidelines and Policy of the Journal}

Manuscripts are accepted in both American and British English; however, consistency throughout the paper is expected. All manuscripts are subject to an initial editorial screening for adherence to the journal style, for anonymity, and for correct use of English. As a result of this your paper will be either accepted for further consideration or returned for revision. To avoid unnecessary errors you are strongly advised to have your manuscript proofread.

Manuscripts should be organized in the following order: title, abstract, keywords, main text, acknowledgements, references, and appendixes (as appropriate).

Reviewing. Each manuscript, meeting the technical standards and falling within the aims and scope of the journal, will be subject to double-blind review by two reviewers. Authors can propose up to two reviewers for revision of their work and also up to two reviewers they would like to avoid.

The referees are chosen by the Editorial Board. Assessments by the referees will be presented anonymously to the author and, in the case of substantial reservations, the article, with the list of corrections needed, will be returned to the author for correction. The corrected copy of the article with the list of corrections on a separate page should be returned to the Editorial Board.

Permissions. Authors wishing to include figures, tables, or text passages that have already been published elsewhere, are required to obtain permission from the copyright owner(s) and to include evidence that such permission has been granted when submitting their papers. Any material received without such evidence will be assumed to originate from the authors.

Submission declaration. Submission of a manuscript implies that it has not been published previously (except in the form of abstract or as part of a published lecture or academic thesis), that it is not under consideration for publication elsewhere, that its publication is approved by all its authors and tacitly or explicitly by the responsible authorities where the work was carried out. The corresponding author should ensure that all appropriate co-authors and no inappropriate co-authors are included on the paper, and that all coauthors have seen and approved the final version of the paper and have agreed to its submission for publication.

Conflict of interest. All authors are requested to disclose any actual or potential conflict of interest including any financial, personal or other relationships with other people or organizations within three years of beginning the submitted work that could inappropriately influence, or be perceived to influence, their work.

\section{Manuscript Preparation}

Manuscripts should be prepared according to the style prescribed by the Publication Manual of the American Psychological Association (American Psychological Association, 2020; see also http://www.apastyle.org).

Language and style. The first author is fully responsible for the language and style in the context of the instructions. A good scientific standard command of grammar and style is expected.

Text formatting. Please, use the automatic page numbering function to number the pages. Use tab stops or other commands for indents, not the space bar. Use the table function, not spreadsheets, to make tables. Use 
the equation editor or MathType for equations. Whenever possible, use the sI units (Système international d'unités).

The title page should include the title of the article (no more than 85 characters, including spaces), full name of the author(s), affiliation (institution name and address) of each author clearly identified; linked to each author by use of superscript numbers, corresponding author's full name, telephone, and e-mail address.

Abstract. The authors are obliged to prepare two abstracts - one in English and one (translated) in Slovene language. For foreign authors translation of the abstract into Slovene will be provided.

The content of the abstract should be structured into the following sections: purpose, methods, results, and conclusion. It should only contain the information that appears in the text as well. It should contain no reference to figures, tables and citations published in the main text, and should not exceed 250 words.

Beneath the abstract, the authors should supply appropriate keywords (3-6) in English and in Slovene. For foreign authors the translation of the abstract into Slovene will be provided.

The main text should contain a coherent and logical structure preferably following the IMRAD format (Introduction, Methods, Research [and] Discussion). However, other structures are also welcome (e.g. Introduction, Development and Conclusions) as long as the text maintains its logical structure and focus. Acknowledgments are optional.

The length of the articles should not exceed 9,000 words (including tables, figures, and references), double spaced, using Times New Roman font sized 12.

Tables. Each table should be submitted on a separate page in a Word document after References. Each table shall have a brief caption; explanatory matter should be in the footnotes below the table. The table shall contain means and the units of variation (SD, $\mathrm{SE}$, etc.) and must be free of nonsignificant decimal places. Abbreviations used in the tables must be consistent with those used in the text and figures. Definition symbols should be listed in the order of appearance, determined by reading horizontally across the table and should be identified by standard symbols. All tables should be numbered consecutively (Table 1, Table 2 , etc.).

Figures. Captions are required for all Figures and shall appear on a separate manuscript page, beneath table captions. Each figure should be saved as a separate file without captions and named as Figure 1, etc. Files should be submitted in ${ }^{*}$.tiff or ${ }^{*}$.jpeg format. Photographs should be saved at at least 300 dpi. Line art images should be saved at 1200 dpi. Lettering (symbols, letters, and numbers) should be between 8 and 9 points, with consistent spacing and alignment. Font face may be Serif (Minion) or Sans Serif (Myriad). Line width should be 0.5 point or greater. Any extra white or black space surrounding the image should be cropped. Ensure that subject-identifying information (i.e., faces, names, or any other identifying features) is cropped out or opaqued. Prior to publication, the author(s) should obtain all necessary authorizations for the publication of the illustrative matter and submit them to the Editorial Board. All figures should be numbered consecutively (Figure 1, Figure 2, etc.). The journal will be printed in black and white. If the paper contains graphs, we would appreciate that you also e-mail them in a separate Excel file.

\section{References}

References should be formatted according to the $\mathrm{Pu}$ blication Manual of the American Psychological Association (American Psychological Association, 2019).

The list of references should only include works that are cited in the text. Personal communications and unpublished works should only be mentioned in the text. References should be complete and contain all the authors that have been listed in the title of the original publication. If the author is unknown, start with the title of the work. If you are citing a work that is in print but has not yet been published, state all the data and instead of the publication year write 'in print.'

Reference list entries should be alphabetized by the last name of the first author of each work. Do not use footnotes or endnotes as a substitute for a reference list. Full titles of journals are required (not their abbreviations). 


\section{Citing References in Text}

One author. Tourism innovation specific is mentioned (Brooks, 2010). Thomas (1992) had concluded ...

Two authors. This result was later contradicted (Swarbrooke \& Horner, 2007). Price and Murphy (2000) pointed out...

Three or more authors. Wolchik et al. (1999) or (Wolchik et al., 1999).

If two references with three or more authors shorten to the same form, cite the surnames of the first author and of as many of the subsequent authors as necessary to distinguish the two references, followed by a coma and et al.

List several authors for the same thought or idea with separation by using a semicolon: (Kalthof et al., 1999; Biegern \& Roberts, 2005).

\section{Examples of Reference List}

Books

American Psychological Association. (2019). Publication manual of the American Psychological Association (7th ed.).

Swarbrooke, J., \& Horner, S. (2007). Consumer behaviour in tourism. Butterworth-Heinemann.

\section{Journals}

Laroche, M., Bergeron, J., \& Barbaro-Forleo, G. (2001). Targeting consumers who are willing to pay more for environmentally friendly products. Journal of Consumer Marketing, 18(6), 503-520.

Wolchik, S. A., West, S. G., Sandler, I. N., Tein, J.Y., Coatsworth, D., Lengua, L., ... Griffin, W. A. (2000). An experimental evaluation of theorybased mother and mother-child programs for children of divorce. Journal of Consulting and Clinical Psychology, 68, 843-856.

\section{Newspapers}

Brooks, A. (2010, 7 July). Building craze threatens to end Lanzarote's biosphere status. Independent. http://www.independent.co.uk/environment/ nature/building-craze-threatens-to-end -lanzarotes-biosphere-status-2020064.html

\section{Chapters in Books}

Poirier, R. A. (2001). A dynamic tourism development model in Tunisia: Policies and prospects. In Y. Aposotolopoulos, P. Loukissas, \& L. Leontidou (Eds.), Mediterranean tourism (pp. 197-210). Routledge.

\section{Conference Proceedings}

Price, G., \& Murphy, P. (2000). The relationship between ecotourism and sustainable development: A critical examination. In M. Ewen (Ed.), CAUTHE 200o: Peak performance in tourism and hospitality research; Proceedings of the Tenth Australian Tourism and Hospitality Research Conference (pp. 189202). La Trobe University.

\section{Paper Presentation}

Thomas, J. (1992, July). Tourism and the environment: An exploration of the willingness to pay of the average visitor [Paper presentation.] Tourism in Europe, Durham, England.

\section{Theses and Dissertations}

Sedmak, G. (2006). Pomen avtentičnosti turističnega proizvoda: primer destinacije Piran [Unpublished doctoral dissertation]. University of Ljubljana.

\section{Working Papers}

Salamon, L. M., Sokolowski, S. W., Haddock, M. A., \& Tice, H. S. (2013). The state of global civil society volunteering: Latest findings from the implementation of the UN nonprofitt handbook (Comparative Nonprofit Sector Working Paper No. 49). Johns Hopkins University.

\section{Web Pages}

Croatian Bureau of Statistics. (2001). Census of population, households and dwellings. http://www.dzs .hr/Eng/censuses/Census2001/census.htm

\section{Manuscript Submission}

The main manuscript document should be in Microsoft Word document format and the article should be submitted to http://academica.turistica.si/index.php/ AT-TIJ/about/submissions 



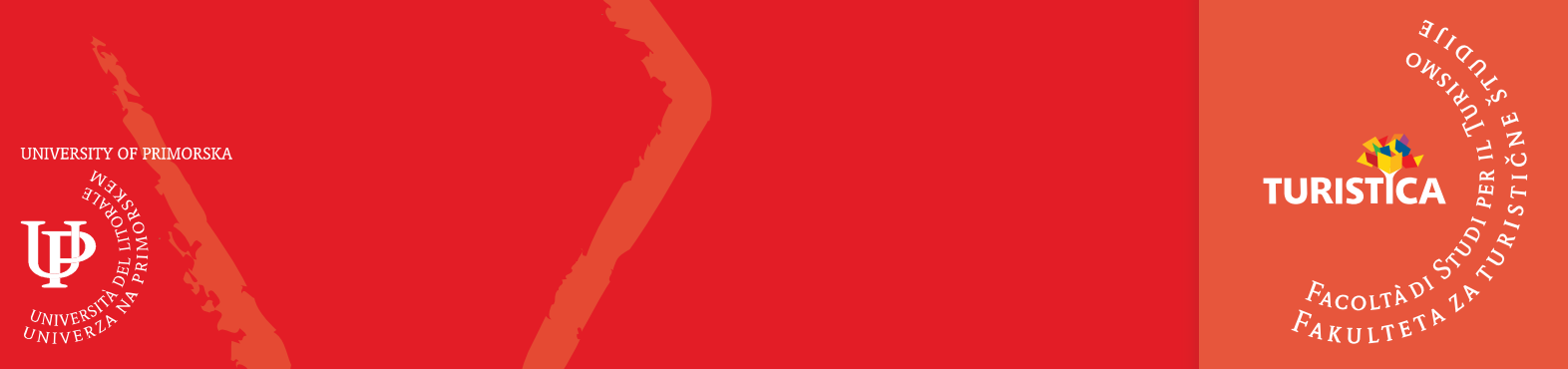